\title{
THE POTENTIAL OF THERMAL ENERGY STORAGE AS AN ENERGY RETROFIT MEASURE FOR HIGH-RISE RESIDENTIAL BUILDINGS IN CANADA
}

By

\author{
Shahrzad Soudian
}

BArch in Architectural Engineering, Qazvin Azad University, Iran, 2014

\author{
A thesis \\ presented to Ryerson University \\ in partial fulfillment of the \\ requirements for the degree of \\ Master of Applied Science \\ in the program of \\ Building Science
}

Toronto, Ontario, Canada, 2017

(C) Shahrzad Soudian 2017 


\section{AUTHOR'S DECLARATION}

I hereby declare that I am the sole author of this thesis. This is a true copy of the thesis, including any required final revisions, as accepted by my examiners.

I authorize Ryerson University to lend this thesis to other institutions or individuals for the purpose of scholarly research.

I further authorize Ryerson University to reproduce this thesis by photocopying or by other

means, in total or in part, at the request of other institutions or individuals for the purpose of scholarly research.

I understand that my thesis may be made electronically available to the public. 


\title{
THE POTENTIAL OF THERMAL ENERGY STORAGE AS AN ENERGY RETROFIT MEASURE FOR HIGH-RISE RESIDENTIAL BUILDINGS IN CANADA
}

Master of Applied Science in the program of Building Science, 2017

Shahrzad Soudian, Ryerson University

\begin{abstract}
High-rise apartments are a prominent type of residential buildings in Canadian cities. However, poor aging performance of existing apartments has led to high discomfort and energy consumption that must be addressed. Thermal energy storage is a potential energy retrofit measure that affects energy consumption by regulating radiant temperatures. The aim of this study is to evaluate the effectiveness of latent thermal energy storage using phase change materials (PCMs) integrated into walls and ceilings of apartment units. A composite PCM system comprised of two different PCM products with melting points of $21.7^{\circ} \mathrm{C}$ and $25^{\circ} \mathrm{C}$ is proposed and evaluated to provide a year-around thermal energy storage. A simulation analysis using Energy Plus is performed to investigate the impacts of the composite PCM system on indoor temperatures and energy use. An experimental study is conducted using two small scale test cells to monitor the performance of the PCM system in detail.
\end{abstract}




\section{Acknowledgments}

I would like to extend my sincere gratitude to my supervisor, Dr. Umberto Berardi for his continuous guidance, patience, and support, which allowed me to expand my knowledge and exercise my abilities in the field of Building Science. I was motivated every day to increase my efforts and work harder to reflect all that I have learned in my final work.

I express my appreciation to Dr. Ramani Ramakrishnan whose great advice and supervision assisted me in refining my final work. I must acknowledge the financial support provided by BC Housing as well as NSERC which made this research possible.

I wish to thank my parents who have supported me every single day of this journey and gave me the greatest inspiration to continue my education. I thank you for all the love you have given me and all the sacrifices you have made that brought me here. I thank my brother for his positive energy and good spirit that motivated me during this time.

Finally, many thanks to the Faculty of Building Science at Ryerson University that provided me with the greatest council and assistance throughout the past three years. I cherish my time at Ryerson University and am truly grateful for the great opportunity to be a part of this interdisciplinary program that allowed me to continue my path by bridging my two passions of Architecture and Sustainability. 


\section{Table of Contents}

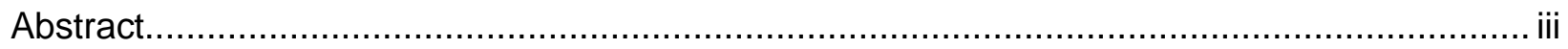

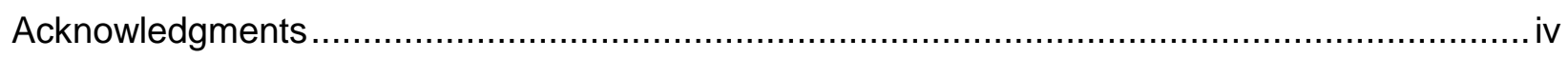

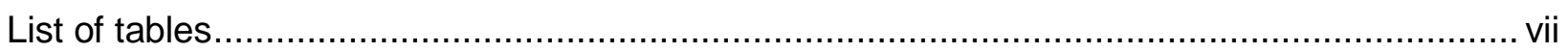

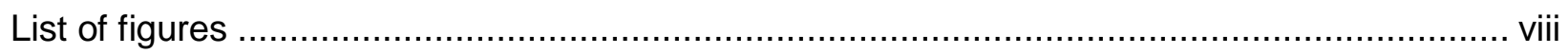

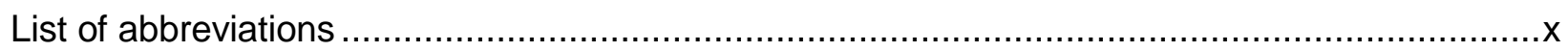

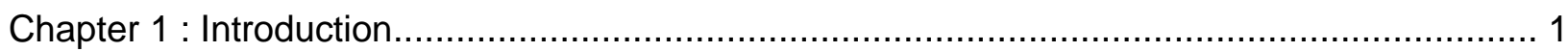

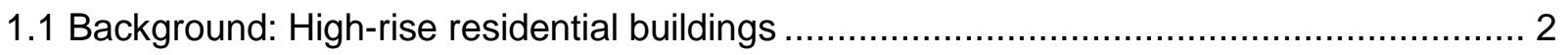

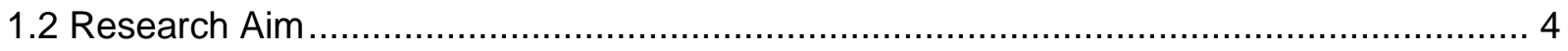

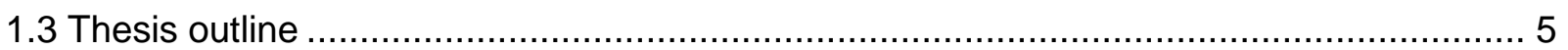

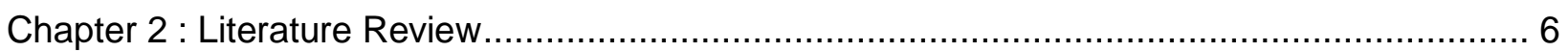

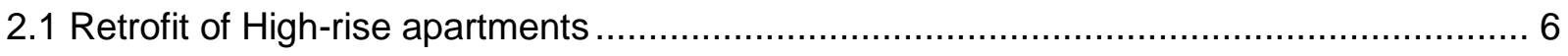

2.2 Thermal energy storage ................................................................................... 7

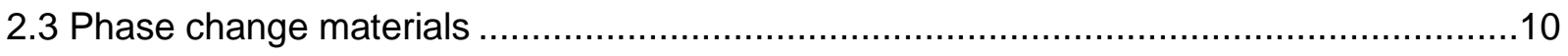

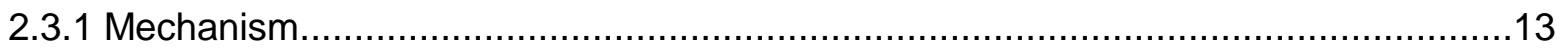

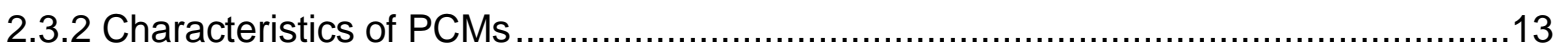

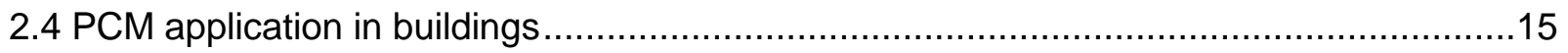

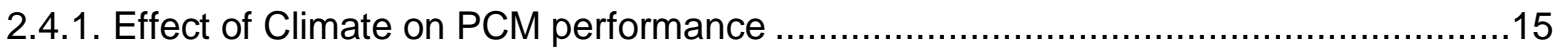

2.4.2. Positioning of PCM applications in buildings ..................................................17

2.4.3. Performance indicators for PCMs ................................................................. 17

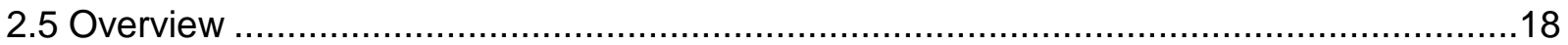

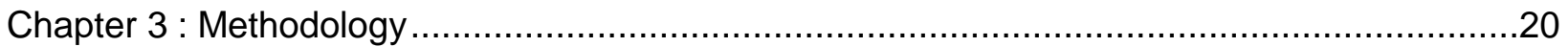

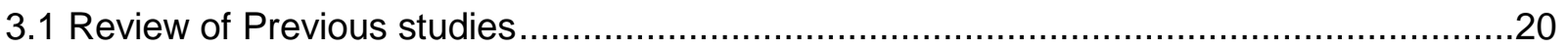

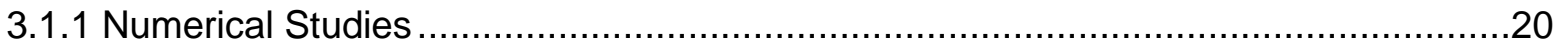

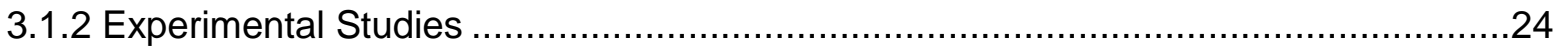

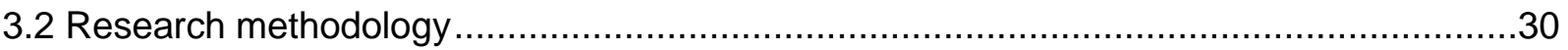

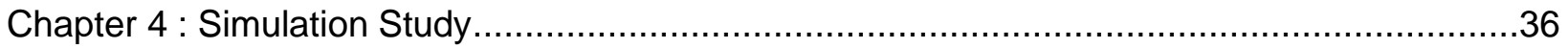

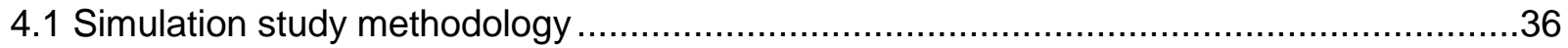

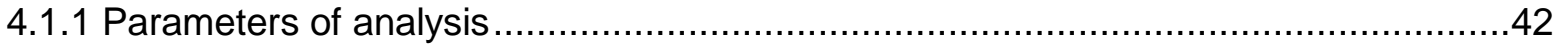

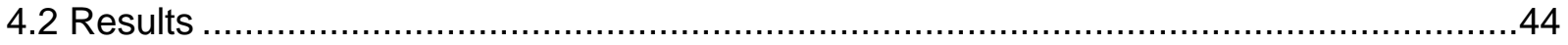

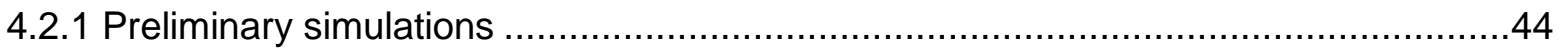

4.2.2 Study \#1: Effect of WWR on PCM performance ……..............................................

4.2.3 Study \#2: Effect of orientation on PCM performance ...............................................59

4.2.4 Study \#3: HVAC set point temperatures and PCM activation ....................................63

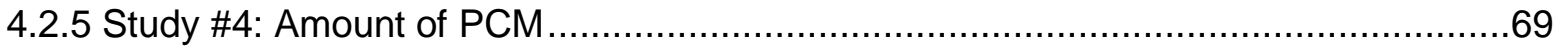




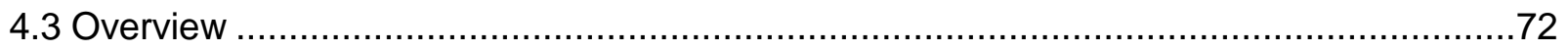

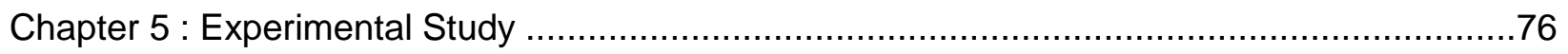

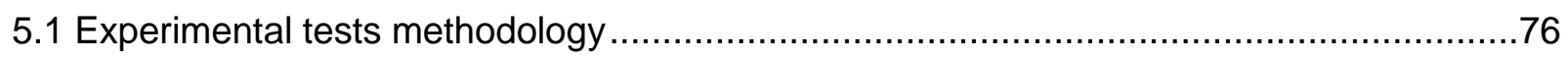

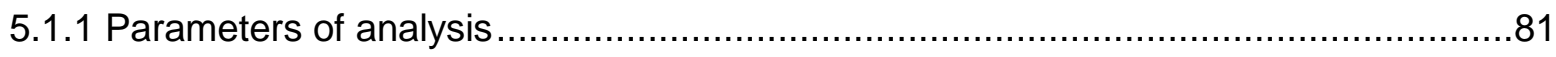

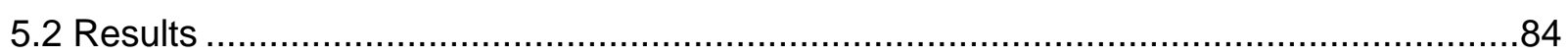

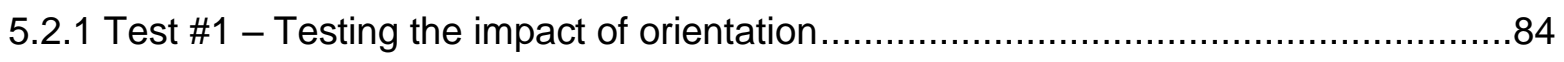

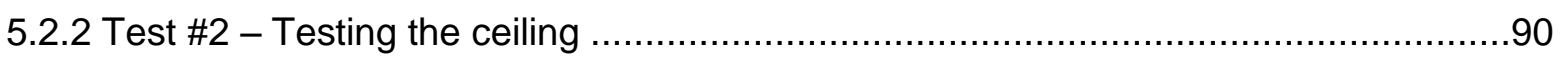

5.2.3 Test \#3 - Testing one wall and one ceiling ........................................................

5.2.4 Test \#4 - Testing the impact of shading and Natural ventilation ...............................96

5.2.5 Test \#5 - Testing individual PCM products ...................................................101

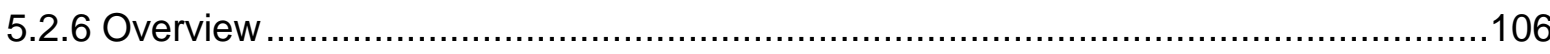

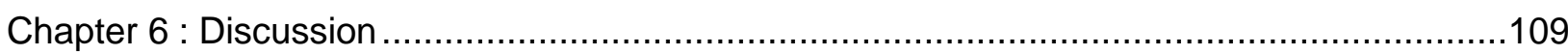

6.1 Correlation of simulation studies and experimental tests ........................................109

6.1.1. Effect of boundary conditions and solar gain on PCM effectiveness .....................110

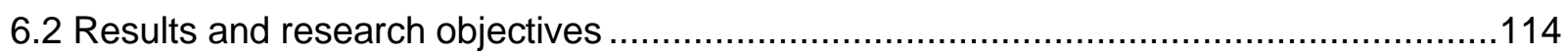

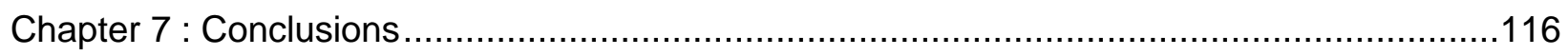

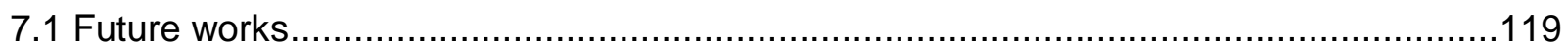

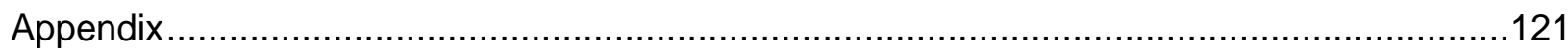

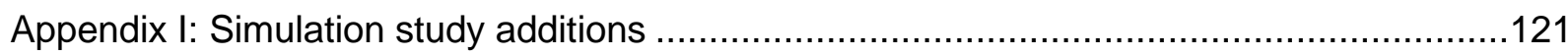

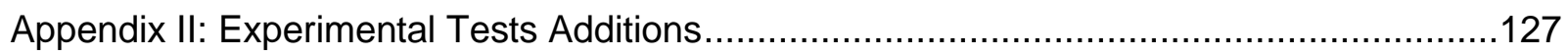

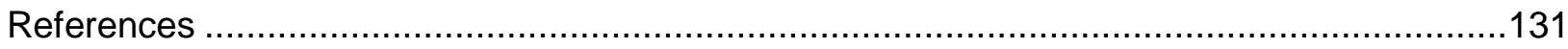




\section{List of tables}

Table 1.1. Annual Energy consumption in high-rise apartments .......................................... 3

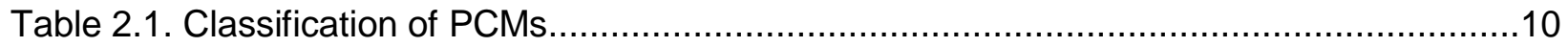

Table 3.1. Numerical studies on PCM applications in buildings .........................................22

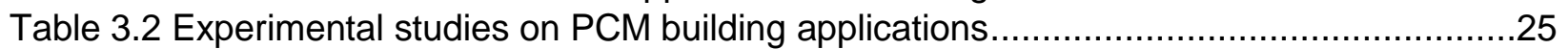

Table 3.3. List of commercial PCM products in the market.................................................30

Table 4.1. Physical properties of the enclosure in the base case model.................................37

Table 4.2. PCM amount integrated into the interior surfaces ...................................................39

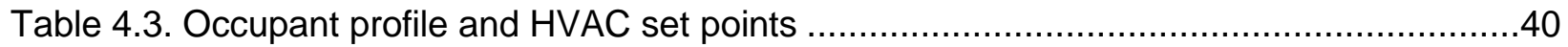

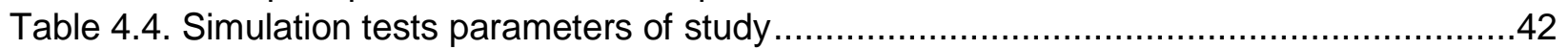

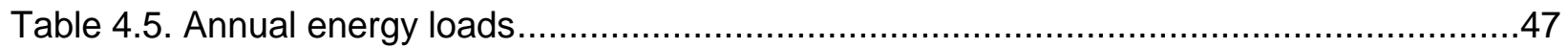

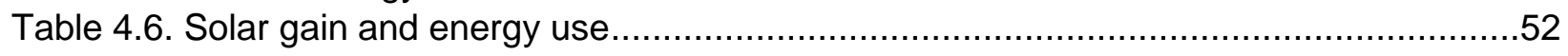

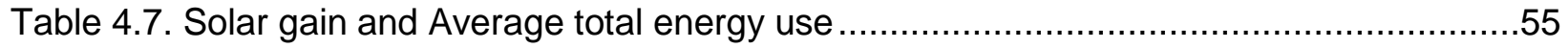

Table 4.8. Change in monthly energy consumption in the PCM integrated unit .......................60

Table 4.9. Alternative heating and cooling set points .......................................................64

Table 4.10. Peak temperature variations by changing set point options- Toronto Units..............65

Table 4.11. Peak temperature variations by changing set point options- Vancouver Units ........67

Table 4.12. PCM amount option in the PCM integrated units ..................................................

Table 5.1. Properties of materials used in the test cell enclosure ...........................................79

Table 5.2. Weight of PCM panles on each surface in the composite PCM cell ........................79

Table 5.3. Climate data for Hamilton, 20-year average values (Government of Canada, 2016) 79

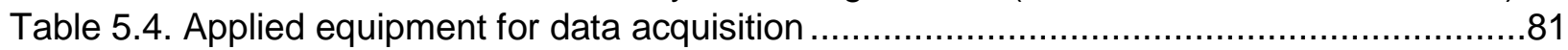

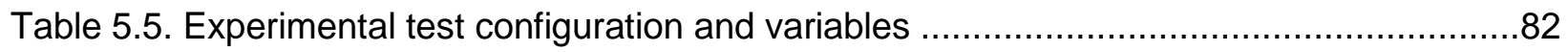

Table 5.6. Impact of the PCM system on different walls of the composite PCM test cell ...........90

Table 5.7. Average outdoor and indoor air temperatures and the impact of composite PCM...108

Table 6.1. Different factors of simulation and experimental study ........................................109 


\section{List of figures}

Figure 1.1. Distribution of residential energy use by end-use, (NRCan, 2016) ....................... 1

Figure 2.1. Sensible and latent energy process diagram (Bruno et al., 2015) ........................ 8

Figure 2.2. Containment method of PCMs and integration in building materials .....................12

Figure 2.3. Measurement of PCM thermal properties (Bruno et al., 2015; Shukla et al., 2012)..14

Figure 2.4. Parameters of interest for designing a PCM system .......................................19

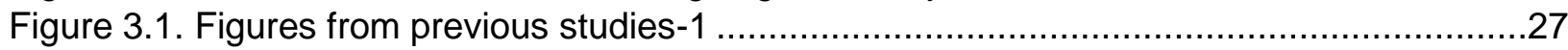

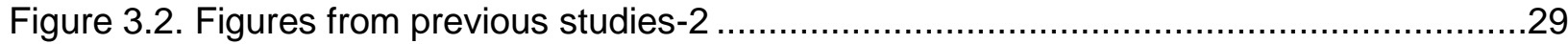

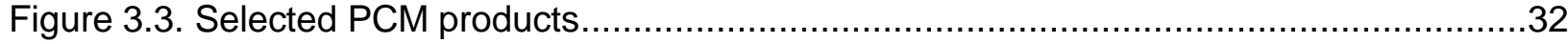

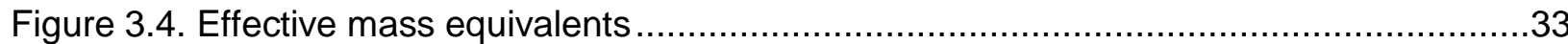

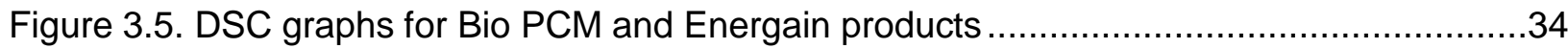

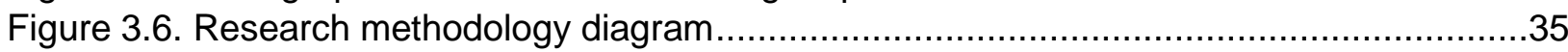

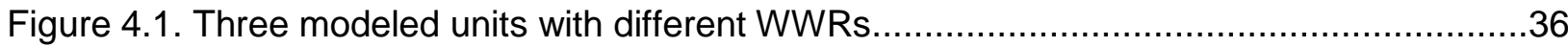

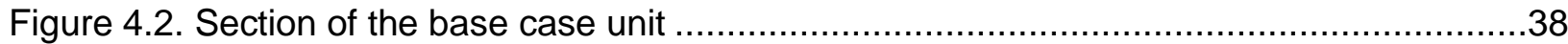

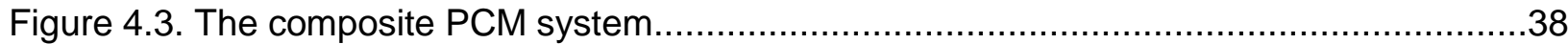

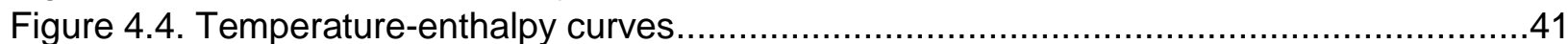

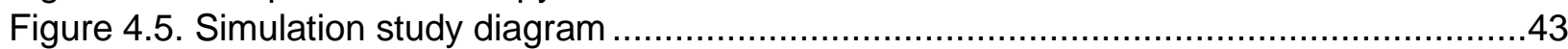

Figure 4.6. Correlation of cooling energy use and air temperature swing changes- Toronto .....44

Figure 4.7. Correlation of cooling energy use and air temperature swing changes- Vancouver.45

Figure 4.8. Cooling Energy use intensity in summer ......................................................

Figure 4.9. Final composite PCM configuration ............................................................ 46

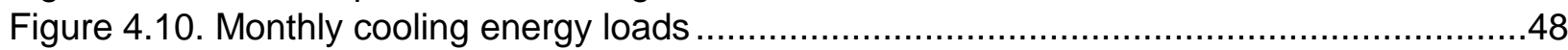

Figure 4.11. Variation in monthly thermal discomfort hours ............................................49

Figure 4.12. Monthly energy and peak load savings in the PCM integrated unit .....................50

Figure 4.13. Rate of change in daily operative temperature swings in the PCM integrated unit.51

Figure 4.14. Energy use and peak shifting in three day periods- Toronto Units .......................53

Figure 4.15. Correlation of average monthly peak load saving and solar gain- Toronto............54

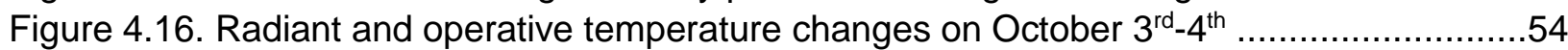

Figure 4.17. Energy use and peak shifting in three day periods- Vancouver Units ....................56

Figure 4.18. Wall surface temperatures and operative temperatures in Toronto.......................57

Figure 4.19. Wall surface temperatures and operative temperatures (Top) in Vancouver ........58

Figure 4.20. Solar gain and rate of cooling energy saving in PCM integrated unit- Toronto.......61

Figure 4.21. Frequency of activation of PCM integrated ceiling and wall ..............................62

Figure 4.22. Monthly energy use in Toronto Units (Variable set point temperatures) ...............64

Figure 4.23. Monthly energy use in Vancouver (Variable set point temperatures) ...................66

Figure 4.24. Frequency of activation based with variable set point ....................................69

Figure 4.25. Correlation of PCM amount and percentage of annual EUI saving ......................71

Figure 5.1 - Plan and Front elevation of a constructed test cell ...........................................76

Figure 5.2- Aluminum structural frame of the test cells .................................................77

Figure 5.3. 1) Test cells facing south - 2) Test cells facing east .......................................77

Figure 5.4. Enclosure composition in reference test cell.................................................. 78

Figure 5.5. 1) Composite PCM cell - 2) Reference cell.......................................................80

Figure 5.6- Connection of two test cells with PVC conduits ............................................ 80

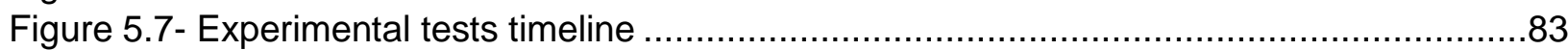

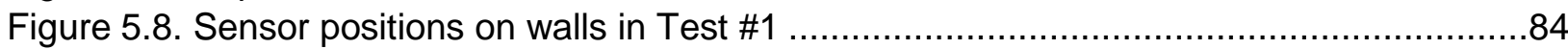

Figure 5.9. Correlation of orientation and peak indoor room temperatures ............................85 
Figure 5.10- Hourly indoor room temperatures from July $3^{\text {rd }}-5^{\text {th }}$

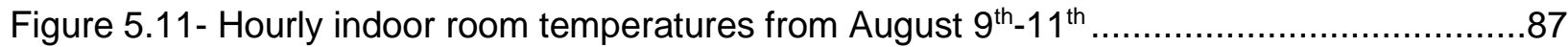

Figure 5.12- Hourly Surface temperatures for the side wall - East Orientation........................88

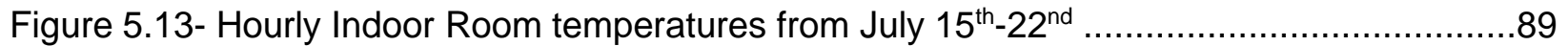

Figure 5.14- Sensor positioning on the ceilings in test \#2..............................................91

Figure 5.15- Rate of heat transfer change between composite PCM and reference surfaces....92

Figure 5.16- Layer temperatures in composite PCM wall and ceiling on August $9^{\text {th }}$ and $22^{\text {nd }} \ldots . .92$

Figure 5.17- Sensor positioning on one wall and ceiling in test \#3 .......................................93

Figure 5.18- Frequency of activation for composite PCM ceiling and side wall in test \#3 .........95

Figure 5.19- Hourly Indoor Room temperature and Side wall surface temperature variations ...96

Figure 5.20- Hourly Indoor Room Temperature and Ceiling surface temperature variations......96

Figure 5.21- Correlation of indoor temperature changes with and without shading ..................97

Figure 5.22- Hourly indoor room temperature variations from October $8^{\text {th }}-10^{\text {th }}-$ Test $\# 4 \ldots \ldots \ldots . .98$

Figure 5.23- Hourly surface temperature and heat flow in the cells from October $8^{\text {th }}-10^{\text {th }} \ldots \ldots \ldots . .99$

Figure 5.24. Individual PCM placements in one side wall in test \#5..................................101

Figure 5.25- Hourly Indoor temperature changes from September $1^{\text {st }}-3^{\text {rd }} \ldots \ldots \ldots \ldots \ldots \ldots \ldots \ldots \ldots . . . \ldots 102$

Figure 5.26- Surface temperature and heat flow variations in the side wall ...........................103

Figure 5.27- Correlation of average indoor air and surface temperatures in each test cell ......104

Figure 5.28- Inner wall layer temperature and heat flow in the Energain cell -August $27^{\text {th }} \ldots \ldots . .105$

Figure 5.29- Inner wall layer temperature and heat flow in the Bio PCM cell -August $27^{\text {th }} \ldots \ldots . .105$

Figure 6.1. Testing solar gain and boundary conditions ................................................110

Figure 6.2. Indoor air, surface and outdoor temperature variations in experimental test cells.. 111

Figure 6.3. Indoor air, surface and outdoor temperature variations in the simulation model ....112 


$\begin{array}{ll}\text { List of abbreviations } \\ \text { CDD } & \text { Cooling degree days } \\ \text { ConFD } & \text { Conduction Finite Difference } \\ \text { DHFMA } & \text { Dynamic heat flow meter apparatus } \\ \text { DSC } & \text { Differential scanning calorimetry } \\ \text { ERM } & \text { Energy retrofit measure } \\ \text { EUI } & \text { Energy use intensity } \\ \text { GHG } & \text { Green house gas } \\ \text { HDD } & \text { Heating degree days } \\ \text { HVAC } & \text { Heating, ventilation and air conditioning } \\ \text { MURB } & \text { Multi unit residential building } \\ \text { PCM } & \text { Phase change material } \\ \text { TES } & \text { Thermal energy storage } \\ \text { WWR } & \text { Window to wall ratio }\end{array}$

\section{Nomenclature}

$\mathrm{C}_{\mathrm{p}} \quad$ Specific heat capacity (KJ/Kg.K)

h Enthalpy $(\mathrm{KJ} / \mathrm{Kg})$

$\mathrm{L}_{\mathrm{f}} \quad$ Latent heat of fusion $(\mathrm{KJ} / \mathrm{Kg})$

$\lambda \quad$ Thermal conductivity (W/m.K)

$\rho \quad$ Density $\left(\mathrm{Kg} / \mathrm{m}^{3}\right)$

RSI Thermal resistance $\left(\mathrm{m}^{2} . \mathrm{K} / \mathrm{W}\right)$

$\mathrm{T}_{\mathrm{mp}} \quad$ Temperature of melting point $\left({ }^{\circ} \mathrm{C}\right)$

Top $\quad$ Operative temperature $\left({ }^{\circ} \mathrm{C}\right)$

$\mathrm{T}_{\mathrm{A}} \quad$ Indoor air temperature $\left({ }^{\circ} \mathrm{C}\right)$

$\mathrm{T}_{\mathrm{R}} \quad$ Radiant temperature $\left({ }^{\circ} \mathrm{C}\right)$

$\Delta \mathrm{E}_{\text {Saving }} \quad$ Rate of heating/cooling energy change (\%)

$\Delta \mathrm{E}_{\text {Peak }} \quad$ Rate of peak load change (\%) 


\section{Chapter 1 : Introduction}

One of the greatest challenges facing the world today is global climate change as a result of the incessant rise in green house gas (GHG) emissions. Changing climatic patterns not only affect the environment, but also complicate human health, social and economical activities. Moreover, considering energy which plays an important role in our lives, implications of climate change on energy supply and demands are critical. The current trends of energy consumption that predominantly relies on non-renewable fossil fuels have raised concerns on high levels of GHG emissions.

The built environment is accountable for nearly $40 \%$ of total GHG emissions. Residential buildings hold the highest share in energy use, particularly space heating claims the highest rate of energy demand. The future prediction for building energy use points to $179 \%$ rise in space heating and cooling demands by 2050 in residential buildings (Berardi, 2017). In Canada, the residential sector accounts for $17 \%$ of total energy consumption, ranking third among industry and transportation sectors (NRCan, 2016). Figure 1.1 shows the breakdown of energy use in residential buildings in Canada.

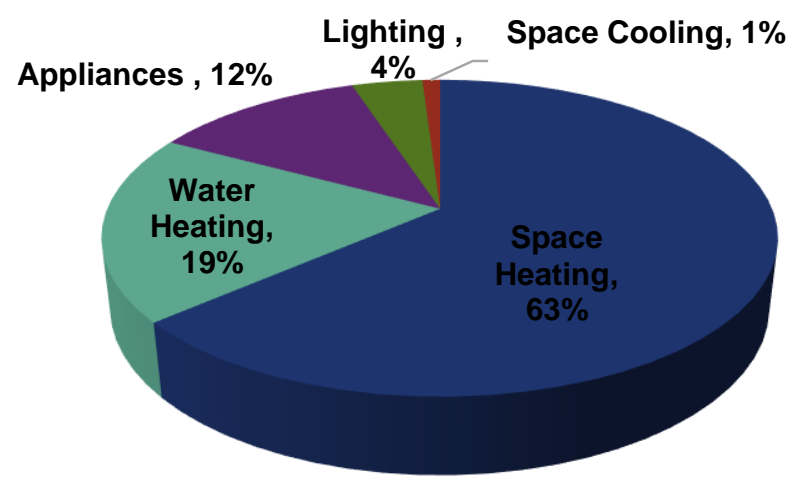

Figure 1.1. Distribution of residential energy use by end-use, (NRCan, 2016)

Fast growing population, social changes and new lifestyles entail population shift and increased urbanization. As a result of concentration in cities, pressure on resources and energy consumption also increases. As stated by Liddle and Lung (2010), a positive relationship exists between urbanization and carbon emissions, in fact, it is noted that half of world's population in cities consume $2 / 3$ of the entire energy resources. While this matter is more pronounced in developing countries, in developed nations such as Canada the link between residential energy use and urbanization is still an important issue.

One of the main factors involved with transitioning population to cities is the surge in the number of dwellings which ultimately require more energy. However, as the number of dwellings increases the number of people per households is often decreased. For instance, in Canada from 1990 to $2013,40 \%$ increase in the number of households was observed, resulting in $6.3 \%$ increase in residential energy consumption, meanwhile, average number of people per household fell by 14\% (NRCan, 2016). 
Considering the pattern of urbanization and housing typology, more and more people live in multi-unit residential buildings in large cities of Canada. Concentration of residents in dense high-rise apartments with smaller footprint is expected to lower energy consumption. However, as surveys and statistics show, while the number of occupants per household has declined, residential floor area has increased indicating more energy per surface area (NRCan, 2016). In addition, the changing weather and rising temperatures in Canadian cities have entailed a declining trend of residential heating demands. Conversely, cooling demands are rapidly increasing specifically as people choose to live in air conditioned buildings.

In order to conform to current social and environmental changes while minimizing the carbon footprint of the built environment, fundamental changes are required to initiate a sustainable development in buildings. Enhancing the efficiency of buildings and switching to renewable energy generation are key factors on this path. Current building codes and regulations consider the need for high-performance construction and mandate specific initiatives for design of healthy, efficient and environmentally friendly designs. However, majority of buildings in Canada were built decades ago pointing to an established existing building stock. The choice is to either replace the entire building stock with new efficient constructions or improve the performance of existing buildings. As stated by Touchie et al. (2014a), the rate of replacing the existing stock in Canada is $1-2 \%$ annually, thus energy retrofit is an essential response to mitigate the environmental impacts of existing buildings.

Energy retrofit of existing buildings is a significant opportunity to reduce energy consumption and carbon footprint as well as enhancing living conditions for occupants by creating better thermal comfort and indoor environment. Moreover, achieving energy efficiency leads to more resiliency and less exposure to fluctuating energy prices which could minimize the operational costs of existing buildings and energy poverty issues (Di Turi and Stefanizzi, 2015). Therefore, addressing the energy and comfort problems using retrofit measures could be more responsive in lowering the footprint of buildings while improving the quality of life for occupants.

The focus of this study is on high-rise residential buildings in two major Canadian cities of Toronto and Vancouver which are the main hubs of multi-unit residential housing stocks in Canada. High-rise apartments represent $10 \%$ of total dwellings in Canada, $50 \%$ of total dwellings in Toronto and 34\% in Vancouver (NRCan, 2016; RDH, 2012; Touchie et al., 2014a). These buildings are responsible for nearly $40 \%$ of total GHG emissions in Toronto and Vancouver (Touchie et al. 2014a). Pertaining to the vast numbers of these buildings and their fast-growing market it is essential to apply energy efficiency measures in this typology. Adapting existing high-rise apartments to contemporary standards provides a vast research area to find appropriate means to enhance the energy efficiency of the housing stock.

\subsection{Background: High-rise residential buildings}

Evolution of multi-unit apartment buildings in Canada started after 1960's as a result of post-war growth and continues to develop today. High-rise residential towers represented an era of change and modernization in large cities. This model of housing was contrasting to the previous urban sprawl with the aim of forming self-sufficient communities in dense clusters (Kesik and Saleff, 2009). Shortage of suitable lands, easy access to amenities and public areas are some factors for which these buildings remain a popular form of housing today (RDH, 2012). 
However, years after their construction, aging high-rise apartments face crucial problems. Lack of maintenance has led to deterioration of building components which cause serious issues such as leaky envelope, moisture problems and water damages to the building fabric and interior surfaces. Moreover, wasteful energy consumption characteristics as a result of poor aging performance is a critical concern in these buildings. The majority of high-rise apartments were constructed in an era of cheap energy prices, thus energy efficient construction was not an important criterion as it is today. All these factors with time degrade the quality of life in high-rise apartments which has caused large rates of complaints and cost issues for building owners (Alsaadani et al., 2016). Decreased indoor air quality and thermal comfort are the two major problems occupants experience in these buildings today $(\mathrm{RDH}, 2012)$.

Several studies have investigated energy consumption characteristics of MURBs in Toronto and Vancouver. Table 1.1 summarizes the results of some studies showing the average energy consumption values in these buildings.

Table 1.1. Annual Energy consumption in high-rise apartments

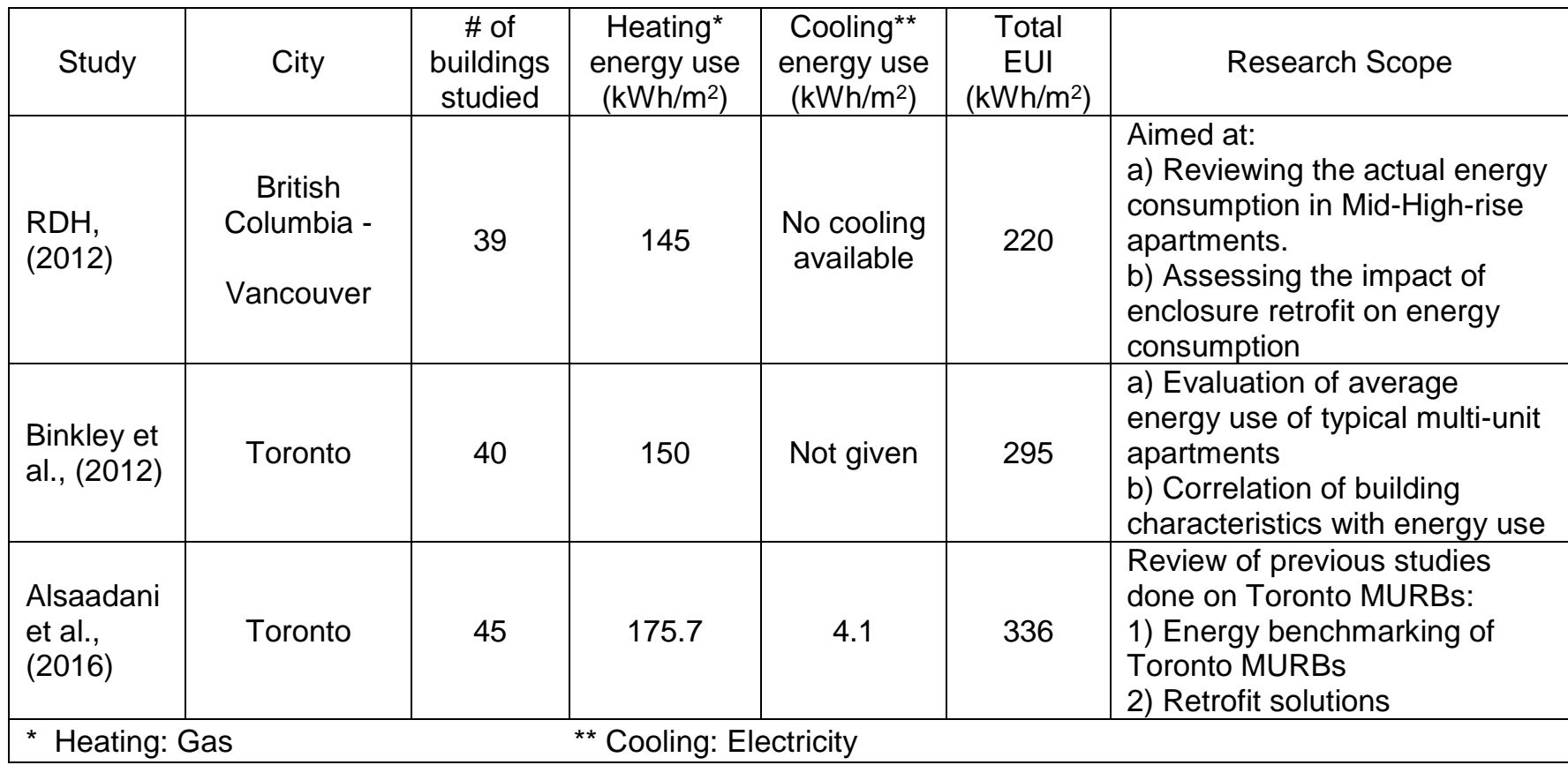

As evident from the energy trends stated in Table 1.1, a high share of energy use in buildings is allocated to space conditioning to provide thermal comfort for occupants. In older buildings, aging infrastructure, lack of proper insulation and poor performing windows result in high discomfort levels in spaces. However, in newer buildings which are constructed mainly with glazed facades, high solar heat gain and heat loss in spaces lead to large temperature fluctuations, demanding higher heating and cooling (Binkley et al., 2012).

According to ASHRAE 55 (2013), thermal comfort is described as a condition of mind that expresses satisfaction with the thermal environment. Thermal comfort depends on multiple parameters that must meet a specific standard to create a comfortable zone. Even though perception of thermal comfort is not the same for everyone, some main indoor problems such as draft, daily temperature swings, and vertical temperature stratification are some of the most common problems that affect occupant comfort levels (Bradshaw, 2006). Temperature 
variations with time create major comfort problems and prompt occupants to adjust their conditioning system more often to provide a satisfying indoor environment. This higher reliance on mechanical systems in addition to higher energy uses and costs implies a lower resiliency in high-rise apartment buildings.

One approach to improve the thermal environment in buildings is thermal energy storage. Traditionally, heavy and high thermal mass structures such as masonry or adobe provided thermal energy storage in buildings which passively regulated indoor conditions year-around without any mechanical systems. Thermal energy storage reduces temperature fluctuations in spaces and could reduce the mismatch between energy supply and demand. (Heier et al., 2015; Soares et al., 2013). Therefore, this study focuses on thermal energy storage as an unconventional retrofit measure to reduce energy consumption for space conditioning.

\subsection{Research Aim}

High energy consumption, GHG emissions and discomfort levels in high-rise apartments in two cities of Toronto and Vancouver have created challenging issues. To address the environmental implications of high-rise apartments while conserving their entirety, energy retrofits are required.

In this research, passive thermal energy storage, as a viable retrofit measure, is considered to address indoor environment and energy consumption in high-rise apartments. The incorporation of latent thermal energy storage using Phase Change Materials (PCMs) in indoor unit spaces is proposed. PCMs store heat by undergoing a state change. Passive storage systems can be a beneficial addition to high-rise apartments considering large temperature fluctuations caused by poor insulation levels in old apartments and high glazing ratios in newer apartments.

The aim of this thesis is to evaluate the effectiveness of integrating PCM applications in apartment units in regulating indoor temperatures and reducing energy consumption.

\section{The central focus of this study is to find:}

* The relation between solar heat gain in apartment units and the effectiveness of PCMs' thermal energy storage;

* The connection between indoor air temperatures with the melting temperature of PCMs by monitoring their performance and impact on energy use and indoor temperatures

The following objectives are addressed in this study:

- Identifying appropriate PCM products considering climate, application, and melting temperature range;

- Quantifying the detailed performance of the selected PCM application;

- Determining the energy saving and thermal comfort implications of PCMs in Canadian buildings

The main scope of this research is to investigate the impact of climate, indoor boundary conditions and solar gains on PCM performance. Furthermore, the results of this thesis will provide a retrofit model using PCMs that can be adopted in future research. 


\subsection{Thesis outline}

Chapter two explores the literature starting with studies that outline influential parameters affecting energy and thermal comfort in high-rise apartments in Toronto and Vancouver. The following sections of chapter two are dedicated to thermal energy storage applications in buildings, their benefits, and drawbacks. Furthermore, a review of previous research on PCM integration in buildings is provided with an analysis of research variables and findings to investigate the gap in research.

Chapter three summarizes the overarching methodology in the research with a review of research methodologies and approaches in the literature for quantifying the performance of PCMs integrated into buildings.

Chapter four discusses the simulation analysis performed on typical apartment units in Toronto and Vancouver. A preliminary analysis is performed to determine the suitable PCM products for the context of this research. Subsequently, the impact of selected PCM system on indoor temperatures and energy use is investigated.

Chapter five outlines experimental tests carried out using outdoor small scale test cells. The complete process of experimental tests, as well as the construction of test cells, are detailed. Results of different tests performed to analyze the exact performance of the proposed PCM system in different testing periods is outlined.

Chapter six combines the results of both simulation and experimental tests with correlations between these results.

Chapter seven presents the final outcomes and conclusion of the study linking the results with original research focus and objectives. Suggestions for future work are also finally presented. 


\section{Chapter 2 : Literature Review}

The following literature review covers previous research on the application of PCM products in buildings. First, an insight into thermal energy storage systems in buildings is provided followed by an introductory overview of phase change materials, their important parameters and their integration in building applications. Different applications of PCMs in buildings and their impact on energy use and indoor temperatures in multiple studies with varied contexts are investigated. Furthermore, factors affecting PCM performance are also reviewed to assist in designing an appropriate PCM system. This background study is necessary to understand the gap in the research. Moreover, by reviewing previous approaches, a new direction for the analysis of PCMs in this stud would shape.

\subsection{Retrofit of High-rise apartments}

Multiple studies have investigated retrofit potentials and opportunities in high-rise multi-unit apartments in Toronto and Vancouver. The main approach in existing studies is first to review the current performance characteristics of these buildings, and then to propose numerous retrofit interventions relevant to each case.

Kesik and Saleff (2009) have outlined a comprehensive guideline for tower renewal projects in Toronto. An initial background on construction principles of tower buildings was introduced in addition to condition assessment of multiple case studies. Alsaadani et al. (2016) provided a review of studies performed on high-rise apartments in the city of Toronto. Two reports on energy trends of mid-high rise MURBs in Toronto (Binkley et al., 2014) and Vancouver (RDH, 2012) have studied the baseline energy consumption of several case studies to show how these buildings perform and to analyze their energy use and GHG emissions on a large scale.

An important part of previous studies is the analysis of factors that affect energy demand in high-rise apartments. The most influential factors are: age and size of buildings, air tightness, efficiency of HVAC systems, thermal resistance of the enclosure, glazing properties, and occupant behavior.

The energy use trends of high-rise apartments studied by RDH (2012) and Binkley et al. (2012), showed a pattern of increased energy use in newer high-rise apartments. It is argued that in older buildings the higher EUI is largely due to inefficient mechanical systems while in newer buildings the positive impact of better performing enclosure and mechanical systems are offset by high glazing ratios. With new architectural designs shifting towards complete transparent facades, punched in windows are being replaced by floor to ceiling window-wall systems covering $80 \%$ or more of the total facade area.

Binkley et al. (2012) suggested that fenestration ratio has the highest impact on energy use in high-rise apartments. The negative impacts of high glazing ratios degrade the effect of improved thermal resistance of opaque surfaces in newer buildings (Kesik and Saleff, 2009; McKeen and Fung, 2014; Touchie et al. 2014b). Adverse implications of large fenestration ratio on cooling loads in high-rise apartments are due to large solar gains and conductive heat gain. Windowwall systems have large air leakages in the framing areas which leads to high heating demand. Higher heat gain and heat loss attributed to large WWRs is indicated as a principal cause of discomfort stated in various studies (Rodriguez-Ubinas et al., 2013; McKeen and Fung, 2014). 
Ozkan et al. (2016) have investigated the influence of passive retrofit measures in high-rise apartments of Toronto to address energy use, thermal comfort and resiliency. Similarly, in this study window to wall ratio was considered as a critical factor affecting energy consumption. Ozkan et al. (2016) suggested several promising passive strategies for better energy efficiency, indicating envelope thermal performance as the key parameter.

$\mathrm{RDH}$ (2012) conducted a complete envelope retrofit in 39 sample buildings in Vancouver and the results demonstrated $8 \%$ reduction in total energy use with total heating energy saving of $14 \%$, which was achieved by increasing the thermal resistance of the enclosure by $30 \%$. In a subsequent study performed by Touchie et al. (2014a), four of the case study buildings that were previously reviewed were considered for energy retrofit using three different interventions; HVAC upgrade, enclosure improvement and reduction of electrical loads. The findings indicated notable benefits of energy retrofit with an estimated overall $16 \%$ reduction in GHG emissions.

Concerning the results of previous studies on energy retrofits, significant improvements can occur in energy performance in high-rise apartments which present large opportunities to reach energy efficiency. However, by investigating the literature on energy retrofits, it is inferred that the industry has focused more on R-values as the initial determinant for energy efficiency in retrofit projects. However, thermal mass is another potential strategy that could positively impact energy consumption by regulating indoor temperature distributions. Lack of research on thermal mass as a retrofit intervention in the Canadian context has prompted this study to evaluate its effectiveness and potential.

\subsection{Thermal energy storage}

Thermal energy storage (TES) is the ability of materials to absorb and store energy to be released at a later time (Hoes and Hensen, 2015). Thermal storage could be short term (daily, hourly) or long term (seasonally, yearly) depending on the specific function required and systems involved. The impact of thermal mass on indoor comfort is mainly due to increased temperature stabilization which is a result of decreased indoor temperature swings and reduced temperature extremes. TES targets energy use reduction by limiting demands and transfer of loads in time referred to as "peak shifting" (Taylor and Miner, 2014). Time shifting with appropriate thermal mass methods can move the demand for cooling or heating away from peak hours which have the highest stress and pressure on the grid. Thermal lag resulted from thermal mass increases the resiliency of buildings in unprecedented events such as power outages. Indoor temperatures can be constant for several hours or even days to maintain a livable environment for the occupants as a result of thermal lag.

TES systems are divided into passive or active systems. Passive thermal storage does not involve mechanical or active mechanisms, thus the process is completely driven by temperature difference between the storing medium and the surroundings. Conversely, active thermal storage involves mechanical systems such as pumps or fans to charge and discharge the storage medium such as storage in HVAC systems or in thermally activated building systems. Heier et al. (2015) have performed an extensive overview of TES systems in buildings. The focus of this thesis is on passive thermal storage which could potentially reduce dependency on fossil fuels by regulating indoor temperatures without extra mechanical systems. 
Two main types of thermal storage are sensible heat and latent heat storage. In sensible storage, thermal energy is stored in materials as a result of large temperature differences across the thickness of the material (Sharma et al. 2009). The amount of heat stored in sensible storage depends on the specific heat, temperature difference, and mass of the material ( $E Q$ 2.1.a). Sensible storage traditionally used in buildings is storage in high mass materials such as masonry or concrete.

Latent energy storage is when materials store heat by undergoing a phase change at specific temperature points, such as changing from solid to liquid states. Phase change materials are a latent heat storage system and they store both sensible and latent heat as shown in Figure 2.1 and EQ. 2.1b. As the figure shows, latent heat storage process occurs at a specific melting point at a constant temperature while the enthalpy or heat content of the materials changes.

$\mathrm{Q}=\int_{T 1}^{T 2} m C p d T$

$\mathrm{Q}=\int_{T 1}^{T 2} m C p d T+\mathrm{m} \Delta \mathrm{h}+\int_{T 2}^{T 3} m C p d T$

Equation 2.1. a) sensible heat storage b) latent heat storage (Sharma et al., 2009)

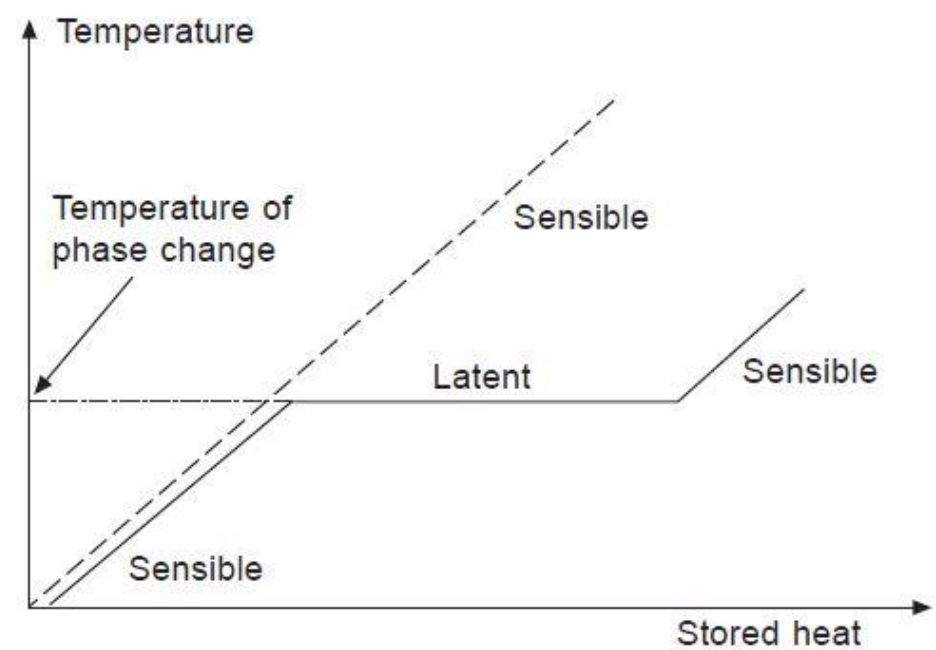

Figure 2.1. Sensible and latent energy process diagram (Bruno et al., 2015)

High thermal mass materials such as masonry, brick, and concrete are good providers of sensible storage and were predominantly used in older buildings with heavy structure. The current method of construction is building with light frame structures which has several advantages such as better use of space, quick construction, economic, and environmental benefits. However, the effective thermal energy storage capacity of light weight steel and wood frame structures are much lower compared to heavy structures. As stated by Fiorito (2014), Fraser (2009), and Hoes and Hensen (2015), lower levels of thermal mass in light frame buildings leads to high levels of discomfort in light weight structures.

Maintaining an acceptable level of thermal comfort depends on several environmental and design considerations. According to Straube and Burnett (2005), air temperature is not an 
accurate measure for thermal comfort, while operative temperature which in simple terms is a mean average of air and radiant temperatures, is a better representative of thermal comfort. In the review provided by Bradshaw (2006), the impact of radiant heat on thermal comfort is considered very critical, specifically, the relation of radiant and air temperature in buildings.

Radiant temperature can be stabilized by applying thermal mass in buildings. Reducing energy consumption while regulating temperatures with sensible heat storage in buildings could be contradictory since materials with sensible storage require large temperature differences for heat storage. Latent heat storage systems are proposed for this study as an appropriate choice as they operate in narrow temperature ranges. Furthermore, compared to sensible storage, latent heat storage systems have 5 to 14 times more heat storage capacity per unit volume (Soares et al., 2013).

Multiple studies have investigated the impact of thermal mass by comparing different building structures and the results indicated better energy performance and higher comfort levels in buildings with larger thermal storage capacity (Fraser, 2009; Noren et al., 1999). As previously stated, large glazing ratios in high-rise apartments entail high discomfort levels, which could be addressed by TES integration. In a study conducted by Van Straaten et al. (2016) on residential high-rise apartments of Toronto, window-wall systems were replaced with precast concrete walls. The aim was to incorporate thermal mass for increased resiliency in times of power outage and reduce the impact of heat loss and heat gain by minimizing the window areas. The results indicated that adding precast concrete walls combined with reduction of WWR reduces the heat loss by $43 \%$.

Even though the results of existing studies show an improvement with incorporation of sensible storage, it is not quite feasible to incorporate high thermal mass materials in retrofit applications (Ascione et al., 2014; Sharma et al., 2009). Further comparison of sensible and latent storage shows multiple benefits associated with latent thermal storage using PCMs:

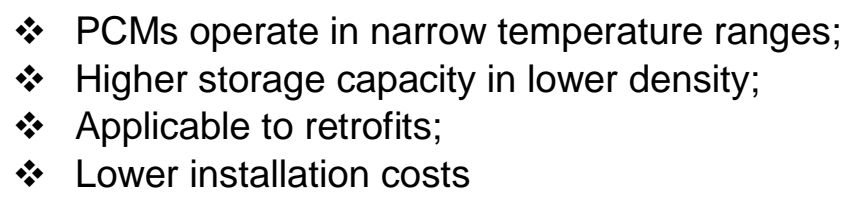

Referring to section 2.1, it was discussed that R-value or increasing thermal resistance of the enclosure is the prominent retrofit target considered in refurbishment projects. Therefore, it is necessary to articulate the context of high thermal mass and high thermal resistance in conjunction. The building envelope is the separation of two different environments balancing the internal and external loads to create a comfortable environment. The design of building envelopes is primarily expressed by considering steady-state heat flow. However, indoor and outdoor environmental conditions are constantly changing (Straube and Burnett, 2005).

Insulation reduces the heat flow to and from the building while applying TES allows for absorption and storage of excess solar gain and excess heat coming through the enclosure. While insulation levels, specifically exterior insulation, minimizes heat transfer, thermal storage could address the indoor radiant temperature (Rodrigues et al., 2015). Including thermal mass on the interior side of the buildings could mitigate dynamic changes and fluctuations to provide a comfortable living space. Thermal mass is not an alternative to insulation rather it complements the thermal resistance of the walls specifically in the summer period. 
The majority of residential high-rises in Toronto and Vancouver are constructed with concrete structure, thus they already contain a certain level of thermal mass. However, integrating PCMs in older buildings with low WWR and newer buildings with fully glazed facades, as an addition to the existing thermal capacity of the concrete, can improve indoor temperature distribution, Despite the wide range of PCM applications in light-weight frame buildings, several studies such as Evola et al. (2013), Fraser (2009), and Rodriguez- Ubinas et al. (2013), have investigated the addition of PCMs to masonry or high mass buildings. All three studies emphasized the positive supplement of PCMs to the performance of the existing thermal mass. Baetens et al. (2012) have indicated that addition of PCMs to concrete or addition of PCMs to concrete structures shows significant increase in heat capacity.

\subsection{Phase change materials}

Phase change materials provide latent heat storage systems and are used in multiple applications ranging from microelectronics, food packaging and sports clothing to large scale applications such as storing energy in large solar plants and spacecraft research projects of NASA (Fleischer, 2015). PCMs have been used as a thermal storage medium since the 1800s and their first utilization in buildings was in 1940s. The growing research on PCM integration in buildings has resulted in numerous advances associated with PCM's technical and physical properties. Such advances have allowed for mass utilization of PCMs as a promising innovative TES system to reduce energy consumption in the built environment.

The phase transition capability of PCMs allows for energy storage and thermal management by temperature stabilization. Phase change can be from solid to solid, solid to liquid, solid to gas and liquid to gas. However, the most attractive and practical form of phase change is the solidliquid state change as the volume change of PCMs is lowest (Pasupathy, et al., 2008a; Sharma et al., 2009; Soares, et al., 2013). PCMs are categorized into organic, inorganic and eutectic types which are a mixture of two previous types. Table 2.1 shows a comparison of different PCM types based on findings from the literature.

Table 2.1. Classification of PCMs

\begin{tabular}{|c|c|c|c|}
\hline Classification & Types & Advantages & Disadvantages \\
\hline Organic PCMs & $\begin{array}{l}\text { - Paraffins (petroleum } \\
\text { or non-petroleum } \\
\text { based) } \\
\text { - Non-paraffins (bio- } \\
\text { based) } \\
\text { - Fatty acids } \\
\text { - Alcohols } \\
\text { - Glycols }\end{array}$ & $\begin{array}{l}\text { - Readily available in the market } \\
\text { - High latent heat of fusion } \\
\text { - Physically and chemically stable } \\
\text { - Increased lifespan (number of phase } \\
\text { change cycles) } \\
\text { - Recyclable } \\
\text { - Available for large temperature ranges }\end{array}$ & $\begin{array}{l}\text { - Melting over a temperature } \\
\text { range, not one point } \\
\text { - Low conductivity } \\
\text { - Moderately flammable } \\
\text { - Instability to high } \\
\text { temperatures }\end{array}$ \\
\hline $\begin{array}{l}\text { Inorganic } \\
\text { PCMs }\end{array}$ & $\begin{array}{l}\text { Salt Hydrates } \\
\text { (Salt+water) } \\
\text { Metals } \\
\text { Alloys } \\
\text { Salts }\end{array}$ & $\begin{array}{l}\text { - Higher conductivity } \\
\text { - Higher latent heat of fusion per unit volume } \\
\text { - Not flammable } \\
\text { - Lower cost } \\
\text { - More than double volumetric heat capacity } \\
\text { compared to organic PCMs }\end{array}$ & $\begin{array}{l}\text { - Incongruent melting } \\
\text { - Phase segregation } \\
\text { - High supercooling } \\
\text { - Corrosive to building } \\
\text { materials } \\
\text { - High volume changes }\end{array}$ \\
\hline
\end{tabular}


Organic PCMs particularly paraffin based PCMs are the most used products in the market and in previous studies as they are chemically stable, non-corrosive and recyclable (Bruno et al. 2015). Non-paraffin or bio-based PCMs such as fatty acids, alcohols or glycols are the largest group of PCMs with very different properties. They are often made from agricultural byproduct waste which makes them more environmentally friendly, non-toxic and less susceptible to crude oil price changes in addition to being less flammable.

Salt hydrates are the most widely used inorganic PCM for building applications, which in fact have been in use from the beginning of PCM building incorporation for their higher latent and specific heat properties. Nevertheless, inorganic PCMs are corrosive to most metals and have shorter life spans which make their application difficult.

Considering melting range and latent heat of fusion applicable to building products, paraffin, salt hydrates and fatty acids are the most appropriate options. An extensive list of different available PCM products are categorized in studies done by Kenisarin and Mahkamov, (2005); Kosny (2015c); Pasupathy et al. (2008a); Sharma et al. (2009), and Tyagi and Buddhi (2007).

PCMs can be applied to building materials to act as passive thermal storage mediums or be incorporated into active building systems. Adoption of PCMs in HVAC or other active systems in the buildings allows for improvement of their technical performance. Some of these applications studied in previous research are hot water heat storage tanks and AC systems.

PCMs can be incorporated into porous building materials such as gypsum boards, brick, concrete, insulation, and tiles by various methods. Gypsum boards are the most widely researched product in the literature for their suitability, convenience and their large application in buildings. In fact, most of the studies reviewed in this paper have investigated the performance of PCM wallboards (Ascione et al., 2014; Athienitis et al., 1997; Evola et al., 2013; Shilei et al., 2006). Extensive research has been done on typical construction materials integrated with PCMs, for instance, Pasupathy and Velraj, (2008) and Narain et al. (2016), investigated PCM addition to concrete. Kosny et al. (2012) performed tests on a mixture of fiber insulation and PCMs, Ceron et al. (2011) analyzed the impact of floor tiles embedded with PCMs.

The important factor regarding PCM integration in building materials is first the method of PCM containment in the carrier material, second is the amount of PCM embedded into the carrier. There are several methods of PCM integration into building materials, direct immersion, bulk containers, and encapsulation are the main strategies (Kenisarin and Mahkamov, 2016; Kosny, 2015a). In the direct immersion method, PCMs are directly added to the structure of porous building component by soaking the porous carrier material in melted PCMs. Even though this method is simple and relatively inexpensive, it poses serious issues of material leakage, especially when PCMs are liquid, this influences the structural integrity of the carrier material.

Encapsulation acts as a barrier between PCMs and the carrier material which according to the literature is the most effective method to control and prevent PCMs from leaking (Kuznik et al. 2015; Soares et al. 2013). This method is categorized into micro-encapsulation and macroencapsulation in which the PCMs are surrounded by a different self-supporting material to isolate them from the surrounding. Micro-encapsulation is simply coating the PCMs by a polymeric shell in microscopic sizes [ $\mu \mathrm{m}-\mathrm{mm}]$ that could be applied to most porous materials. Macro-encapsulation uses three-dimensional geometric materials to enclose PCMs such as in spheres or tubes on a larger scale of nearly $1-10 \mathrm{~cm}$ which could present design challenges in building enclosure applications. 

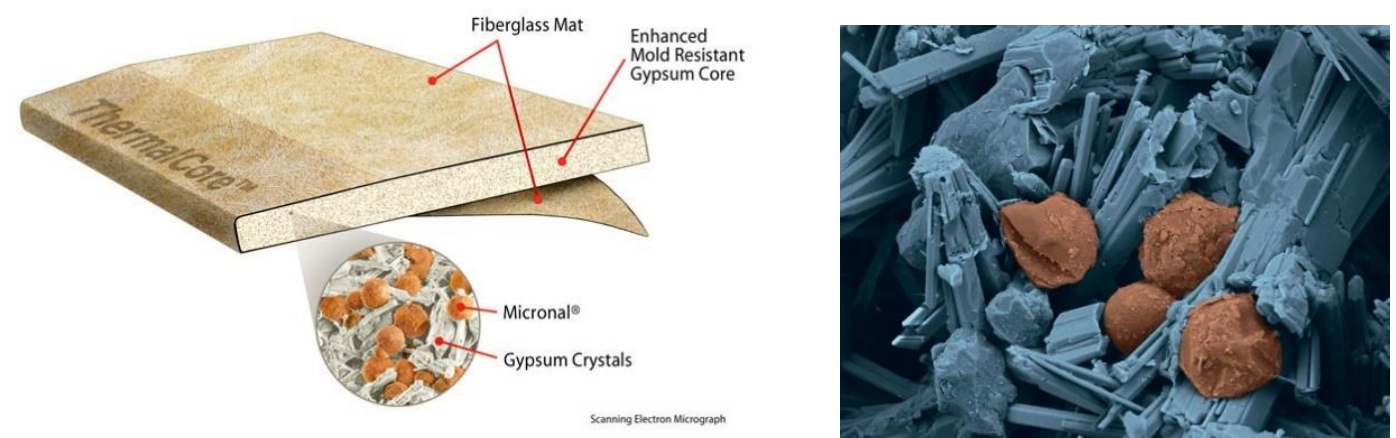

a) Direct immersion in building materials- Gypsum boards (BASF, 2016)

1)

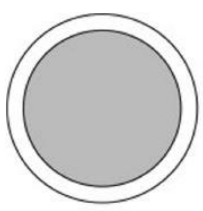

Mononuclear

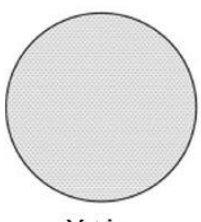

Matrix

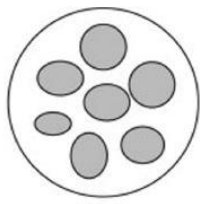

Polynuclear

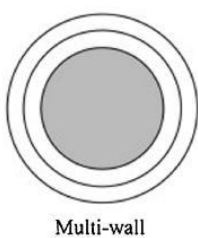

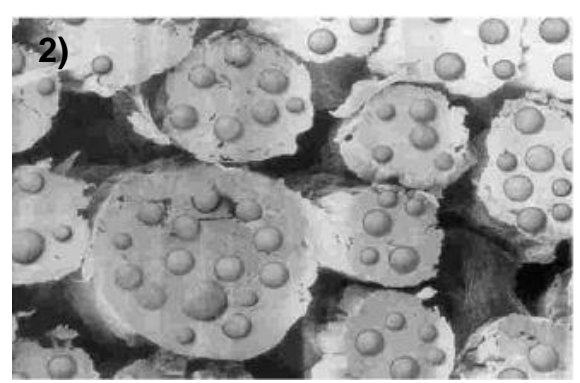

b) 1) Microencapsulation types- 2) Microcapsules in fiber (Guruprasad et al. 2017)
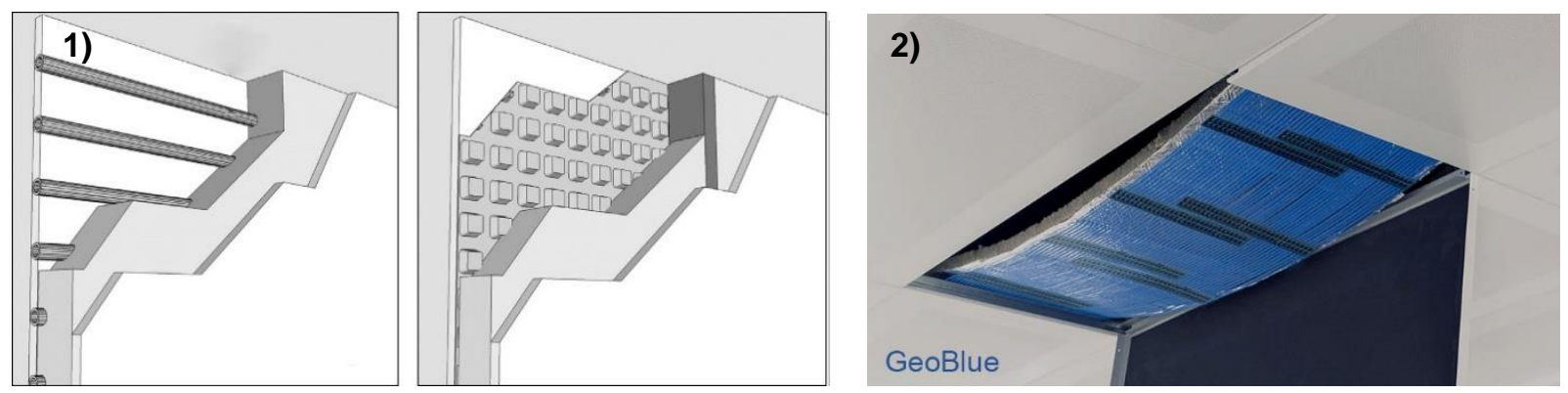

C) 1) Macro-encapsulated PCMs (Rodriguez-Ubinas et al. 2013); 2) (ThermaCool, 2016)

Figure 2.2. Containment method of PCMs and integration in building materials

Different PCM packaging such as plastic pouches, bags of PCMs and aluminum foil packages are some examples of macro-encapsulation or bulk containment widely used for building applications. Macro-encapsulation is a promising strategy since it is considerably cost effective and could become the dominant trend in future of PCMs for building materials (Kosny, 2015a). Micro-encapsulation by far has proven to be the most reliable and preferred method of PCM inclusion in building materials (Kosny, 2015a; Pasupathy et al., 2008a ,Soares et al., 2013). 


\subsubsection{Mechanism}

The dynamic and non-linear phase change in PCMs is basically a change in energy content or enthalpy of materials in a constant temperature. In simple terms as shown in Figure 2.1, when the indoor temperatures rise, PCMs store sensible energy until the melting temperature is reached. In a near constant temperature or temperature range, they start to melt in an endothermic process in which the latent heat of fusion is stored. When the indoor temperatures fall below the melting point, the PCMs are gradually cooled, thus they dissipate the stored heat back to the indoor space as they return to solid phase through an exothermic reaction.

The sensible energy affects molecular vibrations and kinetic energy of molecules which entails temperature changes. Latent heat energy is added to or released to break the molecular bonds without any significant vibration thus temperature remains constant. During the melting and solidification process, a moving boundary or interface is created. This separates the solid and melted portions of the PCMs referred to the mushy zone. Heat transfer in this moving interface needs to be calculated as discussed by Sharma et al. (2009) and Ziskind, (2015) considering different thermophysical properties between the solid and liquid phases.

Constant temperature during the phase change process is a key factor resulting in uniform space temperature as the transition takes place. The excess heat in buildings caused by solar heat gain, internal gains by occupants or appliances is absorbed during the day and is released back to the space at night when temperatures are colder to compensate for heat loss from the space. The important effect of constant temperature during phase transition is the stabilization of temperature swings as the dynamic heat storage eliminates sharp high peak periods. This stabilization is directly linked with the time lag created by the PCM.

\subsubsection{Characteristics of PCMs}

The first step in investigating PCM integration in buildings is dedicated to selecting an appropriate PCM system based on their thermophysical characteristic. Design of a suitable PCM system requires specific physical, chemical and thermal characteristics that must be in correlation with context of the building and the application they are intended to. PCMs are characterized by multiple properties that influence their performance, the most important are:

* Melting temperature: The temperature or temperature range in which the PCM starts to undergo the state change. In order for PCM activation, their melting range must correspond with the environment they are applied to. The melting range of PCMs must fall within the indoor temperature range. If the buildings are conditioned, PCMs' melting temperatures could be matched with the operating set point temperatures of the system and in case of no mechanical conditioning, with average outdoor conditions (Fiorito, 2014; Fleischer, 2015; Shilei et al., 2006). In all studies reviewed, melting temperature of PCMs is regarded as the most important parameter linked to PCM performance.

* Latent heat of fusion (Enthalpy of phase change): Latent heat is a material specific property which shows the amount of heat energy absorbed or released during a state change. A higher latent heat entails a higher heat storage during the phase transition, thus materials with higher heat of fusion are preferable. The total amount of latent heat storage depends on 
the amount of PCMs, therefore carefully examining the amount and density of PCM applications is crucial for total heat storage capacity (Castell and Sole, 2015).

- Specific heat: High specific heat provides an additional sensible heat storage for the PCMs as they are capable of both latent and sensible storage.

* Thermal conductivity: High thermal conductivity of PCMs in both melted and solid states is important to ensure a proper heat transfer for PCM activation. Conductivity in PCMs affects the rate at which the heat storage develops as it can accelerate or delay the process.

* Congruent melting: congruent melting and freezing in each full cycle of PCMs entails a longer stability and increases the lifespan of the products.

Furthermore, some key problems associated with PCMs such as sub-cooling, nucleation or phase segregation and low thermal conductivity for certain PCMs must also be considered. Low thermal conductivity of PCMs is a major limitation of these products and is an important factor specifically for the solidification cycle of PCMs. There are however multiple strategies proposed in studies done by Bruno et al., (2015), Kenisarin and Mahkamov, (2005), and Kosny, (2015a) to enhance thermal conductivity of PCMs.

As evident, thermophysical characteristics of PCMs are critical for the activation of PCMs. Thermal performance analysis of PCMs for measuring dynamic thermal properties of PCMs is performed using different methods such as Differential Thermal analysis (DTA), T-History method, Differential Scanning Calorimetry (DSC) and Dynamic Heat Flow Meter Apparatus (DHFMA). Expanding on these test methods is out of the scope of this research, however, a brief description of the last two tests is presented in Figure 2.3.
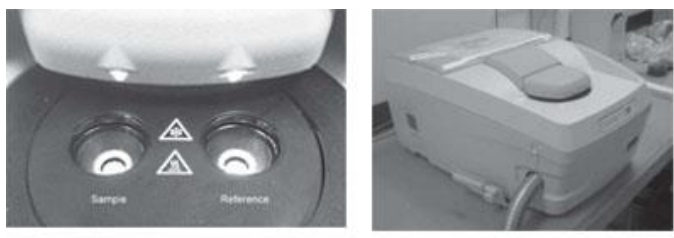

DSC Test

Heat of fusion is calculated by heating or cooling samples isothermally from inital temperature to above the Tmp to record the latent heat.

- Small sample sizes- (milligrams)

- Two samples to be tested simultenously

- Only pure samples

- Not an accurate method for non-homogenous materials

- Measurements depend on heating/cooling rates, samples sizes and weight
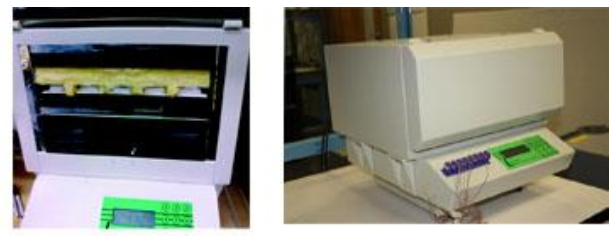

\section{DHFMA Test}

Using temperature and heat flux variation in a heat flow meter apparatus, latent heat of PCMs is calculated. Top and bottom plates are set to the same temperature. Temperatures and heat flow are measured at specific time intervals until equilibrium is reached allowing for enthalpy calculation.

- Non- homogenous samples

- Large sample sizes- (ex. $30 \times 30 \mathrm{~cm})$

Figure 2.3. Measurement of PCM thermal properties (Bruno et al., 2015; Shukla et al., 2012) 


\subsection{PCM application in buildings}

The large body of research available on PCM integration in buildings can be categorized into literature reviews and comprehensive studies on specific PCM applications in buildings. Multiple studies have presented extensive literature reviews on PCM products, their various applications and their impacts on building energy use and thermal comfort. Baetens et al. (2010), Soares et al. (2013), Tyagi and Buddhi (2005), Pasupathy et al. (2008a), Kuznik et al. (2011) are some of the reviewed studies with comprehensive background research on PCMs. These studies represent an important source of information on PCM usage, PCM characteristics and design considerations.

A complete overview of PCM products has been conducted by Baetens et al. (2010) with a focus on PCM inclusion in building materials such as gypsum, concrete, and insulation. Soares et al. (2013) have summarized multiple studies incorporating PCM materials in office and residential buildings that demonstrated positive impacts of PCMs on reducing overheating in summer. Fraser, (2009), have reviewed various PCM applications with a focus on commercial PCM products in the market and their availability. This study further provided recommendations for future improvements of PCM building applications. Heier et al. (2015), have outlined a comprehensive review of TES technologies including passive and active PCM applications in buildings. The study done by Heier et al. has particularly focused on the combination of TES applications and building type such as commercial and residential buildings.

The mechanism of PCMs is quite simple yet their optimal performance depends primarily on material specific properties in addition to certain environmental parameters. Certain design configurations must be implemented prior to PCM application to enhance the performance of these materials.

Climate characteristics, orientation, indoor boundary conditions, location of PCMs and the amount of PCMs used are all critical factors that affect PCM performance. Applying PCMs to buildings requires extensive and meticulous investigation of PCM properties in conjunction with building design parameters. This factor is clearly a part of all studies since designing PCMs is case specific which involves in-depth analysis of different PCM products and comparison of different determinants in order to select the most appropriate PCM application.

\subsubsection{Effect of Climate on PCM performance}

As stated earlier, the melting point of PCMs must correspond with its surroundings to be fully effective. The indoor thermal environment in buildings is primarily governed by the climate in which they are located and how it is controlled by the occupants. Studies that have focused on general PCM properties and their correlation with PCM operation show distinct behavior of PCMs in different climates in different seasons. A clear link exists between PCM performance and climate which has been investigated in multiple studies as a key variable to find the rate of PCM performance in different climatic situations.

Ascione et al. (2014) have investigated application of PCM wallboards in typical European office buildings. The study was conducted through a detailed parametric analysis which correlated different PCM melting points with climate variations in five Mediterranean cities. The study 
investigated performance of PCM wallboards in the cooling season which indicated a different behavior of PCM's in each different month of summer in each location.

Evola et al. (2013) have tested PCM wallboards in a light weight office building for thermal comfort improvements in summer in two different climates of Chambery in France and Catania in southern Italy. The PCM used had a nominal melting point of $27.6^{\circ} \mathrm{C}$, its suitability was assessed in relation to average weather variations. The city of Catania experiences severe temperatures and higher average temperatures in July and August in contrast to milder conditions in Chambery. Overall performance of the PCM and its impact on reducing overheating in summer was higher in the city of Chambery. The main reason was the more favorable operating conditions in Chambery compared to Catania. Results showed that $60 \%$ of the time the PCM was in liquid state in Catania, thus not preforming efficiently.

In buildings with mechanical conditioning, heating and cooling set points are the primary determinants of indoor boundary conditions. Childs and Stovall (2012) studied the relation of variable set points to PCM effectiveness. They have investigated a PCM wall system in two cities of Baltimore (moderate and wet climate) and Phoenix (hot and dry climate). The PCM wall system proved effective in shifting peak loads in both cities which is beneficial for overall demand reductions.

Vautherot et al. (2015) have studied the application of PCMs in a residential building in Auckland. The main variables of this study were heating set points and phase change temperature of a theoretical PCM, thus 5 different heating set points $\left(20-24{ }^{\circ} \mathrm{C}\right)$ and 5 different PCM melting ranges $\left(18-27^{\circ} \mathrm{C}\right)$ were parametrically analyzed. The results confirmed the higher effectiveness of PCMs with melting points near the heating and cooling set points.

In conclusion, by reviewing existing literature,no specific trends could be observed between climate types and PCM types as the results vary significantly in each research. The most important point is that designing PCMs is case specific and the conclusion in this regard is the direct link between indoor boundary conditions (set points) and that seasonal weather conditions with melting point of PCMs as interrelated factors.

While most studies have focused on the cooling season, some studies such as Fiorito (2014), Shilei et al. (2006), and Shrestha, (2012), have studied the effect of PCMs in the heating season. It was argued that applying PCMs could keep the warmth of spaces and reduce heat transfer to the outside air. In Canada, there are few studies on PCMs. One important study in Montreal investigated the application of PCM gypsum boards in an experimental solar test room in direct contact with the ambient weather in winter (Athienitis et al., 1997).

Multiple studies such as Entrop et al. (2011), Muruganantham et al. (2010), and Pasupathy et al. (2008b) have analyzed the performance of PCMs in buildings for one full year. Optimization of PCMs to operate for an entire year is quite difficult as studies have shown that PCMs with melting points selected based on the boundary conditions of summer will not be useful in other seasons. Even though the primary operation of PCMs is intended to reduce summer overheating and cooling energy use, their annual impact must not be neglected since they can play an important role in regulating temperatures in winter and shoulder periods.

An alternative approach was investigated by Diaconu and Cruceru (2010), through proposing a composite PCM wall system comprised of two different PCM integrated wallboards with two different melting points. One PCM was positioned near the exterior side of the envelope with a 
melting range appropriate to control the summer conditions, the second gypsum board was positioned on the inside lining of interior walls to control the radiant heat during winter. The results showed significant total cooling and heating energy savings as well as regulated temperatures inside the building enclosure throughout the year. Ascione et al. (2014), Entrop et al. (2011), Heim et al. (2016), Hoes and Hensen (2015), and Pasupathy and Velraj (2008) have also addressed the insufficient effectiveness of one PCM melting point to operate for an entire year and suggested more research on hybrid PCM systems.

\subsubsection{Positioning of PCM applications in buildings}

Another critical factor affecting PCMs' performance is the location of PCMs in building spaces and their position inside the building enclosure they are applied to, which affects the charge and discharge mechanism of PCMs. Integrating PCMs on inner surfaces of building applications is mentioned to have the highest impact on indoor temperatures as well as reduction of energy consumption (Rodriguez-Ubinas et al., 2013). However, applying PCMs on the exterior side of the building enclosure is also another option investigated which puts the PCM in contact with fluctuating ambient weather.

Heim and Wieprzkowicz (2016) quantified the amount of stored energy and the dynamics of melting and solidification cycles for PCMs while testing different positioning of a PCM layer in five different positions in thermal insulation of an external wall. Heim and Wieprzkowicz concluded that the best position for the PCM application was on the exterior side of the walls. Placing the PCM on the exterior controlled the temperature of the enclosure components directly. Conversely, Fiorito (2014) concluded that applying PCMs to interior walls and partitions was more beneficial compared to application of the same PCM to the exterior enclosure. Childs and Stovall (2012) have also mentioned the ineffectiveness of concentrating PCMs near the exterior side of their proposed wall system in contrast to distributing the PCM along the entire thickness of the wall.

While majority of studies reviewed here have focused on integration of PCMs in wallboards, there are multiple studies with different PCM applications. For instance, Pasupathy et al. (2008b) investigated the integration of an inorganic PCM into the roof of a sample unit, which resulted in a constant daily temperature of $27^{\circ} \mathrm{C}$ in the month of January. Muruganantham, et al. (2010), studied integration of an organic PCM into floors, walls, and ceiling. Narain et al. (2016), studied PCM enhanced concrete floors in a passive solar building. The outcomes showed that concrete floors with $13.5 \%$ PCMs had 35\% higher thermal capacity compared to regular concrete. According to Baetens et al. (2010), walls and ceilings are suitable for PCM integration as ceilings have obstructions and a larger heat transfer surface area. Applying PCMs to vertical surfaces is also beneficial for direct exposure to solar gains.

\subsubsection{Performance indicators for PCMs}

Evaluating the benefits of PCMs on indoor temperatures or energy use is done in various approaches, with majority of the literature focusing on the impact of PCMs on thermal comfort. Studies that evaluate the impact of PCMs on both thermal comfort and energy are limited. There is a lack of research on investigating both thermal comfort and energy consumption, specifically as these two elements are interrelated. Therefore, it is necessary to analyze both energy and 
comfort when integrating PCMs in buildings as performed by Athienitis et al. (1997), Kendrick and Walliman, (2007), and Vautherot et al. (2015) which investigated energy saving potential and changes in indoor temperatures by the incorporation of PCMs.

One retrofit study in Canada by Nikoofard, et al. (2014) has targeted PCM integration as a retrofit measure in the Canadian housing stock which showed great potential for adoption of such passive strategies. The focus of this study was on cost analysis and economic feasibility of PCMs in all provinces with different energy demands and climate conditions. The outcomes pointed to a $2.5 \%$ annual energy saving on average in all provinces, when a PCM with a melting point of $23^{\circ} \mathrm{C}$ was applied.

As discussed earlier, one of the key factors in high-rise apartments is the WWR, therefore drawing a connection between impacts of WWR on indoor air temperatures and PCM performance is an important area of research. In this study, WWR is the principal determinant of PCM effectiveness in high-rise apartments. As indicated by Kenisarin and Mahkamov, (2016), glazing ratio plays an important role in melting and solidification of PCMs, yet due to a lack of correlation between these two factors in the literature, the authors suggested this to be important for future research.

\subsection{Overview}

The initial gap in the research is the lack of available studies on thermal energy storage using PCMs as a possible energy retrofit measure, particularly in the Canadian climate. As designing PCMs is case specific and highly dependent on climate and building characteristics more evaluation and research is needed for PCM integration in this context. PCMs are an optimal solution for retrofit applications in high-rise apartments to enhance thermal capacity. PCMs do not reduce the floor size, they are installed quickly and have minimal intervention in a retrofit project. Considering the availability of thermal mass in the concrete structure of high-rise apartments, addition of PCMs would complement the thermal mass of concrete. Furthermore, PCMs have much higher heat capacity in narrow temperature ranges whereas in concrete much larger temperature swings are required for an effective sensible storage.

Energy retrofit in high-rise apartments was shown to be a beneficial approach to address energy efficiency in these buildings. Furthermore, the impact of radiant temperatures on regulating indoor environment and influencing energy use was emphasized. By reviewing previous studies on PCM incorporation in buildings and relating their findings to the initial research aims in this study, following points are derived, which serve as the final parameters.

1- This study aims to investigate thermal mass in the specific typology of high-rise residential buildings while the main categorization factor is the window to wall ratio. Including PCMs could be an effective solution to regulate temperatures and energy use in correlation with the existing glazing ratios which is a key factor affecting energy use in high-rise apartments.

2- PCMs are integrated in walls and ceilings of apartment units for retrofits. The inclusion of PCMs in ceilings is an unobtrusive method with low obstructions which will address the temperature stratification as a result of natural convection. Inclusion of PCMs in larger surface area in vertical wall surfaces would address direct solar exposure in the units. Additionally, 
majority of previous studies have observed acceptable PCM performance when applied to walls and ceilings surfaces.

3- The PCM application in this study is focused on interior surfaces and does not consider the exterior envelope of apartment units. Thus, positioning of all PCM applications is on the inside layer of interior walls and ceiling surfaces in close contact with the units' indoor environment. This positioning as mentioned in the literature is most beneficial since PCMs could directly affect the radiant temperatures of internal surfaces and ultimately the indoor environment.

4- As outlined earlier, the aim of this study is to provide year around thermal energy storage using PCMs. Optimizing PCM applications to have two melting points has been mentioned as the ultimate method for annual temperature control. More investigation on hybrid PCM systems is required to address both heating and cooling seasons.

5- Another gap in the research is regarding PCM evaluation, as majority of studies have focused on the impact of PCM applications on thermal comfort and energy consumption individually. However, these two factors are interrelated and the primary focus of this study is to address energy consumption changes by improving indoor temperatures in high-rise apartments. Thus, the impact of PCMs on both energy and thermal comfort indicators is considered.

Conducting research on PCM integration in buildings is a two-stage process which requires correlation of multiple factors. The first stage is design and optimization of PCMs to select an appropriate PCM application for the study. The second stage is the quantification and evaluation of how the selected system performs and affects indoor temperatures and energy consumption. Figure 2.4 shows the scope of this study and the most important parameters that must be considered in designing and evaluating PCM applications based on the literature.

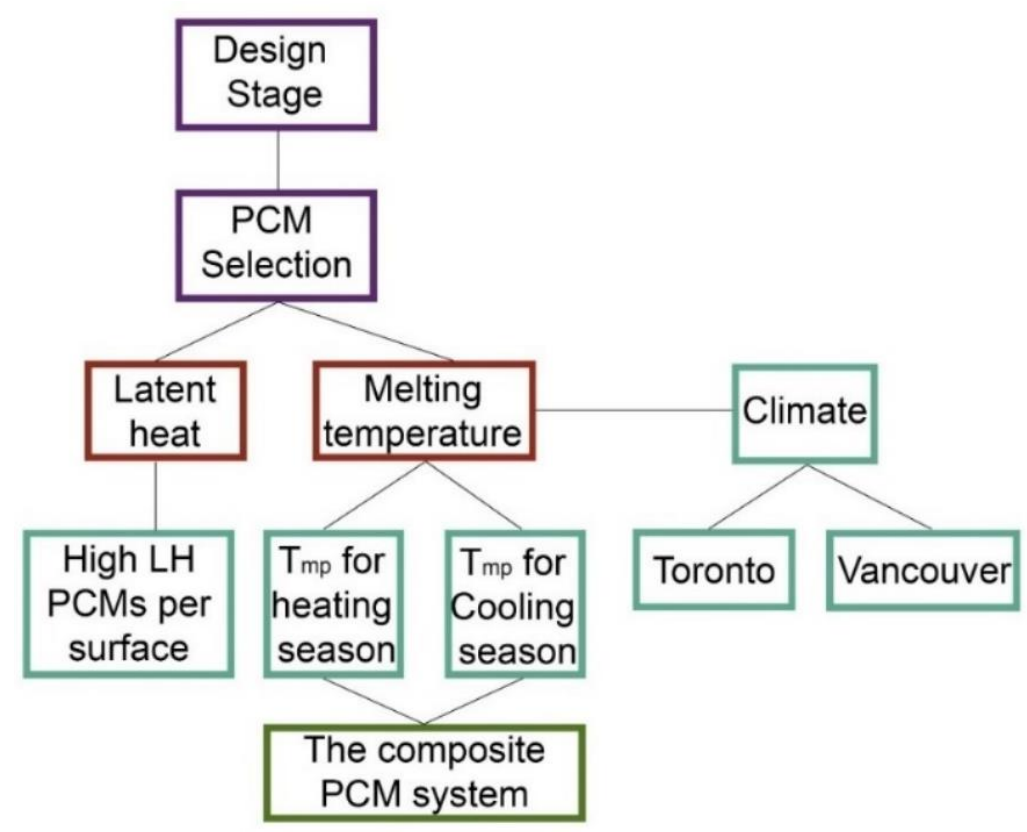

Figure 2.4. Parameters of interest for designing a PCM system 


\section{Chapter 3 : Methodology}

\subsection{Review of Previous studies}

There are several methods for assessing the behavior of PCMs in building applications and their overall impact. This chapter provides an overview of previous numerical and experimental studies. This step is critical in selecting the right approach for evaluating PCMs in this study.

\subsubsection{Numerical Studies}

Calculating heat transfer and heat storage capacity in PCMs is critical to predict their thermal performance in buildings. Modeling heat transfer in PCMs is carried out using mathematical models or whole building simulations. The moving boundary or "mushy zone" in PCMs created during the phase change makes the calculations challenging and difficult.

Two main calculation methods to solve the moving boundary problem of PCMs in use today are the "Heat capacity method" and the "Enthalpy method". In addition to these two main methods, multiple hybrid forms from the combination of enthalpy and heat capacity methods also exist.

- Heat Capacity Method: In this method, specific heat is a function of temperature calculated based on the heat flow rate at each temperature step from DSC results. In the heat capacity method, the melting temperature is considered to be a range and not a single melting point. Temperature change is described using the heat capacity.

- Enthalpy Method: This method is the most used mathematical method in the literature. The main aspect of the enthalpy method is the variation of specific heat and conductivity in relation to temperature. Enthalpy is considered as a temperature dependant variable. Enthalpy is a function of temperature and by replacing temperature and specific heat, enthalpy values are solved.

In multiple studies the heat capacity method has shown higher accuracy, however, as stated by Zhang et al. (2014), to calculate heat transfer for PCMs with narrow melting temperature range, the enthalpy method is more accurate. Mathematical models target heat transfer through PCMs and could assist in selecting the appropriate PCM system considering their thermal properties. In multiple studies, mathematical calculation models were the primary method of PCM assessment and PCM selection as shown in Table 3.1. Mathematical calculations were primarily used to select the most appropriate PCM product based on corresponding dynamic thermal characteristics of PCMs for the required conditions. Factors such as PCMs' location in the envelop, PCM's melting temperature suitability and amount of PCMs were some main parameters investigated for PCM optimization.

Even though multiple steps could be achieved with mathematical models, they are not sufficient in assessing the impact of PCMs on building energy consumption as multiple interrelated factors are involved in a building. In fact, in all studies mentioned in Table 3.1, other tests either simulation or experimental were conducted in support of the theoretical models. A notable factor regarding PCM-enhanced envelopes is their interaction with the indoor environment as well as other building systems and functions. Therefore, to accurately assess the implications of PCM 
applications on energy and indoor temperatures, a holistic context must be adopted which considers all building components and functional nature of the building.

Simulation programs use simplified versions of mathematical models to quantify the effects of PCMs on a whole building scale. The most frequently used simulation programs to assess PCMs, are: TRNSYS, Energy Plus, ESP-r, CoDyBa, PCM express, EDSL Tas and Wufi Plus.

Simulation programs enable evaluation and selection of PCM products based on their thermophysical characteristics using parametric analysis. The capability of parametric analysis is to consider different variables and PCM configurations for assessing the impacts of PCMs on indoor temperatures and energy use. The important advantage of simulations is evaluation of PCMs in a short time which is critical for PCM selection in the design phase.

Table 3.1. outlines studies using different simulation programs assessing several parameters that affect PCM performance. The main variables as shown in the table are concerning PCMs' melting temperature range, their concentration and the boundary conditions in the spaces. These factors are interrelated, specifically the indoor temperatures which are directly affected by the climatic situation. Positioning of PCM in indoor spaces, HVAC set points are other factors investigated in previous studies.

As presented in Table 3.1, Energy Plus is a popular simulation software in the literature for assessing PCMs. The reliability of Energy Plus has been validated in multiple studies which showed good agreement between experimental and simulation tests (Tabares-Velasco et al., 2012a). The principal method of calculation in Energy Plus for steady state heat transfer in surfaces is done through conduction transfer functions (CTFs). In the CTF method, all the inputs are constant for construction components which makes it impossible to calculate transient heat transfer in PCMs. Energy Plus models PCMs with conduction finite difference algorithm (ConFD) which discretizes walls, floors and ceilings into multiple nods. The ConFD algorithm is an implicit model which can be performed by either Crank-Nicholson or fully implicit algorithms to numerically solve the heat transfer problems (Tabares-Velasco et al., 2012a). The enthalpy method is the only method of calculation for PCMs in Energy Plus

However, using simulation programs has a major drawback as stated in the literature which is oversimplification in calculation algorithms. The analytical solutions consider only one melting point and do not consider the hysteresis and sub-cooling of PCMs. Moreover, thermal properties of the PCMs are regarded as constant throughout the phase transition, i.e. same enthalpy and melting point values in melting and solidification phase. These issues affect the daily cycle of phase transition in the test period, such as the number of times the PCMs stays in solid or liquid states, as explained by Evola et al. (2013).

Another important factor is the data input for thermophysical properties of PCMs in the software. As stated by Kosny (2015b) often limited and unreliable information is available for PCM products. Data inputs rely on thermal and physical data of the products derived from DSC results, this leads to significant inaccuracies as tests conducted by DSC are on pure PCMs and on very small sample sizes. Whereas actual building materials enhanced with PCMs are not homogenous and contain impurities and additives such as flame retardants or substances to increase durability. Many studies validate their numerical methodologies with separate experimental studies as done by Pasupathy et al. (2008b), Kuznik et al. (2009a), and Athienitis et al. (1997), mainly to remove such uncertainties in the simulation models. 
Table 3.1. Numerical studies on PCM applications in buildings

\begin{tabular}{|c|c|c|c|c|c|}
\hline Study & $\begin{array}{c}\text { PCM- } \\
\text { Application / } \\
\text { Melting point }\end{array}$ & $\begin{array}{l}\text { Methodology/ } \\
\text { Building Type }\end{array}$ & $\begin{array}{l}\text { Climate/ Testing } \\
\text { period }\end{array}$ & Parameters of study & Results \\
\hline \multirow[t]{2}{*}{$\begin{array}{l}\text { Ascione et al. } \\
(2014)\end{array}$} & $\begin{array}{c}\text { NG- } \\
\text { Gypsum } \\
\text { Wallboard }\end{array}$ & Sim. Energy Plus & $\begin{array}{l}\text { Ankara } 39.9^{\circ} \mathrm{N} \\
\text { Athens } 37.9^{\circ} \mathrm{N} \\
\text { Marseille } 43^{\circ} \mathrm{N} \\
\text { Naples } 40.8^{\circ} \mathrm{N} \\
\text { Seville } 37.4^{\circ} \mathrm{N}\end{array}$ & \multirow{2}{*}{$\begin{array}{l}\text { 1- Different melting } \\
\text { points } \\
\text { 2- Climate } \\
\text { 3- PCM location } \\
\text { 4- PCM thickness } \\
\text { 5- Natural and } \\
\text { mechanical ventilation }\end{array}$} & \multirow{2}{*}{$\begin{array}{l}\text { - The greatest energy saving was } \\
\text { observed with the highest thickness of } \\
3 \mathrm{~cm} \text { for the PCM. } \\
\text { - Highest cooling energy saving of } 7 \% \\
\text { was achived in Ankara with a } \mathrm{T}_{\mathrm{mp}}=29 \\
{ }^{\circ} \mathrm{C} \text { for the PCM. }\end{array}$} \\
\hline & $\mathrm{T}_{\mathrm{mp}}: 26^{\circ} \mathrm{C}$ & Office Building & Cooling Season & & \\
\hline \multirow[t]{2}{*}{$\begin{array}{l}\text { Evola et al. } \\
\text { (2013) }\end{array}$} & $\begin{array}{l}\text { NG - Gypsum } \\
\text { wallboard }\end{array}$ & Sim. Energy Plus & $\begin{array}{c}\text { Chambery } \\
45.3^{\circ} \mathrm{N} \\
\text { Catania } \\
37.5^{\circ} \mathrm{N} \\
\end{array}$ & \multirow{2}{*}{$\begin{array}{l}\text { 1- Effect of PCM on } \\
\text { thermal comfort }(2 \text { new } \\
\text { metrics introduced }) \\
\text { 2- Climate }\end{array}$} & \multirow{2}{*}{$\begin{array}{l}\text { - The study shows the selection } \\
\text { process and how the effectives of the } \\
\text { PCM depends on the matching } T_{m p} \\
\text { and climate. } \\
\text { - Lower peak temperature was } \\
\text { observed in the climate of Chambery }\end{array}$} \\
\hline & $\mathrm{T}_{\mathrm{mp}}: 22-28^{\circ} \mathrm{C}$ & Office Building & Cooling Season & & \\
\hline \multirow[b]{2}{*}{ Fiorito (2014) } & $\begin{array}{l}\text { Rubitherm } \\
\text { (4 Types) - } \\
\text { Walls }\end{array}$ & $\begin{array}{l}\text { Sim. Energy Plus } \\
\text { (Design Builder) }\end{array}$ & $\begin{array}{l}\text { Sydney } \\
33.52^{\circ} \mathrm{N}\end{array}$ & \multirow{2}{*}{$\begin{array}{l}\text { 1- Lightweight and well } \\
\text { insulated structures } \\
\text { 2- Location of PCM } \\
\text { inside the room } \\
\text { 3- Location of the PCM } \\
\text { within the wall } \\
\text { 4- Thickness of PCM } \\
\text { 5- Melting range }\end{array}$} & \multirow{2}{*}{$\begin{array}{l}\text { - PCMs placed in interior side of the } \\
\text { walls are more effective. } \\
\text { - PCM and insulation thickness } \\
\text { showed direct impact of PCMs on } \\
\text { discomfort hour reduction. }\end{array}$} \\
\hline & $\mathrm{T}_{\mathrm{mp}:}: 18-43^{\circ} \mathrm{C}$ & Office Room & One year & & \\
\hline \multirow{2}{*}{$\begin{array}{l}\text { Heim \& } \\
\text { Wieprzkowicz } \\
\text { (2016) }\end{array}$} & $\begin{array}{l}\text { Caprylic Acid- } \\
\text { PCM Insulation- } \\
\text { External Wall }\end{array}$ & $\begin{array}{l}\text { MAT. + } \\
\text { SIM. }\end{array}$ & \multirow{2}{*}{$\begin{array}{l}\text { Lodz } \\
51.4 \mathrm{oN}\end{array}$} & \multirow{2}{*}{$\begin{array}{l}\text { 1- Position of PCM in } \\
\text { the assembly } \\
2 \text { - Amount of stored } \\
\text { energy } \\
\text { 3- Melting temperatures }\end{array}$} & \multirow{2}{*}{$\begin{array}{l}\text { - The optimal scenario was concluded } \\
\text { when the PCMs are positioned on the } \\
\text { exterior and have } T_{\mathrm{mp}}: 20^{\circ} \mathrm{C} \\
\text { - Two metrics introduced: Amount of } \\
\text { stored energy and Dynamism of } \\
\text { charging and discharging which } \\
\text { proved suitable to assess the } \\
\text { positioning of PCM layers. }\end{array}$} \\
\hline & $\begin{array}{c}\mathrm{T}_{\mathrm{mp}}: \\
8.5,12,13.9,15 \\
8,19.5,20\end{array}$ & Office Unit & & & \\
\hline \multirow{2}{*}{$\begin{array}{l}\text { Kendrick } \\
\text { \& Walliman } \\
\text { (2007) }\end{array}$} & $\begin{array}{c}\text { Fatty Acid- } \\
\text { Gypsum drywall }\end{array}$ & SIM. APACHE & $\begin{array}{c}\text { NG [Hot Weather } \\
\text { pattern] }\end{array}$ & \multirow{2}{*}{$\begin{array}{l}\text { 1- Melting points } \\
\text { 2- Night ventilation } \\
\text { 3- Mechanical cooling } \\
\text { 4- PCM percentage } \\
\text { 5- Thermal conductivity }\end{array}$} & \multirow{2}{*}{$\begin{array}{l}\text { - Peak temperatures were reduced by } \\
4{ }^{\circ} \mathrm{C} \text { with } 80 \% \text { reduction in room } \\
\text { temperatures above } 24^{\circ} \mathrm{C} \\
\text { - Peak cooling load reduction varies } \\
\text { depending on variable set points. } \\
\text { - Night ventilation was critical }\end{array}$} \\
\hline & $\mathrm{T}_{\mathrm{mp}}: 21,22,23^{\circ} \mathrm{C}$ & $\begin{array}{c}\text { Commercial + } \\
\text { Residential }\end{array}$ & Cooling Season & & \\
\hline \multirow[b]{2}{*}{$\begin{array}{l}\text { Childs \& } \\
\text { Stovall } \\
\text { (2012) }\end{array}$} & $\begin{array}{l}\text { Paraffin- } \\
\text { Cllulose } \\
\text { insulation }\end{array}$ & SIM. HEATING 8 & $\begin{array}{l}\text { Phoenix } 33.4^{\circ} \mathrm{N} \\
\text { Baltimore } 39.2^{\circ} \mathrm{N}\end{array}$ & \multirow{2}{*}{$\begin{array}{l}\text { 1- Climate } \\
\text { 2- Location of PCM in } \\
\text { the wall } \\
\text { 3- Amount of PCM } \\
\text { 4- Wall orientation } \\
\text { 5- Temperature range } \\
\text { and set point } \\
\text { correlation }\end{array}$} & \multirow{2}{*}{$\begin{array}{l}\text { - Installing PCMs on south and west } \\
\text { walls showed to be more cost } \\
\text { effective. } \\
\text { - Lower savings in the cooling energy } \\
\text { were observed when PCMs were } \\
\text { applied to highly insulated walls. } \\
\text { - High effectiveness of PCMs in peak } \\
\text { load shifting was shown. }\end{array}$} \\
\hline & $\begin{array}{l}\mathrm{T}_{\mathrm{mp}}: 27^{\circ} \mathrm{C} \text { for } \\
\text { Phoenix } \\
\mathrm{T}_{\mathrm{mp}}: 25^{\circ} \mathrm{C} \text { for } \\
\text { Baltimore }\end{array}$ & Test Room & Annual & & \\
\hline \multirow[t]{2}{*}{$\begin{array}{l}\text { Rodriguez- } \\
\text { Ubinas et al. } \\
\text { (2013) }\end{array}$} & $\begin{array}{c}\text { NG } \\
\text { Drywall Panels }\end{array}$ & $\begin{array}{l}\text { SIM. PCM } \\
\text { Express }\end{array}$ & $\begin{array}{l}\text { Barcelona } 41^{\circ} \mathrm{N} \\
\text { Bilbao } 43^{\circ} \mathrm{N} \\
\text { Madrid } 40^{\circ} \mathrm{N} \\
\text { Seville } 37^{\circ} \mathrm{N} \\
\text { Soria } 41^{\circ} \mathrm{N} \\
\end{array}$ & \multirow[t]{2}{*}{$\begin{array}{l}\text { 1- Climate } \\
\text { 2- WWR } \\
\text { 3- Shading factor }\end{array}$} & \multirow{2}{*}{$\begin{array}{l}\text { - Increased thermal comfort hours by } \\
1000 \text { hours and lowered temperature } \\
\text { swings in all cases were observed } \\
\text { - Appropriate amount of PCMs could } \\
\text { effectively absorb excess heat from } \\
\text { large glazing ratios } \\
\text { - The effect of the used PCM was not } \\
\text { the same in all cities. }\end{array}$} \\
\hline & $\mathrm{T}_{\mathrm{mp}}: 26^{\circ} \mathrm{C}$ & $N G$ & Annual & & \\
\hline
\end{tabular}




\begin{tabular}{|c|c|c|c|c|c|}
\hline \multirow{2}{*}{$\begin{array}{l}\text { Virgone et al. } \\
\text { (2009) }\end{array}$} & $\begin{array}{c}\text { Energain } \\
\text { Walls + ceiling }\end{array}$ & SIM. CoDyBa & Lyon $45.7^{\circ} \mathrm{N}$ & \multirow{2}{*}{$\begin{array}{l}\text { 1- Pre and post retrofit } \\
\text { (with and without } \\
\text { insulation } \\
\text { improvement) } \\
\text { 2- PCM thickness }\end{array}$} & \multirow{2}{*}{$\begin{array}{l}\text { Applying PCMs with lower } \\
\text { thicknesses in large surface areas } \\
\text { performs better. }\end{array}$} \\
\hline & $\mathrm{T}_{\mathrm{mp}}: 21.7^{\circ} \mathrm{C}$ & Office Building & Summer & & \\
\hline \multirow{2}{*}{$\begin{array}{l}\text { Pasupathy et } \\
\text { al. (2008b) }\end{array}$} & $\begin{array}{l}\text { Salt hydrate } \\
\text { steel mesh }\end{array}$ & $\begin{array}{l}\text { MAT. Finite } \\
\text { Element method }\end{array}$ & Chennai $13.1^{\circ} \mathrm{N}$ & \multirow{2}{*}{$\begin{array}{l}\text { Calculating thermal } \\
\text { behavior of the PCM } \\
\text { system }\end{array}$} & \multirow{2}{*}{$\begin{array}{l}\text { Calculations used in the experimental } \\
\text { study }\end{array}$} \\
\hline & Tmp: $26-28{ }^{\circ} \mathrm{C}$ & Roof System & One Year & & \\
\hline \multirow{2}{*}{$\begin{array}{l}\text { Diaconu \& } \\
\text { Cruceru } \\
\text { (2010) }\end{array}$} & $\begin{array}{l}\text { NG- Wallboard } \\
\text { system }\end{array}$ & $\begin{array}{l}\text { MAT. Enthalpy } \\
\text { method }+ \\
\text { SIM. TRNSYS } \\
\end{array}$ & Bechar $31.6^{\circ} \mathrm{N}$ & \multirow{2}{*}{$\begin{array}{l}\text { 1- Double Layer PCM } \\
\text { 2- Different melting } \\
\text { points } \\
\text { 3- Thickness }\end{array}$} & \multirow{2}{*}{$\begin{array}{l}\text { - Model showed that the exterior PCM } \\
\text { layer controlled extreme outdoor } \\
\text { temperatures. } \\
\text { - Cooling energy saving had direct } \\
\text { relation with PCM thickness } \\
\text { - Annual energy saving of } 12.8 \% \text { was } \\
\text { observed. }\end{array}$} \\
\hline & $\mathrm{T}_{\mathrm{mp}}: 14-32^{\circ} \mathrm{C}$ & Test Room & One Year & & \\
\hline \multirow{2}{*}{$\begin{array}{l}\text { Kosny et al. } \\
(2012)\end{array}$} & $\begin{array}{l}\text { Methyl esther - } \\
\text { Insulation }\end{array}$ & $\begin{array}{l}\text { MAT. Heat } \\
\text { capacity method + } \\
\text { SIM. NG }\end{array}$ & $\begin{array}{c}\text { Warsaw } 52.2^{\circ} \mathrm{N} \\
\text { Marseille } 43.2^{\circ} \mathrm{N} \\
\text { Cairo } 30.1^{\circ} \mathrm{N}\end{array}$ & \multirow{2}{*}{$\begin{array}{l}\text { 1- Heat transfer and } \\
\text { heat storage capacity } \\
2 \text { - Climate }\end{array}$} & \multirow{2}{*}{$\begin{array}{l}\text { Calculations used in the experimental } \\
\text { study }\end{array}$} \\
\hline & $T_{\mathrm{mp}}: 19-25^{\circ} \mathrm{C}$ & $\begin{array}{l}\text { Wood frame wall } \\
\text { component }\end{array}$ & Cooling Season & & \\
\hline \multirow{2}{*}{$\begin{array}{l}\text { Athienitis et } \\
\text { al. (1997) }\end{array}$} & $\begin{array}{l}\text { Butyl Stearate - } \\
\text { Wallboard }\end{array}$ & $\begin{array}{l}\text { MAT. Enthalpy } \\
\text { Method }\end{array}$ & Montreal $45.5^{\circ} \mathrm{N}$ & \multirow{2}{*}{$\begin{array}{l}\text { Thermal performance } \\
\text { of the PMC wallboard } \\
\text { (transient heat transfer) }\end{array}$} & \multirow{2}{*}{$\begin{array}{l}\text { Comparison between mathematical } \\
\text { model and set of experimental tests } \\
\text { were in close agreement. }\end{array}$} \\
\hline & $T_{\mathrm{mp}}: 16-20.8^{\circ} \mathrm{C}$ & Test Room & Winter & & \\
\hline \multirow[b]{2}{*}{$\begin{array}{l}\text { Shrestha, } \\
(2012)\end{array}$} & Energain & SIM. WUFI Plus & Oslo $59.9^{\circ} \mathrm{N}$ & \multirow{2}{*}{$\begin{array}{l}\text { 1- Window type } \\
\text { 2- PCM location in the } \\
\text { space [wall - floor] }\end{array}$} & \multirow{2}{*}{$\begin{array}{l}\text { - Area designated for PCMs is an } \\
\text { important issue. } \\
\text { - Addition of PCMs in both walls and } \\
\text { floor showed the highest savings. } \\
\end{array}$} \\
\hline & $\mathrm{T}_{\mathrm{mp}}: 21.7^{\circ} \mathrm{C}$ & Residential Unit & $\begin{array}{l}\text { Cooling and Heating } \\
\text { Season }\end{array}$ & & \\
\hline \multirow{2}{*}{$\begin{array}{l}\text { Vautherot et } \\
\text { al. (2015) }\end{array}$} & $\begin{array}{l}\text { NG- } \\
\text { Gypsum Board }\end{array}$ & $\begin{array}{l}\text { SIM. Energy Plus } \\
\text { (Design Builder) }\end{array}$ & Auckland $36.8^{\circ} \mathrm{N}$ & \multirow{2}{*}{$\begin{array}{l}\text { 1- } 6 \text { melting points } \\
\text { 2- } 5 \text { heating Set points }\end{array}$} & \multirow{2}{*}{$\begin{array}{l}\text { - A strong connection was made } \\
\text { between indoor set point } \\
\text { temperatures and PCM performance. } \\
\text { - Savings in cooling energy were } \\
\text { much higher than savings in heating. }\end{array}$} \\
\hline & $\mathrm{T}_{\mathrm{mp}}: 18-27^{\circ} \mathrm{C}$ & Residential & Annual & & \\
\hline \multirow{2}{*}{$\begin{array}{l}\text { Hoes \& } \\
\text { Hensen } \\
(2016)\end{array}$} & $\begin{array}{l}\text { NG- Ceiling + } \\
\text { wall gypsum } \\
\text { board } \\
\end{array}$ & SIM. ESP-r & $\begin{array}{l}\text { Climate of } \\
\text { Netherlands }\end{array}$ & \multirow{2}{*}{$\begin{array}{l}\text { 1- One + two melting } \\
\text { point per zone } \\
\text { 2- Occupancy patterns } \\
\text { 3- Different melting } \\
\text { ranges }\end{array}$} & \multirow{2}{*}{$\begin{array}{l}\text { - Using two melting points in one zone } \\
\text { results in higher thermal comfort. } \\
\text { - Buildings with short periods of } \\
\text { occupancy are more beneficial }\end{array}$} \\
\hline & $\mathrm{T}_{\mathrm{mp}}: 16-28^{\circ} \mathrm{C}$ & Residential & Annual & & \\
\hline \multirow{2}{*}{$\begin{array}{l}\text { Pisello et al. } \\
\text { (2015) }\end{array}$} & $\begin{array}{l}\text { Theoretical - } \\
\text { PCM in roof } \\
\text { membrane }\end{array}$ & SIM. Energy Plus & Perugia $43.1^{\circ} \mathrm{N}$ & \multirow{2}{*}{$\begin{array}{l}\text { 1- Two different types } \\
\text { of roof membrane } \\
2 \text { - Insulation availability } \\
\text { on the roof }\end{array}$} & \multirow{2}{*}{$\begin{array}{l}\text { The effectiveness of PCMs added to } \\
\text { roof membrane is higher in reducing } \\
\text { energy when no roof insulation is } \\
\text { applied. }\end{array}$} \\
\hline & $\mathrm{T}_{\mathrm{mp}}: 26^{\circ} \mathrm{C}$ & Test room & Summer and Winter & & \\
\hline \multirow{2}{*}{$\begin{array}{l}\text { Kuznik et al. } \\
(2016)\end{array}$} & $\begin{array}{l}\text { NG- PCM } \\
\text { mortar on the } \\
\text { floor surface }\end{array}$ & $\begin{array}{l}\text { SIM. Dymola } \\
\text { Environment }\end{array}$ & Lyon $45.7^{\circ} \mathrm{N}$ & \multirow{2}{*}{$\begin{array}{l}\text { Evaluation of the } \\
\text { discrepancy between } \\
\text { actual enthalpy function } \\
\text { from an inverse method } \\
\text { with apparent enthalpy } \\
\text { function from DSC }\end{array}$} & \multirow{2}{*}{$\begin{array}{l}\text { A very accurate enthalpy } \\
\text { measurement is need for correct } \\
\text { simulation. }\end{array}$} \\
\hline & $\mathrm{T}_{\mathrm{mp}}: 26^{\circ} \mathrm{C}$ & $\begin{array}{l}\text { Single family } \\
\text { house }\end{array}$ & $\begin{array}{l}\text { Summer and Mid- } \\
\text { season case }\end{array}$ & & \\
\hline & NG: Informatior & Given & 1.: Whole Building $\varsigma$ & lation Study & T. Mathematical Study \\
\hline
\end{tabular}




\subsubsection{Experimental Studies}

Full-scale experimental tests are an important method to evaluate building envelope components containing PCMs as many factors affect the performance of these materials. Through full-scale field experiments, energy, thermal and hygrothermal performance data could be assessed in specific climates. The most frequently adopted test methods in the literature are whole building tests, outdoor test huts and indoor test rooms in labs or climate chambers. Whole building tests are occasionally conducted in actual buildings. Even though performing whole building tests is expensive and challenging, their main advantage is the possibility to study the behavior of PCMs in interaction with other building systems. This provides a real-life situation for monitoring how all building integrated technologies and systems work together and monitor the performance of PCM applications.

For instance, in an academic office building in Australia, PCM-enhanced concrete floors and PCM gypsum board ceilings were added to achieve a low energy office building. This building in Australia was monitored for two years to assess the performance of PCM integrated to ceiling and floors. The thermal storage capacity of the building was doubled which resulted in moderate indoor temperatures in both winter and summer within an acceptable thermal comfort range. Several energy efficient measures such as a well-insulated envelope, airtightness as well as passive measures such as natural ventilation and optimal daylighting and passive solar gains were also considered in the design of this building (Kosny, 2015c).

In contrast to whole building tests, test huts or test rooms are often preferred as they are less expensive and have an easier experimental implementation. Small scale test cells are more accessible and flexible in case of future modifications. Moreover, including a baseline model becomes possible which provides a significant opportunity to evaluate the performance of PCM integrated enclosures compared to a benchmark with conventional enclosures using actual data. Athienitis et al. (1997) and Kuznik and Virgone (2009) emphasize on the necessity of two cells tested under simultaneous conditions. Some experimental tests were performed in passive conditions where solar thermal energy and ambient weather activate the PCM components. While in some studies in addition to solar energy, mechanical systems were used to condition the test rooms. Changing configurations and test variables such as orientation or glazing ratio become possible by using such test rooms.

A comprehensive literature review on previous experimental tests is provided by Kenisarin and Mahkamov (2016), Kosny (2015c), and Sharma et al. (2009). The extensive review conducted by Kenisarin and Mahkamov (2016) was aimed to quantitatively compare previous studies and relate their obtained results. Kenisarin and Mahkamov have reviewed 17 individual full-scale tests, in different climate zones with a focus on heating dominated and cooling dominated areas. Kosny (2015c) have provided an overview of full-scale experimental tests with 19 different project examples including both whole building tests and test huts. 
Table 3.2 Experimental studies on PCM building applications

\begin{tabular}{|c|c|c|c|c|c|}
\hline Study & $\begin{array}{l}\text { PCM / } \\
\text { Application / } \\
\text { Melting point }\end{array}$ & $\begin{array}{l}\text { Type of } \\
\text { Test }\end{array}$ & $\begin{array}{c}\text { Location / Test } \\
\text { Period }\end{array}$ & $\begin{array}{c}\text { Parameters of } \\
\text { study }\end{array}$ & Results \\
\hline \multirow{3}{*}{$\begin{array}{l}\text { Cerón et al. } \\
\text { (2011) }\end{array}$} & Paraffinic Mix* & \multirow{3}{*}{$\begin{array}{l}\text { WB' - "Magic } \\
\text { House" } \\
\text { Solar House }\end{array}$} & \multirow{3}{*}{$\begin{array}{l}\text { Madrid, Spain, } \\
40.4^{\circ} \mathrm{N} \\
\text { Spring- }[60 \\
\text { days] }\end{array}$} & \multirow{3}{*}{$\begin{array}{l}\text { Direct and } \\
\text { indirect solar } \\
\text { exposure to the } \\
\text { floor surfaces }\end{array}$} & \multirow{3}{*}{$\begin{array}{l}\text { - Temperatures remain } 1.5-2 \mathrm{C} \text { above the } \\
\text { tiles with no PCM at night and regulate } \\
\text { daily temperatures up to } 4-10^{\circ} \mathrm{C} \text {. } \\
\text { - Shadow on PCM tiles facing direct } \\
\text { sunlight reduces their efficiency } \\
\text { considerably by } 6^{\circ} \mathrm{C} \text { lowered temperature } \\
\text { and less heat storage } \\
\text { - PCM tiles not receiving direct solar } \\
\text { radiation have smaller stored energy to } \\
\text { discharge when temperatures are lower at } \\
\text { night. }\end{array}$} \\
\hline & Clay floor tiles & & & & \\
\hline & $\mathrm{T}_{\mathrm{mp}}: 13-20.5^{\circ} \mathrm{C}$ & & & & \\
\hline \multirow{3}{*}{$\begin{array}{l}\text { Shossig et al. } \\
(2005)\end{array}$} & BASF* & \multirow{3}{*}{$\begin{array}{l}\text { WB- } \\
\text { Fraunhofer } \\
\text { façade } \\
\text { testing } \\
\text { facility }\end{array}$} & \multirow{3}{*}{$\begin{array}{l}\text { Germany } \\
\text { One year }\end{array}$} & \multirow{3}{*}{$\begin{array}{l}\text { 1- Shading } \\
\text { 2- Night } \\
\text { Ventilation } \\
\text { 3- Thickness of } \\
\text { PCM plaster }\end{array}$} & \multirow{3}{*}{$\begin{array}{l}\text { - Maximum temperature was reached one } \\
\text { hour later in the PCM wall } \\
\text { - Storage capacity was observed to be } \\
\text { overloaded in the unshaded scenario } \\
\text { leading to incomplete solidification. } \\
\text { - Number of hours above } 26^{\circ} \mathrm{C} \text { were } \\
\text { significantly reduced by addition of night } \\
\text { ventilation and shading in the day }\end{array}$} \\
\hline & $\begin{array}{l}\text { Plaster on } \\
\text { walls }\end{array}$ & & & & \\
\hline & $T_{\mathrm{mp}}: 24-27^{\circ} \mathrm{C}$ & & & & \\
\hline \multirow{3}{*}{$\begin{array}{l}\text { Athienitis et al. } \\
(1997)\end{array}$} & Butyl Setrate* $^{*}$ & \multirow{3}{*}{$\begin{array}{l}\mathrm{TR}^{2} \text {-Outdoor } \\
\text { test room }\end{array}$} & \multirow{3}{*}{$\begin{array}{c}\text { Montreal, } \\
\text { Canada, } 45.5^{\circ} \\
\mathrm{N} \\
\text { Winter }\end{array}$} & \multirow{3}{*}{$\begin{array}{l}\text { 1- Passive solar } \\
\text { gains } \\
2-\text { Validation of } \\
\text { numerical study }\end{array}$} & \multirow{3}{*}{$\begin{array}{l}\text { - Room temperatures reduced by } 4{ }^{\circ} \mathrm{C} \\
\text { - Application of PCMs in reducing } \\
\text { overheating in winter in highly glazed } \\
\text { spaces was shown to be effective }\end{array}$} \\
\hline & Wallboard & & & & \\
\hline & $\mathrm{T}_{\mathrm{mp}}: 16-20.8^{\circ} \mathrm{C}$ & & & & \\
\hline \multirow{3}{*}{ Cao et al. (2010) } & $\begin{array}{c}\text { Energain* } \\
\text { board }\end{array}$ & \multirow{3}{*}{ TR- hot box } & \multirow{3}{*}{$\begin{array}{l}\text { Laboratory- } \\
\text { Heating }+ \\
\text { cooling } \\
\text { conditions }\end{array}$} & \multirow{3}{*}{$\begin{array}{l}1 \text { - Air velocity on } \\
\text { surfaces } \\
\text { 2- Heating and } \\
\text { cooling rates }\end{array}$} & \multirow{3}{*}{$\begin{array}{l}\text { - Maximum air and surface temperatures } \\
\text { reduced by } 2{ }^{\circ} \mathrm{C} \\
\text { - Increase of air velocity on surfaces = } \\
\text { increase of PCM heat exchanges = better } \\
\text { PCM effect }\end{array}$} \\
\hline & Walls & & & & \\
\hline & $\mathrm{T}_{\mathrm{mp}}: 18-22^{\circ} \mathrm{C}$ & & & & \\
\hline \multirow{3}{*}{$\begin{array}{l}\text { Entrop et al. } \\
(2011)\end{array}$} & Micronal DS * & \multirow{3}{*}{$\begin{array}{c}\text { TR - Small } \\
\text { scale boxes }\end{array}$} & \multirow{3}{*}{$\begin{array}{l}\text { Enschede, } \\
\text { Netherlands, } \\
52.2^{\circ} \mathrm{N} \\
\text { One year }\end{array}$} & \multirow{3}{*}{$\begin{array}{l}\text { 1- Insulation } \\
\text { thicknesses } \\
\text { 2- Glazing types }\end{array}$} & \multirow{3}{*}{$\begin{array}{l}-16^{\circ} \mathrm{C} \text { reduction of maximum room } \\
\text { temperature and } 7{ }^{\circ} \mathrm{C} \text { increase in } \\
\text { minimum room temperature observed. } \\
\text { - Increasing thermal insulation lowers the } \\
\text { activation process of } \mathrm{PCMs} \\
\text { - The level of solar radiation coming in the } \\
\text { cells corresponds directly with the PCM } \\
\text { floor's effectiveness in different seasons. }\end{array}$} \\
\hline & Concrete floor & & & & \\
\hline & $\mathrm{T}_{\mathrm{mp}}: 22-25^{\circ} \mathrm{C}$ & & & & \\
\hline \multirow{3}{*}{$\begin{array}{l}\text { Kuznik and } \\
\text { Virgone } \\
\text { (2009a) }\end{array}$} & $\begin{array}{l}\text { Energain* } \\
\text { board }\end{array}$ & \multirow{3}{*}{$\begin{array}{l}\text { TR- Small } \\
\text { Scale test } \\
\quad \text { room }\end{array}$} & \multirow{3}{*}{$\begin{array}{l}\text { Laboratory- } \\
\text { Heating }+ \\
\text { cooling } \\
\text { conditions }\end{array}$} & \multirow{3}{*}{$\begin{array}{l}\text { Effect of } \\
\text { seasonal } \\
\text { temperature } \\
\text { changes }\end{array}$} & \multirow{3}{*}{$\begin{array}{l}\text { - In all the cases the PCM test cell had } 4.2 \\
{ }^{\circ} \mathrm{C} \text { lower indoor temperatures as result of } \\
\text { decreased overheating. } \\
\text { - No thermal stratification was observed in } \\
\text { the PCM test cell as opposed to } 1.3 \mathrm{C} \\
\text { temperature stratification between high } \\
\text { and mid points in the reference test cell. }\end{array}$} \\
\hline & Walls & & & & \\
\hline & $\mathrm{T}_{\mathrm{mp}}: 18-22^{\circ} \mathrm{C}$ & & & & \\
\hline \multirow{3}{*}{$\begin{array}{l}\text { Pasupathy et al. } \\
(2008 b)\end{array}$} & Salt hydrate** & \multirow{3}{*}{$\begin{array}{l}\text { TR- Outdoor } \\
\text { test rooms }\end{array}$} & \multirow{3}{*}{$\begin{array}{c}\text { Chennai, India, } \\
13.1^{\circ} \mathrm{N}\end{array}$} & \multirow{3}{*}{$\begin{array}{l}\text { 1- PCM panel } \\
\text { thickness } \\
\text { 2- Aiding PCM } \\
\text { solidification } \\
\text { through water } \\
\text { heat exchangers } \\
\text { 3- Validation of } \\
\text { numerical } \\
\text { analysis }\end{array}$} & \multirow{3}{*}{$\begin{array}{l}\text { - Roof temperature with the PCM was } \\
\text { higher for a longer period of time as a } \\
\text { result of lower conductivity of the PCM } \\
\text { roof } \\
\text { - Higher PCM ceiling temperature due to } \\
\text { lower heat removal from the PCM room } \\
\text { - Increasing thickness affects the } \\
\text { solidification process of the PCM. }\end{array}$} \\
\hline & $\begin{array}{l}\text { Embedded in } \\
\text { steel mesh for } \\
\text { the Roof }\end{array}$ & & & & \\
\hline & $\mathrm{T}_{\mathrm{mp}}: 26-28^{\circ} \mathrm{C}$ & & & & \\
\hline
\end{tabular}




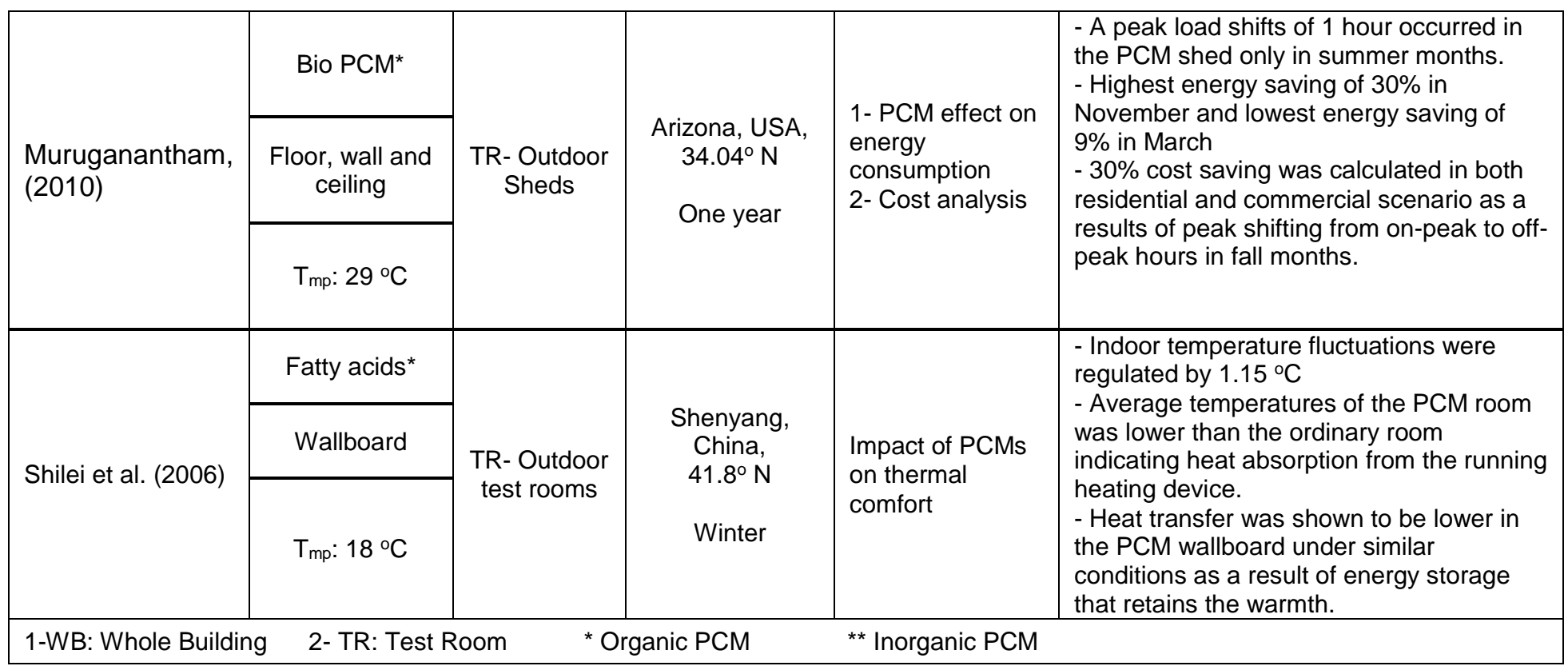

Athienitis et al. (1997), applied PCM immersed gypsum boards to walls of an outdoor passive solar test room in Montreal, Canada. This study was focused on the influence of PCM wallboards in mitigating overheating in direct gain buildings in winter. In addition, a numerical finite difference model was developed to analyze heat transfer in the PCM wallboards to later be compared with the experimental results. Wall gypsum boards were impregnated with $25 \%$ Butyl Stearate with a melting range of $16-20.8^{\circ} \mathrm{C}$. The outdoor test room used in this study was heated with a baseboard heater during the test period.

The results showed a close proximity between the numerical and experimental assessment with only $0.2^{\circ} \mathrm{C}$ difference in the results. Comparing a section of the wall without PCM and the PCM integrated walls, a significant drop was observed in the mean radiant temperatures. As a result, overall comfort conditions were improved by $4{ }^{\circ} \mathrm{C}$ reduction in maximum indoor air temperatures during the day. The impact of PCMs in reducing large solar gains was confirmed with the application of PCM drywalls on a large surface area.

Entrop et al. (2011) analyzed direct incorporation of PCMs into concrete floors in four synthetic plastic boxes, $1.1 \mathrm{~m} \times 0.7 \mathrm{~m} \times 0.7 \mathrm{~m}(\mathrm{I} \times \mathrm{w} \times \mathrm{h})$ in size. The PCM used for this study was Micronal PCM with a melting temperature $\left(T_{\mathrm{mp}}\right)$ of $23^{\circ} \mathrm{C}$ and a latent heat of $110 \mathrm{KJ} / \mathrm{Kg}$ which covered $5 \%$ of the total concrete floor. Test cells were positioned on an outdoor site exposed to passive solar radiation and ambient weather in the moderate climate of Netherlands for one year. The focus in such climate was to absorb thermal energy storage during the day to be released at night to increase temperatures. The main variables of the study were two insulation thicknesses and two different window types. These variables along with the addition of concrete PCM floors were monitored in relation to ambient weather and solar irradiance changes.

The results showed that PCM-enhanced concrete floors were easily activated by the passive solar radiation with no available mechanical system. The influence of solar radiation was further emphasized as the combination of triple glazing window with the PCM floor was useful in summer periods since high solar transmittance was controlled. Conversely, in April and 
September, the double glazed window was more beneficial to allow sufficient solar radiation to activate the PCMs in cooler temperatures. The overall results showed a reduction of maximum floor temperatures by $16^{\circ} \mathrm{C}$ and increase of minimum temperatures by $7^{\circ} \mathrm{C}$. Such increase in night temperatures was assumed to remove the need for auxiliary heating in shoulder seasons, particularly in first and last week of the heating season. Entrop et al. also indicated that the melting range of the selected PCM was more suitable for summer months. Nevertheless, it was suggested that if the transition temperature was between $19-22^{\circ} \mathrm{C}$, the PCM concrete floor would have been more effective in shoulder seasons.

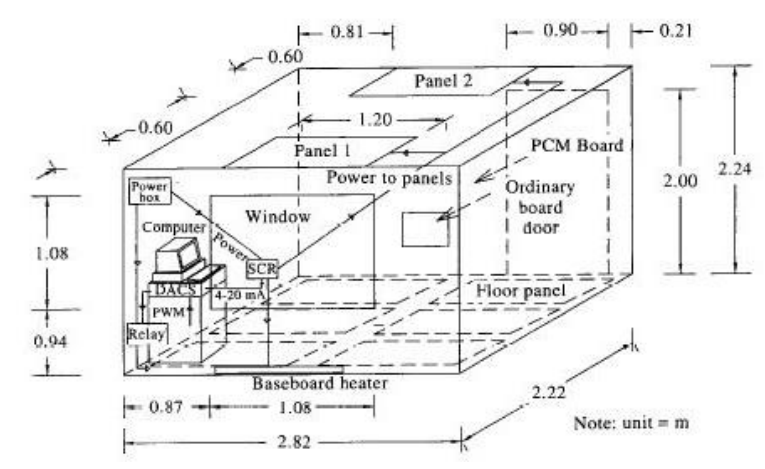

a) Athienities et al. (1997)- Test cell set up
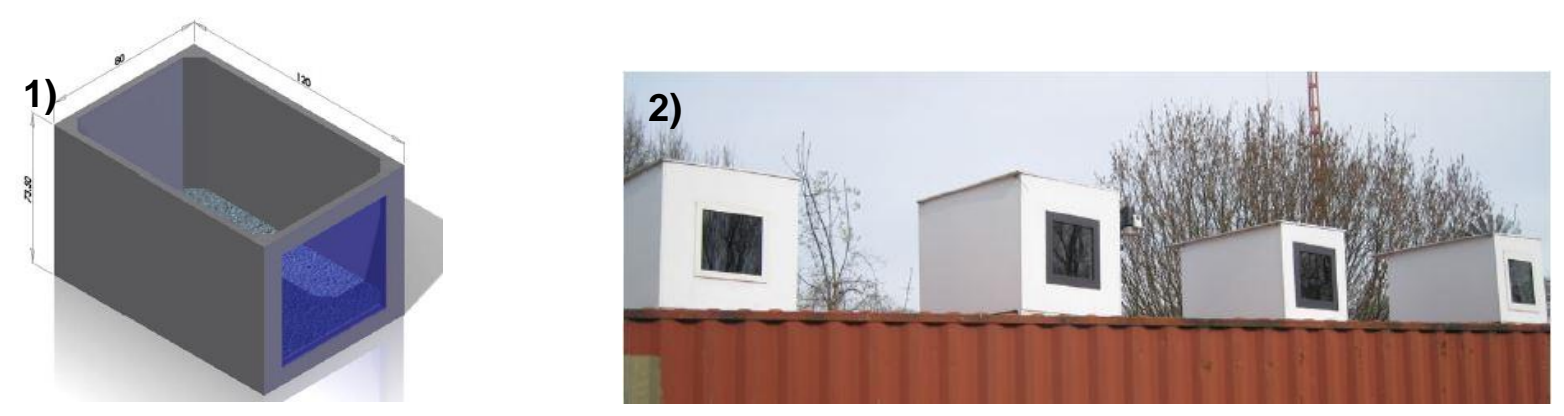

b) Entrop et al. (2011)- 1) Test cell layout; 2) Test cells on site

Figure 3.1. Figures from previous studies-1

In another test conducted by Muruganantham (2010), Bio PCM product was examined for wall, ceiling and floor configurations for a full calendar year in Tempe, Arizona. The Bio PCM used had a melting point of $29^{\circ} \mathrm{C}$ and latent heat of $219 \mathrm{KJ} / \mathrm{Kg}$. The test set up included two identical sheds constructed with conventional light wood frame with a pitched roof and vented attic space. Bio PCM was applied to all four walls, roof, and floor of one shed, while the other shed was reference. The sheds faced east and each was equipped with a window heat pump and a programmable thermostat. Researchers in this test also used air conditioning in early morning and late at night to speed the solidification process of the PCM.

The results of this test clearly drew a line between the impact of ambient temperature and solar radiation on the performance of PCMs. As the energy saving and cost analysis results showed, the performance of Bio PCM was linked to ambient weather transitions in the year. For instance, in March with very hot days and very cold nights, the cooling system had to operate more to provide the necessary condition for PCMs to operate. While in fall months both cost and energy 
consumption results were positive with $30 \%$ savings. It was stated that only on few days in winter the ambient temperatures fell in the range of the PCM product selected. Thus, energy saving and activation of the PCM on those periods were due to solar radiation entering the shed. Higher energy saving in winter was due to faster melting of PCMs by evening and their early solidification due to lower temperatures which released more heat to the environment lowering the demand for the heat pump.

Kuznik and Virgone (2009a) performed a full-scale test study in a test room called the MINIBAT under controlled thermal and radiative effects shown in Fig. 3.2-b. The PCM product tested was the Energain board $\left(T_{m p}\right.$ of $21.7^{\circ} \mathrm{C}$ ), which was applied to three walls of the test cell. An active system of air volume surrounded the cell on all sides with regulated constant temperature. $A$ solar simulator was used to allow short wave radiation into the cells. Three different days were tested: a winter day, a summer day and a mid-season day. To test the PCMs in these three scenarios the temperature of the climate chamber varied to corresponding weather conditions of each period. In the summer case, night cooling was provided to the test cell, and in the winter day case, a heating system was installed in the cell. Surface temperatures, as well as air temperatures inside the test cell, were measured.

In the summer case, maximum air temperatures were reduced by $3.9^{\circ} \mathrm{C}$, while night temperatures were slightly increased due to incorporation of night ventilation. A similar pattern was observed in the mid-season case with higher reduction in high peak air temperatures. Moreover, in all cases, it was confirmed that the impact of the Energain PCM was higher on changing surface temperatures in the side walls compared to the North wall facing the window of the test cell. This research concluded on the importance of radiative surface temperatures affecting room temperatures. The capability of the Energain board was shown in maintaining acceptable thermal comfort range in the room while surface temperatures were lower compared to reference case due to heat storage.

The performance of an inorganic eutectic PCM storage system was investigated using simulation and experimental tests in the city of Chennai, India by Pasupathy et al. (2008b). An outdoor experimental set up consisting of two identical test cells was constructed with dimensions of $1.2 \mathrm{~m} \times 1.2 \mathrm{~m} \times 2.4 \mathrm{~m}(\mathrm{I} \times \mathrm{w} \times \mathrm{h})$, allowing for comparison of PCM test cell and a conventional test cell. The PCM used in this study was salt hydrate with a melting temperature range of $26-28{ }^{\circ} \mathrm{C}$, and latent heat of $188 \mathrm{KJ} / \mathrm{Kg}$. PCMs were embedded in a $2.5 \mathrm{~cm}$ stainless steel panel which was placed on the roof in between the bottom concrete slab and the roof slab. The mechanism of the PCM test cells involved water pipes running through the concrete slabs acting as heat exchangers in summer nights. The main variables were thickness of the PCM panel, ambient condition changes and heat transfer changes on the outer surface.

The experimental results showed that the maximum temperature of the roof surface was higher in the PCM test cell due to lower conductivity of the melted PCMs which decreased heat transmission to the room. The investigation of three different PCM panel thicknesses presented that $2.5 \mathrm{~cm}$ PCM panel was sufficient to prevent overheating in the winter months and showed acceptable results in summer. A $1 \mathrm{~cm}$ panel showed considerable fast melting and increased surface temperatures, in contrast to a $3 \mathrm{~cm}$ PCM panel that could not solidify and release the heat at night in summer. The study further showed that inclusion of water heat exchangers to address night cooling required extensive amounts of water which could be a challenge in summer months. Consequently, the authors proposed using two PCM products in the roof panel with different melting points as a potential approach. 

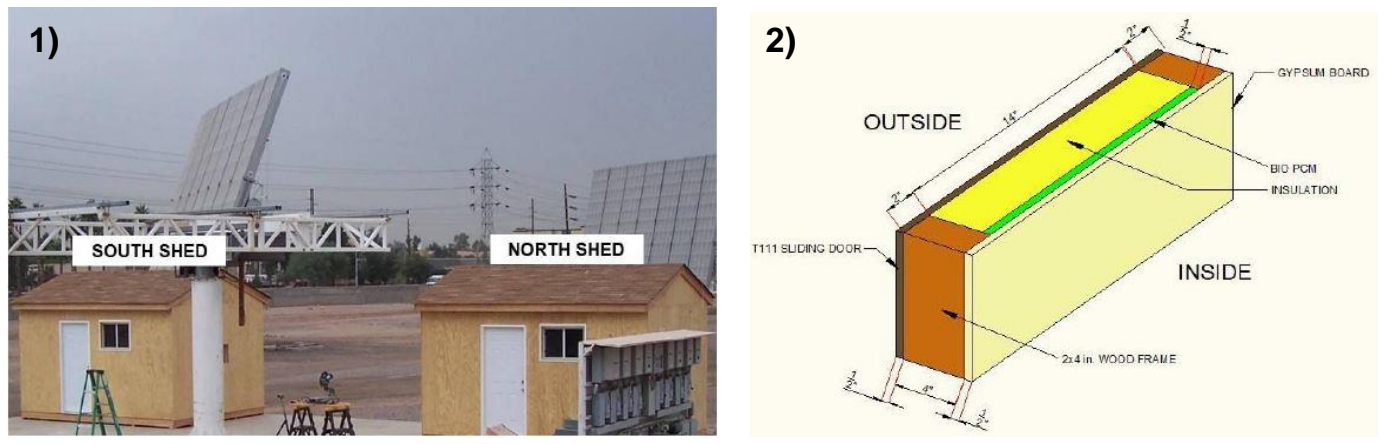

a) Muruganantham, (2010)- 1) Test Sheds; 2) Wall cross section with PCM application
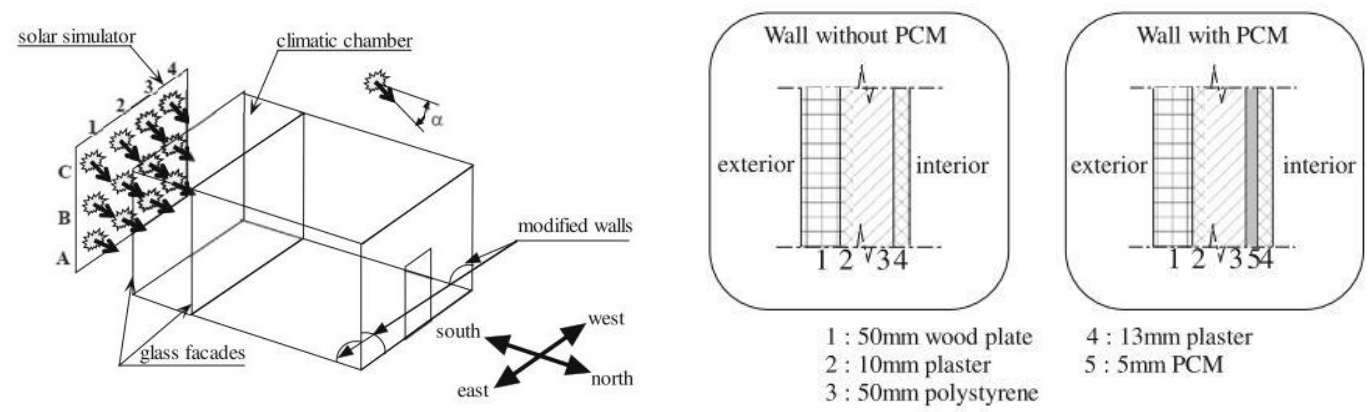

b) Kuznik et al. (2009a)- Diagram of the test cell; Wall compositions
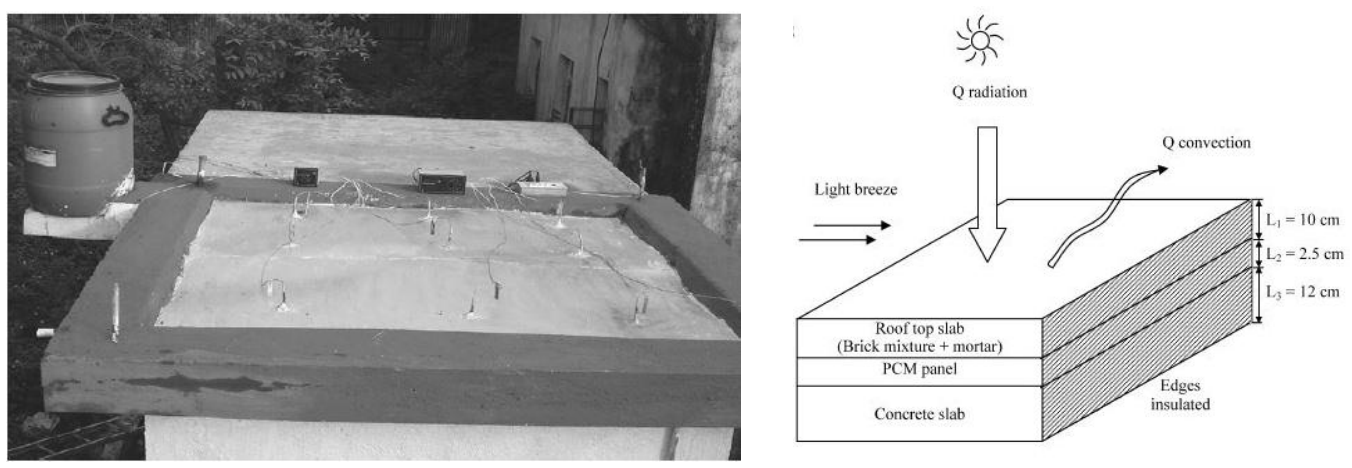

C) Pasupathy et al. (2008a)- Test cell roof slabs; Roof Layers

Figure 3.2. Figures from previous studies-2

Key points derived from reviewing research methodologies in the literature are:

- Parametric analysis using simulation software on a whole building scale is a useful approach to test different variables and their relation to how PCMs impact indoor temperatures;

- A detailed overview of how PCM systems work is best analyzed by experimental tests;

- Adoption of two test cells specifically having a benchmark cell is an important step to understanding the behavior of PCM products;

- A direct link between PCM performance and diurnal ambient weather changes was shown. Thus, a longer period of testing with varied temperature changes is necessary 


\subsection{Research methodology}

Based on the literature, to fully investigate the potential of PCM integration, this research aims at adopting both numerical and experimental analysis. It is necessary to perform both methods to holistically analyze the impact of PCMs on a whole building and a detailed scale. As noted earlier, a year around latent thermal energy storage using a composite PCM system for walls and ceilings of high-rise apartment units will be investigated. The PCM system is targeted for the interior layer of walls and ceiling as applying PCM layers in direct contact with indoor environment to absorb the excess load in spaces generated by internal or solar gains.

The aim of this research is to focus on commercial PCM products specifically organic microencapsulated PCMs for their longer lifespan, stability, and congruent melting. Currently, organic paraffinic PCMs dominate the market and represent a higher share. Several available organic PCM products for wall and ceiling applications were identified and reviewed based on their physical and thermal properties as specified in Table 3.3. As evident, there is a broad range of products currently in the market with different melting points and latent heat values as well as different applications. PCMs could be applied to building envelopes in different forms, however, the focus of this study is on PCMs that could be directly applied to existing interior layers of the envelope for ease of implementation in retrofits.

Table 3.3. List of commercial PCM products in the market

\begin{tabular}{|c|c|c|c|c|c|c|c|c|c|}
\hline Product & Manufacturer & Application & $\begin{array}{c}\text { PCM } \\
\text { Type - } \\
\text { Amount } \\
\left(\mathrm{Kg} / \mathrm{m}^{2}\right)\end{array}$ & $\begin{array}{c}\text { Melting } \\
\text { temperature } \\
\left({ }^{\circ} \mathrm{C}\right)\end{array}$ & $\begin{array}{c}\text { Latent } \\
\text { Heat } \\
(\mathrm{KJ} / \mathrm{Kg})\end{array}$ & $\begin{array}{c}\text { Specific } \\
\text { heat } \\
(\mathrm{KJ} / \mathrm{Kg} . \\
\left.{ }^{\circ} \mathrm{C}\right)\end{array}$ & $\begin{array}{l}\text { Conductivity } \\
\text { (W/m.K) }\end{array}$ & $\begin{array}{l}\text { Dimensions } \\
\text { (cm) }\end{array}$ & $\begin{array}{l}\text { Weight } \\
\left(\mathrm{Kg} \cdot \mathrm{m}^{2}\right)\end{array}$ \\
\hline $\begin{array}{l}\text { Alba® } \\
\text { Balance }\end{array}$ & $\begin{array}{l}\text { Rigips- Saint } \\
\text { Gobain }\end{array}$ & $\begin{array}{c}\text { Plaster } \\
\text { blocks } \\
\text { (Ceiling + } \\
\text { walls) }\end{array}$ & $\begin{array}{c}\text { Micronal } \\
3 \\
(13.5 \%)\end{array}$ & $\begin{array}{l}23 \\
25\end{array}$ & 110 & 1.16 & 0.27 & $50 \times 100 \times 2.5$ & 23 \\
\hline $\begin{array}{l}\text { Comfort } \\
\text { Board }\end{array}$ & Knauf & $\begin{array}{l}\text { Plaster wall } \\
\text { board }\end{array}$ & $\begin{array}{c}\text { Micronal } \\
3.3 \\
(30 \%) \\
\end{array}$ & 23 & 110 & 1.2 & 0.23 & $125 \times 200 \times 1.2$ & 11 \\
\hline $\begin{array}{l}\text { Weber.Mur } \\
\text { Clima® }\end{array}$ & Saint Gobain & $\begin{array}{l}\text { Machine } \\
\text { applied } \\
\text { Plaster }\end{array}$ & Micronal & $\begin{array}{l}21-23 \\
23-26 \\
\end{array}$ & $N G$ & $N G$ & 0.19 & $1 \mathrm{~cm}$ thick & 13 \\
\hline $\begin{array}{l}\text { Eco } \\
\text { Building } \\
\text { Boards }\end{array}$ & Weebly & $\begin{array}{l}\text { Clay plaster } \\
\text { wall panels }\end{array}$ & $\begin{array}{l}\text { Micronal } \\
3(20 \%)\end{array}$ & 26 & 132 & $N G$ & $N G$ & $62 \times 125 \times 2.2$ & 15 \\
\hline Cool Zone & Armstrong & $\begin{array}{l}\text { Metal Ceiling } \\
\text { tiles }\end{array}$ & $\begin{array}{c}\text { Micronal } \\
6(25 \%) \\
\end{array}$ & 23 & 82 & $N G$ & $N G$ & $60 \times 60 \times 2.5$ & 25 \\
\hline $\begin{array}{l}\text { Energain® } \\
\text { Thermal } \\
\text { mass panel }\end{array}$ & DuPont & $\begin{array}{l}\text { Wall and } \\
\text { Ceiling } \\
\text { panels }\end{array}$ & $\begin{array}{c}\text { Paraffin } \\
\text { wax } \\
14.7 \\
(60 \%) \\
\end{array}$ & 21.7 & 70 & 2.5 & $\begin{array}{c}0.18 \text { - Solid } \\
0.14 \text { - Liquid }\end{array}$ & $100^{\star} 120 * 0.5$ & 4.5 \\
\hline $\begin{array}{l}\text { ENRG } \\
\text { Blanket }^{T M}\end{array}$ & $\begin{array}{l}\text { Phase } \\
\text { Change } \\
\text { Energy } \\
\text { Solutions }\end{array}$ & $\begin{array}{l}\text { Wall, Ceiling, } \\
\text { floor mats }\end{array}$ & $\begin{array}{c}\text { Bio } \\
\mathrm{PCM}^{\mathrm{TM}}\end{array}$ & $\begin{array}{l}23 \\
25 \\
27\end{array}$ & $\begin{array}{l}165- \\
200\end{array}$ & 2.1 & 0.2 & $40 \times 120 \times 1.5$ & 2.7 \\
\hline $\begin{array}{l}\text { Therma } \\
\text { cool }\end{array}$ & $\begin{array}{c}\text { Datum Phase } \\
\text { Change }\end{array}$ & $\begin{array}{l}\text { Ceiling Tiles } \\
\text { Wall Panels } \\
\end{array}$ & Micronal & 22 & 25.9 & $N G$ & 0.88 & $60 \times 60 \times 2.5$ & 25 \\
\hline $\begin{array}{l}\text { Thermal } \\
\text { Core® }\end{array}$ & $\begin{array}{l}\text { National } \\
\text { Gypsum }\end{array}$ & $\begin{array}{l}\text { Ceiling and } \\
\text { wall boards }\end{array}$ & Micronal & $\begin{array}{l}23 \\
26 \\
\end{array}$ & 110 & 1.2 & $N G$ & $120 \times 240 \times 1.2$ & 10.2 \\
\hline
\end{tabular}


The majority of reviewed studies have focused on pure PCMs or reference PCMs introduced for the purpose of their studies with theoretically high latent heat values or high PCM percentage for maximum effectiveness. However, as PCMs get applied to building materials such as gypsum or concrete, they are mixed with flame retardants and other elements that are required by building regulations. This changes the thermophysical properties of these materials and therefore affects their performance. Thus, it is essential to portray the reality of available products versus possibilities. Evaluating the performance of market available PCM products could further lead to future research on improving PCM building applications.

Through further investigation and comparison, two products from the above list were selected as possible options for this study. Bio PCM and Energain are primarily selected for their high latent heat values and their corresponding melting ranges to the climate of Toronto and Vancouver. The applicability of these products to retrofit projects and their availability in the Canadian market were other factors for this selection. The effectiveness of these two products has been tested in previous studies presented in Tables 3.1 and 3.2.

- Energain ${ }^{\circledR}$ PCM Panels: Made of an ethylene based polymer mixed with microencapsulated paraffin PCM wax is wrapped in thin layers of aluminum foil with a thickness of $0.5 \mathrm{~cm}$. These panels could be directly applied behind the drywall or ceiling tiles. The melting point of this product is $21.7^{\circ} \mathrm{C}$, with a high latent heat and high concentration of $60 \%$ PCM per panel. This product has been tested in multiple studies and has been applied to actual buildings in different climate conditions with acceptable results both in heating and cooling seasons (Gilbert and Koster, 2010).

- $\quad$ ENRG Blanket: Contains BioPCM ${ }^{\mathrm{TM}}$, embedded in thin foil based pouches with dimensions of $1.5 \times 1.5 \mathrm{~cm}$. Each mat contains 60 PCM blocks. Bio PCM ${ }^{\mathrm{TM}}$ is a biobased material made out of by-products of palm oil, coconut, and soy. The Bio PCM mats could be directly placed above ceiling tiles or fastened to wall studs behind drywall finishing. This product has three melting points of 23,25 and $27^{\circ} \mathrm{C}$ with varying storage capacities (Phase Change Energy Solutions, 2016).
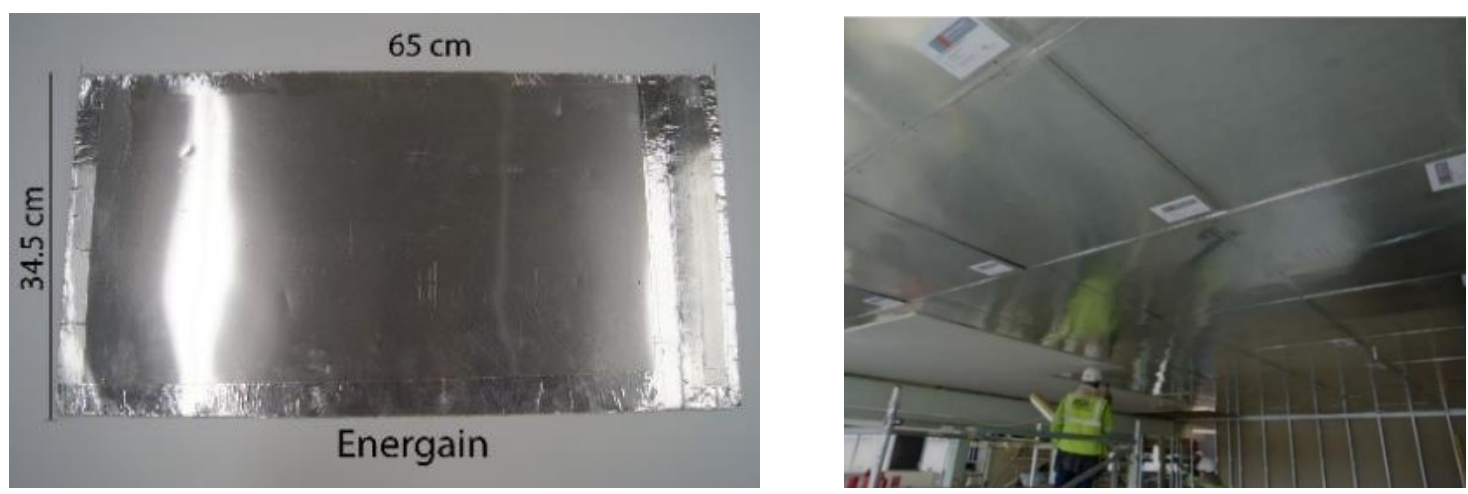

a) Energain PCM Panels (Gilbert and Koster., 2010) 

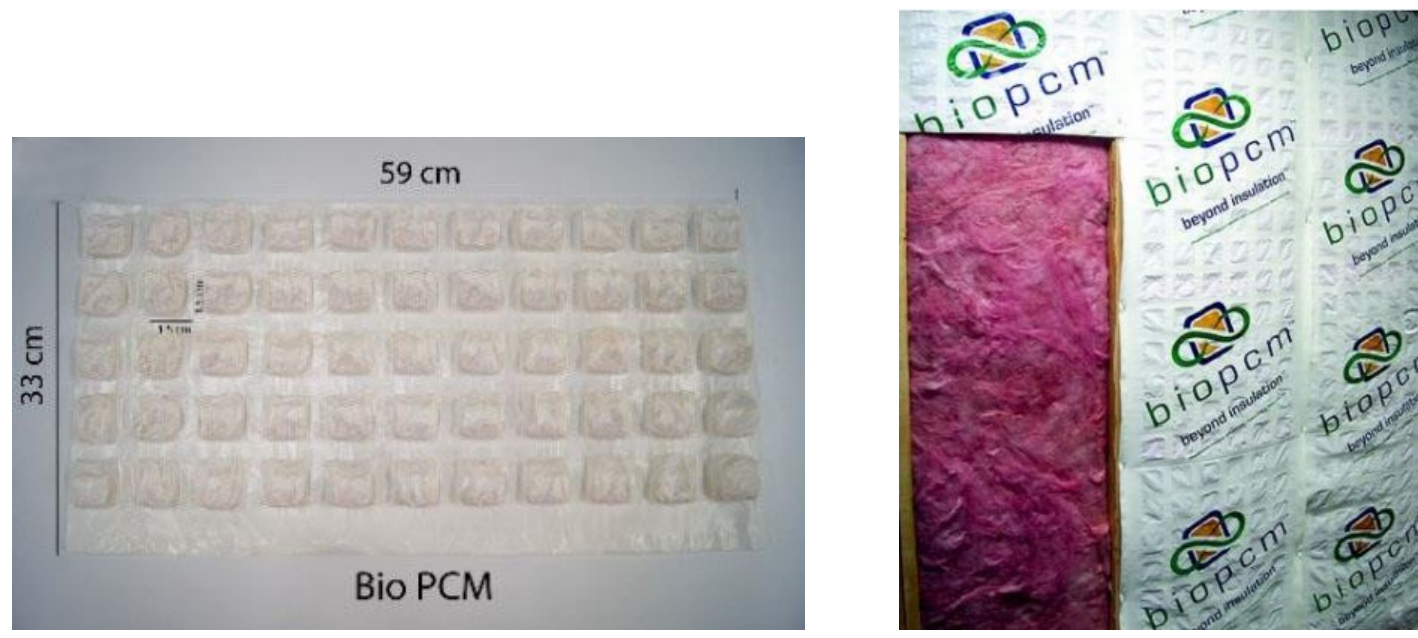

b) Bio PCM- (Phase Change Energy Solutions, 2016)

Figure 3.3. Selected PCM products

As presented in Table 3.3, integrating PCMs into porous building materials allows for a small percentage of PCM addition- maximum 30\% due to structural reasons. Conversely, regarding the two selected products for this study, as they are individual boards they contain higher PCM percentage per weight which makes them attractive options. Heat storage capacity of Energain and Bio PCM is compared to typical building materials to better illustrate the high impact of latent heat storage provided by PCMs. The effective mass equivalents presented in Figure 3.4 shows the higher heat storage capacity of PCMsin these two products. As the figure demonstrates, in a temperature profile of $18-24{ }^{\circ} \mathrm{C}$, concrete offers about $15.8 \%$ of the energy storage that is offered by $5 \mathrm{~mm}$ of Energain. Similarly, the heat storage capacity of the $15 \mathrm{~mm}$ Bio PCM is $74.4 \%$ higher than that of concrete within a $6^{\circ} \mathrm{C}$ temperature change. The higher thermal energy storage in much smaller density and thickness in Energain and Bio PCM is due to their high latent heat and specific heat values leading to large sensible and latent heat storage in narrow temperature ranges. Combining these two products in a composite PCM system could show a high potential for energy and thermal comfort improvements.

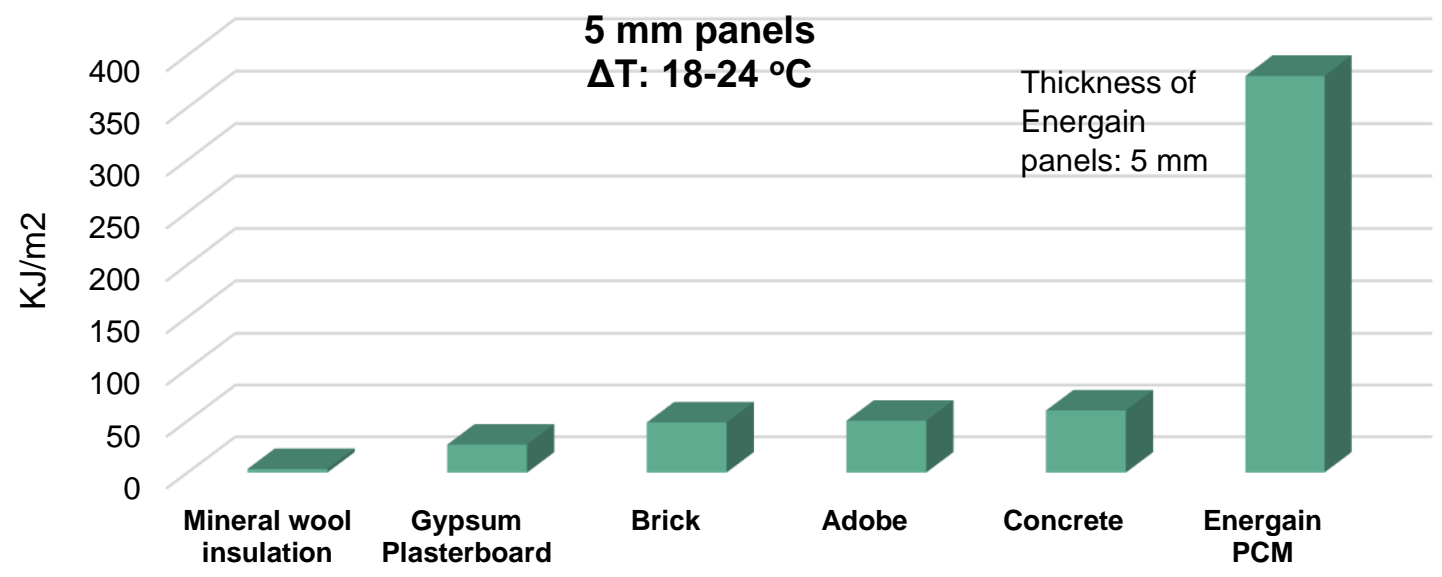




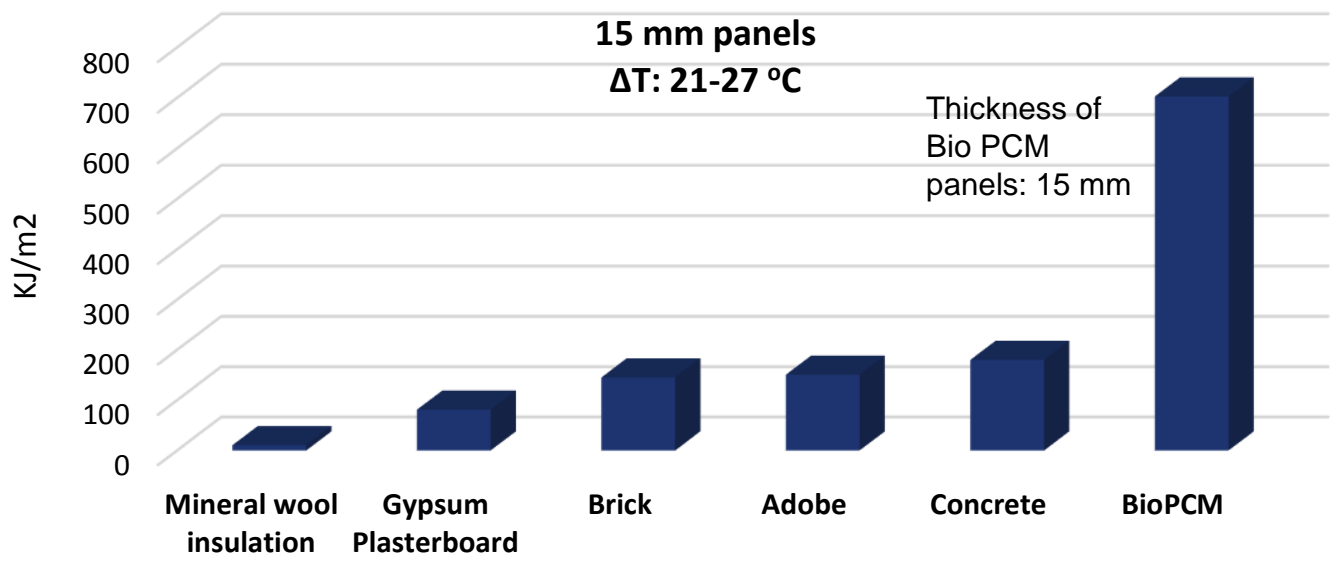

Figure 3.4. Effective mass equivalents

Regarding thermal characteristics of the two selected products, Energain PCM panels have melting points in the range of indoor spaces in winter months. Bio PCM panels with $T_{m p}=23^{\circ} \mathrm{C}$ and $T_{\mathrm{mp}}=25^{\circ} \mathrm{C}$ are compatible to indoor conditions in summer months in Canada. The nominal melting points of the selected products as presented in Table 3.3 represents the peak of the melting curve as shown in Fig. 3.5.

The difference between the melting temperature and the freezing temperature in the Energain product characterizes the hysteresis of the material. As presented, the overall melting process takes place in the range of $18-22{ }^{\circ} \mathrm{C}$. Similar observation on Energain's hysteresis was made by Kuznik and Virgone (2009a).

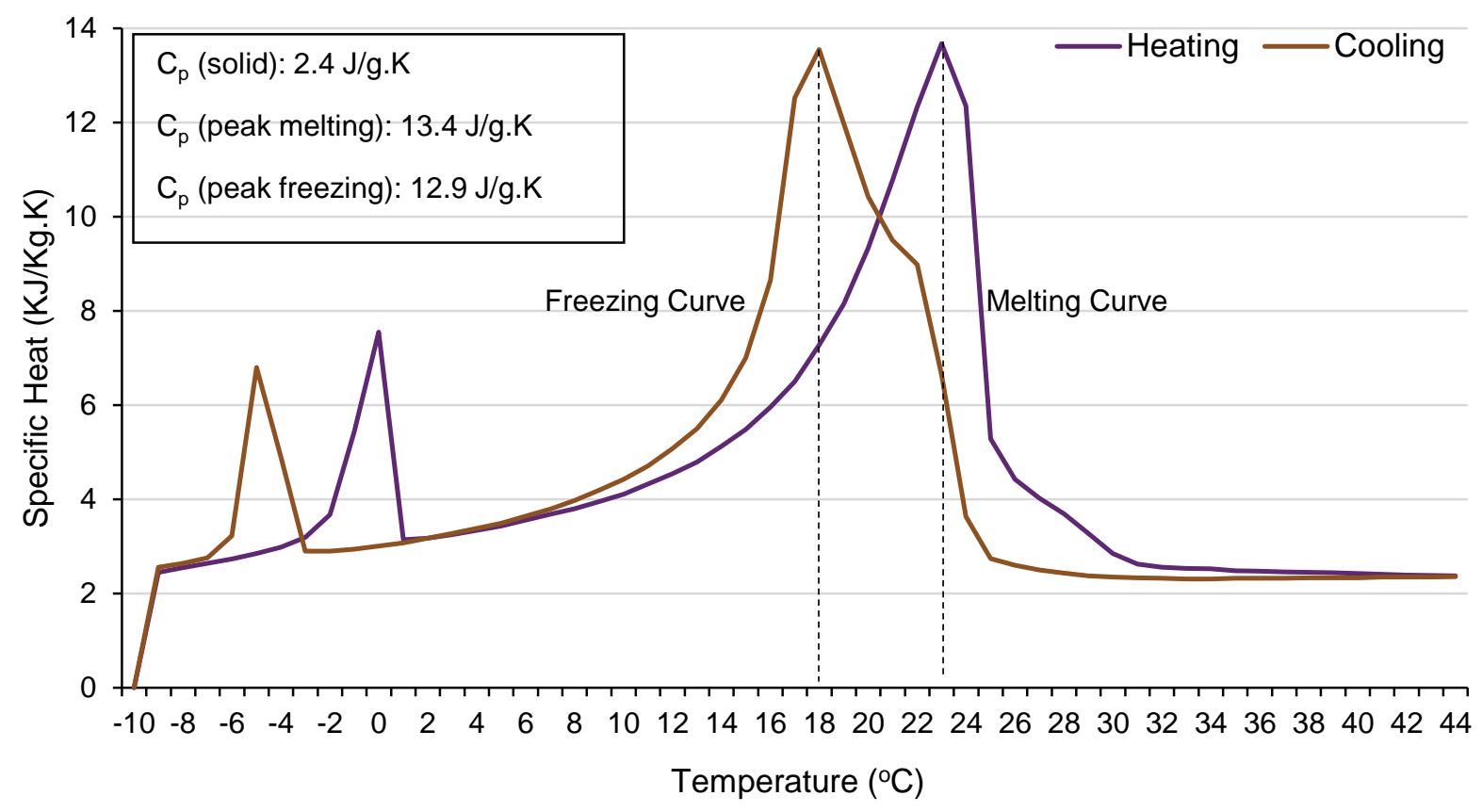

a) Specific heat of the Energain panels -DSC tests $\left(0.05 \mathrm{k} / \mathrm{min}^{-1}\right)$ - (Graph provided by DuPont) 

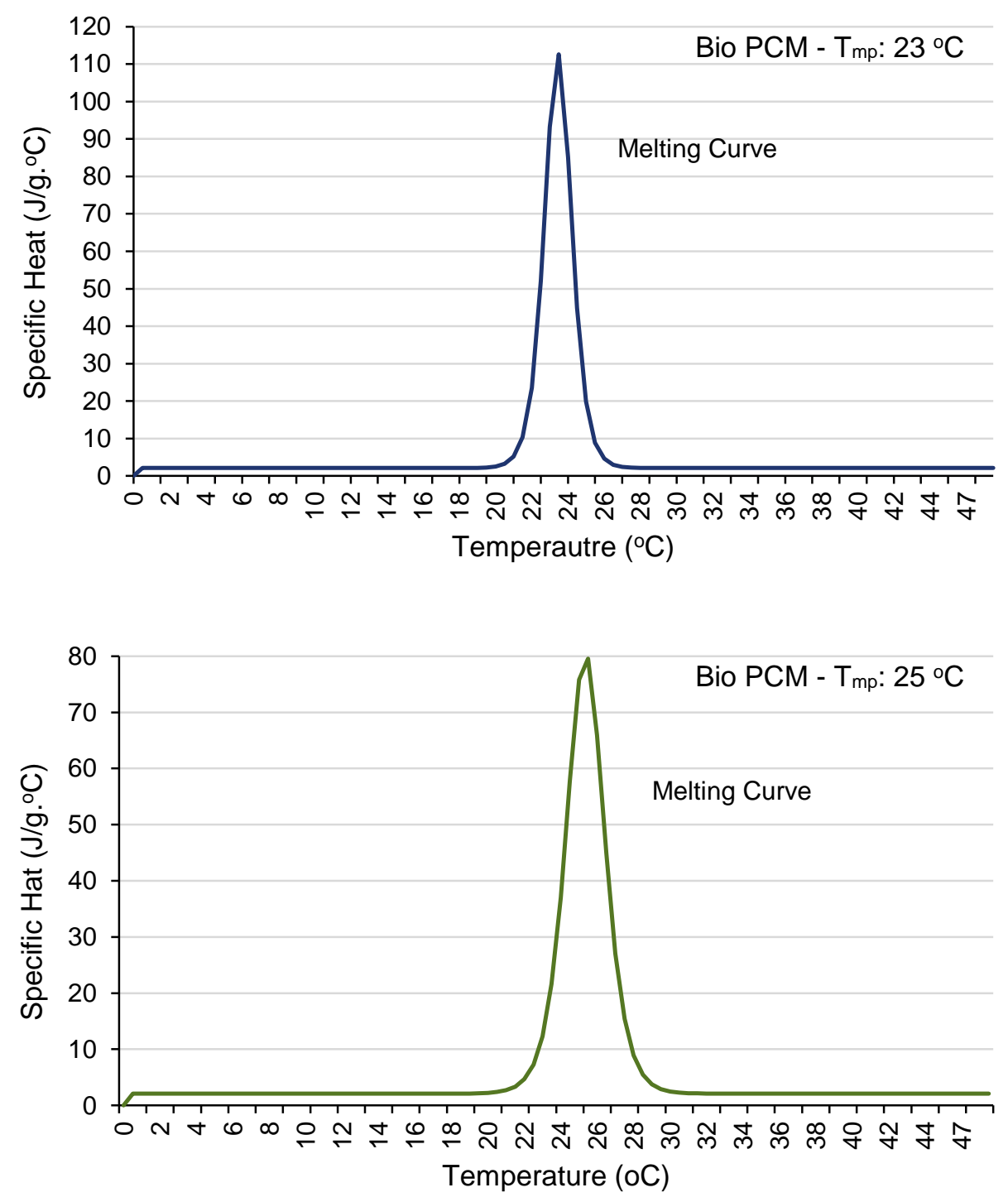

b) Specific heat of the two Bio PCM products (Phase Change Energy Solutions)

Figure 3.5. DSC graphs for Bio PCM and Energain products

Figure 3.5-b does not provide the hysteresis data for the Bio PCM product, however, in previous studies such as Muruganantham, (2010), a $4^{\circ} \mathrm{C}$ range for the Bio PCM product is calculated. For instance, considering a Bio PCM with the $\mathrm{T}_{\mathrm{mp}}$ of $25^{\circ} \mathrm{C}$ indicates an overall melting and freezing curve ranging from $21^{\circ} \mathrm{C}$ to $25^{\circ} \mathrm{C}$.

Melting points of 25 and $23^{\circ} \mathrm{C}$ for the Bio PCM product are both applicable to summer conditions in apartment units. However, an appropriate option based on climatic and indoor boundary conditions must be selected to form the composite PCM system with the Energain panel. Based on the review of previous studies Energy Plus has been shown as a reliable energy simulation program to quantify PCM performance. A preliminary study is first conducted for PCM optimization for the composite PCM system, correlating the thermophyscial properties 
of the selected PCM products to boundary conditions of Toronto and Vancouver units. After the configuration of the composite PCM system is finalized, the comprehensive investigation of PCM integration in apartment units is conducted to assess the impact of the proposed composite PCM system on energy consumption and thermal comfort. Detailed methodology and parameters of analysis for the simulation study in this research is outlined in section 4.1 .

In addition to simulation analysis that considers the performance of the composite PCM system on a building scale, it is necessary to monitor the individual PCM layers in order to understand their actual performance. The second part of this research is an experimental study conducted for four months in outdoor small scale test cells. The aim of this study is to monitor the daily behavior of the composite PCM layers, daily cycles, heat gain transfer to and from the layers as well as surface and room temperature profiles. An extensive overview of the experimental study's methodology is outlined in section 5.1.

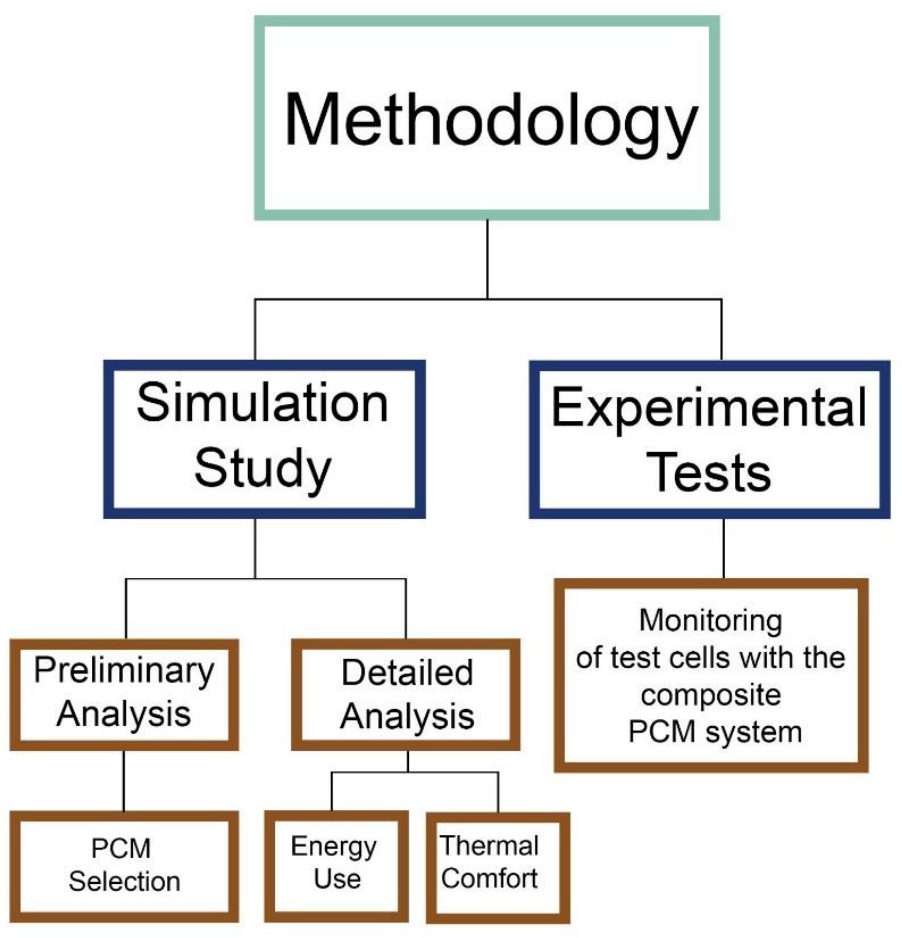

Figure 3.6. Research methodology diagram 


\section{Chapter 4 : Simulation Study}

For a holistic analysis of PCM performance on a building scale for a long testing period, the best method is to use whole building computer simulations. Computer modeling is an important tool in both the design stage of PCMs for decision making and the operation stage to characterize PCM's behavior parametrically. Furthermore, creating a simulation model allows for repeatability to test multiple variables such as climate, WWR, and orientation. For the simulation analysis, a typical apartment unit is modeled with variable parameters for each individual case study. Models have been created with Design Builder which uses Energy Plus as the simulation engine (Design Builder, 2016).

\subsection{Simulation study methodology}

This section reviews the model inputs, calculation algorithms as well as the performance indicators for the simulation study. Two apartment units are modeled, one base case unit as a benchmark with no PCM application and the second unit with PCM integrated surfaces. The main variable in the simulation study is window to wall ratio. Three WWRs of $40 \%, 60 \%$ and $80 \%$, representative of frequent WWRs in existing high-rise apartments in Toronto and Vancouver are selected. Thus, six separate units are created, one for each WWR scenario. Figure 4.1 displays a schematic view of the modeled units in Design Builder. As the figure shows, in this study middle apartment units with one window area have been tested.

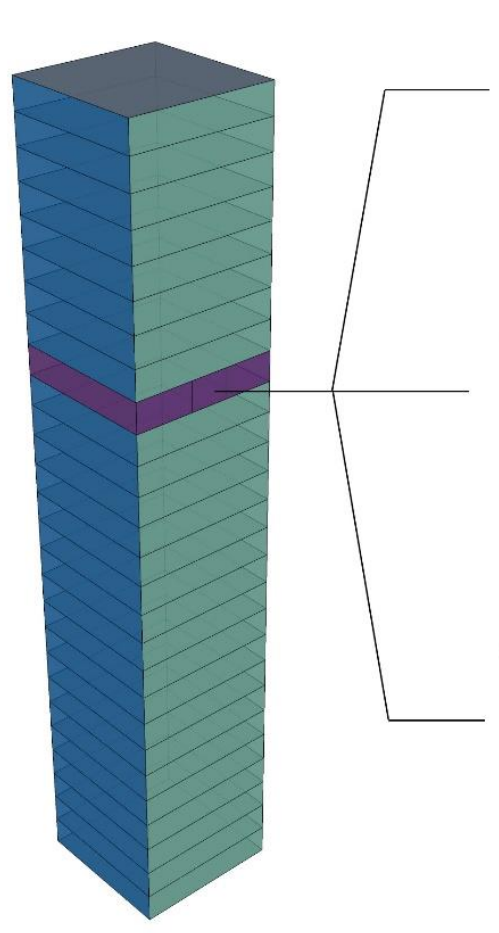

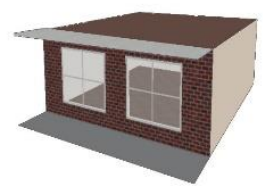

$40 \%$ WWR

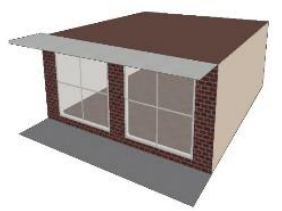

60\% WWR

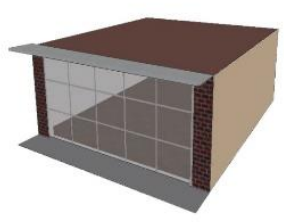

$80 \%$ WWR
Total Floor Area: $64 \mathrm{~m}^{2}$

Unit Dimensions:

$7.5 \times 8.5 \mathrm{~m}$

Unit Volume: $192 \mathrm{~m}^{3}$

Shading:

Cantilevered

balconies

Surface to

volume

ratio: 1.05

Figure 4.1. Three modeled units with different WWRs 
As stated by Binkley et al. (2012), WWR has a relation with the age of the building and the construction period. For instance, smaller WWRs suggest older buildings while buildings with $80 \%$ WWR are more recent such as constructions after 1990. Clearly, the construction characteristics in different time periods in high-rise apartments vary, however, to simplify the analysis and focus on the impact of PCMs, the construction of the modeled units is similar and does not consider different characteristics based on the age of construction. The modeled units are created considering conventional MURB construction characteristics. Complete construction properties of the base case unit are outlined in Table 4.1.

Typical structure of high-rise apartments in Toronto and Vancouver is reinforced concrete using flat slabs systems while the interior partition walls are constructed with steel studs and gypsum boards. The three main walls of the units are modeled with party walls comprised of steel studs with double gypsum boards on each side. No additional interior partitions are added in the modeled units. Incorporation of PCMs is investigated in the three main interior walls and the ceiling of the unit.

Table 4.1. Physical properties of the enclosure in the base case model

\begin{tabular}{|c|c|c|c|c|}
\hline $\begin{array}{c}\text { Construction } \\
\text { (Inside to outside) }\end{array}$ & $\begin{array}{l}\text { Thickness } \\
\text { (cm) }\end{array}$ & $\begin{array}{c}\text { Thermal } \\
\text { conductivity } \\
(\mathrm{W} / \mathrm{m} . \mathrm{K})\end{array}$ & $\begin{array}{l}\text { Specific Heat } \\
\left(\mathrm{KJ} / \mathrm{Kg} .{ }^{\circ} \mathrm{C}\right)\end{array}$ & $\begin{array}{l}\text { Density } \\
\left(\mathrm{Kg} \cdot \mathrm{m}^{3}\right)\end{array}$ \\
\hline \multicolumn{5}{|l|}{ Exterior Wall } \\
\hline $\begin{array}{l}\text { - Gypsum board } \\
\text { - Infill stud insulation } \\
\text { - Sheathing } \\
\text { - Brick }\end{array}$ & $\begin{array}{c}1.3 \\
11.4 \\
2 \\
10 \\
\end{array}$ & $\begin{array}{c}0.25 \\
0.035 \\
1 \\
0.84\end{array}$ & $\begin{array}{c}1 \\
1.5 \\
1 \\
0.8\end{array}$ & $\begin{array}{c}900 \\
10 \\
300 \\
1700 \\
\end{array}$ \\
\hline \multicolumn{5}{|l|}{ Interior Walls } \\
\hline $\begin{array}{l}\text { - Double gypsum boards } \\
\text { on steel studs }\end{array}$ & $2 \times 1.3$ & $\begin{array}{l}\text { No heat transfer in } \\
\text { the surface }\end{array}$ & 0.9 & 900 \\
\hline \multicolumn{5}{|l|}{ Ceiling } \\
\hline $\begin{array}{l}\text { - Gypsum tiles } \\
\text { - Concrete }\end{array}$ & $\begin{array}{l}1.3 \\
10\end{array}$ & $\begin{array}{c}\text { No heat transfer in } \\
\text { the surface }\end{array}$ & $\begin{array}{c}0.9 \\
1\end{array}$ & $\begin{array}{c}900 \\
1200\end{array}$ \\
\hline \multicolumn{5}{|l|}{ Floor } \\
\hline $\begin{array}{l}\text { - Ceramic tiles } \\
\text { - Concrete }\end{array}$ & $\begin{array}{c}1 \\
10 \\
\end{array}$ & $\begin{array}{c}\text { No heat transfer in } \\
\text { the surface }\end{array}$ & $\begin{array}{c}0.8 \\
1\end{array}$ & $\begin{array}{c}0.8 \\
1200\end{array}$ \\
\hline
\end{tabular}

A schematic section drawing of the enclosure assembly in the modeled unit is presented in Figure 4.2. For the interior layers, only half the thickness of the assembly is modeled. Heat transfer is only considered from the exterior wall and all other surfaces are set to adiabatic. The total resistance of the opaque exterior wall is $3.6 \mathrm{~m}^{2} . \mathrm{K} / \mathrm{W}$. The windows in the model are double glazing windows with an overall $\mathrm{U}$-value of $2.7 \mathrm{~W} / \mathrm{m}^{2} . \mathrm{K}$.

As mentioned in section 3.2, the year around composite PCM system consists of two layers- the Bio PCM and the Energain products as shown in Figure 4.3. This composite PCM system is integrated into the interior walls and ceiling of the modeled unit. This PCM application is a separate layer with $2 \mathrm{~cm}$ total thickness positioned behind the two gypsum boards as indicated in Figure 4.2. Bio PCM panel is the first layer behind the finishing drywall closer to the interior room environment and the Energain panel is located behind the Bio PCM. 


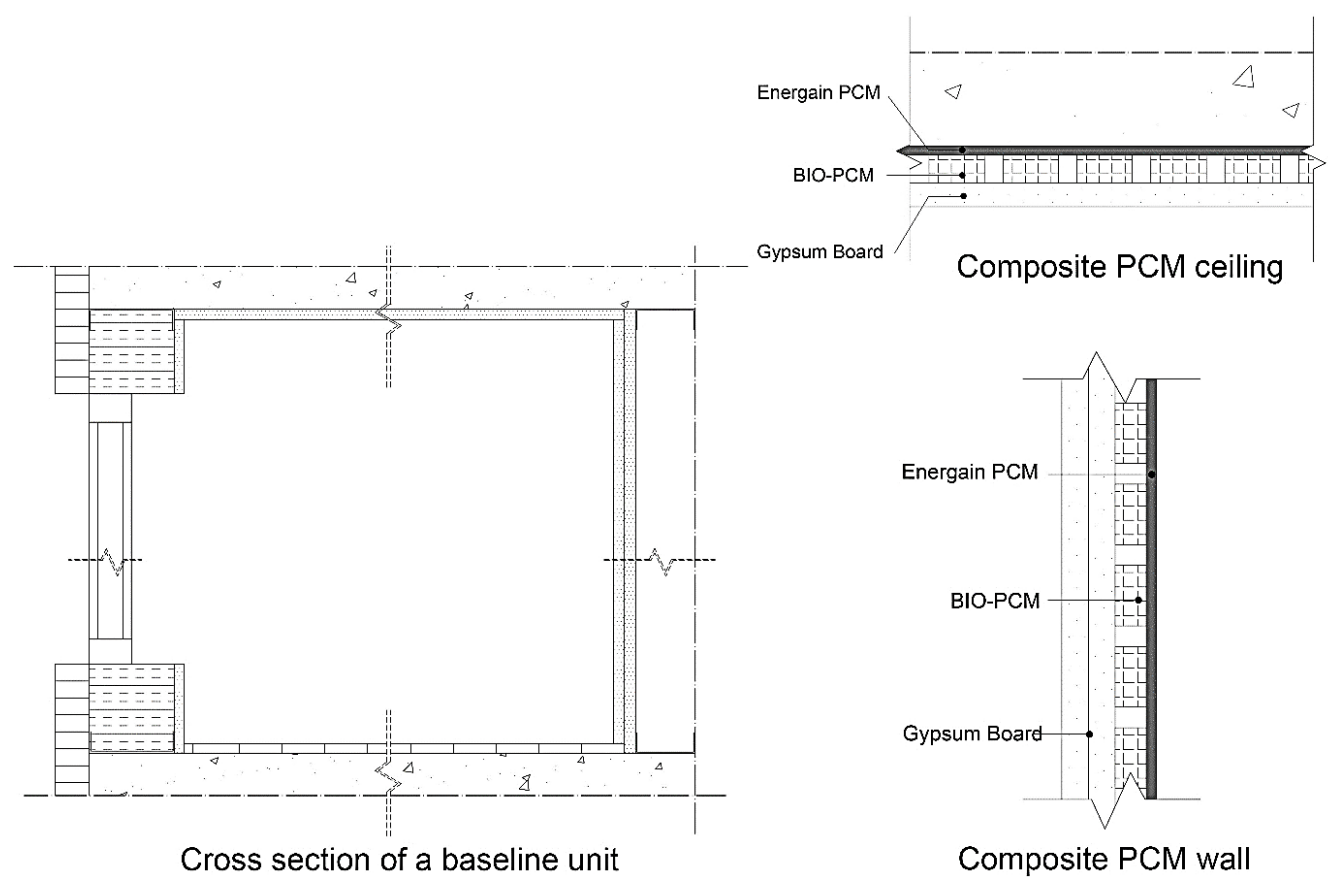

Figure 4.2. Section of the base case unit

The configuration of the composite PCM system is primarily based on the thermophysical properties of each PCM, specifically the heat conductivity. Both PCMs have low conductivity values, however, the conductivity of Energain is $0.18 \mathrm{~W} / \mathrm{m} . \mathrm{K}$ when solid and $0.14 \mathrm{~W} / \mathrm{m} . \mathrm{K}$ when liquid, while this value is $0.2 \mathrm{~W} / \mathrm{m} . \mathrm{K}$ for the Bio PCM panel. If Energain panel was positioned in the first layer it would melt faster than the Bio PCM in summer and result in slower heat transfer to the Bio PCM layer which is intended to regulate indoor summer temperatures.

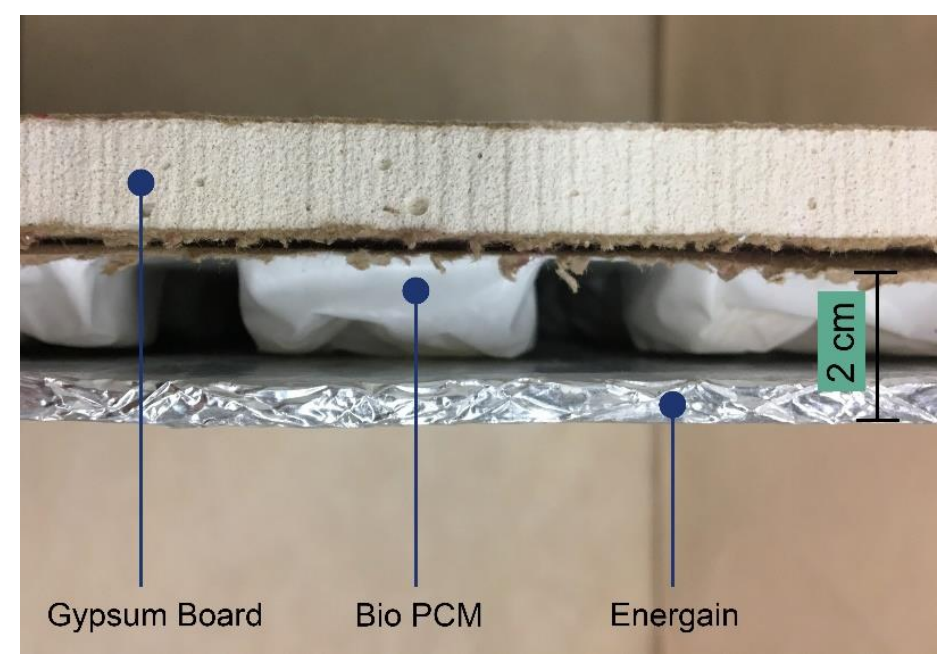

Figure 4.3. The composite PCM system 
This composite PCM system is applied to the entire surface of the interior walls and the ceiling. The amount of PCM applied to each surface in the simulated models is calculated in Table 4.2. Considering an area weight of $4.5 \mathrm{Kg} / \mathrm{m}^{2}$ for the Energain panel and $2.7 \mathrm{Kg} / \mathrm{m}^{2}$ for Bio PCM, the amount of PCM per number of panels that could be installed on a wall or the ceiling is calculated. One Energain panel weighs approximately $5.4 \mathrm{Kg}$, while one Bio PCM mat weighs about $1.3 \mathrm{Kg}$.

Table 4.2. PCM amount integrated into the interior surfaces

\begin{tabular}{|l|c|c|c|c|c|}
\hline \multirow{2}{*}{ Component } & \multirow{2}{*}{$\begin{array}{c}\text { Surface area } \\
\left(\mathbf{m}^{2}\right)\end{array}$} & \multicolumn{2}{|c|}{ Number of Panels } & \multicolumn{2}{c|}{ PCM weight $\left(\mathrm{Kg} / \mathbf{m}^{2}\right)$} \\
\cline { 3 - 6 } & & Bio PCM & Energain & Bio PCM & Energain \\
\hline $\begin{array}{c}\text { Window facing } \\
\text { wall }\end{array}$ & $7.5 \times 3=22.5$ & 42 & 14 & 2.4 & 3.3 \\
\hline One side wall & $8.5 \times 3=25.5$ & 49 & 16 & 2.5 & 3.4 \\
\hline Ceiling & $7.5 \times 8.5=63.7$ & 126 & 48 & 2.5 & 4 \\
\hline
\end{tabular}

\section{Design Conditions}

The simulation study is conducted for one full year to consider the entire range of different climatic conditions experienced in Toronto and Vancouver. Based on ASHRAE climate zone classification, Toronto is in zone 6 (Moderately wet-cold), while Vancouver is in zone 5 (wet, cool). The city of Toronto has very cold winters with hot summers, while Vancouver has a temperate climate with mild summers where in most parts of lower mainland in British Columbia no summer cooling is required. Toronto has 3687 heating degree days (HDD) and 347 cooling degree days (CDD), while HDD for Vancouver is 2712 and CDD is 62 (Government of Canada, 2016). Even though both cities are heating dominated, the cooling demands specifically in Toronto could be considerable. Each PCM layer is intended to get activated in either the cooling or heating season. However, it is important to observe their behavior in shoulder seasons too.

\section{Systems}

The mechanical system used in the model is a fan coil unit which is a typical system in high-rise apartments with both heating and cooling modes modeled. The heating system runs from Jan $1^{\text {st }}$ to May $20^{\text {th }}$ and again from September $20^{\text {th }}$ to December $31^{\text {st }}$. Cooling starts from May $20^{\text {th }}$ and operates until September $20^{\text {th }}$. In addition, to control the indoor comfort conditions, specific set points had to be defined for each season, the systems in this simulation model operate based on air temperature. Set points are the primary indicators of the indoor environment and should not be separate from PCMs' melting points to allow for a full phase change cycle.

The number of occupants considered in the modeled apartment unit is three. The occupancy schedule considers an unoccupied period from 9 am to $5 \mathrm{pm}$ each day with the highest activity in the early morning and evening. Occupancy schedule and the set points for heating and cooling are presented in Table 4.3. 
Table 4.3. Occupant profile and HVAC set points

\begin{tabular}{|l|c|c|c|}
\hline & Schedule & Heating set points & Cooling set point \\
\hline 0:00 - 7:00 AM & Main & $22^{\circ} \mathrm{C}$ & $24{ }^{\circ} \mathrm{C}$ \\
\hline 7:00 AM - 18:00 PM & Setback & $18{ }^{\circ} \mathrm{C}$ & $25^{\circ} \mathrm{C}$ \\
\hline 18:00 PM - 24:00 PM & Main & $22^{\circ} \mathrm{C}$ & $24^{\circ} \mathrm{C}$ \\
\hline
\end{tabular}

Indoor set points are selected to circulate above and below the composite PCM's functional melting temperature range to ensure activation cycles of the composite PCM system. This factor is investigated in detail in section 4.2.4.

A prominent method extensively studied in the literature is night cooling in summer to accelerate the solidification process of PCMs to be ready for the next cycle in the coming day. This night cooling is either facilitated by natural ventilation or mechanical ventilation. In the simulation model, natural ventilation is not considered, as including natural ventilation in high storey units is not generally available. Furthermore, natural ventilation is an occupant driven factor which is not a reliable method due to the unpredictable nature of occupant behavior. Thus, mechanical ventilation in the night is considered.

\section{PCM data inputs in Energy Plus:}

As discussed earlier in section 3.1.1, Energy Plus calculates PCM performance using the ConFD algorithm with an enthalpy method. The algorithm used is a fully implicit finite difference scheme with a temperature- enthalpy function. This function updates specific heat values at each time step iteration, as the specific heat of PCMs varies by the enthalpy which is a function of temperature. Details of this function in Energy Plus is explained and validated by Pedersen (2007); Tabares-Velasco et al. (2012a) and Shresta et al. (2011). A regular building material must first be created in Energy Plus, then phase change as a material property could be defined for the selected material.

The temperature-enthalpy function requires temperature inputs and corresponding enthalpies input in the model by the user. As enthalpy is updated at each time step it is used to develop a variable specific heat (Pedersen, 2007). In the case of a regular material, a constant $C_{P}$ could be used which is not accurate in PCM modeling as it might not consider the phase change process. The data inputs for the following equations in this study were supplied by DSC test results provided by manufacturers of both products. The enthalpy-temperature values were inserted into the model in a tabular form which is shown in Appendix I. Figure 4.4 shows the DSC curves of the products used in the simulation model.

As stated in the literature review, Energy Plus does not model PCM hysteresis, it allows for individual modeling using either the melting curve or the freezing enthalpy curve. The data inputs for the PCMs in this study are from the Gaussian curve and average of the melting and freezing cycles in the DSC. The calculation time-step in the software is set to one minute to ensure accurate assessment of the composite PCM layers. It is also suggested by Tabares et al. (2012a) that it using shorter time-steps when using the ConFD algorithm is more efficient 


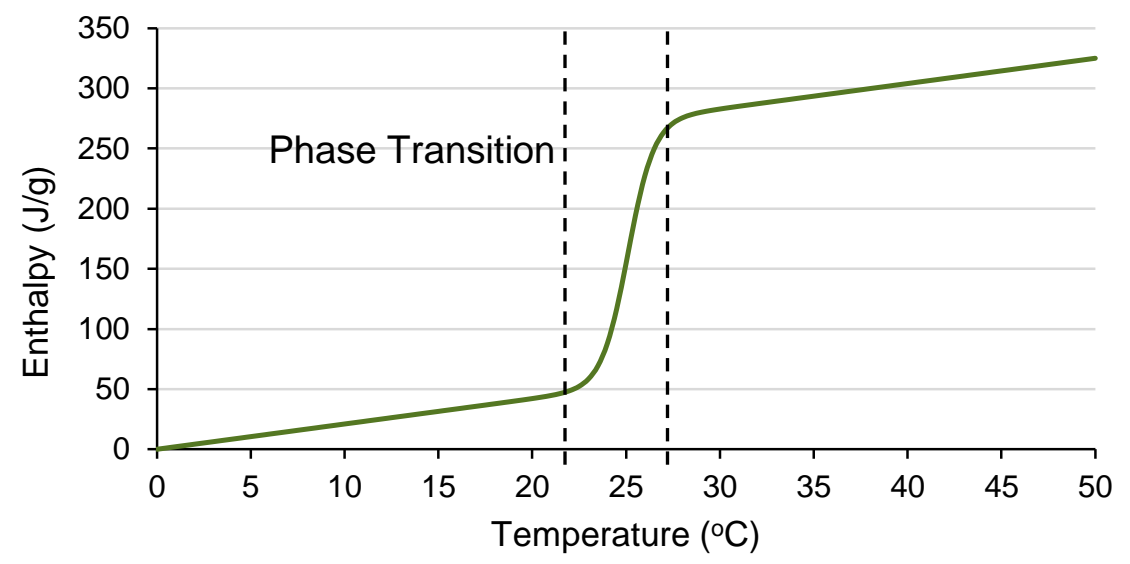

a) Bio PCM - $\mathrm{T}_{\mathrm{mp}}$ : $25^{\circ} \mathrm{C}-$ (Phase change energy solutions, 2016)

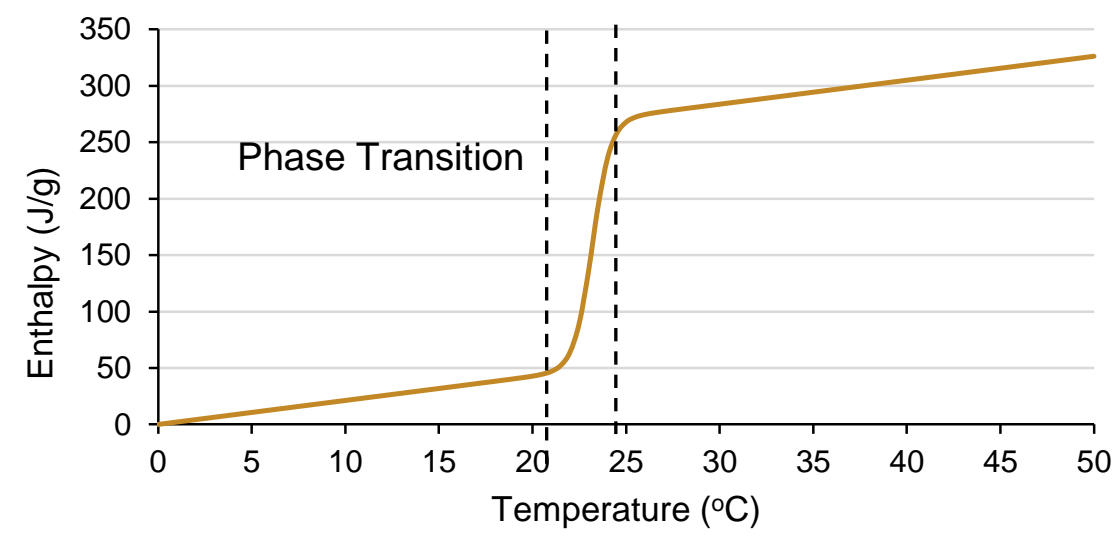

b) Bio PCM - $\mathrm{T}_{\mathrm{mp}}$ : $23^{\circ} \mathrm{C}$ - (Phase change energy solutions, 2016)

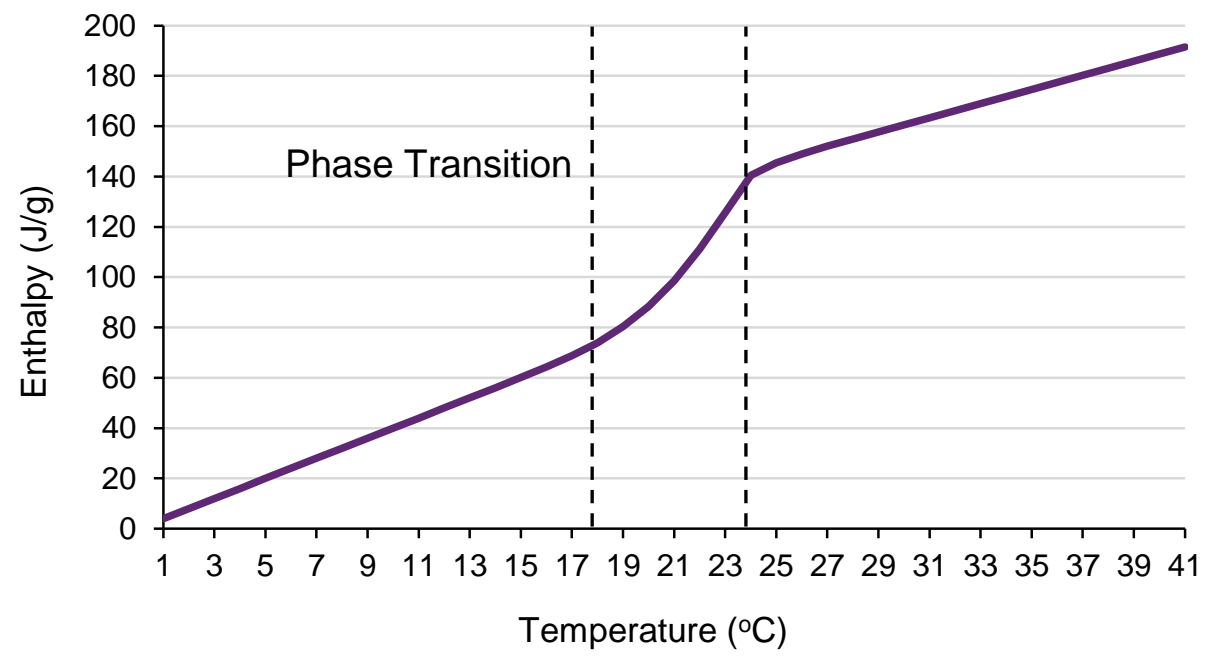

c) Energain $-T_{m p}: 21.7^{\circ} \mathrm{C}-$ (Obtained by product manufacturer)

Figure 4.4. Temperature-enthalpy curves 


\subsubsection{Parameters of analysis}

The simulation study is characterized by two main sections, the preliminary analysis to select the appropriate melting point for the Bio PCM layer and the main simulation study to assess the impact of the composite PCM system on a whole building scale. The simulation study is a comparative analysis focused on the rate of changes in indoor temperatures and energy consumption caused by the application of PCM. For ease of comparison, the unit with no PCM is referred to as the "Baseline unit" and the unit with PCM-enhanced walls and ceiling is called the "PCM integrated unit".

The governing variables in the simulation study are glazing ratio and climate. Variable glazing ratios are selected to draw a line between the composite PCM's melting points and solar gain in the units. Two different climates are selected to investigated the impact of climate on the composite PCM's performance. Other variables tested are listed in Table 4.4 which have been analyzed in detail in separate tests. Each of the following tests has been studied individually for the Toronto and Vancouver case, furthermore, all the tests except for the preliminary analysis have been conducted for one full year to test the seasonal performance of PCMs. The seasonal and climate variables are present in all the studies, while other variables are switched between each test from being constant to being the main variable of that test.

Table 4.4. Simulation tests parameters of study

\begin{tabular}{|c|c|c|c|}
\hline Test & Tested variables & Constant variables & Description \\
\hline $\begin{array}{l}\text { Preliminary } \\
\text { Simulation }\end{array}$ & $\begin{array}{l}\text { 1- Melting temperature of Bio PCM } \\
\text { 2-WWR: } \\
40 \%, 60 \%, 80 \%\end{array}$ & $\begin{array}{l}\text { Orientation } \\
\text { Set points }\end{array}$ & $\begin{array}{l}\text { Test was conducted in summer to } \\
\text { select the } \\
\text { most appropriate Bio PCM melting } \\
\text { point }\end{array}$ \\
\hline Study \#1 & WWR: $40 \%, 60 \%, 80 \%$ & $\begin{array}{l}\text { Orientation } \\
\text { Set points }\end{array}$ & $\begin{array}{l}\text { - The different WWRs are tested in } \\
\text { south facing units to correlate WWR } \\
\text { and PCM effectiveness. }\end{array}$ \\
\hline Study \#2 & Unit Orientation & $\begin{array}{l}\text { WWR } \\
\text { Set points }\end{array}$ & $\begin{array}{l}\text { - Units facing four cardinal } \\
\text { directions are tested in one WWR } \\
\text { case to check the performance of } \\
\text { PCMs }\end{array}$ \\
\hline Study \#3 & $\begin{array}{l}\text { Heating and Cooling set point } \\
\text { Temperatures: } \\
\text { Ranging from } 20-26{ }^{\circ} \mathrm{C} \\
\end{array}$ & $\begin{array}{c}\text { WWR } \\
\text { Orientation }\end{array}$ & $\begin{array}{l}\text { - Different ranges for Heating and } \\
\text { cooling set points are tested }\end{array}$ \\
\hline Study \#4 & Amount of PCM & $\begin{array}{c}\text { Set points } \\
\text { Orientation } \\
\text { WWR }\end{array}$ & $\begin{array}{l}\text { - The amount of PCMs are tested } \\
\text { by addition to internal partitions. } \\
\text { - Assessing the impact of PCM area } \\
\text { on latent heat capacity }\end{array}$ \\
\hline
\end{tabular}

\section{Parameters of analysis:}

The following parameters are the key performance indicators for PCM performance analysis that have been quantified in all four simulation studies. In addition to thermal comfort and energy consumption parameters, a third performance indicator is investigated, designated as the PCM performance factor. 
Indoor thermal environment:

The impact of PCMs on the thermal environment is investigated by observing the changes in indoor operative and radiant temperatures. Parameters of analysis are:

- Number of hours within ASHRAE 55 (2013) comfort range;

- Daily temperature Fluctuations;

- Operative temperature changes;

- Radiant temperature changes;

- High and low peak temperatures

\section{* Energy consumption:}

The pattern of energy use is analyzed with regards to thermal energy storage cycles of the composite PCM system. As stated in the existing literature, the highest effect of PCMs on energy use is on peak energy thus peak energy consumption is an important parameter to be investigated. Parameters of analysis are:

- Total Heating/Cooling energy consumption;

- Percentage of energy savings;

- Peak Heating/Cooling energy loads;

- Daily Peak shifting

\section{* PCM performance:}

This factor is intended to analyze the behavior of PCMs during the day and the sensibility of the composite PCM system to tested variables in each section. This section is important to find the most important factors affecting PCMs behavior and daily cycles. Parameters of analysis are:

- Number of daily PCM Cycles;

- Surface temperature variations;

- Frequency of PCM activation, (first introduced by Evola et al., 2013)

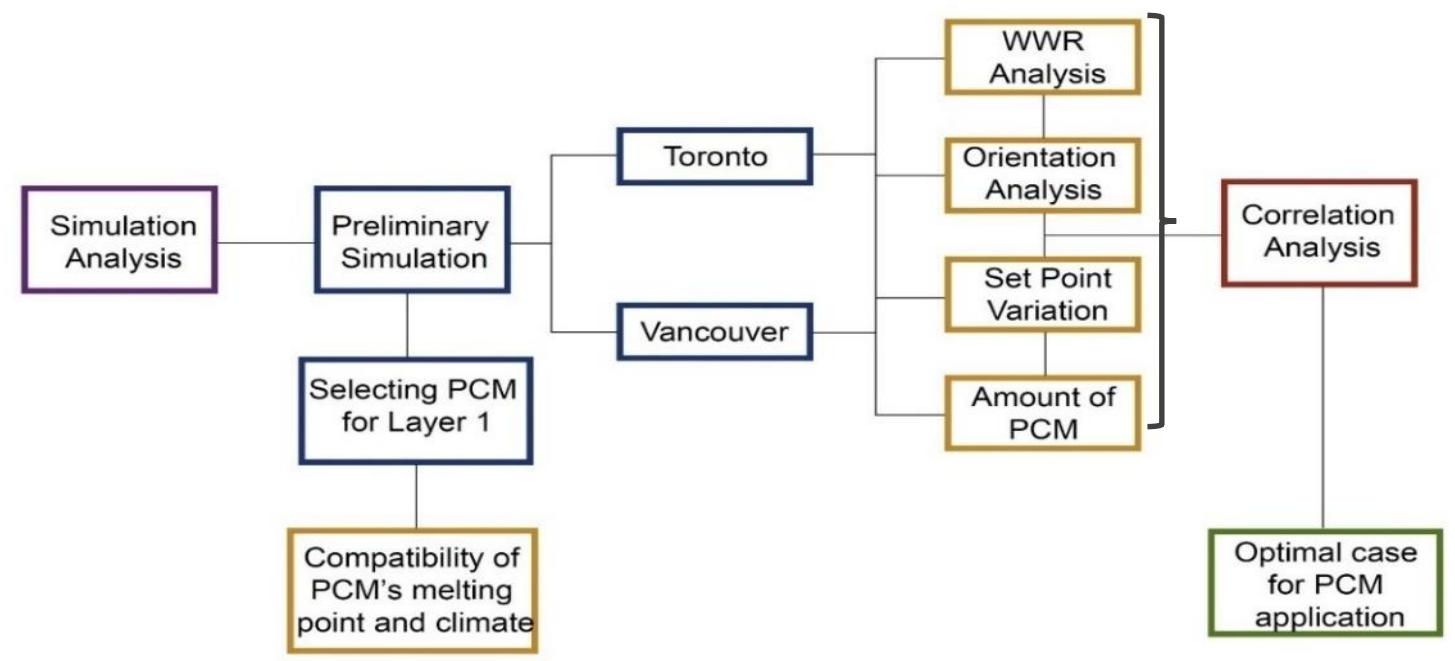

Figure 4.5. Simulation study diagram 


\subsection{Results}

A total of 522 simulation runs are performed to investigate the effect of the proposed composite PCM system in high-rise apartment units. The whole building simulations allow for a broad assessment of PCMs in this typology of buildings which could further be used in future research. The first section outlined here is the design stage of the composite PCM system in the preliminary analysis. The following sections show results of an annual simulation to assess the impact of the composite PCM system in more detail in each season. The total annual energy use intensity obtained from the simulations in both cities of Toronto and Vancouver were in the range of values from reviewed literature on high-rise apartments in these two cities.

\subsubsection{Preliminary simulations}

The preliminary simulation is conducted to provide an initial approximation of how the Bio PCM layer would regulate indoor temperatures in summer and impact the cooling energy. The preliminary study is conducted for three months of June, July and August. Total cooling energy use and peak cooling are investigated in addition to thermal comfort considering changes in daily temperature swings.

A correlation study between the two melting points of $23^{\circ} \mathrm{C}$ and $25^{\circ} \mathrm{C}$ for the Bio PCM is presented. The simulation results for the city of Toronto shown in Figure 4.6 demonstrate a better overall performance of Bio PCM with the melting point of $25^{\circ} \mathrm{C}$ in reducing overall cooling energy use in each summer month. In the same figure, the percentage of reduction in average daily indoor operative temperature swings is also displayed, which shows a significantly better performance of the Bio PCM with the melting point of $25^{\circ} \mathrm{C}$.

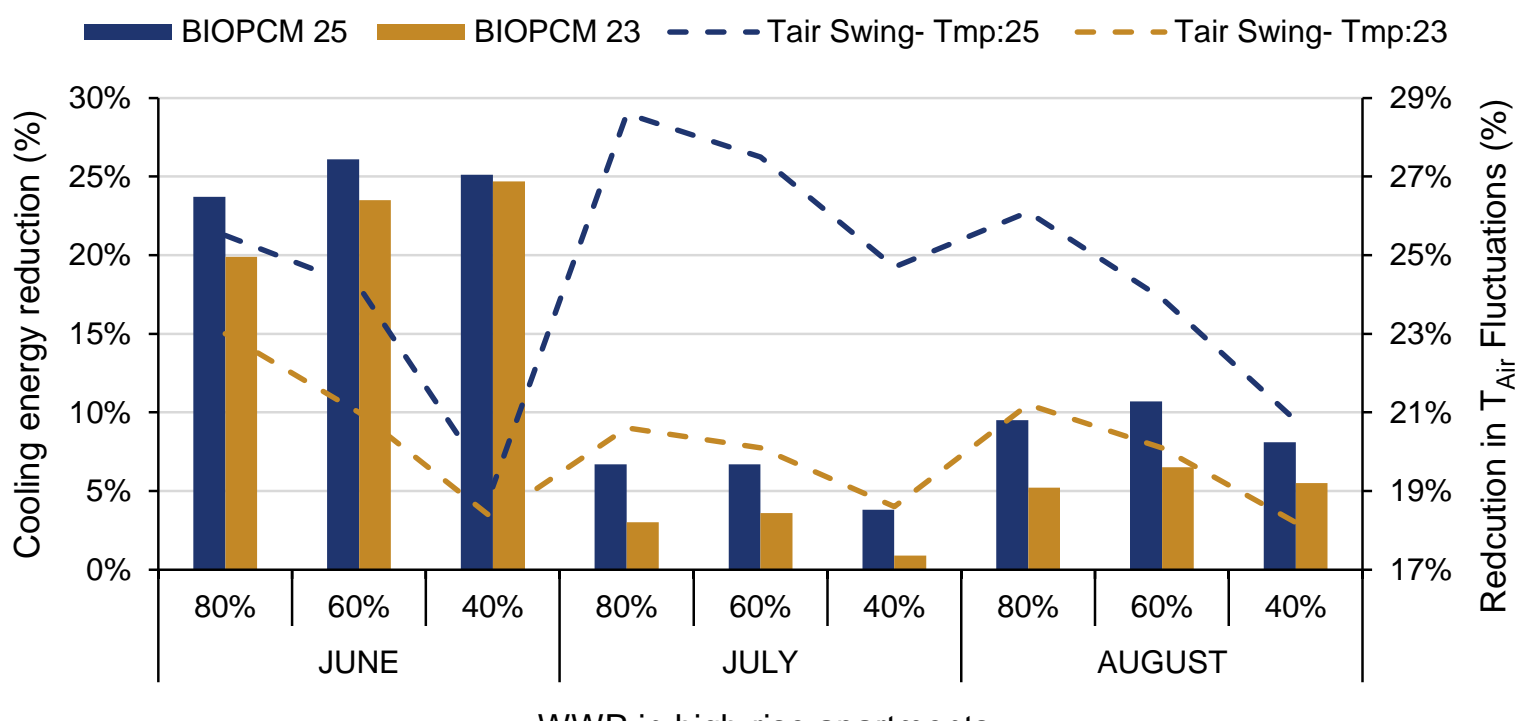

Figure 4.6. Correlation of cooling energy use and air temperature swing changes- Toronto

In addition to daily temperature fluctuations, the effect of the two Bio PCM products was assessed by comparing the reduction in temperatures above $26^{\circ} \mathrm{C}$ and below $21^{\circ} \mathrm{C}$ which are the thresholds for thermal discomfort. In the city of Toronto, hours in which temperatures exceed $26{ }^{\circ} \mathrm{C}$ are mostly in the month of July and August. Higher instances of operative temperatures 
exceeding above $26^{\circ} \mathrm{C}$ are observed in the $80 \%$ baseline unit with an overall 74 hours in the month of July. By applying Bio PCM-25 and Bio PCM-23, a substantial decrease in the number of hours with temperatures higher than $26{ }^{\circ} \mathrm{C}$ is shown. However, by incorporating Bio PCM-25, 56 hours in July show temperatures above $26^{\circ} \mathrm{C}$, which is 18 hours lower than the baseline unit. The same comparison using Bio PCM-23 shows a 13-hour decrease in the month of July.

Similar results are observed for peak temperature reductions in the month of August showing a better performance of Bio PCM-25 in reducing high peak temperatures above $26^{\circ} \mathrm{C}$.

Conversely, in the month of June in all WWRs in Toronto, the number of hours in which indoor air temperature falls below $21^{\circ} \mathrm{C}$ is higher. The impact of both PCM products in keeping temperatures above $21^{\circ} \mathrm{C}$ is quite similar. However, comparing the effectiveness of the Bio PCM product in reducing overheating and increase in low peak temperatures, a significantly better performance could be observed in reducing low peak temperatures. For instance, in the $60 \%$ WWR unit in the month of June, total hours in which indoor air temperatures fall below 21 ${ }^{\circ} \mathrm{C}$ are 135 hours, however by applying Bio PCM -25 this number drops to only 30 hours. When Bio PCM-23 is used, 39 hours in June are observed with temperatures below $21^{\circ} \mathrm{C}$.

Figure 4.7 shows the correlation analysis for two melting points in the city of Vancouver. The percentage of reduction in cooling energy use by using PCM products is significantly higher in the city of Vancouver compared to the city of Toronto with an average cooling energy reduction of $50 \%$. In contrast to Toronto, the performance of Bio PCM-25 is not always higher in reducing cooling energy use, as Fig. 4.7 shows, Bio PCM-23 performs better in Vancouver units in regulating temperature swings and reducing energy consumption in the month of June with $100 \%$ energy saving in $40 \%$ WWR units.

Due to milder weather conditions in the city of Vancouver, the number of hours in which indoor air temperatures exceed above $26^{\circ} \mathrm{C}$ is not high during the summer, in fact in units with $40 \%$ WWR, during the entire summer, temperatures are always below $26^{\circ} \mathrm{C}$ in the baseline unit and the PCM integrated units. However, a better performance of PCMs is observed in reducing high peak temperatures, specifically in the month of August in $60 \%$ and $80 \%$ WWR units.

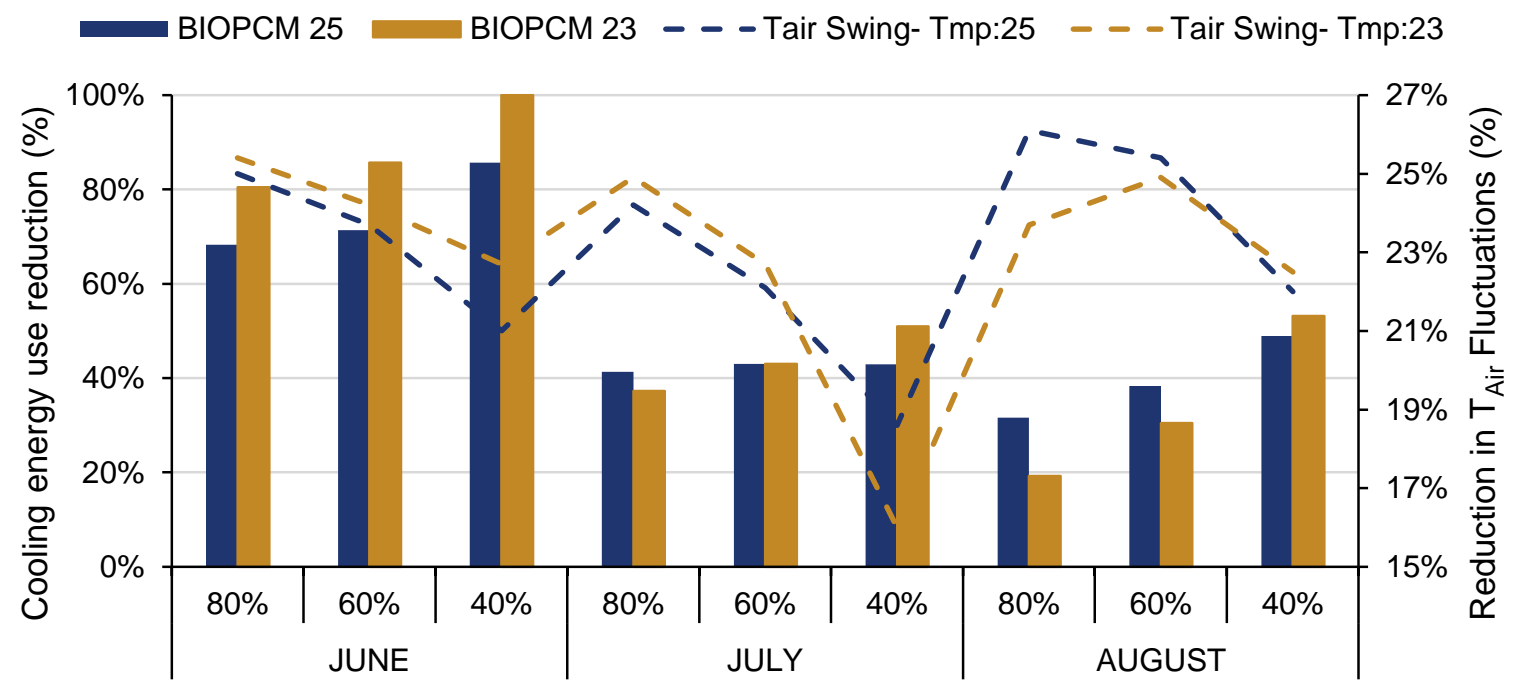

WWR in high-rise apartments

Figure 4.7. Correlation of cooling energy use and air temperature swing changes- Vancouver 
The trend of change for both Vancouver and Toronto shown in figures 4.6 and 4.7 demonstrate a higher effectiveness of Bio PCM with the melting point of $23^{\circ} \mathrm{C}$ in units with $40 \%$ WWR and in all units in the month of June. Since in June the indoor temperatures are closer to $23^{\circ} \mathrm{C}$, the effectiveness of Bio PCM-23 is higher in reducing energy use and indoor temperature swings. However, in an annual simulation run, Bio PCM-25 has a higher energy use reduction compared to Bio PCM-23 indicating a better performance in shoulder seasons. A comprehensive investigation of indoor air compatibility and PCM performance will be discussed in section 4.2.4. A final investigation on the two melting points is performed by comparing the total annual cooling energy use intensity in both cities of Vancouver and Toronto in Fig. 4.8.
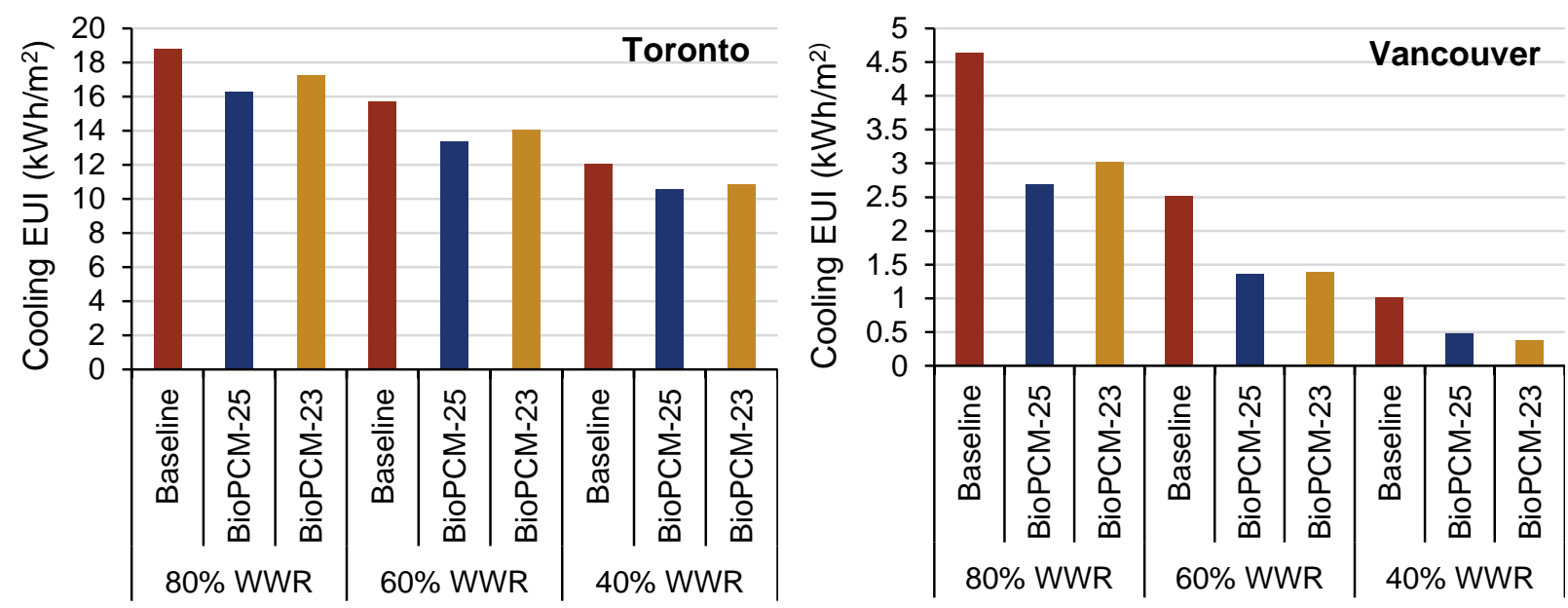

Figure 4.8. Cooling Energy use intensity in summer

Substantial reduction in total cooling energy use, in addition to decrease in overheating in summer in both cities by using Bio PCM with a higher melting temperature, prompted to the selection of Bio PCM with the melting point of $25^{\circ} \mathrm{C}$ for layer one of the composite PCM system. Therefore, the final composite PCM configuration consists of Bio PCM with melting temperature of $25^{\circ} \mathrm{C}$ in layer 1 and Energain PCM with melting temperature of $21.7^{\circ} \mathrm{C}$ in layer 2.

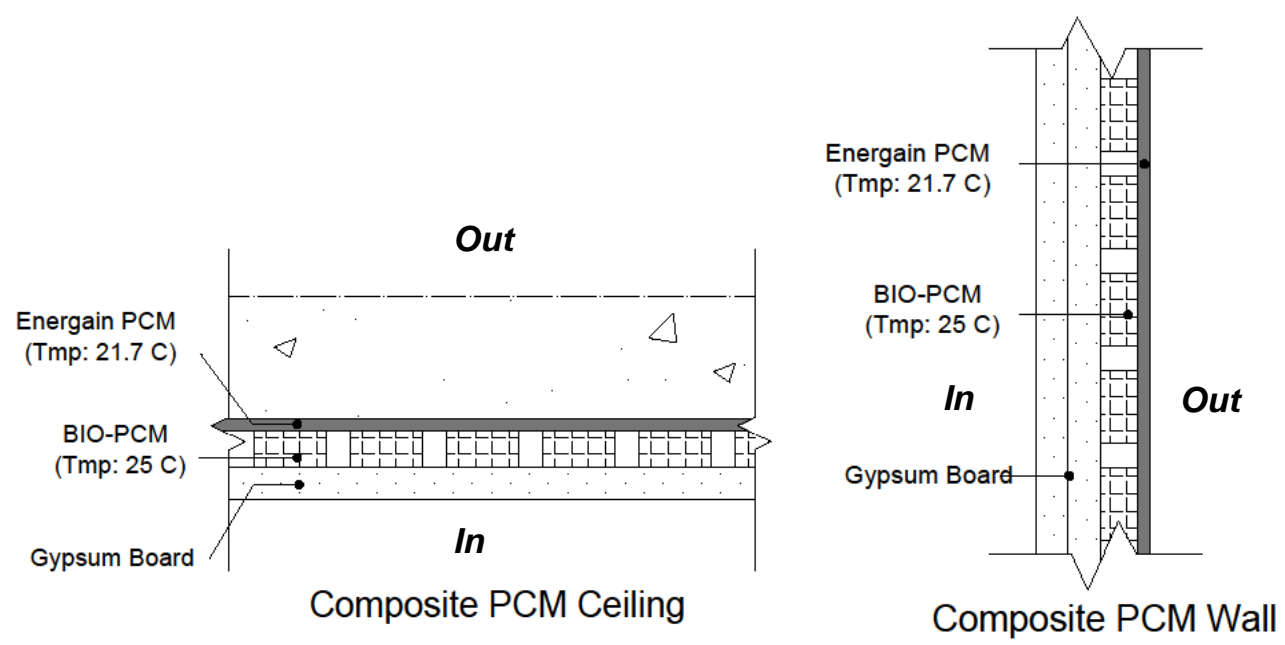

Figure 4.9. Final composite PCM configuration 


\subsubsection{Study \#1: Effect of WWR on PCM performance}

This simulation study aims at drawing a correlation between the three WWRs in apartment units and effectiveness of PCMs in regulating indoor temperatures and improving energy efficiency. While three different WWRs are tested in this study, the orientation of the units is kept to the south. The outcomes of this study are assessed first on an annual basis comparing the baseline unit and the PCM integrated unit to find the rate of change caused by the composite PCM system in Vancouver and Toronto. A detailed investigation is further carried out in months of April, July, October and February to assess the effect of seasonal temperature variations on PCM performance.

To calculate the rate of change in energy consumption, namely energy savings by the PCM system in the PCM integrated units, the following calculation is performed:

Cooling / heating energy saving:

$\Delta E_{\text {Saving }}=\left[\left(E_{\text {Baseline Unit }}-E_{P C M \text { integrated unit }}\right) / E_{\text {Baseline Unit }}\right] \times 100$

\section{Peak load savings:}

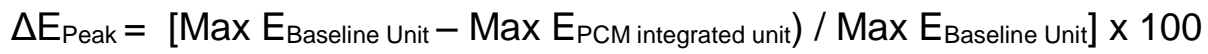

As shown in Table 4.5, the impact of the composite PCM system is considerably higher in reducing the cooling energy use intensity in apartment units in both Toronto and Vancouver. Comparing the rate of change in total energy loads, significantly higher savings could occur by implementing the composite PCM system in apartment units in Vancouver. It should be noted that overall heating and cooling energy loads in baseline units are also lower in Vancouver due to milder weather conditions. A total reduction of $4.4 \%$ in annual energy use intensity could be achieved in apartment units with $80 \%$ WWR in Vancouver, whereas in the same units in Toronto the reduction in annual EUI is $2.6 \%$.

Table 4.5. Annual energy loads

\begin{tabular}{|c|c|c|c|c|c|c|}
\hline & \multicolumn{3}{|c|}{ Cooling loads $\left(\mathrm{kWh} / \mathrm{m}^{2}\right)$} & \multicolumn{3}{|c|}{ Heating loads $\left(\mathrm{kWh} / \mathrm{m}^{2}\right)$} \\
\hline Toronto & $\begin{array}{c}\text { Baseline } \\
\text { unit }\end{array}$ & $\begin{array}{c}\text { PCM } \\
\text { integrated } \\
\text { unit }\end{array}$ & $\begin{array}{c}\Delta E_{\text {Saving }} \\
(\%)\end{array}$ & $\begin{array}{c}\text { Baseline } \\
\text { unit }\end{array}$ & $\begin{array}{c}\text { PCM } \\
\text { integrated } \\
\text { unit }\end{array}$ & $\begin{array}{c}\Delta E_{\text {Saving }} \\
(\%)\end{array}$ \\
\hline $\begin{array}{l}\text { Toronto- } \\
80 \% \text { WWR }\end{array}$ & 21.2 & 18.1 & $14.7 \%$ & 112.7 & 111.5 & $1.1 \%$ \\
\hline $\begin{array}{l}\text { Toronto- } \\
60 \% \text { WWR }\end{array}$ & 17.26 & 14.5 & $16 \%$ & 107.8 & 107.3 & $0.5 \%$ \\
\hline $\begin{array}{l}\text { Toronto- } \\
40 \% \text { WWR }\end{array}$ & 13.1 & 11.2 & $14.3 \%$ & 105.4 & 105.6 & $-0.2 \%$ \\
\hline $\begin{array}{l}\text { Vancouver- } \\
80 \% \text { WWR }\end{array}$ & 6.4 & 3. & $38.1 \%$ & 71.6 & 68.9 & $3.7 \%$ \\
\hline $\begin{array}{l}\text { Vancouver- } \\
60 \% \text { WWR }\end{array}$ & 3.4 & 1.8 & $46.8 \%$ & 67.5 & 66.2 & $2 \%$ \\
\hline $\begin{array}{l}\text { Vancouver- } \\
40 \% \text { WWR } \\
\end{array}$ & 1.2 & 0.5 & $56.1 \%$ & 65.9 & 65.7 & $0.3 \%$ \\
\hline
\end{tabular}


Percentage of load reduction is highest in June in the cooling season in all WWR scenarios in Vancouver and Toronto, which is four times the amount of load saving in July. In fact, in Vancouver units, average cooling load reduction in June is $75 \%$ in all three WWRs. In the heating season in Toronto units, highest percentage of saving is observed in October with an average $10 \%$ heating load reduction, while in Vancouver units, highest reduction of monthly heating loads is observed in September.

The potential for the composite PCM system in drastically decreasing cooling loads is high, while its effectiveness in the heating season is not notable specifically in units with lower WWRs. However, similar to total energy use reduction, Vancouver units experience a higher rate of reduction in annual heating loads. Since the highest savings are obtained in cooling energy, monthly average cooling energy use in Toronto and Vancouver units is presented in Figure 4.10. The maximum energy loads in the cooling season occur in the month of August in Vancouver, and in July in Toronto units.
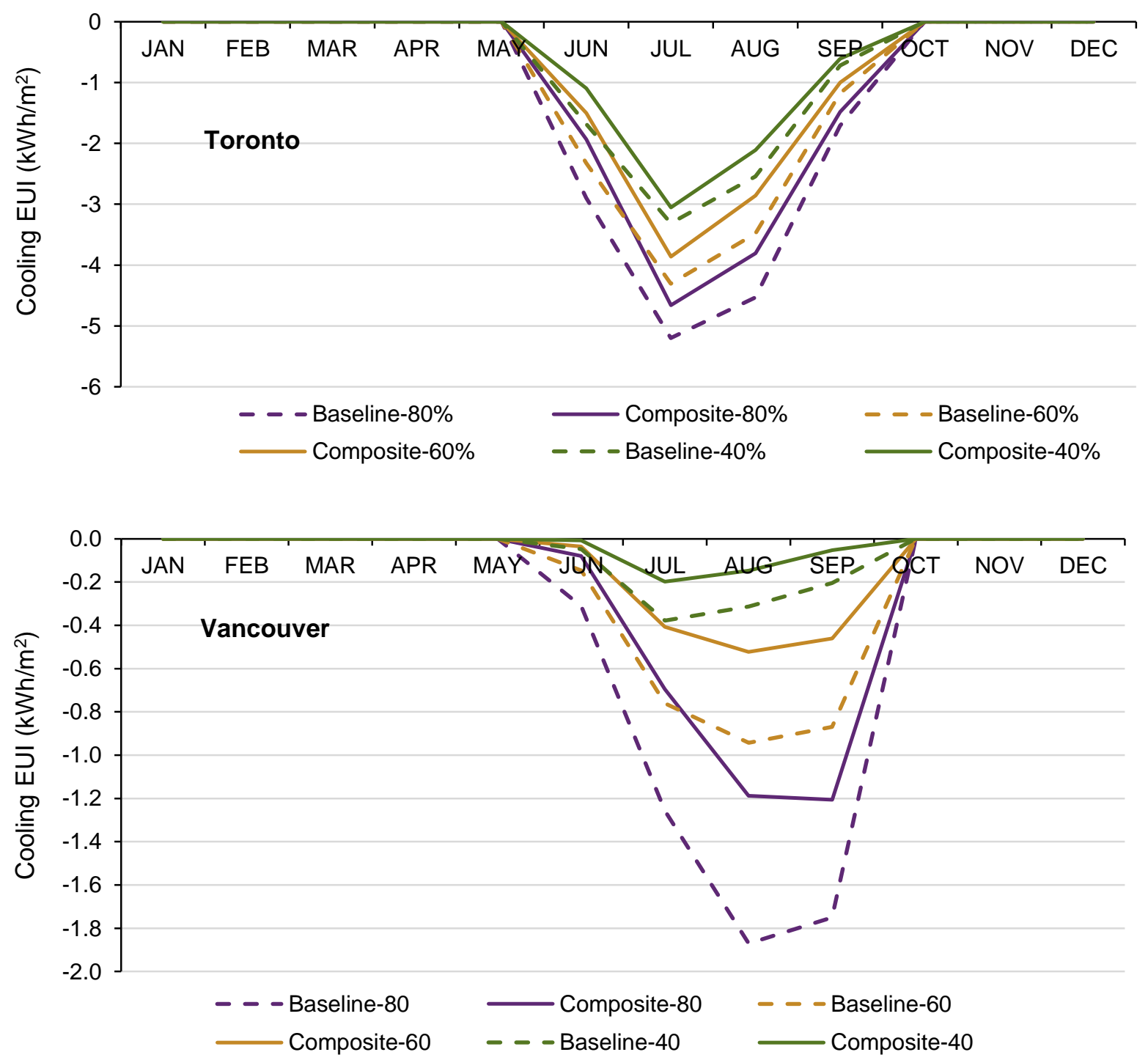

Figure 4.10. Monthly cooling energy loads 
By analyzing the graphs in Fig. 4.10 in more detail, a similar pattern of energy use is observed in both baseline unit and PCM integrated unit in the city of Toronto. Substantial reduction of $9 \%$ in each different WWR scenario could be seen with the highest reduction in energy loads from June to August. However, in the last week of May and first two weeks of September, the impact of PCM in reducing cooling load is minimal.

A sharp contrast could be seen in the case of Vancouver units as the energy consumption pattern in the PCM integrated unit is considerably different from the pattern of energy use in the baseline unit in all WWR scenarios. Significant reduction of cooling loads in the last weeks of May in the PCM integrated unit is shown. Cooling is almost eliminated in the month May by using the composite PCM system in $60 \%$ and $40 \%$ WWR units.

In addition to energy use, thermal environmental changes are assessed. Thermal discomfort hours based on ASHRAE standards is defined as the number of hours in which indoor operative temperatures are not within the required temperatures considered comfortable by ASHRAE 55 (2013) guideline. Figure 4.11 shows the rate of change in monthly thermal discomfort hours in each WWR scenario in Toronto and Vancouver units. The impact of the composite PCM system in reducing thermal discomfort hours is mainly negative in July and August, while the highest improvement in thermal comfort is achieved in the fall season and the month of June.
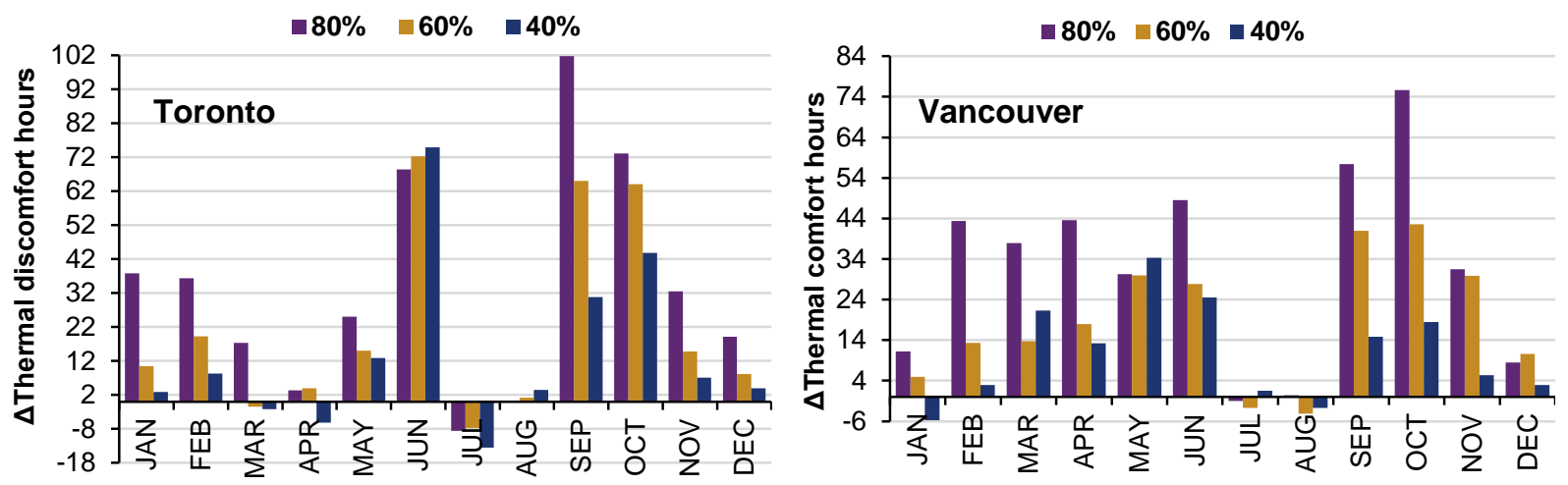

Figure 4.11. Variation in monthly thermal discomfort hours

As presented in the previous figures, the effectiveness of PCM integration is significantly higher in units with $80 \%$ WWR in both cities. For instance, in Toronto units by integrating the composite PCM system to $80 \%$ WWR units, total thermal comfort hours are increased by 102 hours. Similarly, the highest increase in thermal comfort hours occurs in October in $80 \%$ WWR Vancouver unit which experiences 75 hours additional comfort hours. Considering annual thermal comfort, Toronto units on average experience a better thermal comfort improvement.

A more detailed energy analysis was performed in April, July, October, and February to better illustrate daily energy load changes specifically peak energy load variations. First, considering Toronto units, a better energy performance is observed in the month of October in the PCM integrated units. Average hourly energy loads in each day of the studied months show a maximum of $100 \%$ peak load energy saving in multiple days in the month of October in $80 \%$ and $60 \%$ WWR units, indicating passive cooling in the PCM integrated units for those periods. Similarly, overall monthly energy saving is also higher in the month of October for all WWR scenarios compared to other months. 
In contrast to Toronto units, in Vancouver, highest monthly energy use and peak load savings are observed in July with a total energy saving of $43 \%$ in cooling energy in the PCM integrated units with $40 \%$ and $60 \%$ WWR. The pattern of change in peak load reduction corresponds with monthly energy use reduction as the highest peak energy load reduction in $40 \%$ and $60 \%$ WWR is also observed in July, while highest peak heating load reduction is in $80 \%$ WWR in October. Even though there is a minimal heating saving in the month of February, the overall rate of change in the PCM integrated units in Vancouver in this month is more significant than in Toronto. For instance, by referring to Fig. 4.11, a 5.2\% monthly energy saving and nearly $30 \%$ decreased peak heating load is presented in February in Vancouver units. In the same month in $80 \%$ WWR Toronto units, total energy saving is negative indicating a rise in energy use when PCMs are applied to surfaces, in addition, peak heating loads are changed by only $8.8 \%$.

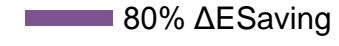

- - $-80 \% \Delta$ EPeak

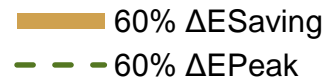

- $-60 \% \Delta$ EPeak

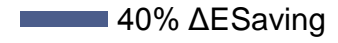

- - $-40 \% \Delta$ EPeak
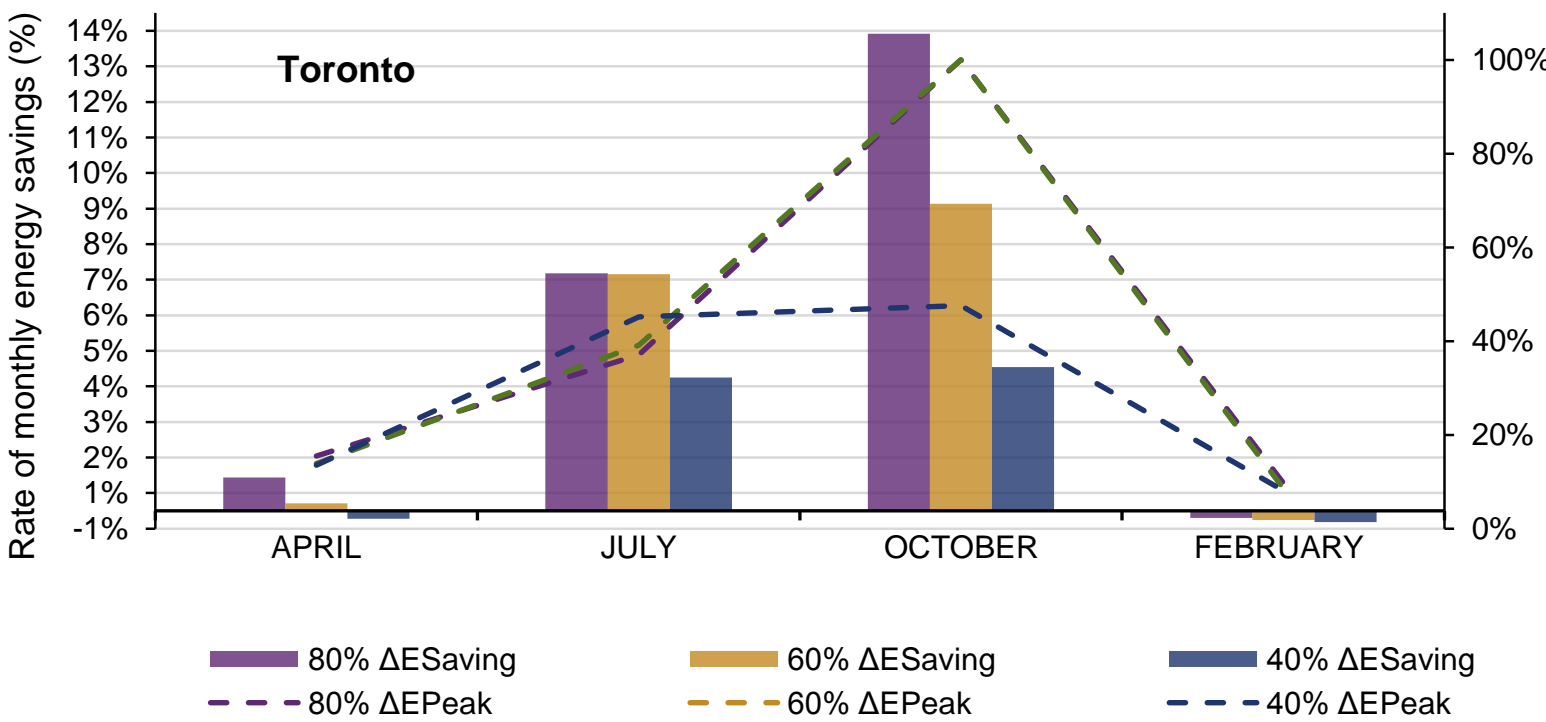

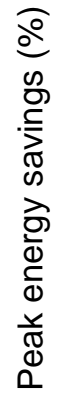

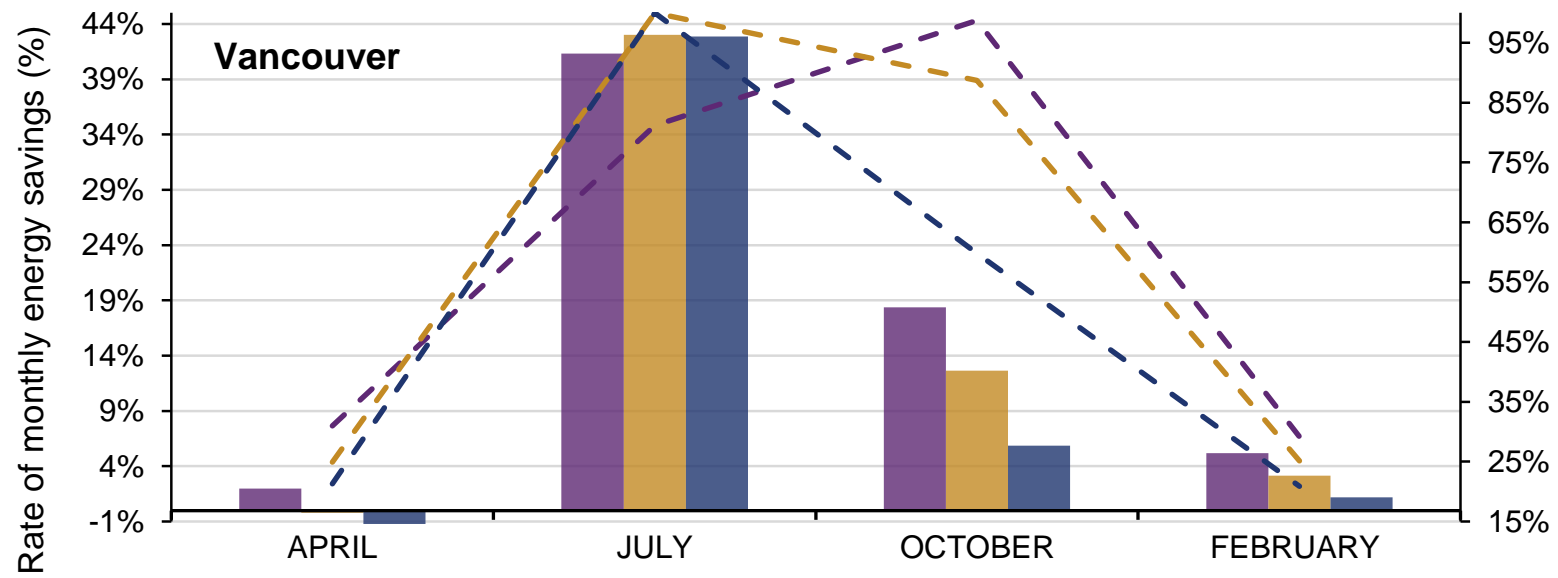

Figure 4.12. Monthly energy and peak load savings in the PCM integrated unit 
The impact of the composite PCM system in reducing daily temperature fluctuations is shown in Fig. 4.13. The figures demonstrate how operative temperature $\left(T_{o p}\right)$ swings are reduced in the PCM integrated unit. An average daily $T_{\text {op }}$ swing in a Toronto baseline unit with $80 \%$ WWR in October shows the wide range of temperature fluctuation is reduced from $4.6^{\circ} \mathrm{C}$ to $3.2^{\circ} \mathrm{C}$ with the application of the composite PCM system.

As WWRs get smaller, the overall range of temperature swings in a day is also reduced in baseline units, for instance in 40\% WWR units in Vancouver, average daily temperature swings are $2.8^{\circ} \mathrm{C}$ in the baseline unit while in the $80 \%$ WWR units average daily temperature fluctuation is $4.8^{\circ} \mathrm{C}$ in October. Correspondingly, it is observed from Fig. 4.13, that the effectiveness of the PCM in reducing daily swing is higher in $80 \%$ WWR units.
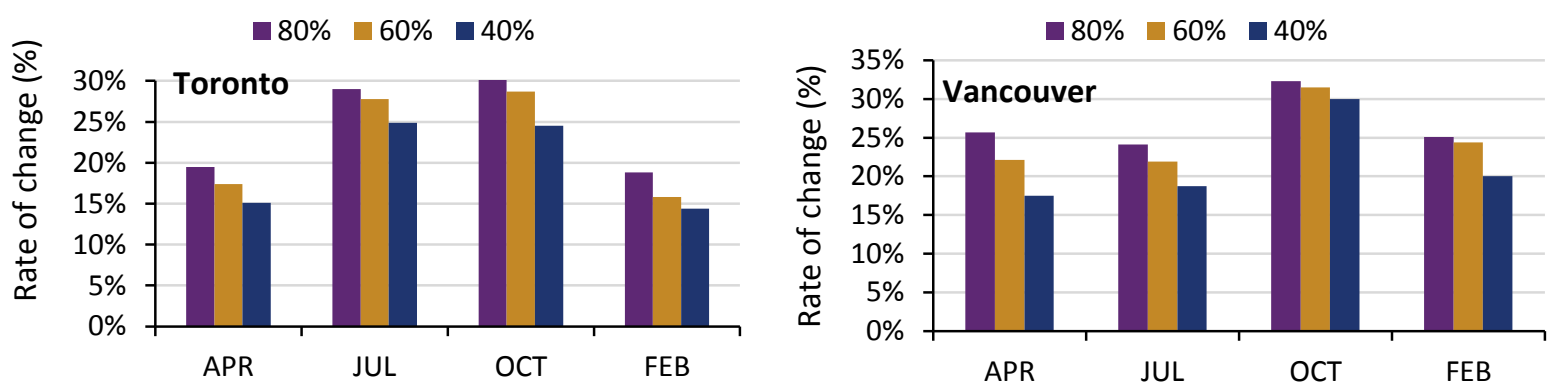

Figure 4.13. Rate of change in daily operative temperature swings in the PCM integrated unit

Overheating in the units was assessed by observing operative temperatures exceeding $26{ }^{\circ} \mathrm{C}$ during the day. Additionally, low peak temperature variations were analyzed by calculating the rate of change in operative temperatures falling below $21^{\circ} \mathrm{C}$. In Vancouver, in the entire month of October, the number of hours in which the $T_{o p}>26^{\circ} \mathrm{C}$ is reduced by 52 hours, this decrease is 48 hours in Toronto units in October. Comparing daily solar gain values in October and July in both cities regardless of WWR, it is observed that more direct solar penetration in rooms, and therefore higher solar gain, is available in October. Therefore, the number of hours with $\mathrm{T}_{\text {op }}>26$ ${ }^{\circ} \mathrm{C}$ in October is also higher in all units. For instance, in $80 \%$ WWR units which have a higher chance of overheating above $26{ }^{\circ} \mathrm{C}$, number of hours with overheating in the baseline Vancouver unit is only 2 hours in the entire month of July whereas in October, the baseline unit experience 96 hours with operative temperatures exceeding $26^{\circ} \mathrm{C}$.

It must be considered that in the case of $40 \%$ WWR units, indoor operative temperatures in the month of July does not rise above $26^{\circ} \mathrm{C}$ in the baseline unit and therefore no impact of PCMs could be recorded in this case. Considering lowest temperature peak of $21^{\circ} \mathrm{C}$ for operative temperatures, again the month of October shows better results in the PCM integrated unit. Specifically, in Vancouver units with $80 \%$ WWR, the number of hours in which the operative temperature falls below $21^{\circ} \mathrm{C}$ is reduced to 71 hours. Complete table for monthly high and low peak temperature variations is presented in Appendix I.

Overall, the results of peak temperature variation by adopting this composite PCM system shows a higher benefit in reducing high peak temperatures. Therefore, mitigation of daily temperature swings is more attributed to the decremental decrease of high peak temperatures rather than low peak temperature variations. It is evident that PCM integrated units with higher 
WWR in both cities have a better energy load reduction and indoor temperature regulation specifically in shoulder seasons. To understand the influencing factors on energy use and possible peak load shifting, hourly energy analysis is performed in the months of July, October, and February in both cities. Three consecutive days in each month are selected to observe energy use in each WWR scenario.

\section{Toronto}

As Table 4.6 shows, on three specific days, a linear relation exists, as solar gain is reduced in $40 \%$ WWR units, the effectiveness of the PCM system in reducing cooling energy gets higher. Considering a $53.7 \%$ less solar heat gain in $40 \%$ WWR, a total saving of $42 \%$ in cooling energy use is observed in the period of three days in July. This saving is $8 \%$ higher than the total cooling saving in the same days in units with $80 \%$ WWR. A similar pattern exists for days in February as the energy load decrease in $40 \%$ WWR units is also higher than other units. More detailed investigation on radiant and room temperatures is required, however high heat loss from highly glazed units might be a factor affecting heating energy use which degrades the effectiveness of the PCMs.

Table 4.6. Solar gain and energy use

\begin{tabular}{|l|c|c|c|c|c|c|}
\hline \multicolumn{1}{|c|}{ Toronto } & \multicolumn{2}{|c|}{$\mathbf{8 0} \%$} & \multicolumn{2}{c|}{$\mathbf{6 0 \%}$} & \multicolumn{2}{c|}{$\mathbf{4 0 \%}$} \\
\hline \multicolumn{1}{|c|}{3 Days } & $\begin{array}{c}\Delta \mathrm{E}_{\text {Saving }} \\
(\%)\end{array}$ & $\begin{array}{c}\text { Solar Gain } \\
\left(\mathbf{W} / \mathbf{m}^{2}\right)\end{array}$ & $\begin{array}{c}\Delta \mathrm{E}_{\text {Saving }} \\
(\%)\end{array}$ & $\begin{array}{c}\text { Solar Gain } \\
\left(\mathbf{W} / \mathbf{m}^{2}\right)\end{array}$ & $\begin{array}{c}\Delta \mathrm{E}_{\text {Saving }} \\
(\%)\end{array}$ & $\begin{array}{c}\text { Solar Gain } \\
\left(\mathbf{W} / \mathbf{m}^{2}\right)\end{array}$ \\
\hline $2^{\text {nd }}-4^{\text {th }}$ July & $34 \%$ & 8.8 & $37 \%$ & 6.3 & $42 \%$ & 4.08 \\
\hline $\begin{array}{l}3^{\text {rd }}-5^{\text {th }} \\
\text { October }\end{array}$ & $21 \%$ & 18.8 & $16 \%$ & 13.8 & $11 \%$ & 9.2 \\
\hline $\begin{array}{l}19^{\text {th }}-21^{\text {st }} \\
\text { February }\end{array}$ & $1 \%$ & 16.7 & $0 \%$ & 12.4 & $3 \%$ & 8.5 \\
\hline
\end{tabular}

Considering hourly cooling energy use from $2^{\text {nd }}-4^{\text {th }}$ of July in all three WWRs, no peak energy shift was observed in the three tested days. Nevertheless, a positive shift is observed at night on July $2^{\text {nd }}$, in which the cooling energy is eliminated at $10 \mathrm{pm}$ in the PCM integrated unit, whereas in the baseline unit cooling energy use reaches NET at 1 am on July $3^{\text {rd }}$. Similar elimination of active cooling is observed in $40 \%$ WWR unit at 12 am on July $4^{\text {th }}$ in the PCM integrated unit which is four hours ahead of the baseline unit reaching a NET cooling load.

Time of peak cooling energy load is approximately at the same time recorded for the peak solar gain in the units. Figure 4.14 a shows energy use from July $2^{\text {nd }}-4^{\text {th }}$ in $80 \%$ WWR units, as indicated on July $2^{\text {nd }}$ and July $4^{\text {th }}$, highest cooling energy use in both baseline and PCM integrated units is at the same time of highest solar gain in the units. The only difference in the pattern of energy use in $60 \%$ and $40 \%$ WWR units is the elimination of cooling and the decrease of peak load energy's periods, while the peak shifting pattern is the same as highlighted in Fig 14a. Positive load shift indicates energy use starting later in the PCM integrated unit or being eliminated, meaning passive cooling by PCM integration. Negative load shift shows energy use starting earlier in the PCM integrated unit or full use of cooling/heating systems in the PCM integrated unit when baseline unit has no energy use, meaning a $100 \%$ full load energy use in PCM integrated unit. 


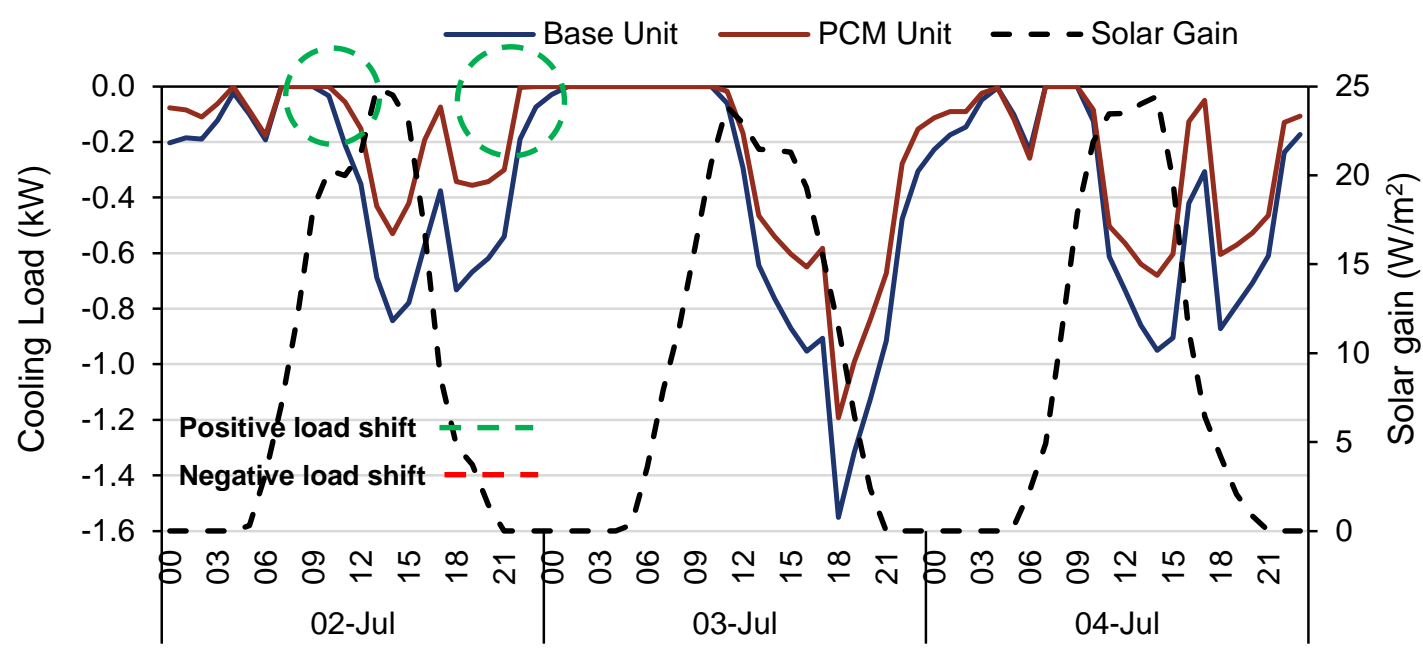

a) Energy use and solar gain in $80 \%$ WWR Toronto unit in July

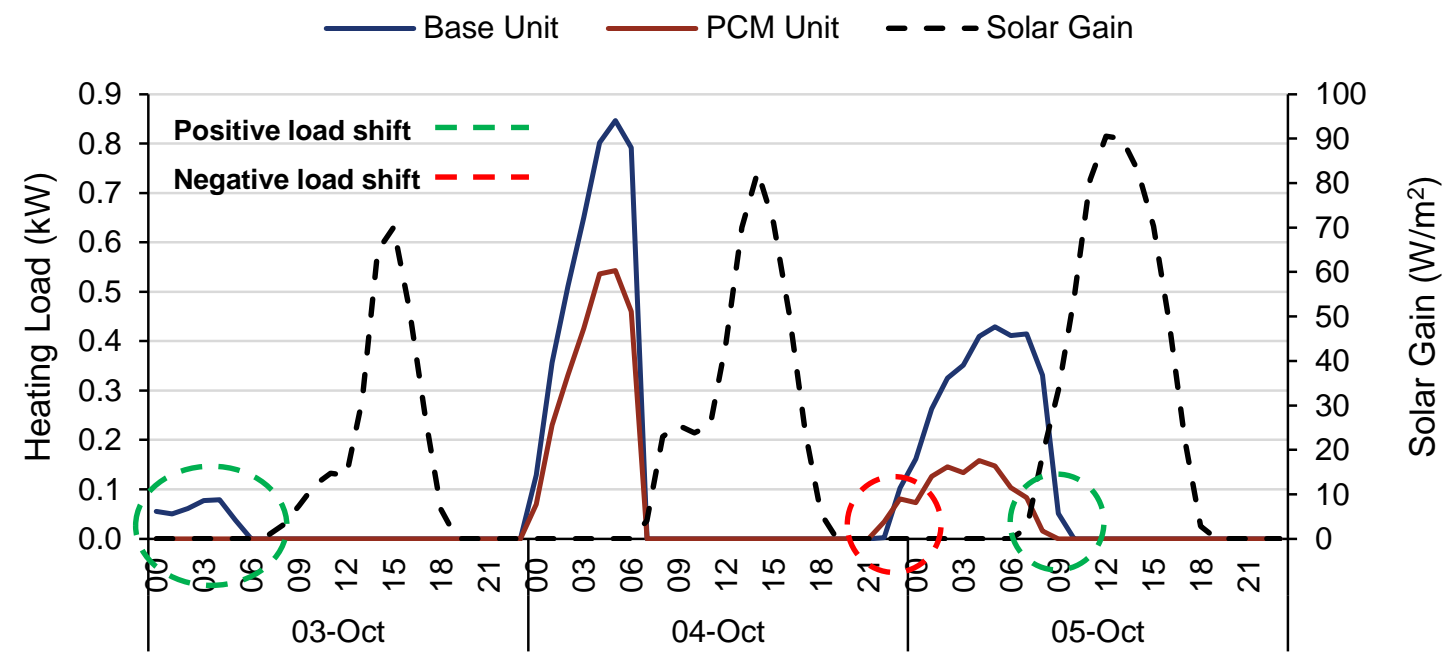

b) Energy use and solar gain in $80 \%$ WWR Toronto unit in October

Figure 4.14. Energy use and peak shifting in three day periods- Toronto Units

Figure 4.14b shows heating energy load variations in $80 \%$ WWR units from October $3^{\text {rd }}-5^{\text {th }}$. The impact of solar gain in the month of October is evident as no heating is required during the day due to high solar gain in the units. Major energy saving by integrating the composite PCM system occurs at night with $0.41 \mathrm{~kW}$ decreased peak heating loads in early morning on October $4^{\text {th }}$. The pattern of energy use and time of day corresponds to the pattern of melting and solidification of PCMs, as shown in the figure, lower heating is required at night in the PCM integrated unit as the composite PCM system releases the absorbed heat back to the space, lowering heating loads in the space. Furthermore, relation of solar gain changes to energy demand is clear in Fig. 4.14b, as peak solar gain is increased on October $4^{\text {th }}$ compared to $3^{\text {rd }}$ by $12 \mathrm{~W} / \mathrm{m}^{2}$, night heating energy is decreased by $0.4 \mathrm{~kW}$ in the baseline unit. However, the peak energy reduction in the PCM integrated unit is similar in both days with a $0.3 \mathrm{~kW}$ decrease in heating loads in both days. 

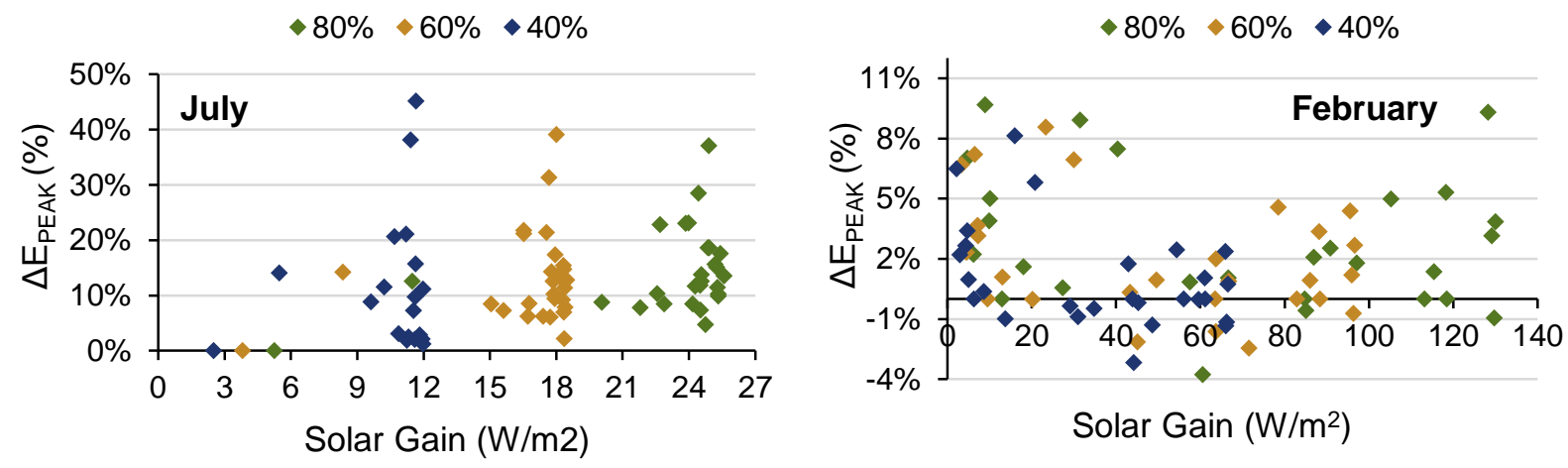

Figure 4.15. Correlation of average monthly peak load saving and solar gain- Toronto

In addition to energy use, the most influential parameter to be investigated is radiant temperature variations. Considering October $3^{\text {rd }}$ and $4^{\text {th }}$ as shown in Fig. 14b, operative, and radiant temperature variations are compared. Throughout the days, operative temperatures in both baseline and PCM integrated units are lower than radiant temperatures. By looking at the trend of temperature changes in Figure 4.16, it is evident that during the night, as temperatures in the baseline unit drop below $23^{\circ} \mathrm{C}$, the radiant temperatures in the PCM integrated unit is kept constant at nearly $24.5^{\circ} \mathrm{C}$ for 9 hours on October $3^{\text {rd }}$. Considering the melting temperature range of the PCM products in the composite PCM system, the heat storage and release observed on this day are attributed to Bio PCM layer with melting range of $21-25^{\circ} \mathrm{C}$.

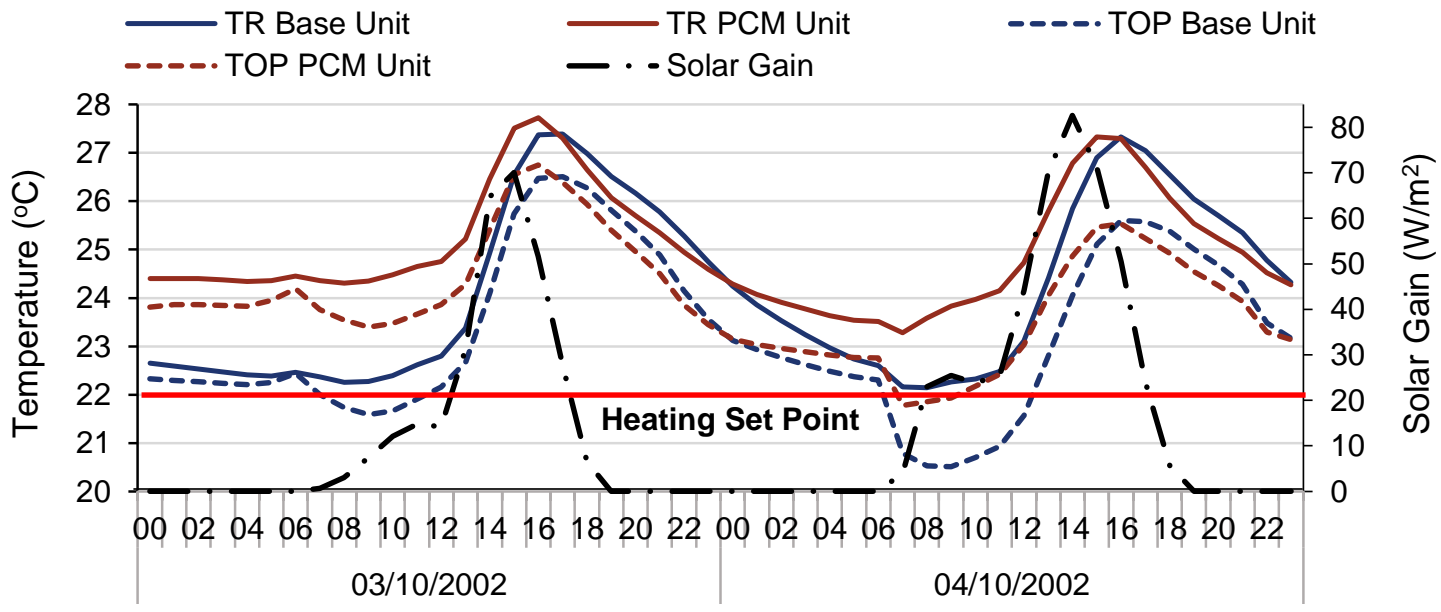

Figure 4.16. Radiant and operative temperature changes on October $3^{\text {rd }}-4^{\text {th }}$

As operative temperatures in the baseline unit start to drop below $22^{\circ} \mathrm{C}$ shown in Fig. $4.16-$ Heating set point; the energy demand starts to rise from Midnight to $7 \mathrm{am}$ on the $4^{\text {th }}$. Lower early morning temperatures on the $4^{\text {th }}$ lead to higher chance of solidification for the Bio PCM product that results in better energy and temperature changes due to higher storage in the next cycle. Even if the PCM is not entirely solidified, the gap between radiant and operative temperature in the PCM integrated units shows a higher chance of PCM activation on the $4^{\text {th }}$. Moreover, peak energy use on the $4^{\text {th }}$ at night is lower compared to $3^{\text {rd }}$ as room operative temperatures are kept constant for longer. 
With an increase of $12.51 \mathrm{~W} / \mathrm{m}^{2}$ in maximum solar gain on the $4^{\text {th }}$, the gap between $T_{\text {op }}$ and $T_{R}$ is increased to $1.9^{\circ} \mathrm{C}$ compared to July $3^{\text {rd }}$ in which this gap is $0.9^{\circ} \mathrm{C}$. Additionally, higher solar gain on July $4^{\text {th }}$ does not necessarily indicate higher indoor operative temperature in the units. On July $4^{\text {th }}$, indoor operative temperatures are closer to the range of the Bio PCM product, with a lower average in both baseline and PCM integrated units compared to July $3^{\text {rd }}$.

\section{Vancouver}

The same analysis for Vancouver units shows a contrasting behavior in the PCM integrated units in July. Reduction of solar heat gain in the units with lower WWR leads to lower rate of energy savings in the PCM integrated unit compared to higher WWR units. One explanation is lower operation of cooling systems in $40 \%$ WWR units in Vancouver indicating less occurrence of change by the composite PCM system. The other reason is the indoor room and surface temperatures that fall less in the range of the Bio PCM layer to be activated in $40 \%$ WWR units showing less PCM function. In October, however, the relation of solar gain and energy saving is similar in Vancouver PCM integrated units to the Toronto units.

Figure 4.17a shows the cooling energy variation and solar gain changes from July $2^{\text {nd }}-4^{\text {th }}$ in $80 \%$ WWR units with the highest rate of saving in the PCM integrated unit as stated by Table 4.7. The highlighted areas in the figure show how the energy use is shifted both positively and negatively, this rate of change as highlighted in $80 \%$ WWR units does not appear in the same period in $40 \%$ WWR unit. Considering peak cooling energy use and highest solar intensity in the rooms, it is evident that the peak energy occurs in approximately 7 hours after the highest solar gain in the units are reached. However, it should be noted that cooling with main set point temperature of $24^{\circ} \mathrm{C}$ starts at $6 \mathrm{pm}$ on each day, therefore the peak energy illustrated in the graph show the start of the cooling.

Table 4.7. Solar gain and Average total energy use

\begin{tabular}{|l|c|c|c|c|c|c|}
\hline \multicolumn{1}{|c|}{ Vancouver } & \multicolumn{2}{|c|}{$\mathbf{8 0 \%}$} & \multicolumn{2}{c|}{$\mathbf{6 0 \%}$} & \multicolumn{2}{c|}{$\mathbf{4 0 \%}$} \\
\hline 3 Days & $\begin{array}{c}\Delta \mathrm{E}_{\text {Saving }} \\
(\%)\end{array}$ & $\begin{array}{c}\text { Solar Gain } \\
\left(\mathbf{W} / \mathbf{m}^{2}\right)\end{array}$ & $\begin{array}{c}\Delta \mathrm{E}_{\text {Saving }} \\
(\%)\end{array}$ & $\begin{array}{c}\text { Solar Gain } \\
\left(\mathbf{W} / \mathbf{m}^{2}\right)\end{array}$ & $\begin{array}{c}\Delta \mathrm{E}_{\text {Saving }} \\
(\%)\end{array}$ & $\begin{array}{c}\text { Solar Gain } \\
\left(\mathbf{W} / \mathbf{m}^{2}\right)\end{array}$ \\
\hline $2^{\text {nd }}-4^{\text {th }}$ July & $21.3 \%$ & 9.7 & $13.2 \%$ & 7 & $7.8 \%$ & 4.4 \\
\hline $\begin{array}{l}3^{\text {rd }}-5^{\text {th }} \\
\text { October }\end{array}$ & $9.7 \%$ & 17.9 & $6.8 \%$ & 13.2 & $2.9 \%$ & 9.05 \\
\hline $\begin{array}{l}19^{\text {th }}-21^{\text {st }} \\
\text { February }\end{array}$ & $3.7 \%$ & 21.5 & $9.5 \%$ & 16.2 & $10.2 \%$ & 11.2 \\
\hline
\end{tabular}

Even though the peak of cooling load on all the three days tested in July occurs at 6 pm in both units, a positive load shift occurs on each day as the cooling starts an hour later and stops an hour earlier at $10 \mathrm{pm}$ in the PCM integrated unit. Solar gain changes on July $4^{\text {th }}$ show that a non-linear relation exists between energy use in both baseline and PCM integrated units.

In the heating season, negative peak load shifting was observed in the investigated days in October and February in the PCM integrated unit. The aim for peak shifting in residential apartments is to delay the peak energy use from peak electricity periods to off-peak periods. However, the results of this study on specific daily periods have shown peak shifting or load shifting at electricity off-peak periods. Thus, the term load shifting used simply refers to the 
energy use shifted in time in the PCM integrated unit, which indicates passive cooling or heating by using the PCM system. For instance, on three consecutive days in October in $80 \%$ WWR units, a high energy saving is observed in the PCM integrated on October $3^{\text {rd }}$, however, two negative peak load shifting are observed on $4^{\text {th }}$ and $5^{\text {th }}$ of October as shown in Fig.4.17b.

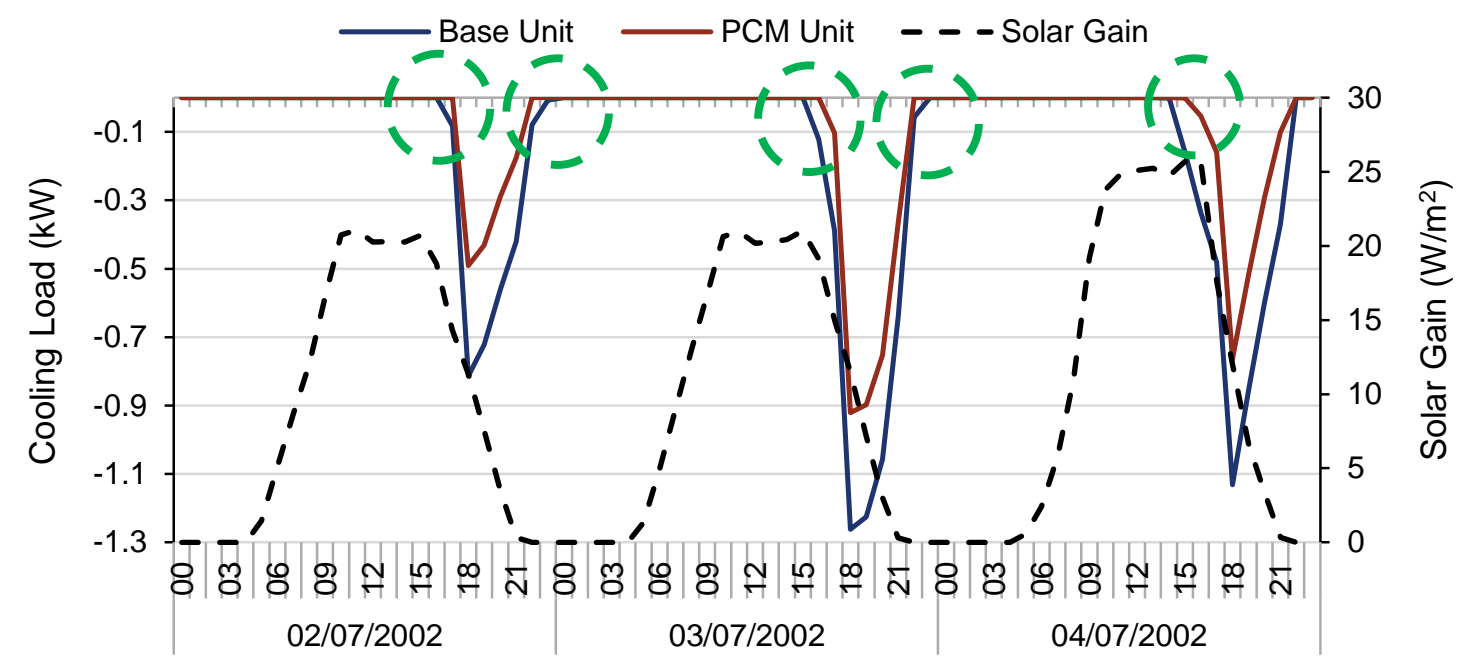

a) Energy use and solar gain in $80 \%$ WWR Vancouver unit- July

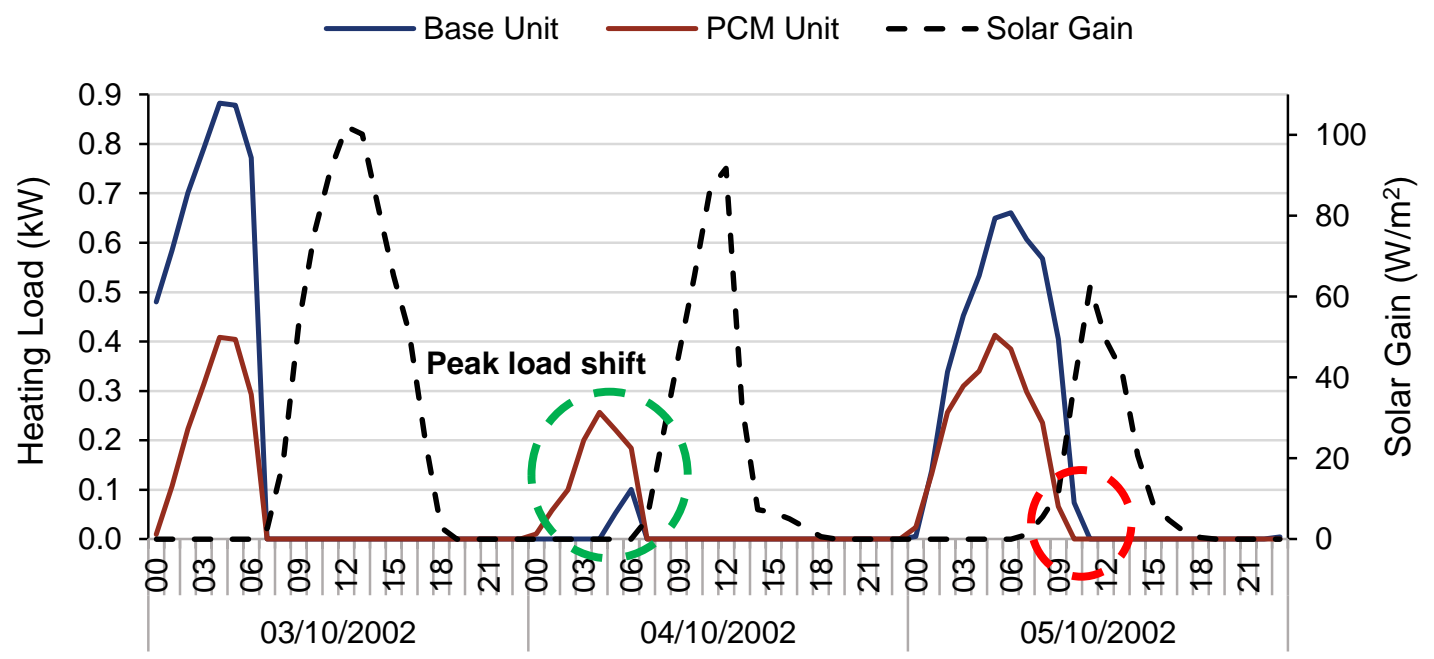

b) Energy use and solar gain in $80 \%$ WWR Vancouver unit- October

Figure 4.17. Energy use and peak shifting in three day periods- Vancouver Units

Figure 4.17 shows that on October $4^{\text {th }}$ at $12 \mathrm{am}$, heating systems start to operate in the PCM integrated unit 5 hours earlier than the start of heating in the baseline unit. By observing the operative temperatures in the units, a low temperature of $23^{\circ} \mathrm{C}$ is observed in the PCM integrated unit while the temperature in the baseline unit is $25^{\circ} \mathrm{C}$ at $12 \mathrm{am}$. Therefore, the system starts to heat the room until 7 am when the heating system changes to set back temperature which is $18^{\circ} \mathrm{C}$ prompting the systems to stop operating. This negative peak shift 
indicates a higher chance for the PCMs in reducing high peak temperatures during the day resulting in lower room temperatures. Another explanation is lack of PCM melting during the day due to lower outdoor temperatures, thus the PCM starts to melt at night drawing the heat of the system in operation.

In addition to solar gain variation in units, the most important parameter affecting the activation of PCMs is indoor air temperatures, therefore a detailed monthly temperature analysis is performed in each WWR scenario to explain the activation of the composite PCM system.

Figures 4.18 and 4.19 show temperature profile for a window facing wall of an apartment unit in October, drawn in relation to room operative temperature. (Only the operative temperature of the PCM integrated room is shown)
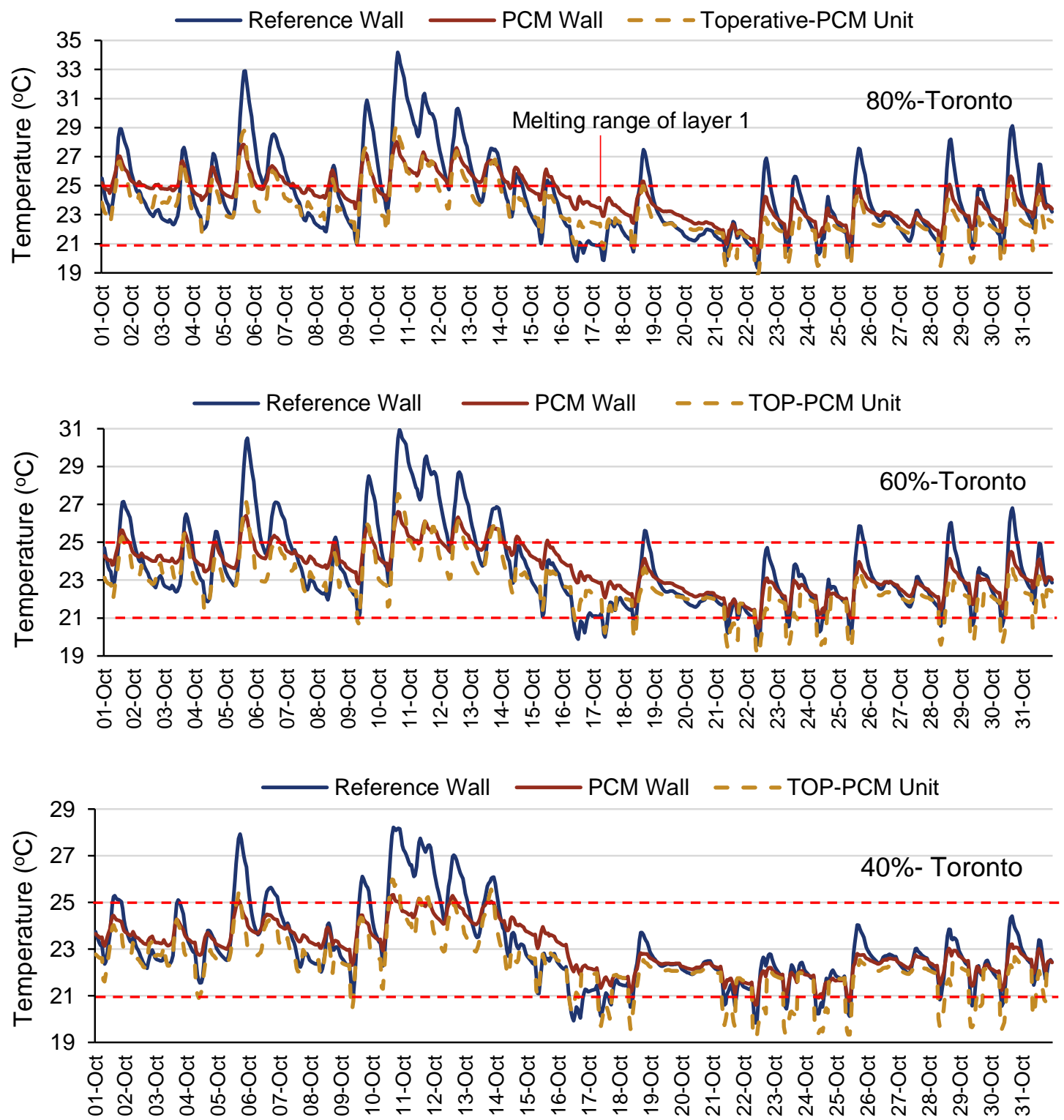

Figure 4.18. Wall surface temperatures and operative temperatures in Toronto 
Considering high indoor temperatures in the month of October in all units in both Vancouver and Toronto, the melting range of Bio PCM is considered in the above figures. The melting threshold for this product as discussed before, ranges from $21^{\circ} \mathrm{C}$ to $25^{\circ} \mathrm{C}$. As shown previously in Fig. 4.12, in October in both cities, energy savings and peak energy load reductions are higher in $80 \%$ WWR units. Considering the monthly results shown in Fig. 4.18, it could be inferred that Bio PCM may not fully melt in $40 \%$ and $60 \%$ WWR units as the wall surface temperatures stay within the melting range which is assumed to be an interface between the phase transition.

Comparing the PCM integrated wall surface temperature and room operative temperature, average surface temperature is always higher in the PCM surface compared to the room operative temperatures. The figures above show how the PCM wall and the room operative temperatures are within a constant range, close to the melting range of the Bio PCM product. Due to high room temperatures shown, the melting or solidification may not be complete.
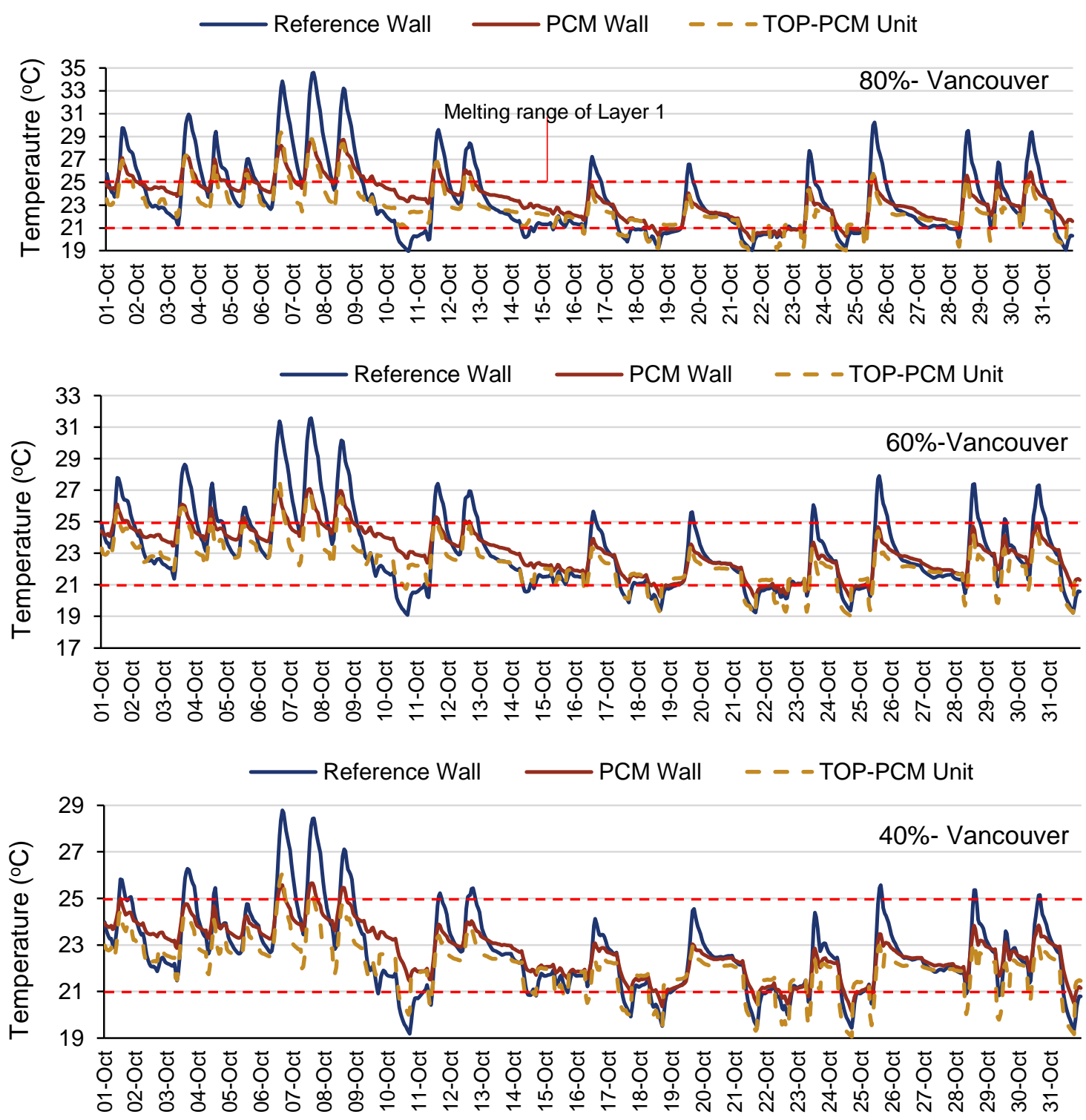

Figure 4.19. Wall surface temperatures and operative temperatures (Top) in Vancouver 


\subsubsection{Study \#2: Effect of orientation on PCM performance}

To study the impact of orientation on PCM behavior, $80 \%$ WWR units are simulated in four directions of north, east, and west in addition to the south. As discussed, the effectiveness of the composite PCM system on an annual basis considering both heating and cooling energy loads and particularly indoor temperature regulations is higher in $80 \%$ WWR units. To assess the rate of change in the PCM integrated unit in different orientations, south facing units are considered as a point of reference, thus the percentage of change in the PCM integrated units facing other orientations is compared to the south orientation unit.

Considering annual energy consumption in the baseline unit with no PCMs, a significant rise is observed in units facing the other three orientations. For instance, in Toronto, north facing baseline unit has an annual EUI of $206.5 \mathrm{kWh} / \mathrm{m}^{2}$, which is $23 \%$ higher than the baseline unit facing south. A comparable trend is observed in Vancouver with significantly higher EUI of $141.6 \mathrm{kWh} / \mathrm{m}^{2}$ in west facing baseline unit, $26 \%$ higher than the south facing baseline unit.

Total reduction in annual EUI in the PCM integrated unit facing west is only $0.7 \%$ which marks the lowest reduction in annual EUI compared to other orientations in Toronto. In both west and north facing units, integration of the composite PCM system entails a negative impact on annual heating EUI. Regarding cooling energy use, east facing units perform worst than other orientations as both baseline and PCM integrated units have very high cooling energy loads which further degrades the potential of the PCMs to save cooling energy. For instance, in Toronto units facing east cooling energy saving in the PCM integrated unit is $10.5 \%$ which is $22 \%$ lower than the saving in south facing units in June.

In Vancouver, annual EUI reduction is lowest in the north facing units with only $0.6 \%$ total saving by application of the PCMs. Paradoxically, total cooling energy saving is quite high in north facing units with a $40 \%$ reduction in annual cooling load which is higher than savings in south facing units on cooling energy. This is mainly due to lower cooling demands for the first two weeks of September which has led to $85 \%$ total saving in the PCM integrated unit facing north in this month which is higher than units facing other orientations. The lowest performance of the composite PCM system in heating season is recorded in the north facing units with monthly savings lower than $1 \%$ in fall months and negative heating changes in winter.

Cooling energy consumption is considerably higher in the west and east facing units in Toronto and Vancouver units. Particularly in Vancouver units facing west, cooling energy load is increased to $510 \mathrm{kWh}$ in the month of July which is extremely higher than the south cooling load $80.5 \mathrm{kWh}$ in the baseline unit in July. Furthermore, in contrast to the south facing Vancouver units, peak load energy use in other orientations is observed in the month of July. In heating months starting from January, north facing units have the highest energy load as expected due to no direct solar gain in these units.

Detailed monthly analysis in Study \#1 showed a high PCM performance in the month of October in heating season and in July in the cooling season, these two months are selected for an hourly analysis. Monthly energy consumption in October and July demonstrated in Table 4.8 shows a linear trend of decrease in PCM's impact in reducing cooling energy as the units are rotated from south to west orientation. 
Table 4.8 shows the intense solar exposure in east and west facing units, particularly at sunrise and sunset periods. Correspondingly the percentage of energy saving in the PCM integrated unit shows a declining trend as solar gain is increased in the units. It was suggested in study \#1 that by changing glazing ratio and thus increasing incoming solar gain in units, positively affects PCM performance. Therefore, comparing those results and the results shown in this section it could be inferred that peak solar radiation and time of peak solar radiation impacts the composite PCM's behavior differently.

Table 4.8. Change in monthly energy consumption in the PCM integrated unit

\begin{tabular}{|c|c|c|c|c|c|c|c|c|}
\hline \multicolumn{9}{|c|}{ Vancouver Units } \\
\hline Orientation & \multicolumn{2}{|c|}{ South Facing } & \multicolumn{2}{|c|}{ North Facing } & \multicolumn{2}{|c|}{ East Facing } & \multicolumn{2}{|c|}{ West Facing } \\
\hline Variable & $\begin{array}{c}\Delta E_{\text {Saving }} \\
(\%)\end{array}$ & $\begin{array}{l}\text { Solar } \\
\text { gain } \\
\left(\mathrm{W} / \mathrm{m}^{2}\right)\end{array}$ & $\begin{array}{c}\Delta E_{\text {Saving }} \\
(\%)\end{array}$ & $\begin{array}{l}\text { Solar } \\
\text { gain } \\
\left(\mathrm{W} / \mathrm{m}^{2}\right)\end{array}$ & $\begin{array}{c}\Delta E_{\text {Saving }} \\
(\%)\end{array}$ & $\begin{array}{l}\text { Solar } \\
\text { gain } \\
\left(\mathrm{W} / \mathrm{m}^{2}\right)\end{array}$ & $\begin{array}{c}\Delta E_{\text {Saving }} \\
(\%)\end{array}$ & $\begin{array}{l}\text { Solar } \\
\text { gain } \\
\left(\mathrm{W} / \mathrm{m}^{2}\right)\end{array}$ \\
\hline July & $41.3 \%$ & 9.1 & $29.9 \%$ & 10.5 & $12 \%$ & 18.1 & $5.8 \%$ & 22.1 \\
\hline October & $18.4 \%$ & 12.3 & $0.2 \%$ & 2.9 & $4.7 \%$ & 6.3 & $0.7 \%$ & 5.3 \\
\hline \multicolumn{9}{|c|}{ Toronto Units } \\
\hline Orientation & \multicolumn{2}{|c|}{ South Facing } & \multicolumn{2}{|c|}{ North Facing } & \multicolumn{2}{|c|}{ East Facing } & \multicolumn{2}{|c|}{ West Facing } \\
\hline Variable & $\begin{array}{c}\Delta E_{\text {Saving }} \\
(\%)\end{array}$ & $\begin{array}{l}\text { Solar } \\
\text { gain } \\
\left(\mathrm{W} / \mathrm{m}^{2}\right)\end{array}$ & $\begin{array}{c}\Delta E_{\text {Saving }} \\
(\%)\end{array}$ & $\begin{array}{l}\text { Solar } \\
\text { gain } \\
\left(\mathrm{W} / \mathrm{m}^{2}\right)\end{array}$ & $\begin{array}{c}\Delta E_{\text {Saving }} \\
(\%)\end{array}$ & $\begin{array}{l}\text { Solar } \\
\text { gain } \\
\left(\mathrm{W} / \mathrm{m}^{2}\right)\end{array}$ & $\begin{array}{c}\Delta E_{\text {Saving }} \\
(\%)\end{array}$ & $\begin{array}{l}\text { Solar } \\
\text { gain } \\
\left(\mathrm{W} / \mathrm{m}^{2}\right)\end{array}$ \\
\hline July & $6.7 \%$ & 8.5 & $5 \%$ & 9.6 & $3.9 \%$ & 17.4 & $0.5 \%$ & 15.7 \\
\hline October & $13.4 \%$ & 14.8 & $1 \%$ & 4.4 & $5.3 \%$ & 8.6 & $2.9 \%$ & 8.8 \\
\hline
\end{tabular}

To compare the effect of solar gain and peak solar periods on cooling and heating energy loads, one day in October and one day in July are analyzed. In addition, temperature variations are also assessed to examine the rate of change in indoor thermal comfort conditions. First considering units in Toronto, hourly rate of energy changes is compared to hourly solar gain variations on July $3^{\text {rd }}$ and October $5^{\text {th }}$ as shown in Figure 4.20. It must be noted that a $-100 \%$ rate of change means the operation of HVAC systems in PCM integrated unit as opposed to no HVAC operation in the baseline unit at the same time.

Matching peak energy loads with peak solar gain is not accurate as the HVAC system used in the model runs on a schedule, thus the starting point of the system at $6 \mathrm{pm}$ on main set point temperature is the peak load recorded for all the studied days in both seasons. However, comparing maximum operative temperatures during the day with solar gain periods better illustrates the relation.

Figure 4.20a shows an average savings of $35 \%$ in cooling load in the east facing units as solar gain reaches its peak in the early morning hours from 6 to $10 \mathrm{am}$. As the solar radiation gets into the room from $7 \mathrm{am}$, the same time that cooling system turns into setback temperature, the surface temperature of PCM integrated walls and ceiling stabilize and during 10 hours only change by $0.4^{\circ} \mathrm{C}$. The significant stabilization of the radiant temperature, in turn, affects the air 
temperature in the unit indicating a lower demand for cooling energy. Overall low energy saving in west facing units was analyzed by observing surface temperature variations. Higher surface temperatures at night prevent the full or partial solidification of the PCM integrated surfaces. A calculation showed that $98 \%$ of the time in July, PCM wall surface temperatures are in liquid state in the west facing unit.

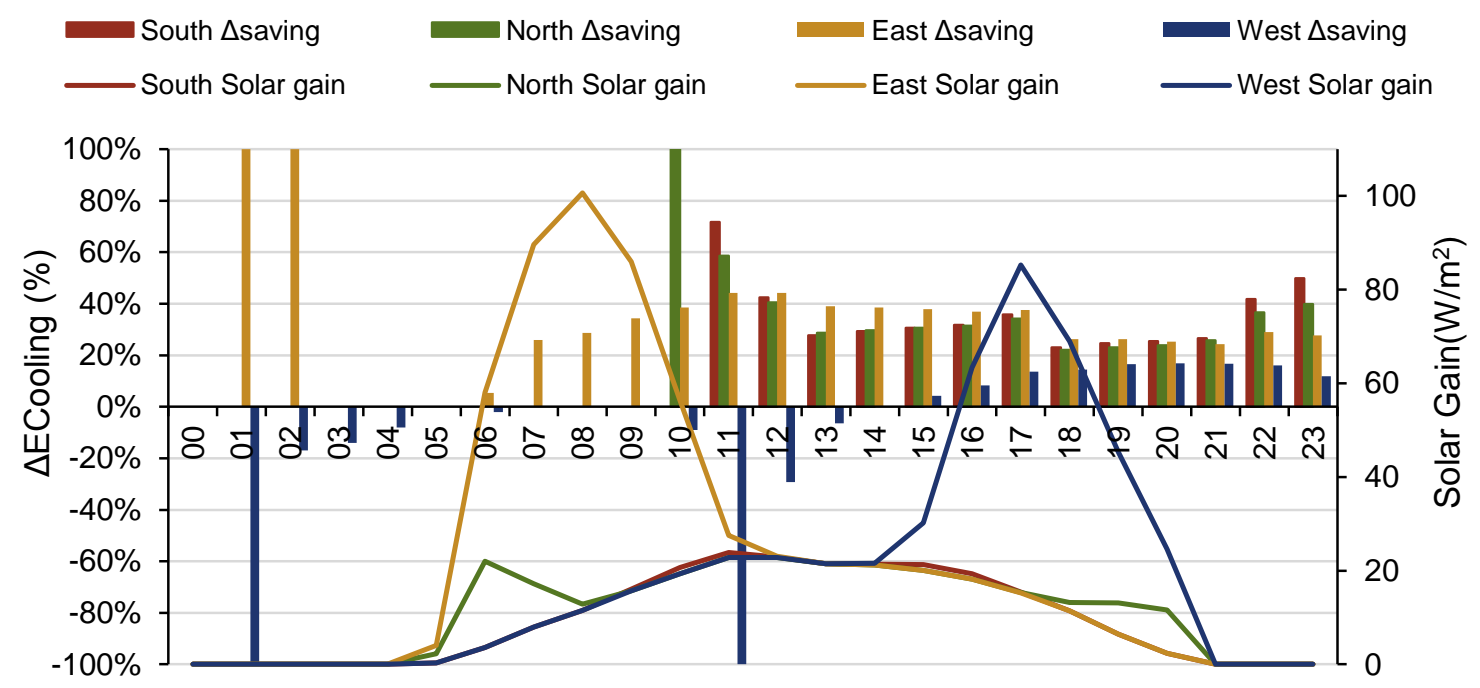

a) July $3^{\text {rd }}$

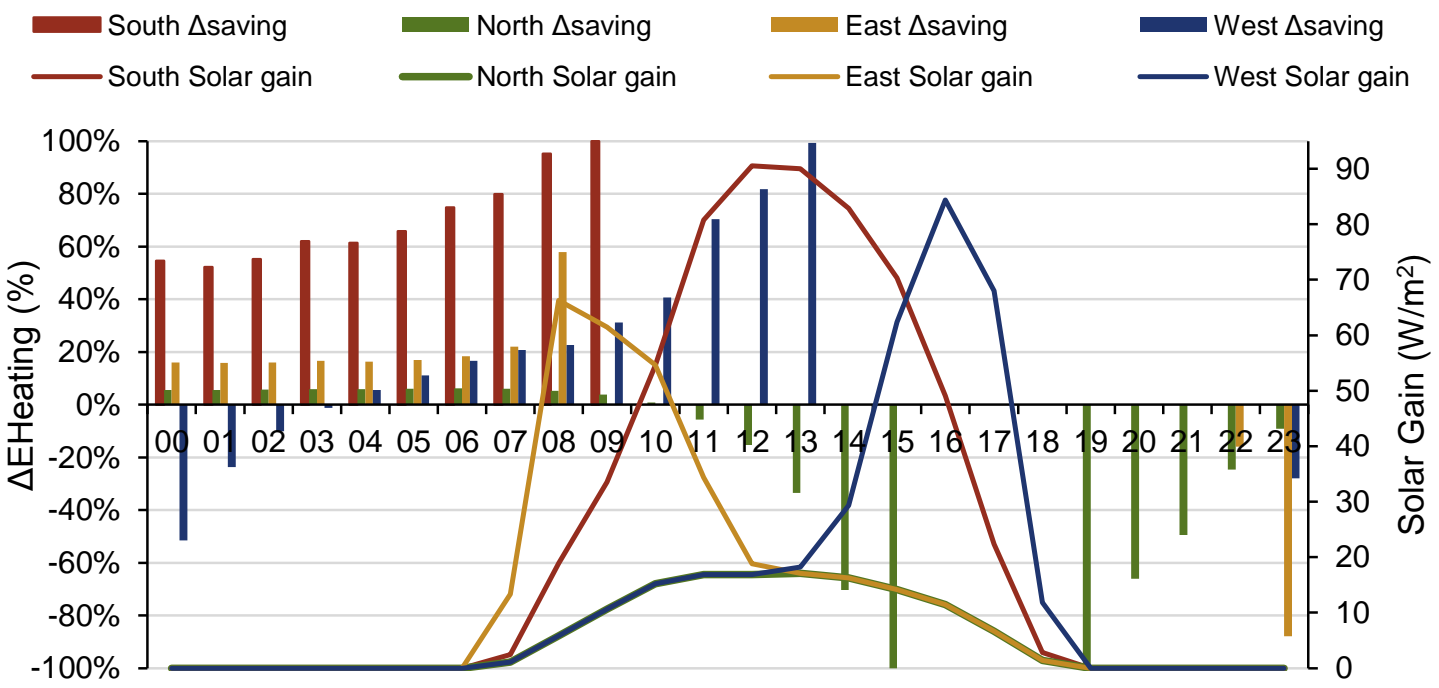

b) October $5^{\text {th }}$

Figure 4.20. Solar gain and rate of cooling energy saving in PCM integrated unit- Toronto

In Fig. $4.20 \mathrm{~b}$ mostly $0 \%$ rate of change in heating energy loads in the October day is recorded as sufficient solar gain in the unit allows for removal of heating demand when the units face south and east. In the west facing unit, however, during early morning hours after midnight, stable temperatures in the PCM integrated unit allows for lower heating demands. Specifically, as surface temperatures are kept constant at $23.5^{\circ} \mathrm{C}$ for 13 hours which allows for partial solidification of the composite PCM system returning the absorbed heat back to the space. In 
south, east and west facing orientation, PCM solidification at night period allows for reduction of heating energy as the stored heat in the composite PCM system compensates for the heat loss from the room at night. However, in north facing unit on October $5^{\text {th }}$, hourly energy changes in the PCM integrated units are negative which is a result of more heating system operation as the PCM system stores energy produced by the heating system. Temperature variations in the baseline and PCM integrated unit which shows a lower surface temperature in PCM integrated walls from $11 \mathrm{am}$ to $22 \mathrm{pm}$ at night which causes the higher energy demand.

A similar trend is observed on July $3^{\text {rd }}$ and October $5^{\text {th }}$ in Vancouver (full graphs are presented in Appendix I). One of the parameters of analysis considered to evaluate PCM performance in this study is the "Frequency of PCM activation", which was first introduced by Evola et al. (2013). This parameter determines the rate of PCM activation based on nominal melting point of the PCM and the actual measured surface temperature. The frequency of activation of the PCM integrated ceiling and a window facing wall in the units are calculated and plotted in Fig. 4.21 in July and October. This figure shows the activation of the Bio PCM or layer 1 of the composite PCM system.
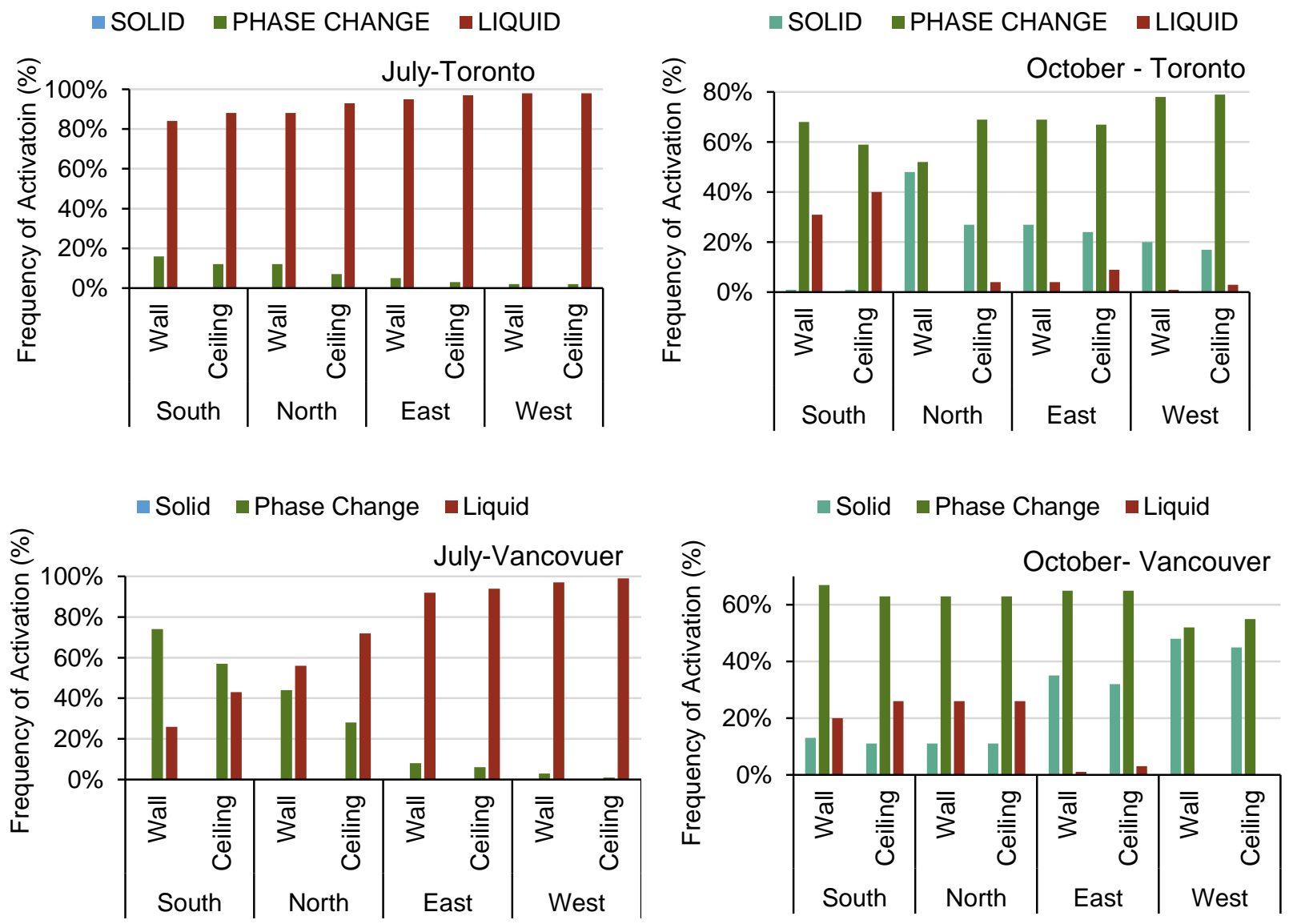

Figure 4.21. Frequency of activation of PCM integrated ceiling and wall

Higher surface temperatures in the PCM integrated ceiling results in higher percentage of time in which layer 1 stays melted. Particularly in July due to higher temperatures and specifically in west facing units both ceiling and wall surfaces experience an average of $85 \%$ liquid state. In October, however, a high percentage of phase change or PCM activation is observed. Due to 
colder conditions in north facing units, instances of PCMs being in solid state is also higher particularly in the walls showing $48 \%$ solid state. Ironically higher percentage of activation and lower chances of PCMs staying in melted state in west facing units in October could be related to shorter direct solar periods in the units thus no overheating or high temperature extremes.

Lower ambient and indoor temperatures, as well as lower solar gain in Vancouver, result in a significantly higher frequency of activation in both wall and ceiling in July. Nevertheless, like Toronto units in July, the PCM wall or ceiling is never in the solid state and the results in west facing units show a $100 \%$ liquid state in both ceiling and wall. The west facing units as shown in Table 4.8 experience the highest solar gain in both months which also decreases the chance of activation in October. Solar gain near sunset at west facing units are much higher than the sunrise period in east facing units.

As discussed surface temperatures of the PCM integrated surfaces in west facing units have higher night temperatures. In summer months, this is due to lack of solidification, however, in winter, highest surface temperatures are experienced during the sunset period from 3- $6 \mathrm{pm}$ as shown in October. Melting of the PCMs at later times during the day allows for the PCM to retain its temperature for a longer period during the night which results in higher heating load saving.

By observing hourly solar gain and surface temperature variations, peak temperatures in the units are one hour apart from peak solar gain values entering the unit in all orientations, except in west facing units. In west facing units, peak solar gain and peak surface temperatures are recorded at the same time in the majority of days. Nevertheless, this correlation is not accurate as the surface temperatures are not only dependant on solar gain and are influenced by indoor air variations as well.

\subsubsection{Study \#3: HVAC set point temperatures and PCM activation}

Solar gain has considerable influence on PCM effectiveness as discussed in previous sections, however, indoor boundary conditions controlled by conditioning systems is an important parameter directly in contact with the PCM integrated surfaces. While outdoor weather conditions dictate the performance of conditioning systems they do not directly affect PCM performance in conditioned buildings as opposed to free running buildings. In study \#3, the dynamic behavior of the composite PCM system is tested through changing heating and cooling set points to find the most suitable indoor boundary conditions for maximum performance. In this study, south facing units with $80 \%$ WWR are tested.

The primary heating and cooling set points tested so far have been $22{ }^{\circ} \mathrm{C}$ for heating and $24{ }^{\circ} \mathrm{C}$ for cooling. As the melting range of the composite PCM system varies between $18-25^{\circ} \mathrm{C}$, other room air set point options must cycle close to this range to ensure PCM activation. Residential apartments tested in this study have an intermittent occupancy, which according to Hoes and Hensen (2016), could ensure a better PCM activation. During occupancy periods, main set point temperature is considered for the systems and in other periods during the day, heating and cooling systems run on a set back temperature. Table 4.9 shows three heating and cooling set point options by varying both main and set back temperatures. 
Table 4.9. Alternative heating and cooling set points

\begin{tabular}{|c|c|c|c|c|c|c|c|c|}
\hline \multicolumn{9}{|c|}{ Fan coil set point temperatures } \\
\hline $\begin{array}{l}\text { Set point } \\
\text { Scnearios }\end{array}$ & Primary & cenario & Scenari & 1 (SCE1) & $\begin{array}{r}\text { Scer } \\
\text { (S }\end{array}$ & $\begin{array}{l}\text { ario } 2 \\
\text { E2) }\end{array}$ & $\begin{array}{l}\text { Scer } \\
\text { (SC }\end{array}$ & $\begin{array}{l}\text { ario } 3 \\
\text { E3) }\end{array}$ \\
\hline Mode & Heating & Cooling & Heating & Cooling & Heating & Cooling & Heating & Cooling \\
\hline $\begin{array}{l}\text { Main Set Point } \\
\text { Temperature }\end{array}$ & $22^{\circ} \mathrm{C}$ & $24^{\circ} \mathrm{C}$ & $21^{\circ} \mathrm{C}$ & $25^{\circ} \mathrm{C}$ & $23^{\circ} \mathrm{C}$ & $26{ }^{\circ} \mathrm{C}$ & $20^{\circ} \mathrm{C}$ & $23^{\circ} \mathrm{C}$ \\
\hline $\begin{array}{l}\text { Setback } \\
\text { Temperature }\end{array}$ & $18^{\circ} \mathrm{C}$ & $25^{\circ} \mathrm{C}$ & $17^{\circ} \mathrm{C}$ & $26^{\circ} \mathrm{C}$ & $20^{\circ} \mathrm{C}$ & $27^{\circ} \mathrm{C}$ & $16^{\circ} \mathrm{C}$ & 24 \\
\hline
\end{tabular}

Monthly energy use in both cities are illustrated in Figures 4.22 and 4.23 which is correlated with operative temperature changes and peak temperature variations in Table 4.10 and 4.11.
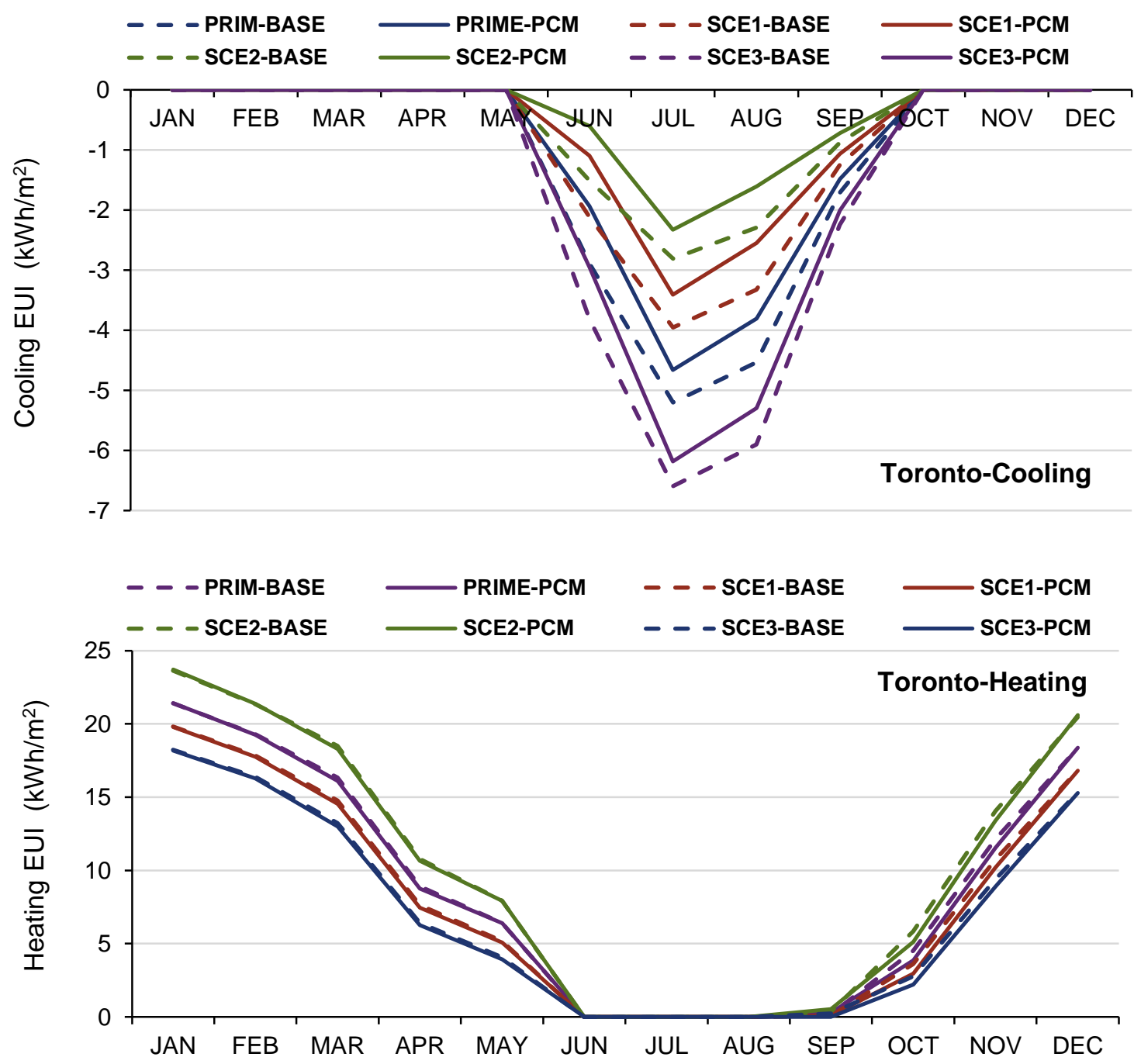

Figure 4.22. Monthly energy use in Toronto Units (Variable set point temperatures)

By observing changes in energy use in Toronto units a significant change is observed in cooling and heating loads in both baseline and PCM integrated units when temperature set points are changed. Pertaining to the results of energy use variation in Toronto units in Fig. 4.22, a better 
cooling energy performance is observed when the cooling set points are increased compared to the primary set points, i.e. scenarios 1 and 2 . This increase in set point temperatures entails a lower cooling demand as temperatures rise to $25^{\circ} \mathrm{C}$ or $26^{\circ} \mathrm{C}$ in scenario 2 .

Examining comfort in July on a monthly and daily basis shows contrasting results between energy use and thermal comfort. In terms of overheating in both baseline and PCM integrated units when cooling set points are increased from the primary scenario to $25^{\circ} \mathrm{C}$ and $26{ }^{\circ} \mathrm{C}$ in scenario 1 and 2, chances of overheating also rise significantly. However, changing the cooling set point to $23^{\circ} \mathrm{C}$ in scenario 3 , eliminates the rise of operative temperatures above $26^{\circ} \mathrm{C}$ completely, while it entails considerably higher cooling loads.

In the heating season in Toronto units, lowering heating set points linearly decreases the need for heating energy as shown in Fig. 4.22 in scenarios 1 and 3 with heating set points of $21^{\circ} \mathrm{C}$ and $20^{\circ} \mathrm{C}$. Comparable to the cooling season, energy performance and thermal comfort changes do not match as decreasing heating set points increases the number of hours with operative temperatures below $21^{\circ} \mathrm{C}$, shown in Table 4.10 for October and February.

By comparing cooling and heating energy use with indoor temperatures variations in summer and winter in Toronto units, it is evident that adopting scenario 1 or the primary set points previously used show acceptable results. Comparing the rate of change in PCM integrated units, using scenario 1 set points leads to a higher percentage of energy saving compared to the primary set point scenario. For instance, the highest cooling energy saving that occurs in June is $48.3 \%$ using scenario 1 , while using primary set points, the percentage of savings is $33.2 \%$. Similarly, in heating and shoulder seasons like October, the rate of energy saving in PCM integrated unit is $3.4 \%$ higher when scenario 1 set points are adopted

Table 4.10. Peak temperature variations by changing set point options- Toronto Units

\begin{tabular}{|l|r|r|r|}
\hline \multicolumn{4}{|c|}{ Number of hours for $\mathbf{T}_{\mathrm{OP}}>\mathbf{2 6} \mathbf{~}^{\circ} \mathbf{C}$ - July } \\
\hline $\begin{array}{l}\text { Set point } \\
\text { Scenario/Unit }\end{array}$ & $\begin{array}{l}\text { Baseline } \\
\text { Unit }\end{array}$ & $\begin{array}{c}\text { PCM } \\
\text { integrated } \\
\text { Unit }\end{array}$ & Difference \\
\hline PRIME & 74 & 56 & 18 \\
\hline SCE1 & 268 & 242 & 26 \\
\hline SCE2 & 407 & 439 & -32 \\
\hline SCE3 & 0 & 0 & 0 \\
\hline
\end{tabular}

\begin{tabular}{|l|r|r|r|l|r|r|r|}
\hline \multicolumn{4}{|c|}{ Number of hours for Top< $\mathbf{2 1}^{\circ} \mathbf{C}-$ October } & \multicolumn{3}{c|}{ Number of hours for Top< $\mathbf{2 1}^{\circ} \mathbf{C}$ - February } \\
\hline $\begin{array}{l}\text { Set point } \\
\text { scenario }\end{array}$ & $\begin{array}{c}\text { Baseline } \\
\text { Unit }\end{array}$ & $\begin{array}{c}\text { PCM } \\
\text { integrated } \\
\text { Unit }\end{array}$ & Difference & $\begin{array}{l}\text { Set point } \\
\text { scenario }\end{array}$ & $\begin{array}{c}\text { Baseline } \\
\text { Unit }\end{array}$ & $\begin{array}{c}\text { PCM } \\
\text { integrated } \\
\text { Unit }\end{array}$ & Difference \\
\hline PRIME & 88 & 56 & 32 & PRIME & 359 & 355 & 4 \\
\hline SCE1 & 202 & 118 & 84 & SCE1 & 517 & 525 & -8 \\
\hline SCE2 & 39 & 8 & 31 & SCE2 & 158 & 139 & 19 \\
\hline SCE3 & 327 & 277 & 50 & SCE3 & 585 & 617 & -32 \\
\hline
\end{tabular}


Performing the same analysis in heating and cooling seasons in Vancouver units a similar behavior is observed for cooling energy decrease when cooling set points are increased in scenario 1 and 2. The rate of change and peak cooling energy differs considerably from the primary scenario, as in scenario 1 and 2, cooling is minimal in summer months and the peak energy is shifted to September. When the cooling set point is decreased to $23^{\circ} \mathrm{C}$ cooling energy loads are increased, specifically, peak cooling energy in the month of August reaches to 186.4 $\mathrm{kWh} / \mathrm{m}^{2}$ in the baseline unit. Overall cooling EUI for one year in the primary scenario is 6.4 $\mathrm{kWh} \cdot \mathrm{m}^{2}$ in the baseline unit while using scenario 3 - set point of $23^{\circ} \mathrm{C}$ - the annual cooling EUI of the same unit is $10 \mathrm{kWh} / \mathrm{m}^{2}$.

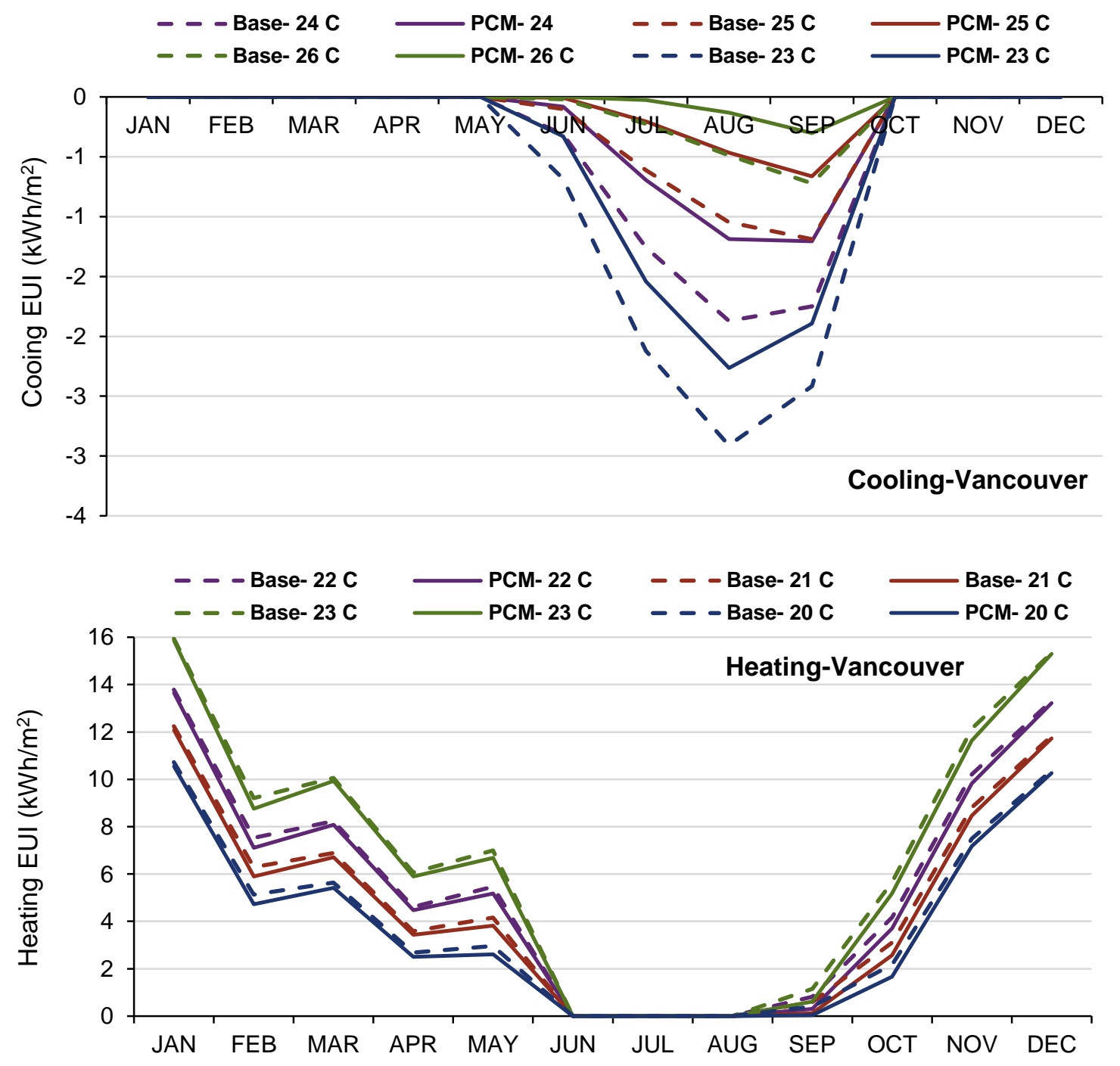

Figure 4.23. Monthly energy use in Vancouver (Variable set point temperatures)

The rate of change in the PCM integrated unit in annual cooling EUI is $38.1 \%$ for primary scenario and $24.7 \%$ when scenario 3 is adopted for the cooling set points. Furthermore, considering monthly cooling load in July, the impact of PCM in lowering cooling loads is $17 \%$ higher in the case of primary set points, which is a set point of $24^{\circ} \mathrm{C}$. Peak temperature 
variations show a complete elimination of overheating in both baseline and PCM integrated units when the cooling set point is $23^{\circ} \mathrm{C}$ (Scenario 3). Using a cooling set point of $24^{\circ} \mathrm{C}$ in the primary scenario also leads to only 2 hours of overheating on the baseline unit in July which is controlled by the PCM surfaces.

A regular pattern is observed for the heating season in Vancouver units as increasing the set point to $23^{\circ} \mathrm{C}$ leads to a higher heating load compared to the primary scenario which has a heating set point of $22^{\circ} \mathrm{C}$. As expected lowering set point to $20^{\circ} \mathrm{C}$ in winter results in 21.7 $\mathrm{kWh} / \mathrm{m}^{2}$ lower annual heating EUI compared to the primary scenario. However, observing the low peak operative temperatures below $21^{\circ} \mathrm{C}$, it is evident that lower heating set point of $20^{\circ} \mathrm{C}$ in scenario 3 entails increased low peak temperature values. Best result of reducing low peak temperatures is when heating set point is $23^{\circ} \mathrm{C}$ in scenario 2 . However, considering the rate of change in the PCM integrated unit, the primary scenario with set point of $22{ }^{\circ} \mathrm{C}$ shows a better PCM effectiveness in changing the operative temperatures.

Table 4.11. Peak temperature variations by changing set point options- Vancouver Units

\begin{tabular}{|l|r|r|r|}
\hline \multicolumn{4}{|c|}{ Number of hours for $\mathrm{T}_{\mathrm{OP}}>\mathbf{2 6 ^ { \circ } \mathbf { C }}$ - July } \\
\hline $\begin{array}{l}\text { Set point } \\
\text { scenario/Unit }\end{array}$ & $\begin{array}{l}\text { Baseline } \\
\text { Unit }\end{array}$ & $\begin{array}{c}\text { PCM } \\
\text { integrated } \\
\text { Unit }\end{array}$ & Difference \\
\hline PRIME & 2 & 0 & -2 \\
\hline SCE1 & 46 & 7 & -39 \\
\hline SCE2 & 112 & 24 & -88 \\
\hline SCE3 & 0 & 0 & 0 \\
\hline
\end{tabular}

\begin{tabular}{|l|r|r|r|l|r|r|r|}
\hline \multicolumn{4}{|c|}{ Number of hours for Top $\mathbf{2 1}^{\circ} \mathbf{C}-$ October } & \multicolumn{3}{c|}{ Number of hours for Top $\mathbf{2 1}^{\circ} \mathbf{C}-$ February } \\
\hline $\begin{array}{l}\text { Set point } \\
\text { scenario }\end{array}$ & $\begin{array}{c}\text { Baseline } \\
\text { Unit }\end{array}$ & $\begin{array}{c}\text { PCM } \\
\text { integrated } \\
\text { Unit }\end{array}$ & Difference & $\begin{array}{l}\text { Set point } \\
\text { scenario }\end{array}$ & $\begin{array}{c}\text { Baseline } \\
\text { Unit }\end{array}$ & $\begin{array}{c}\text { PCM } \\
\text { integrated } \\
\text { Unit }\end{array}$ & Difference \\
\hline PRIME & 151 & 80 & -71 & PRIME & 206 & 165 & -41 \\
\hline SCE1 & 307 & 234 & -73 & SCE1 & 370 & 326 & -44 \\
\hline SCE2 & 96 & 45 & -51 & SCE2 & 78 & 44 & -34 \\
\hline SCE3 & 398 & 335 & -63 & SCE3 & 484 & 503 & +19 \\
\hline
\end{tabular}

As the results show, a discrepancy exists between indoor temperature regulations and energy savings. However, in both Toronto and Vancouver units, primary scenario and scenario 1 show a balance in both indoor temperatures and energy changes in the PCM integrated units. Considering different outdoor weather patterns in heating and cooling season in each city, different patterns of PCM performance and set point selected could be explained.

Melting range of the Energain layer in the composite PCM system is from $18-22{ }^{\circ} \mathrm{C}$ which is mainly targeting the heating season. Therefore, selecting a higher main set point of 22 or $23^{\circ} \mathrm{C}$ ensures that this layer is melted and could function. If the heating set point is decreased, as in scenario 3 to $20^{\circ} \mathrm{C}$, even though overall heating loads are much lower in the baseline unit compared to other set point scenarios, the rate of change in the PCM integrated unit is much lower and in some instances, negative. This matter is specifically caused by the Energain PCM 
layer absorbing the heat produced by the heating system resulting in lower operative temperatures and higher need for heating generation to make up for the absorbed heat.

Another issue observed in hourly results in February is regarding system operation in set back temperatures during the day. In colder days, solar heat gain is not enough to heat the room even in the city of Vancouver with milder conditions, therefore the PCM is not melted during the day and the melting process starts at night when the system starts to run at main set point temperature. Instead of PCMs solidifying at night and releasing the heat back to the rooms, they are drawing the heat generated by the heating system in the PCM integrated unit. For instance, average daily outdoor weather in February in Toronto is $-5.7^{\circ} \mathrm{C}$, while in the same month in Vancouver average outdoor temperature is $5.1^{\circ} \mathrm{C}$.

The issue with the heating system operation and PCM activation mainly occurs on cold days such as February $1^{\text {st }}$ in which indoor operative temperatures are slightly lower in the PCM integrated unit from 12- 9 am. Mostly, at this period, the heating system is running at main set point temperature for instance $21^{\circ} \mathrm{C}$ considering scenario 1 . After this period, room operative temperatures reach $16.8^{\circ} \mathrm{C}$ and an increasing trend in operative temperatures of the PCM integrated units is observed. This factor indicates that Energain in PCM layer one is solidifying at this time and releasing the heat back to the room. As indoor temperatures reach $19{ }^{\circ} \mathrm{C}$ which is close to the melting threshold of $18^{\circ} \mathrm{C}$ for the Energain product, indoor operative temperatures in the PCM integrated units start to fall. This shows that the PCM is melting and storing the energy, while there is no excess heat in the space, heat produced by the heating system which runs on main set point at night is absorbed.

Late melting of the Energain PCM layer in early morning or before noon leads to slower heat storage in the composite PCM system and therefore lower operative temperatures. For instance, considering highest solar gains in $80 \%$ WWR units facing south after noon from 12 to $4 \mathrm{pm}$, higher indoor temperatures in the baseline unit results in elimination of heating in these periods with high temperatures of 23-25 C in February days. In contrast, in the PCM integrated units as the PCM starts to melt later in the day and continues to absorb heat from the room, the room temperatures at peak solar periods are not higher than the set point thus a negative energy use is observed indicating full load heating operation in the PCM integrated unit while the baseline unit needs no heating.

Opposite behavior in summer indicates that a set point of $24^{\circ} \mathrm{C}$ or the primary scenario is more effective in facilitating the partial solidification of the Bio PCM layer at night. Even though mechanical night ventilation is activated in the simulation model, indoor room temperatures are still high at night and do not allow for PCMs to fully solidify. However, with a set point of $24^{\circ} \mathrm{C}$, room and surface temperatures vary between 24-23 $\mathrm{C}$ at night which is in the freezing threshold of the Bio PCM. The results of this study are consistent with previous studies such as Kosny and Kossecka (2013), that demonstrated a higher PCM performance when indoor set point temperature is selected with a $1^{\circ} \mathrm{C}$ difference from the melting point of the PCM.

A comprehensive investigation on PCM performance is required on a surface level to analyze the relation of air temperature changes in the units to surface temperature changes. Particularly, composite PCM activation must be studied to better understand the relation of PCM melting point with indoor boundary conditions. Therefore, surface temperature variation in PCM integrated ceiling and a window facing wall are assessed when primary and scenario 1 set points are adopted in July and October. 

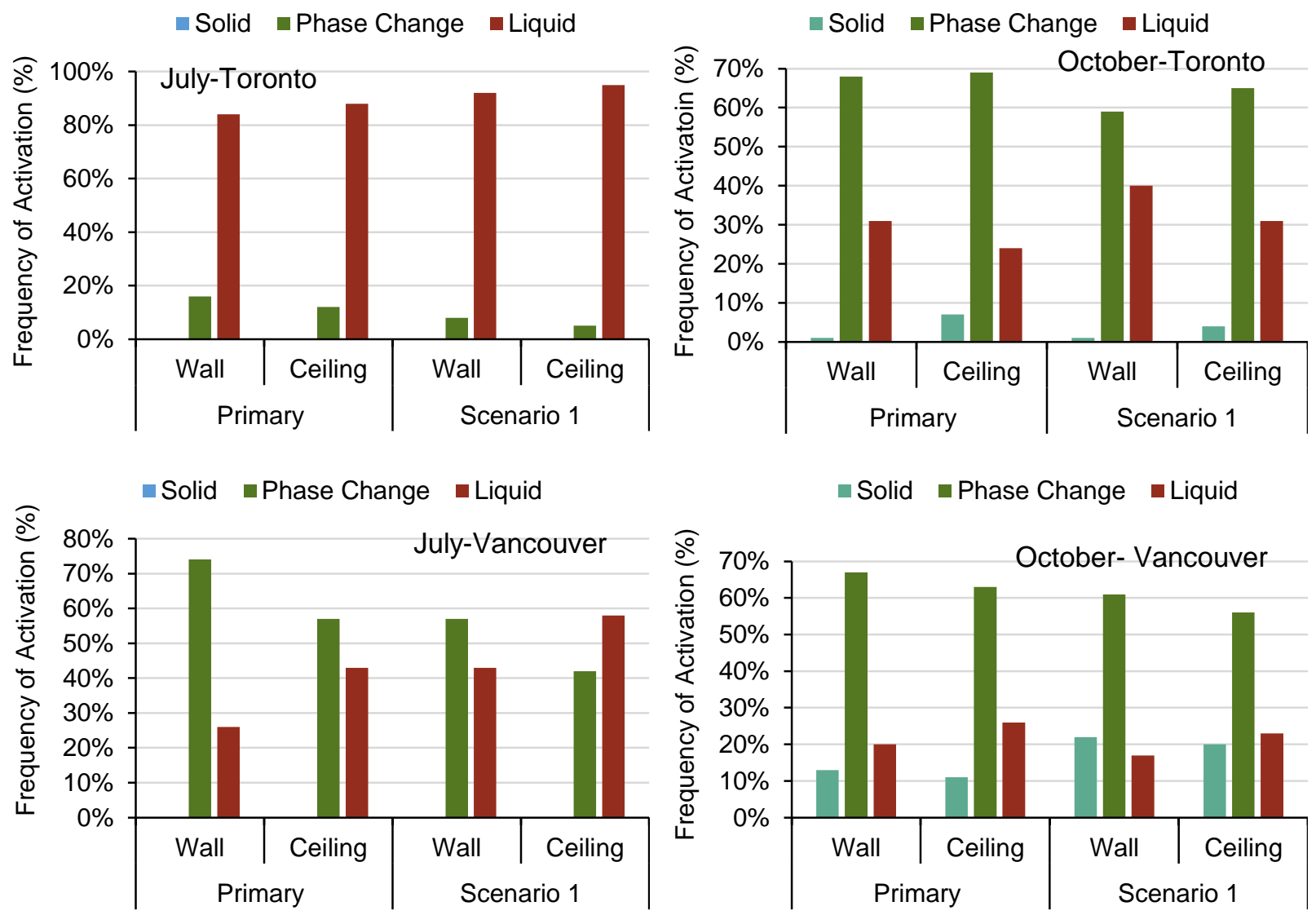

Figure 4.24. Frequency of activation based with variable set point

Results for frequency of activation in Fig. 4.24 show a higher percentage of activation in walls. An average $10 \%$ better activation is achieved when the primary set points are used in the Vancouver units. On average, considering the Bio PCM melting range, the PCM integrated PCM surfaces are active $65 \%$ of the time in the month of October in both cities. However, in July, a significantly higher rate of activation is experienced in PCM walls and ceilings in Vancouver as a result of milder conditions and higher chances of solidification.

\subsubsection{Study \#4: Amount of PCM}

In addition to the melting point, the amount of PCM is another important factor. Multiple studies have investigated the factor of PCM amount by changing the percentage of PCMs in the carrier material or thickness of PCM products. In this study, however, which is focused on a retrofit application, the main aim is to minimize additional thickness for an unobtrusive PCM application.

The study on PCM amount is done to assess the effectiveness of the composite PCM system as a function of mass, in other words how much PCM per surface area in the units could show the highest potential in energy saving. All the simulation tests so far have considered PCM integration to the entire ceiling surface area of the unit in addition to three main walls- two side walls and the window facing wall. Thus, no internal partitions have been designed in the units, and any PCM addition to the units is merely considered as an addition to interior partitions. 
The rate of change in annual energy consumption in relation to the amount of PCM per unit area is observed, this is to assess if a trend exists between PCM amount per area and energy saving. Based on the outcomes of previous tests, the case in which the composite PCM system had the highest impact on both energy and temperatures has been selected. Thus $80 \%$ WWR units facing south are tested here with the primary set points of $24^{\circ} \mathrm{C}$ in summer and $22{ }^{\circ} \mathrm{C}$ in winter. The amount of PCM per surface area is described in detail in Table 4.12. The primary assumption in this study has been the addition of the composite PCM system to all the surfaces which results in an overall value of $13.5 \mathrm{Kg} / \mathrm{m}^{2}$, which is a ratio of total weight of the applied PCMs to the total unit area of $63.7 \mathrm{~m}^{2}$. On this trend, several other ratios have been simulated in both Vancouver and Toronto units. Table 4.12. shows the different cases assessed in this study.

It must be clarified that calculation of the composite PCM's weight as shown in Table 4.12, has been performed by considering the actual size of the panels used to form the composite PCM system. The values shown are considering a $100 \%$ coverage of surfaces as required for the simulation inputs. It is evident, however, that the total weight of this system in the primary case is too high, additionally, application of the panels to the entire surface of the walls and ceilings is not practically feasible. Particularly in the ceiling where ductwork and other obstructions above ceiling tiles would reduce the space for PCMs. The intent is to find a correlation or trend by comparing PCM per area to adjust the amount of PCMs in the space that could be feasible to apply in real situation.

As this study considers commercial panel products, increasing or decreasing their amount simply refers to adding or removing panels integrated to surfaces. Partial application of PCM panels to a surface could not be accurately adjusted in the simulation model, thus to reduce the amount of PCMs in the model, an entire wall or ceiling was removed in different cases to assess the rate of change. For instance, as outlined in Table 4.14, in option 3, the PCM is only considered on the three main walls and in option 2, PCM is only applied to the ceiling.

Table 4.12. PCM amount option in the PCM integrated units

\begin{tabular}{|l|l|l|c|c|c|c|c|c|c|}
\hline Options & Primary & $\begin{array}{c}\text { Option } \\
\mathbf{1}\end{array}$ & $\begin{array}{c}\text { Option } \\
\mathbf{2}\end{array}$ & $\begin{array}{c}\text { Option } \\
\mathbf{3}\end{array}$ & $\begin{array}{c}\text { Option } \\
\mathbf{4}\end{array}$ & $\begin{array}{l}\text { Option } \\
\mathbf{5}\end{array}$ & $\begin{array}{l}\text { Option } \\
\mathbf{6}\end{array}$ & $\begin{array}{l}\text { Option } \\
\mathbf{7}\end{array}$ & $\begin{array}{l}\text { Option } \\
\mathbf{8}\end{array}$ \\
\hline $\begin{array}{l}\text { Surfaces } \\
\text { with PCM } \\
\text { integration }\end{array}$ & $\begin{array}{l}-3 \text { main } \\
\text { Walls } \\
- \text { Ceiling }\end{array}$ & $\begin{array}{l}2 \text { side } \\
\text { walls }\end{array}$ & Ceiling & $\begin{array}{l}3 \text { Main } \\
\text { walls }\end{array}$ & $\begin{array}{l}-1 \text { side } \\
\text { wall } \\
- \text {-Ceiling }\end{array}$ & $\begin{array}{l}-3 \text { main } \\
\text { walls } \\
-2 \\
\text { partition }\end{array}$ & $\begin{array}{l}-3 \text { main } \\
\text { walls } \\
- \text {-Ceiling } \\
-1 \\
\text { partition } \\
(7.5 \mathrm{~m})\end{array}$ & $\begin{array}{l}-3 \text { main } \\
\text { walls } \\
- \text { - Ceiling } \\
-1 \\
\text { partition } \\
(8.5 \mathrm{~m})\end{array}$ & $\begin{array}{l}-3 \text { main } \\
\text { walls } \\
- \text { Ceiling } \\
-2 \\
\text { partition }\end{array}$ \\
\hline $\begin{array}{l}\text { Composite } \\
\text { PCM per } \\
\text { unit area } \\
\left(\mathrm{Kg} / \mathrm{m}^{2}\right)\end{array}$ & 13.5 & 4.7 & 6.6 & 6.9 & 8.9 & 11.1 & 15.7 & 15.90 & 17.7 \\
\hline
\end{tabular}

The results in Fig. 4.25 show a non-regular pattern as the amount of PCM integrated per unit area is changed. However, by observing the rate of change in cooling energy in the PCM integrated unit, increasing the total mass per area as in options 6, 7 and 8 results in nearly $75 \%$ reduction of total annual cooling energy demands. This increase is also observed in overall annual energy and heating energy savings of more than $6 \%$ in these scenarios. A distinct behavior is observed in option 8 with a PCM mass per area of $11.1 \mathrm{Kg} / \mathrm{m}^{2}$. Even though this 
ratio is smaller than the last three options in the graph as well as the primary option, the overall results show a high annual heating and cooling energy saving potential for this option. It is inferred from the results that positioning the PCM within the units in relation to solar gain availability could have a much higher influence on PCM effectiveness compared to changing of the PCM mass per area. For instance, comparing option 2 to option 3 shows significantly lower energy saving in option 2 when the PCMs are only applied to the ceiling with a higher mass to area ratio. Similarly, comparison of options 3 and 4 shows similar results, as applying PCMs to all the walls with $6.9 \mathrm{Kg} / \mathrm{m}^{2}$ shows more cooling and heating savings compared to option 4 with $8.9 \mathrm{Kg} / \mathrm{m}^{2}$ mass to area ratio.

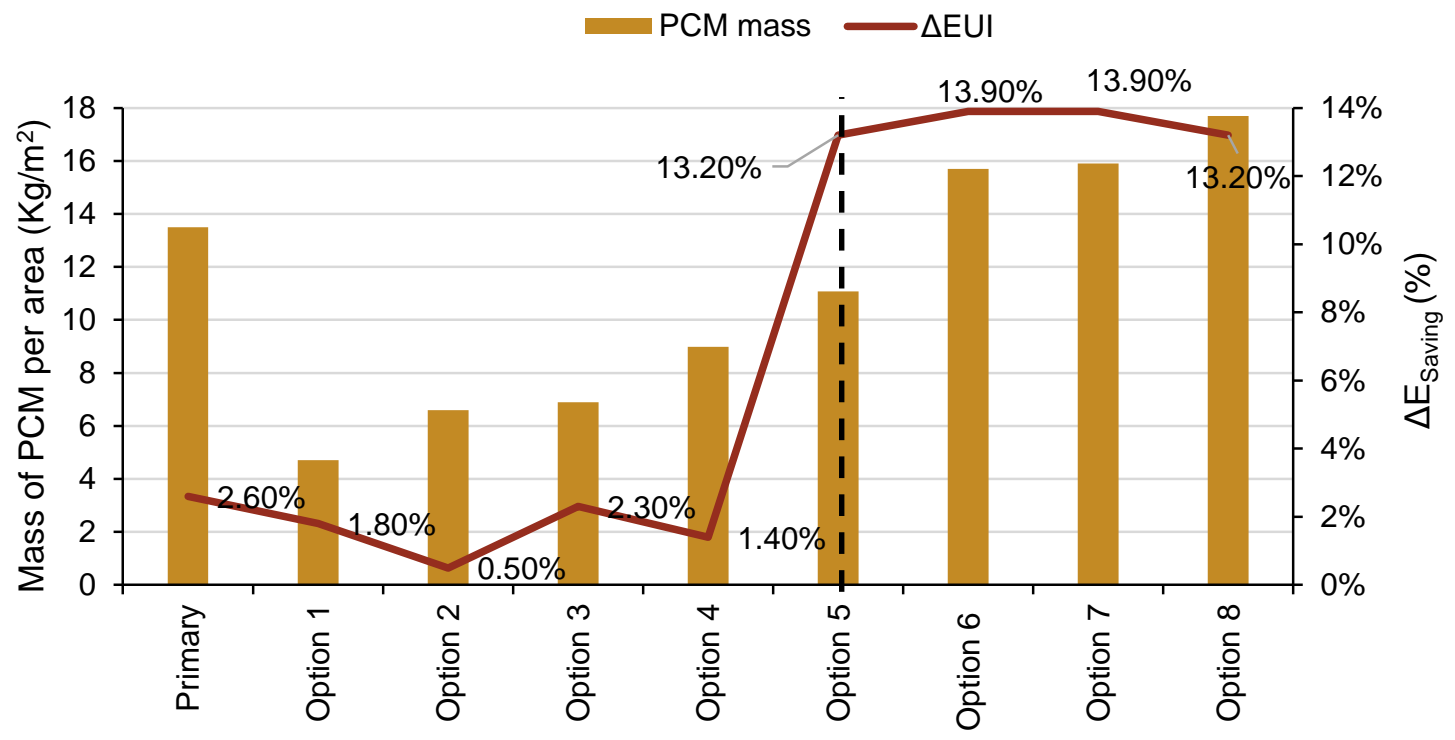

a) Toronto

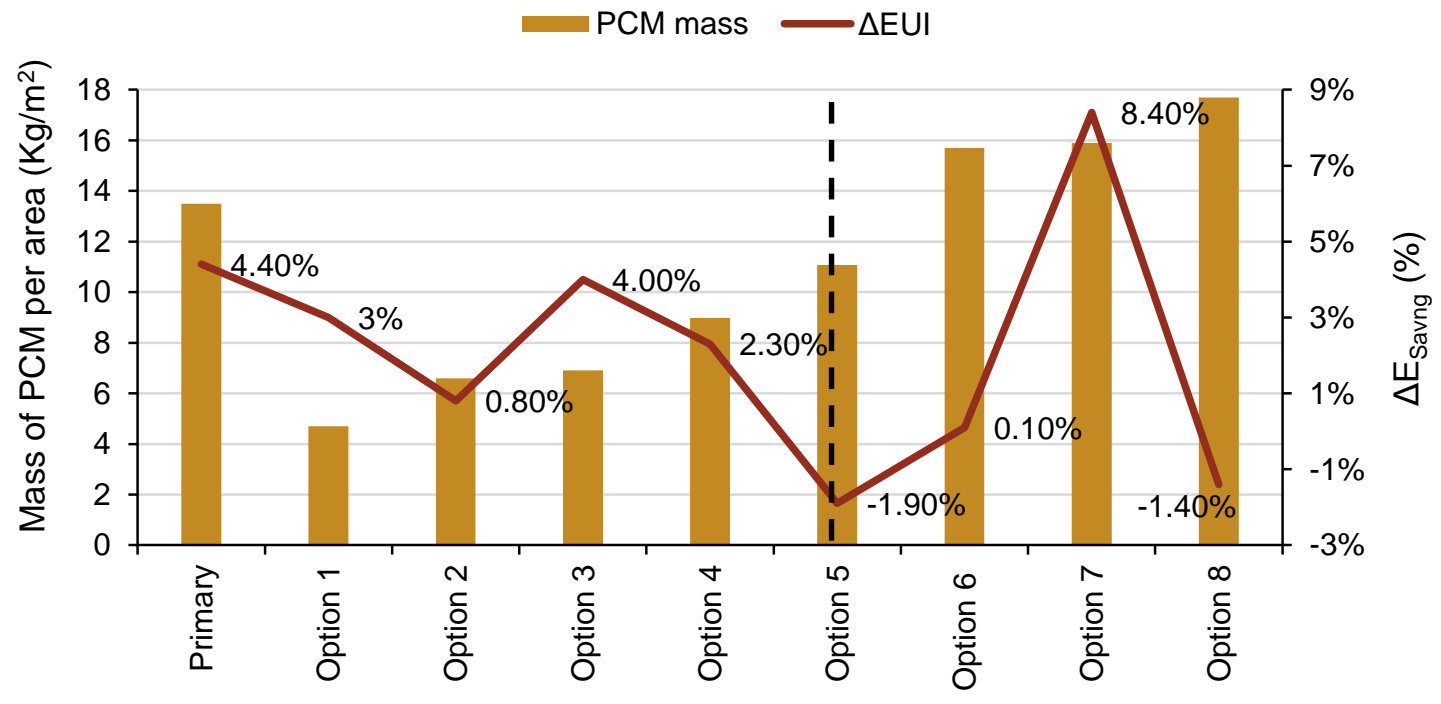

b) Vancouver

Figure 4.25. Correlation of PCM amount and percentage of annual EUI saving 
The percentage of change in Vancouver units with variable PCM mass shows a significantly different trend compared to Toronto units as the amount of PCMs are increased. Except for option 7, increasing the amount of PCM from the primary option results in very low and even negative energy saving in the PCM integrated unit. When the PCM system is integrated to a partition wall directly facing the window such as option 5 and option 6 , a negative rate of change in total heating energy loads as the amount of solar gain is blocked to back walls and ceiling surfaces. This shows a diminishing effect of the PCM even though the amount is increased. On the contrary, adding a partition in the middle of the unit parallel to the side walls as in option 7 results in the highest energy saving in Vancouver units in addition to main walls and ceiling. In fact, applying PCMs on this partition leads to $100 \%$ annual cooling reduction in Vancouver.

The amount of thermal inertia in mechanically cooled buildings depends on the amount of solar radiation to be activated. No optimal solution could be considered for the mass of the PCM based on the results of the simulation model. In the case of a clear trend, energy savings could be assessed by changing the number of panels applied to each surface to lower the mass and apply the PCM to more partition surfaces in the units. Since the weight of the proposed composite PCM system is quite high specifically in primary scenario and options 6,7 and 8, a more detailed analysis is required. A study concerning structural integrity of the units must be performed in addition to cost implications of these ratios compared to the amount of energy saving to justify and find an optimal solution based on PCM mass.

The final suggestion in regards to balancing PCM mass or thermal inertia with weight of the system is to use materials with higher latent heat values with less density. Changing latent heat values was not a variable in this study however the commercial products making the composite PCM system had very high latent heat value compared to other market available products. Certainly, other approaches in the field of mass to area ratio of PCMs and their impacts on energy and comfort would be useful.

\subsection{Overview}

The preliminary analysis was a necessary stage for the design and optimization of the PCM system through a correlation analysis. Bio PCM product used in layer 1 with a $\mathrm{T}_{\mathrm{mp}}$ of $25^{\circ} \mathrm{C}$ had a higher impact on energy use intensity and reduction of high peak temperatures in Toronto units during the summer. In Vancouver, both PCMs performed well, each showing better results in a different period. For instance, using Bio PCM with the melting point of $23^{\circ} \mathrm{C}$ in Vancouver units shows better results in reducing low peak temperatures and performs better in months with lower indoor room temperatures such as June. However, annual results indicate a better energy performance of Bio PCM $25^{\circ} \mathrm{C}$ similar to Toronto units, therefore this PCM was selected to form the composite PCM layer.

Considering compatibility of melting points and indoor temperatures, it was shown in study \#3

(Section 4.2.4) that the activation of surfaces and indoor temperature set points are related. Set point temperatures in $1-2^{\circ} \mathrm{C}$ range of difference from the melting point of the PCM provided the most optimal condition for the performance of the composite PCM system. It should be noted that the preliminary analysis was performed using the primary cooling set point of $24^{\circ} \mathrm{C}$ and set back temperature of $25^{\circ} \mathrm{C}$. This range is closer to the melting range of Bio PCM $25^{\circ} \mathrm{C}$, which could be an explanation for its better performance in the preliminary study. However, lower set points such as cooling set point of $23^{\circ} \mathrm{C}$ with set back of $24^{\circ} \mathrm{C}$ might correspond better with Bio 
PCM with $\mathrm{T}_{\mathrm{mp}}: 23^{\circ} \mathrm{C}$. Similar change in PCM activation could be conducted by changing the PCM product in layer 2 to have a matching melting point with the heating set point temperatures.

The main simulation tests focused on analyzing the dynamic behavior of the composite PCM system in relation to key influencing factors of indoor environment and solar gain changes. The intent of these tests was to monitor the behavior of the composite PCM system on a whole building scale in interaction with internal gains, occupants and mechanical system operation. First, the overall impact of PCM integrated surfaces on energy use and indoor temperatures is assessed in different scenarios. The second stage of the tests is to examine how the selected variables affect the performance range of the PCM system. The following results emerged from the simulation study:

- The highest energy saving and decrease in daily temperature swings in the PCM integrated unit is achieved in $80 \%$ WWR units;

- Annual energy savings are higher in the city of Vancouver, with the highest savings during the cooling season, while highest rate of savings in Toronto occurs in fall months;

- As solar gains and indoor temperatures are lower in baseline units with $40 \% \mathrm{WWRs}$, the composite PCM system has a lower chance of activation;

- The impact of shading on controlling indoor temperatures is evident by comparing heating and cooling seasons. In fall and winter, the position of the sun in the sky is lower, allowing some radiation to enter the rooms. In summer, the sun is higher in the sky and the shading blocks most of the incoming solar insolation;

- Summer night temperatures show that indoor room and surface temperatures hardly go below the melting threshold of Bio PCM layer. Future research by considering higher mechanical ventilation flow rates might be an appropriate method to decrease temperatures and facilitate full PCM solidification;

- No single linear relation could be formed between PCM activation and solar gain alone, as ambient climate and indoor boundary conditions are the primary influencing factors on PCM activation;

- The Increase of energy use in PCM integrated units in the heating season occurs mostly in highly glazed units. This leads to melting process starting at colder periods during the night while the heating system is in operation that leads to storage of HVAC generated heat by the PCM resulting in more heating loads to compensate for the lost heat;

- Increasing mass of the composite PCM- per unit does not follow a linear trend of increase in energy savings. It was shown that addition of PCMs to the walls is more beneficial to the addition of PCMs solely to the ceiling. 


\section{Solar gain and PCM performance through WWR and orientation changes:}

By comparing solar gain rates and energy use, a direct link could be seen between the amount of solar radiation in each month and the need for energy. As glazing ratios get smaller, the impact of solar gain on overall energy use and indoor temperature variation is also changed pointing to the higher influence of boundary conditions on PCM performance in units with lower WWR. However, $60 \%$ units in all different months of the analysis showed a moderate rate of change when composite PCM was applied.

The inclusion of the composite PCM system shows better results in highly glazed units in both heating and cooling seasons due to higher PCM activation. Glazed facades entail higher vulnerability to ambient weather conditions and create a space susceptible to large solar gain and heat loss. The surface temperature range in higher glazed buildings is closer to the melting range of the composite PCM system. In Vancouver, similar pattern to Toronto is observed however milder temperatures and solar gains, removes the chance of extreme temperature thus much higher impacts are observed. In fact, the composite PCM system has a higher chance of undergoing a full phase change cycle in Vancouver without the need for additional night cooling in Vancouver. Conversely high summer temperatures in Toronto might lead to PCMs staying melted for a few days if no night cooling is provided.

The amount of solar gain in units is more significant in fall and winter seasons which helps to passively heat the building, while in summer due to existence of balcony shading, extreme solar gain penetration to units is mitigated. As discussed in energy analysis, energy use reduction is resulted mainly by peak load reduction and elimination of energy use due to passive heating or cooling in the PCM integrated units. While this is consistent with previous studies in this field, energy saving due to peak load shifting was not a strong outcome in this study.

Since there was a discrepancy between thermal comfort and energy analysis, it is assumed that by modifying the schedules of the HVAC system with time of solar gain and PCM melting point this factor would be eliminated. Additionally, changing the set back temperature closer to the main set point temperatures might show better results in temperature regulation and ultimately energy saving. For instance, reducing set back temperature to match the set point temperature, increases the overall rate of cooling energy use, however, it could potentially reduce overall cooling loads but could result in lower average temperatures. Furthermore, addition of PCMs could prolong a stable temperature range to eliminate or reduce the peak energy loads. In winter, however, one of the main problems observed in the results was lack of PCM melting during the day in winter even though solar gain is quite high in units with high WWR. This is mainly due to low set back temperature of $18^{\circ} \mathrm{C}$ which allows the room and surface temperatures to decrease considerably.

While lack of melting is a serious problem for PCM surfaces in winter, lack of solidification is another issue in the cooling season. Initially, night cooling using mechanical ventilation was used in the simulation models which did not show a notable improvement in solidifying the PCMs. Testing night mechanical cooling by increasing the rate could potentially increase the rate of PCM solidification in summer. In previous studies, it is guaranteed that higher flow rates at night could prepare PCM products for their next cycle. Ultimately, natural ventilation could be another option to facilitate night cooling, however, this factor was not analyzed in this study due 
to constraints of high-rise apartments in accommodating natural ventilation and assumption of occupant driven behavior as an inaccurate measure for PCM activation.

\section{Shortcomings of the simulation study}

The simulation study proved to be an appropriate method for a comprehensive parametric analysis in this study, however, detailed investigation of the PCM layers is not possible through the simulation analysis. Only the surface temperature data are provided using the simulation models which represents the gypsum board panels facing the room. Thus, it is necessary to investigate temperature and heat flow distribution through both layers of the composite PCM system in relation to room temperature variations.

Further limitations of the simulation study are:

- Inability of the software to calculate PCM hysteresis which prevents an accurate quantification of PCM activation;

- Uncertainty for the calculation of a hybrid PCM system in the software, particularly considering the second layer of PCM;

- Nominal data inputs in the simulation model provided by data sheets may not represent the full potential of the PCM products used

In conclusion, the analytical results of the simulation study prove the potential and effectiveness of the composite PCM system and successfully show the extreme dynamism and sensitive relation of PCM performance with the investigated variables. 


\section{Chapter 5 : Experimental Study}

To address the shortcomings of the simulation model in assessing the performance of the composite PCM system in detail, conducing an experimental test is required. The aim of field tests is to analyze the behavior of the composite PCM system in detail to better understand their daily activation, in addition to observing the technical feasibility of the proposed system. Small scale test cells provide more flexibility for field experiments as they could easily be modified.

The experimental tests rely on passive solar gain and ambient temperatures to activate the composite PCM system as no mechanical interventions are used. The objective of this research is to monitor the behavior of the composite PCM application for four months. Including seasonal temperature variations allows for a more comprehensive analysis of how the composite PCM system performs.

\subsection{Experimental tests methodology}

Two small scale test cells were constructed, one reference cell as a baseline and the second cell with PCM-enhanced walls and ceiling. As illustrated in Figure 5.1, the test cells have length, width and height of $70 \times 60 \times 40 \mathrm{~cm}$ which replicates an apartment unit on a smaller scale of 1:10. The test cells have one glazed wall which covers $80 \%$ of the façade indicating highly glazed apartment units. Furthermore, higher glazing ratio allows for testing of the composite PCM system under larger solar gain and temperature swings.
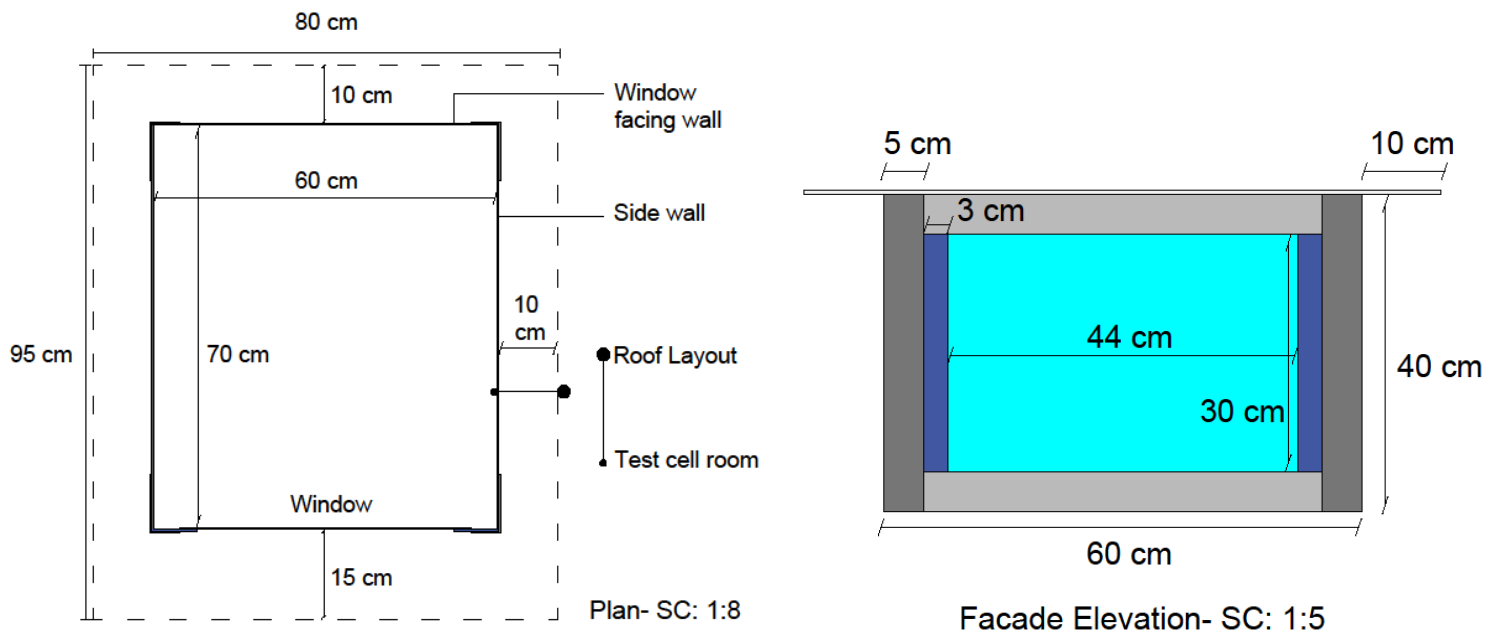

Figure 5.1- Plan and Front elevation of a constructed test cell

Test cells were constructed with an aluminum structural frame, using $3 \mathrm{~mm}$ solid aluminum Lshaped channels. This type of structure provides flexibility to add or remove enclosure materials or to modify the thickness of the used materials. The structural frames were connected using nuts and bolts for easier installation and future modifications. The outer shell of the test cell is covered with rigid white polyethylene plastic sheets with $0.5 \mathrm{~cm}$ thickness. The white color is selected for exterior surfaces to maximize reflection. $2 \mathrm{~cm}$ of water resistant plywood sheets (Form Ply) were positioned on the ceiling and the floor of both test cells. To insulate the units, 
extruded polystyrene (XPS) insulation with an RSI value of $0.88 \mathrm{~W} / \mathrm{m} . \mathrm{K}$ per $25 \mathrm{~mm}$ was used on all the walls, floor and ceiling surfaces. For the glazing, a single $3 \mathrm{~mm}$ clear glass pane was installed on the façade of the cells.
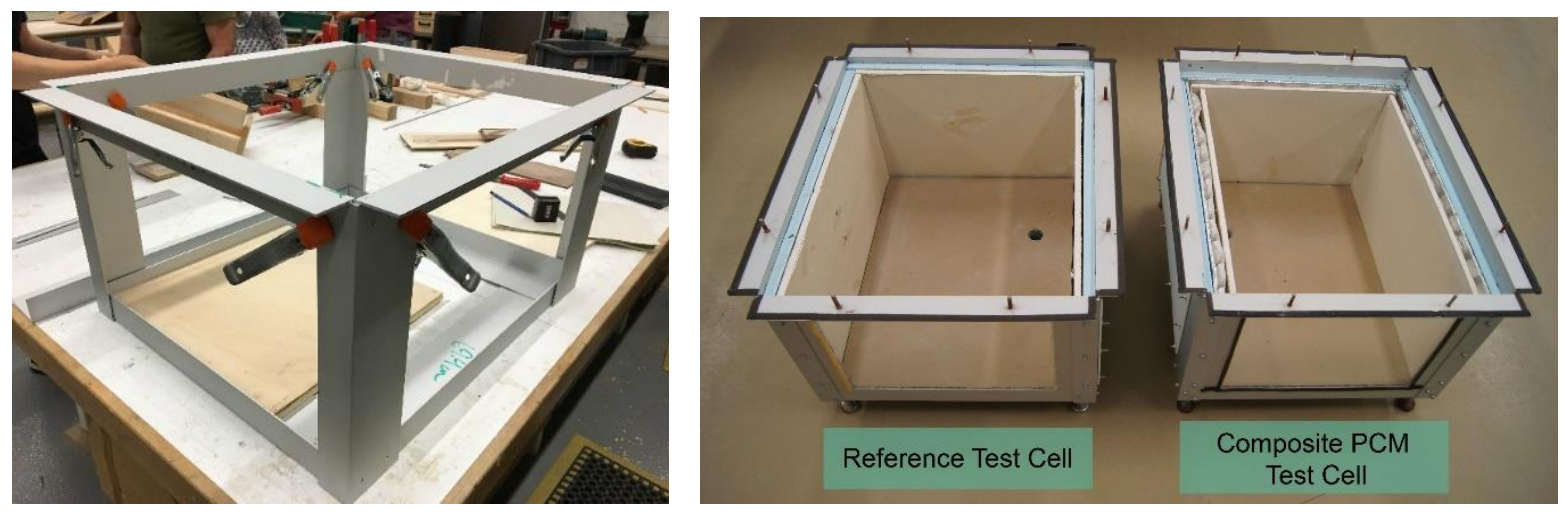

Figure 5.2- Aluminum structural frame of the test cells

The roof construction is similar to the walls, however, the exterior surface of the roofs is extended on all four sides and includes a $15 \mathrm{~cm}$ extruded shading over the window. The material used for the exterior roof surfaces is also the white polyethylene plastic sheets, with drip edges and a slight slope to direct the rain water away from the cells. Figure 5.3, shows finished test cells on the test site facing different orientations.
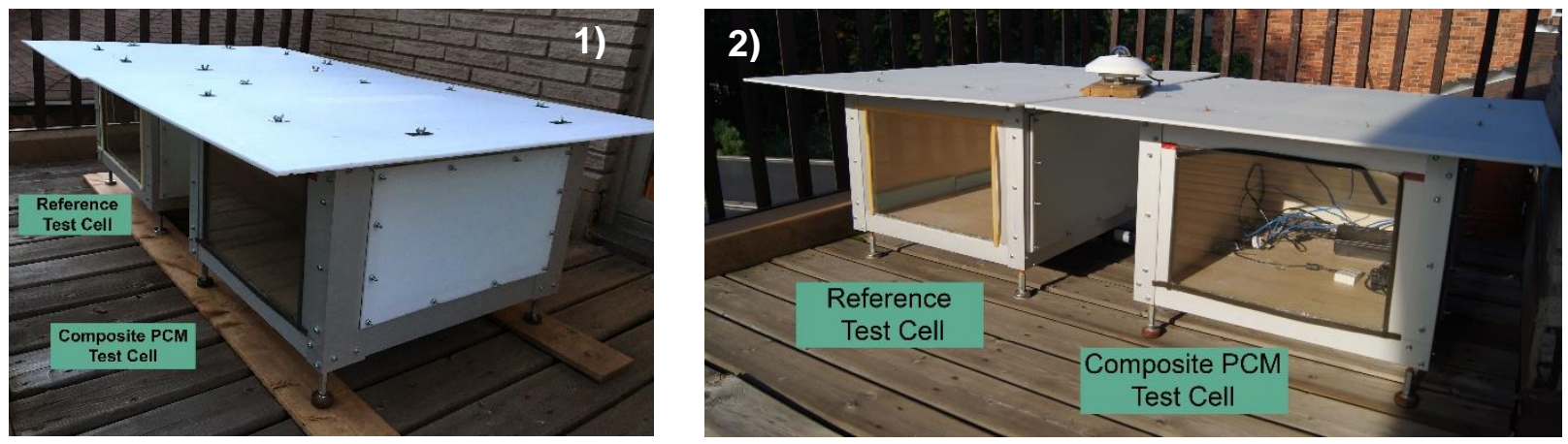

Figure 5.3. 1) Test cells facing south - 2) Test cells facing east

The main enclosure assembly includes gypsum boards facing the interior spaces on all walls and ceiling surfaces, with XPS insulation located behind it. The PCM boards are integrated into this assembly between the gypsum board and the XPS insulation. The composite PCM system is applied to three walls and the ceiling of the composite PCM test cell. The arrangement of the PCM boards in the composite PCM wall and ceiling is detailed in Figure 5.4. For simplification, the test cell integrated with PCMs is referred to as the "Composite PCM test cell" and the test cell without PCM application as the "Reference test cell". 


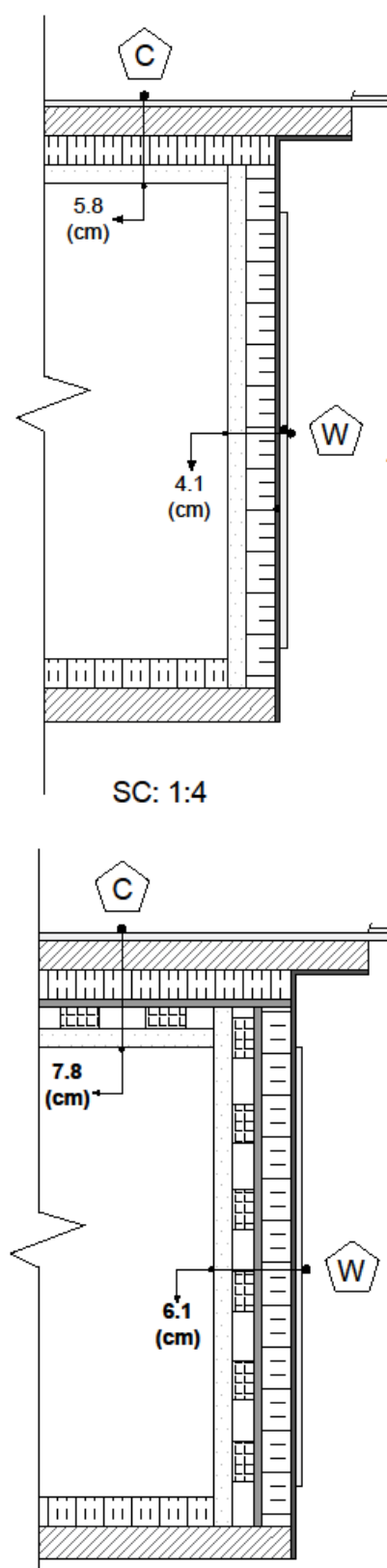

SC: $1: 4$

\section{$15 \mathrm{~cm}$}

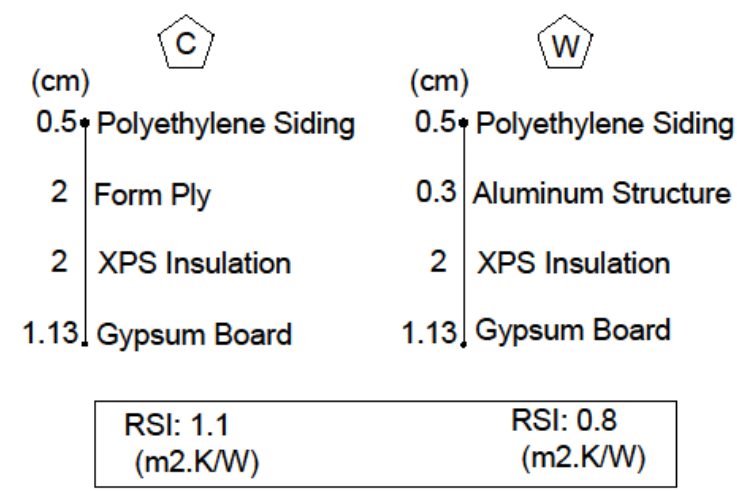

Reference Test Cell
$15 \mathrm{~cm}$

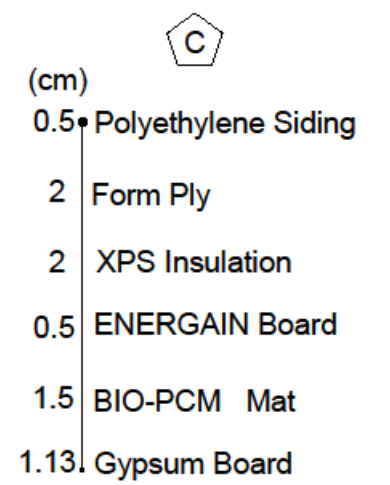

(cm)

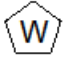

0.5 Polyethylene Siding

0.3 Aluminum Structure

2 XPS Insulation

0.5 ENERGAIN Board

1.5 BIO-PCM Mat

1.13. Gypsum Board

Figure 5.4. Enclosure composition in reference test cell

Table 5.1 summarizes physical and thermal properties of the enclosure assembly in each layer. Comparing the thermal resistance of reference and PCM integrated surfaces a slight increase could be seen in the overall RSI value by the inclusion of the PCM products. The RSI value of the reference wall is $0.8 \mathrm{~m}^{2} . \mathrm{K} / \mathrm{W}$, while the composite $\mathrm{PCM}$ wall has a thermal resistance of 0.9 $\mathrm{m}^{2}$.K/W. Considering an additional layer of Form Ply in the ceiling, the RSI value of reference ceiling is 0.9 , and $1.1 \mathrm{~m}^{2} . \mathrm{K} / \mathrm{W}$ in the composite PCM ceiling. This increase in thermal resistance by using PCM products is observed in previous studies such as Kuznik and Virgone (2009a) and Muruganantham et al. (2010). 
Table 5.1. Properties of materials used in the test cell enclosure

\begin{tabular}{|l|c|c|c|c|c|}
\hline Components & $\begin{array}{c}\text { Thickness } \\
(\mathbf{c m})\end{array}$ & $\begin{array}{c}\text { Thermal } \\
\text { Conductivity } \\
(\mathbf{W} / \mathbf{m} . \mathbf{k})\end{array}$ & $\begin{array}{c}\text { Area } \\
\text { Weight } \\
\left(\mathbf{K g} / \mathbf{m}^{2}\right)\end{array}$ & $\begin{array}{c}\text { Specific } \\
\text { Heat } \\
(\mathbf{K J / K g} . \mathbf{K})\end{array}$ & $\begin{array}{c}\text { Latent } \\
\text { Heat } \\
(\mathbf{K J} / \mathbf{K g})\end{array}$ \\
\hline Gypsum board & 1.1 & 0.16 & 7.8 & 0.9 & - \\
\hline Bio PCM & 1.5 & 0.20 & 2.7 & 2.1 & 200 \\
\hline Energain board & 0.5 & $0.18-0.14$ & 4.5 & 2.5 & 70 \\
\hline XPS Insulation & 2.0 & 0.03 & 1.5 & 1.5 & - \\
\hline
\end{tabular}

Considering different dimensions for the window facing wall, the side walls, and the ceiling as shown in the plan drawings, the amount of PCM applied to each surface also varies. Table 5.2 shows the amount of PCM and the dimension of the PCM products applied on each surface in the composite PCM test cell. The total amount of Energain PCM is higher on all the surfaces in the cell. Considering all three walls, more PCMs are positioned on the vertical surfaces compared to the ceiling. Total surface to volume ratio is 11.3 in the reference cell and 12.6 in the composite PCM test cell.

Table 5.2. Weight of PCM panles on each surface in the composite PCM cell

\begin{tabular}{|l|c|c|c|c|c|c|}
\hline \multirow{2}{*}{ Physical properties } & \multicolumn{2}{|c|}{ Window facing wall } & \multicolumn{2}{c|}{ Side walls } & \multicolumn{2}{c|}{ Ceiling } \\
\cline { 2 - 7 } & Bio PCM & Energain & Bio PCM & Energain & Bio PCM & Energain \\
\hline Dimensions (cm) & $53 \times 33$ & $54.5 \times 34.5$ & $59 \times 33$ & $65 \times 34.5$ & $63 \times 46.5$ & $69 \times 58.5$ \\
\hline $\begin{array}{l}\text { Measured Weight } \\
\text { of PCM panels (Kg) }\end{array}$ & 0.7 & 1 & 0.7 & 1.2 & 1.32 & 1.82 \\
\hline $\begin{array}{l}\text { *PCM per weight of } \\
\text { the surface (Kg) }\end{array}$ & $\begin{array}{c}0.7 / 2.9= \\
0.24 \mathrm{Kg}\end{array}$ & $\begin{array}{c}1 / 2.9= \\
0.34 \mathrm{Kg}\end{array}$ & $\begin{array}{c}0.7 / 3.4= \\
0.21 \mathrm{Kg}\end{array}$ & $\begin{array}{c}1.2 / 3.4= \\
0.35 \mathrm{Kg}\end{array}$ & $\begin{array}{l}1 / 5.4= \\
0.18 \mathrm{Kg}\end{array}$ & $\begin{array}{c}0 / 5.4= \\
0.37 \mathrm{Kg}\end{array}$ \\
\hline
\end{tabular}

Test cells were positioned on the site with access to three orientations of south, east, and west. The test site is in the city of Hamilton, Ontario $\left(43.2^{\circ} \mathrm{N}, 79.8^{\circ} \mathrm{W}\right)$, located in ASHRAE zone 6 , with 267 cooling degree days and 3896 heating degree days. This location is primarily selected for the proximity of its weather conditions to the city of Toronto and variations between summer and fall month temperatures to observe the change. To examine the performance of the two selected PCM products in more detail, performing the tests over several weeks is more appropriate than previous similar studies covering shorter periods. Thus, tests are conducted from July to October 2016. Table 5.3 shows the historical climate data in Hamilton in the past 20 years in the targeted four months

Table 5.3. Climate data for Hamilton, 20-year average values (Government of Canada, 2016)

\begin{tabular}{|l|c|c|c|}
\hline \multicolumn{1}{|c|}{ Month } & Max & Min & Mean \\
\hline July & $26.5^{\circ} \mathrm{C}$ & $14.7^{\circ} \mathrm{C}$ & $20.6^{\circ} \mathrm{C}$ \\
\hline August & $25.6^{\circ} \mathrm{C}$ & $14.6^{\circ} \mathrm{C}$ & $20.1^{\circ} \mathrm{C}$ \\
\hline September & $21.3^{\circ} \mathrm{C}$ & $10.6^{\circ} \mathrm{C}$ & $16^{\circ} \mathrm{C}$ \\
\hline October & $14.4^{\circ} \mathrm{C}$ & $4.6^{\circ} \mathrm{C}$ & $9.5^{\circ} \mathrm{C}$ \\
\hline
\end{tabular}



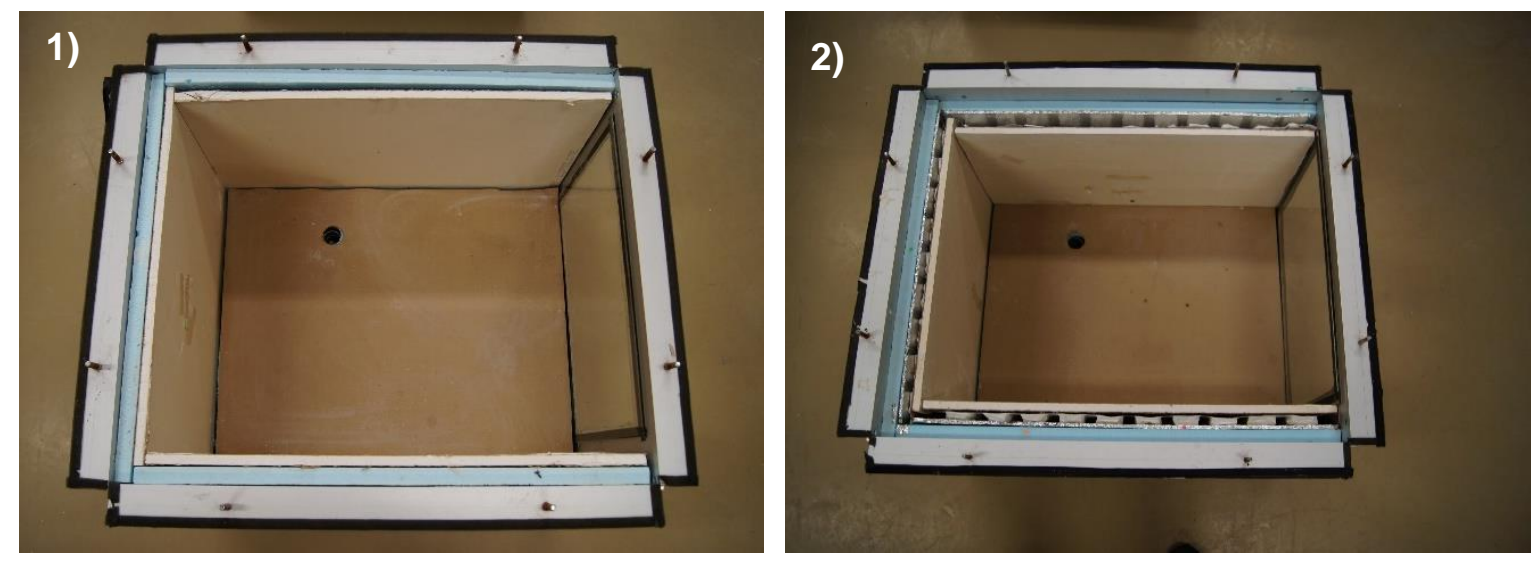

Figure 5.5. 1) Composite PCM cell - 2) Reference cell
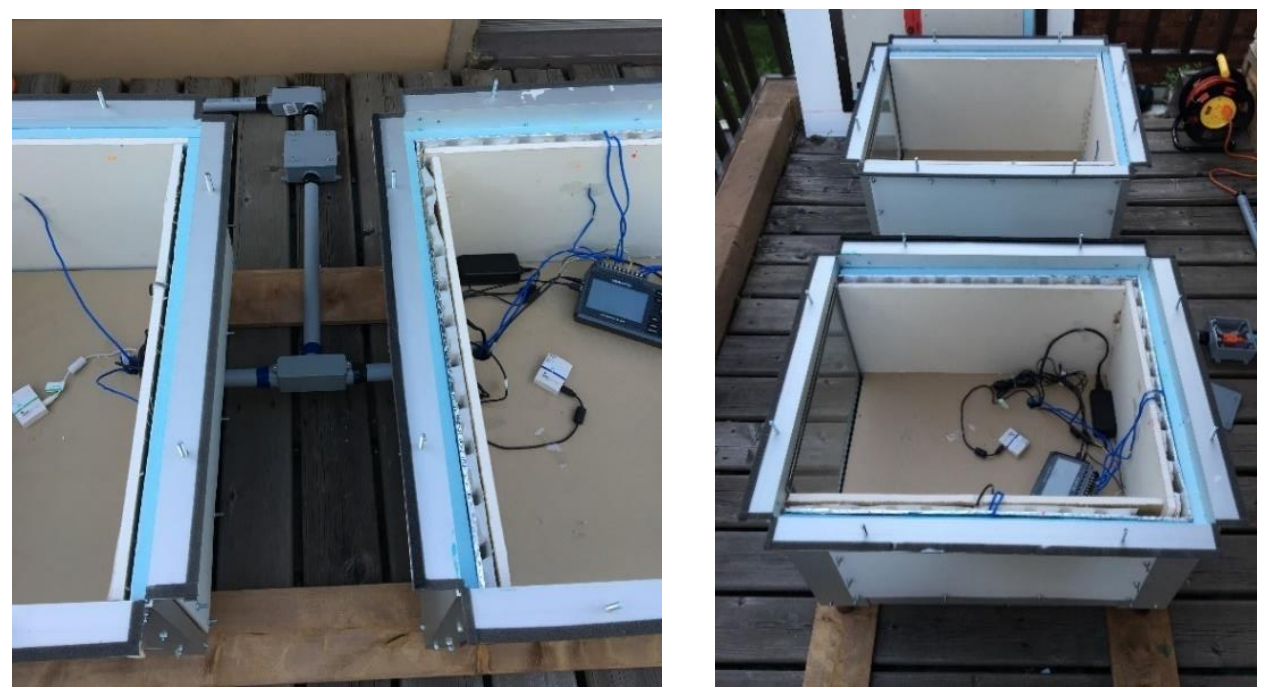

Figure 5.6- Connection of two test cells with PVC conduits

\section{Data collection}

Each test cell was quipped with one HOBO U-10-003 Data Logger to measure indoor air temperatures and relative humidity. Thermocouples and heat flux transducer were installed on wall and ceiling surfaces to measure the surface temperatures and heat flow rates. The heat flux sensor used for this study is an HFP01 Hukseflux heat flux plate which is a ceramic disc installed between the surface layers for this study. The position of these surface sensors differs in each test due to different testing parameters.

The data were recorded using a Graphtec data logger with 10 individual analog channels that were configured for direct connection of thermocouples as well as direct voltage measurements. Surface and indoor air temperatures and surface heat flow values were measured continuously with a time step of one minute for accurate monitoring of PCM activation patterns.

To measure outdoor temperatures a Netatmo weather station was installed on the site and positioned two meters behind the test cells. This standalone weather station provided real-time 
data for outdoor temperature and relative humidity. The test cells were connected to each other using PVC conduits with airtight connections to enable the accessibility of the reference test cell to the data logger located in the composite PCM test cell.

Table 5.4. Applied equipment for data acquisition

\begin{tabular}{|c|c|c|c|c|c|}
\hline Equipment & Measurement & Units & Accuracy & Position & Equipment Image \\
\hline $\begin{array}{l}\text { Netatmo } \\
\text { weather } \\
\text { station }\end{array}$ & $\begin{array}{l}\text { Outdoor ambient } \\
\text { weather temperature } \\
\text { and relative humidity }\end{array}$ & $\begin{array}{l}{ }^{\circ} \mathrm{C} \\
\% \mathrm{RH}\end{array}$ & $\begin{array}{l} \pm 0.3 \\
\pm 3 \%\end{array}$ & $\begin{array}{l}\text { One inside module } \\
+ \\
\text { One outside } \\
\text { module }\end{array}$ & \\
\hline $\begin{array}{l}\text { HOBO U-10- } \\
\text { 003 Data } \\
\text { Loggers }\end{array}$ & $\begin{array}{l}\text { Indoor air } \\
\text { temperature and } \\
\text { relative humidity }\end{array}$ & $\begin{array}{l}{ }^{\circ} \mathrm{C} \\
\% \mathrm{RH}\end{array}$ & $\begin{array}{r} \pm 0.5 \\
\pm 3.5 \%\end{array}$ & $\begin{array}{l}\text { Centre of each test } \\
\text { cell on the floor }\end{array}$ & \\
\hline $\begin{array}{l}\text { Pyromation } \\
\text { Insulated } \\
\text { Thermocoupl } \\
\text { e Type T }\end{array}$ & $\begin{array}{l}\text { Surface } \\
\text { temperatures }\end{array}$ & ${ }^{\circ} \mathrm{C}$ & $0.75 \%$ & $\begin{array}{l}\text { Centre of surfaces } \\
\text { and between } \\
\text { layers of walls and } \\
\text { ceilings }\end{array}$ & \\
\hline $\begin{array}{l}\text { HuskeFlux } \\
\text { HFP-01 }\end{array}$ & Heat flux Sensors & $\mathrm{W} / \mathrm{m}^{2}$ & $\pm 5 \%$ & $\begin{array}{l}\text { Between layers of } \\
\text { walls and ceiling }\end{array}$ & \\
\hline $\begin{array}{l}\text { GL-240 Data } \\
\text { Logger }\end{array}$ & 10 input channels & $\begin{array}{l}\text { Voltage } \\
{ }^{\circ} \mathrm{C}\end{array}$ & $\begin{array}{r}0.1 \% \\
+0.1 \%\end{array}$ & $\begin{array}{l}\text { Inside the } \\
\text { composite PCM } \\
\text { cell }\end{array}$ & \\
\hline
\end{tabular}

\subsubsection{Parameters of analysis}

The prominent variables for the experimental study were orientation and shading, while natural ventilation was also investigated. In total, five tests were conducted, each targeting specific parameters. Table 5.5 outlines a summary of all five tests and their variables with a graphical representation of studied parameters in each test cell. Figure 5.7 presents the timeline for all the tests showing an average testing period of 11 days. 
Table 5.5. Experimental test configuration and variables

\begin{tabular}{|c|c|c|c|}
\hline Test name & Variables & Description & Measured Parameters \\
\hline $\begin{array}{l}\text { Test \#1.1 } \\
\text { Test \#1.2 } \\
\text { Test \#1.3 } \\
\text { Test \#1.4 }\end{array}$ & $\begin{array}{l}\text { 1-Orientation } \\
\text { South } \\
\text { East } \\
\text { West } \\
\text { South } \\
\text { 2- Surface analysis: } \\
\text { Walls }\end{array}$ & $\begin{array}{l}\text { 1- Testing the impact of } \\
\text { orientation on the composite } \\
\text { PCM's performance. } \\
\text { 2- One side wall and the } \\
\text { window facing wall were } \\
\text { monitored. }\end{array}$ & 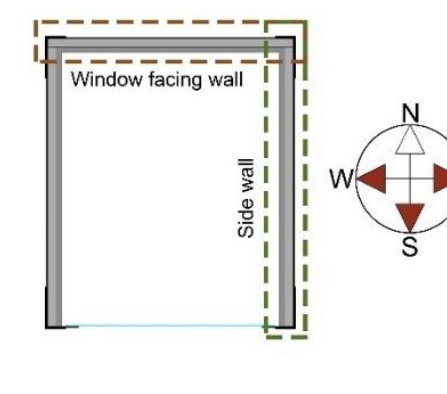 \\
\hline Test \# 2 & $\begin{array}{c}\text { Surface analysis: } \\
\text { Ceiling }\end{array}$ & $\begin{array}{l}\text { Comparison of incremental } \\
\text { change in the composite PCM } \\
\text { ceiling compared to rate of } \\
\text { change in the composite PCM } \\
\text { walls in test } \# 1 .\end{array}$ & 3 \\
\hline Test \# 5 & Individual PCM testing & $\begin{array}{l}\text { Separating PCM products to } \\
\text { investigate their daily cycles } \\
\text { and activation patterns } \\
\text { individually. [Energain Cell and } \\
\text { Bio PCM cell] }\end{array}$ & 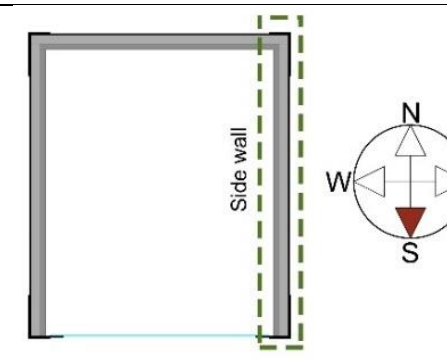 \\
\hline $\begin{array}{l}\text { Test \# } 3.1 \\
\text { Test \#3.2 }\end{array}$ & $\begin{array}{l}\text { 1- Orientation } \\
\text { South } \\
\text { East } \\
\text { 2-Surface analysis: } \\
\text { Wall + Ceiling }\end{array}$ & $\begin{array}{l}\text { 1- Investigating impact of } \\
\text { orientation on composite } \\
\text { ceiling performance. } \\
\text { 2- Simultaneous monitoring of } \\
\text { ceiling and walls }\end{array}$ & Ceiling \\
\hline Test \# 4 & $\begin{array}{l}\text { 1- Shading } \\
\text { 2- Night Ventilation }\end{array}$ & $\begin{array}{l}\text { 1- Shading over the window } \\
\text { was removed to assess the } \\
\text { influence of direct solar } \\
\text { radiation on PCMs. } \\
\text { 2- Night ventilation was } \\
\text { included on two nights to } \\
\text { monitor the rate of } \\
\text { solidification in the PCMs } \\
\text { during the night. }\end{array}$ & 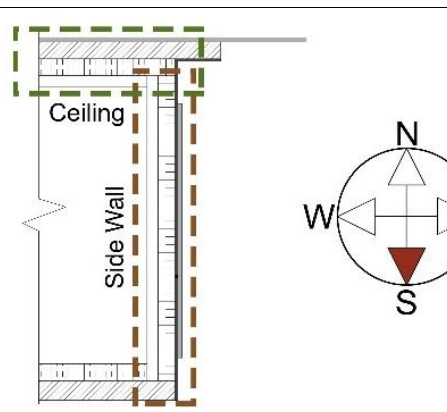 \\
\hline
\end{tabular}




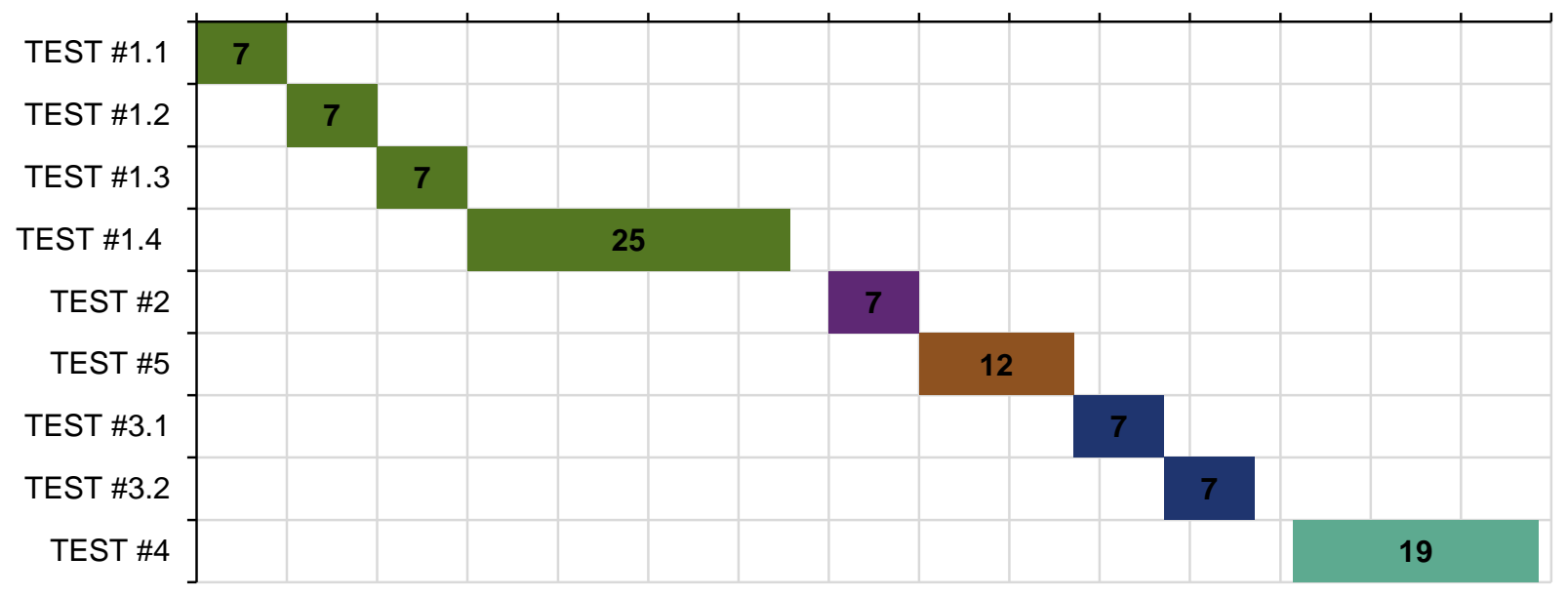

Figure 5.7- Experimental tests timeline

A comparative assessment between the reference test cell and the composite PCM test cell has been performed. The main parameters of analysis are the temperature profile, and heat flow of the PCMs in relation to ambient weather variations in the cells. The impacts of the composite PCM system are assessed on room and surface levels. The following parameters have been quantified:

\section{* Room Level}

The impact of composite PCM on regulating indoor room temperatures is assessed in the cells. This analysis includes the monitoring of temperature swings, the rates of heat loss and heat gain in the space in relation to time of day.

Parameters of analysis:

- Rate of temperature change in the composite PCM surfaces;

- Maximum and minimum peak temperatures in each room;

- Diurnal Temperature fluctuations;

- Peak temperature shifts

\section{* Surface Level}

This analysis is required to demonstrate the exact performance and activation pattern of PCM products incorporated in the walls and ceilings. In addition to surface temperatures, evaluation of heat flow through each surface indicates the mechanism of heat gain and heat release. The temperatures are analyzed based on the melting range of the two PCM products. Moreover, multi surface analysis is also required between the wall and ceiling applications.

Parameters of analysis:

- Surface temperature variations in two rooms;

- Heat flow patterns in relation to time of day;

- Comparison of heat flow and surface temperature of ceiling and wall;

- Rate of PCM activation in each PCM product in the composite PCM system; 
* Comprehensive analysis:

This final evaluation is focused on connecting the main variables with the measured data.

- Correlation analysis 1: Influence of orientation on indoor temperature fluctuations

- Correlation analysis 2: Influence of shading and no shading situations on indoor temperature and surface temperature

- Correlation analysis 3: Influence of natural ventilation on indoor room temperatures

The main comparison in the experimental tests is between the two test cells, thus the term "rate of change", is referred to the changes perceived in the composite PCM test cell as opposed to the reference test cell. However, as the tests are all performed in different time periods their results are not directly comparable. Therefore, incremental changes caused by the PCM is measured and compared between test results.

\subsection{Results}

\subsubsection{Test \#1 - Testing the impact of orientation}

In a 45-day period, data were collected from sensors positioned on two walls, one side wall and one window facing wall. The main variable tested is orientation to assess the influence of solar radiation on PCM performance. Test cells are rotated to three orientations of south, east, and west for a minimum period of seven days. As indicated in Figure 5.8, sensors are positioned across three layers of the composite PCM walls while surface temperatures are measured in the reference walls.

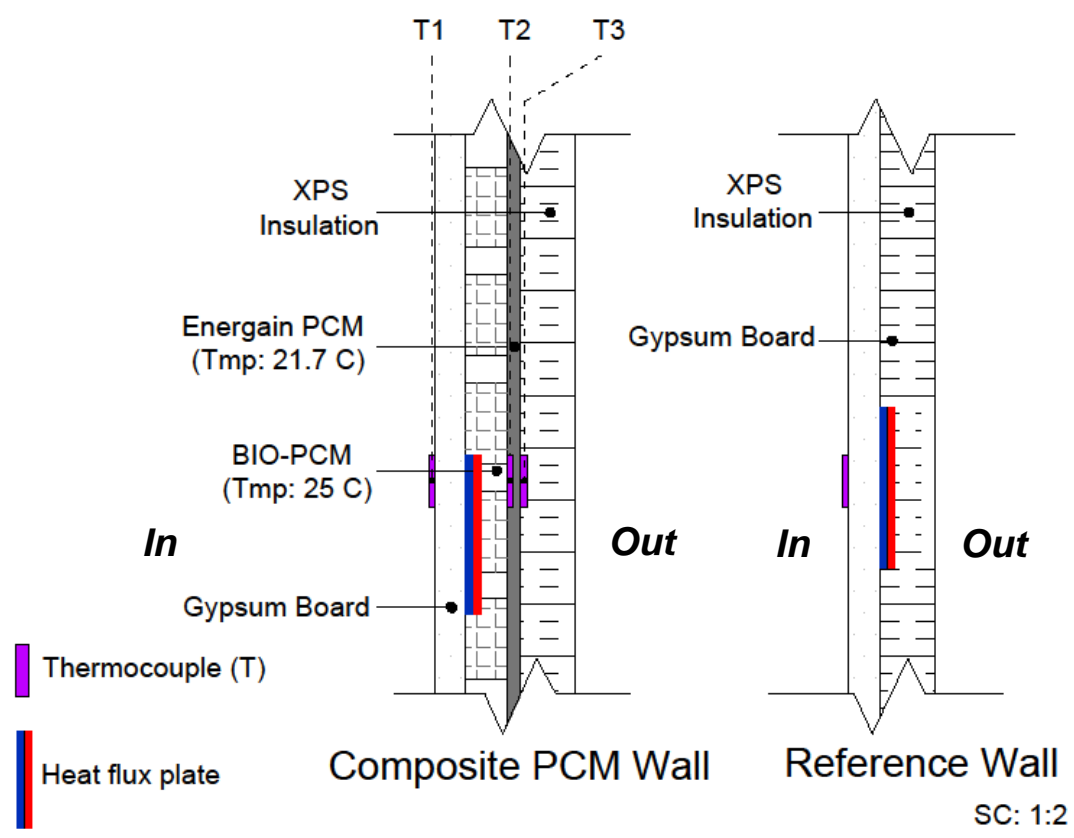

Figure 5.8. Sensor positions on walls in Test \#1 
Figure 5.9 demonstrates the weekly average high and low peak indoor air temperature values in each orientation in the month of July. The maximum rate of change in the composite PCM test cell occurs in the two highest and lowest weekly peak temperatures recorded. The influence of composite PCM shows $9 \%$ reduction of high peak temperatures in the west and $22 \%$ increase in low peak temperatures in the south orientation. It is evident that the composite PCM system is more effective in extreme situations as the highest percentage of change is observed in the highest and lowest peak temperatures recorded.

A rising trend is observed as indoor room temperatures increase from the south facing to the west facing scenario. However, due to different ambient conditions, these three orientations could not be directly compared. Nevertheless, the average outdoor weather conditions in the west facing and south facing periods in July are quite similar, on average the daily outdoor temperature is $23.5^{\circ} \mathrm{C}$ in both weeks. Thus, it could be suggested that the impact of solar heat gain in the west orientation is larger on indoor air temperatures which consequently entails the highest rate of change caused by the composite PCM system.

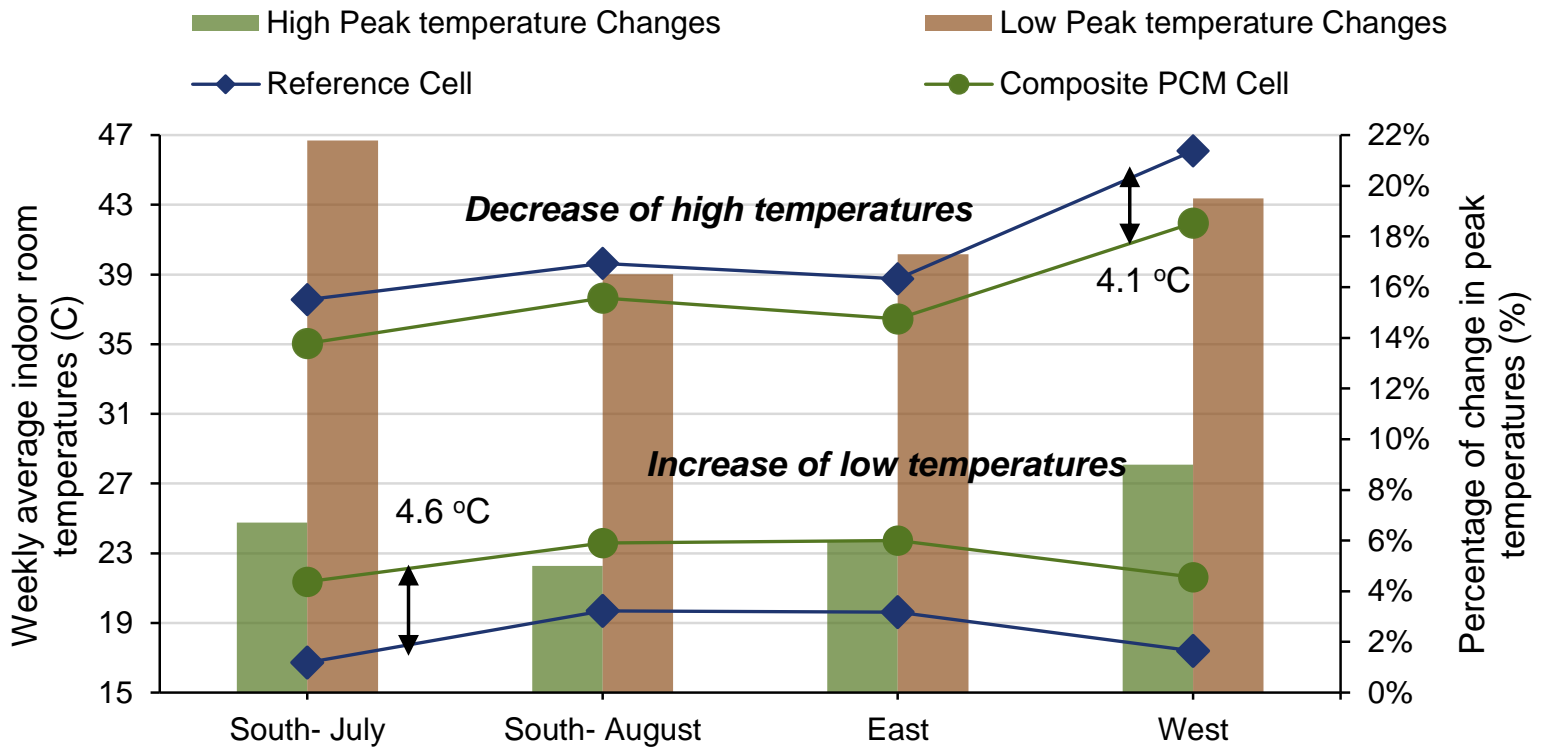

Figure 5.9. Correlation of orientation and peak indoor room temperatures

By investigating the detailed solar information on the test site, the different behavior of PCMs in extreme peak periods is determined as a key difference between the three orientations. As shown in Fig. 5.9, the three periods are all in the month of July, average daily sunshine hours are the same for each testing period, however, the maximum indoor temperatures in each test cell occurs at different times of the day.

When the cells are facing south, air temperature of the cells reaches its maximum level every day between 3 to $5 \mathrm{pm}$ similar to the east facing scenario in which the maximum temperature is reached from 4 to $5 \mathrm{pm}$. As for the west orientation, however, the highest air temperature in both cells is reached near the sunset period from 6 to $7 \mathrm{pm}$. This shows the periodical impact of solar gain in the units in changing indoor temperatures as well as PCMs' performance. 


\section{South Orientation}

The test cells were exposed to the south for four weeks (July $1-7^{\text {th }}$ and July $22^{\text {nd }}-$ August $15^{\text {th }}$ ). As Figure 5.10 presents, the sinusoidal temperature changes in the cells are more controlled in the composite PCM test cell. Overall air temperature swings are reduced by $6.8^{\circ} \mathrm{C}$ as a result of extreme temperature regulation. In particular, the effectiveness of the composite system at night is significant in maintaining indoor temperatures as air temperatures of the reference cell drop 2 ${ }^{\circ} \mathrm{C}$ below the ambient weather. An apparent peak temperature shifting of one hour happens in the composite PCM test cell. The maximum air temperature is shifted to later afternoon as a result of thermal lag in the composite PCM test cell.

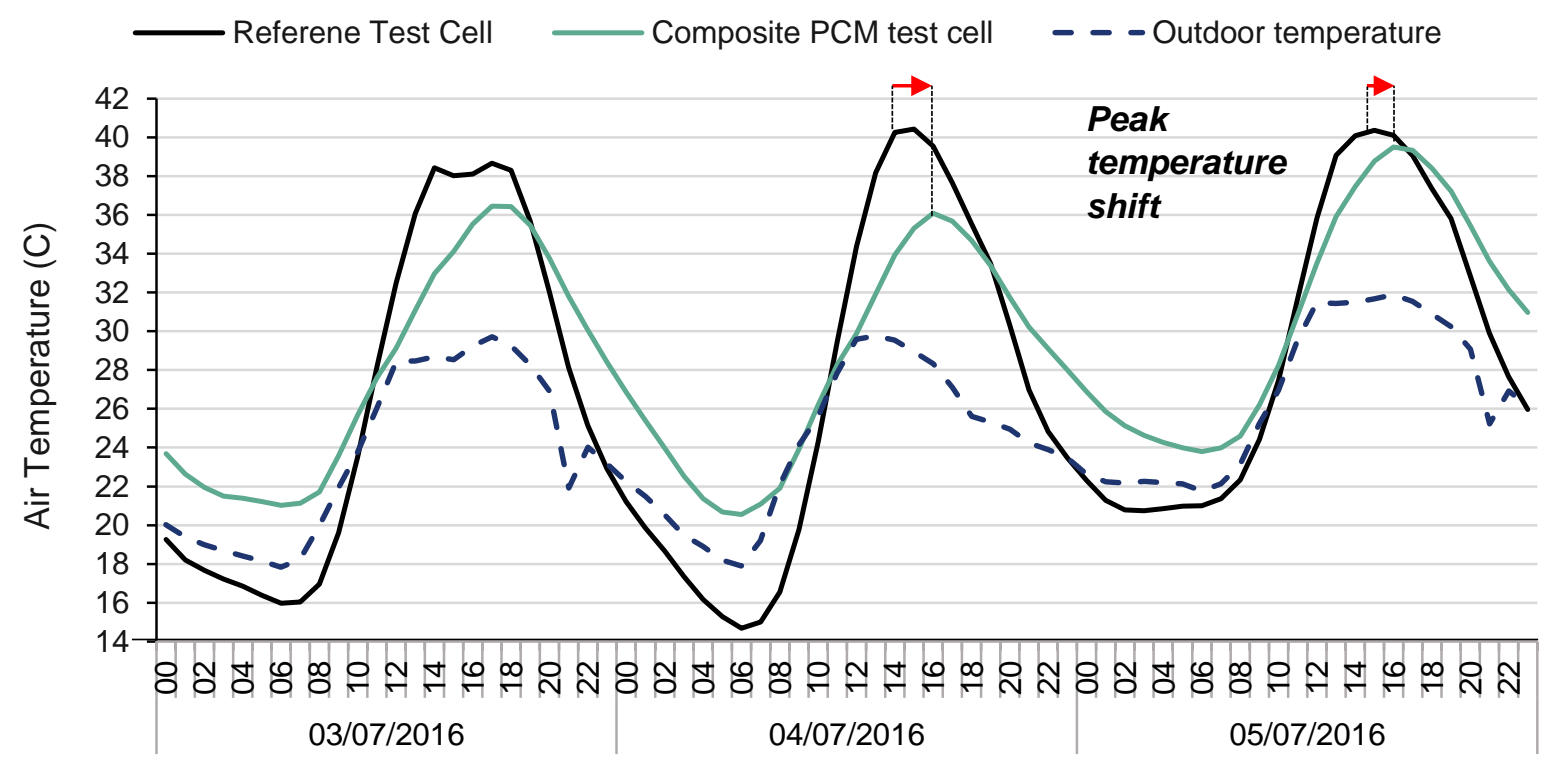

Figure 5.10- Hourly indoor room temperatures from July $3^{\text {rd }}-5^{\text {th }}$

Comparing three days in July and August shown in Figures 5.10 and 5.11, the effect of outdoor temperatures is demonstrated. The rate of temperature variations outside and in both test cells are assessed in three different periods in each day. The main period of temperature increase in both months is from 6 am to $12 \mathrm{pm}$. During this period, the average rise in temperature in the reference test cell is $47 \%$ higher than the temperature increase recorded in the composite PCM cell. Concerning the heat loss at night following temperature drops from $6 \mathrm{pm}$ to 6 am the next day, a similar pattern could be observed with better performance of the composite PCM cell by $29 \%$ in retaining night temperatures.

In general, due to thermal capacity in each room, indoor room temperatures are always higher than the ambient temperatures during the day. When the ambient temperatures are higher as in August, the increase of air temperature in the cells are in line and closer to the ambient temperatures whereas in July with smaller temperature increase outside, there is a larger increase rate in indoor temperatures. This difference could be a result of high night temperatures in August which causes an early melting for the PCM during the day. This early melting and temperature stabilization in August contrasts with July days in which a longer time is required for indoor air and surfaces to warm up and reach the PCMs' melting range. 


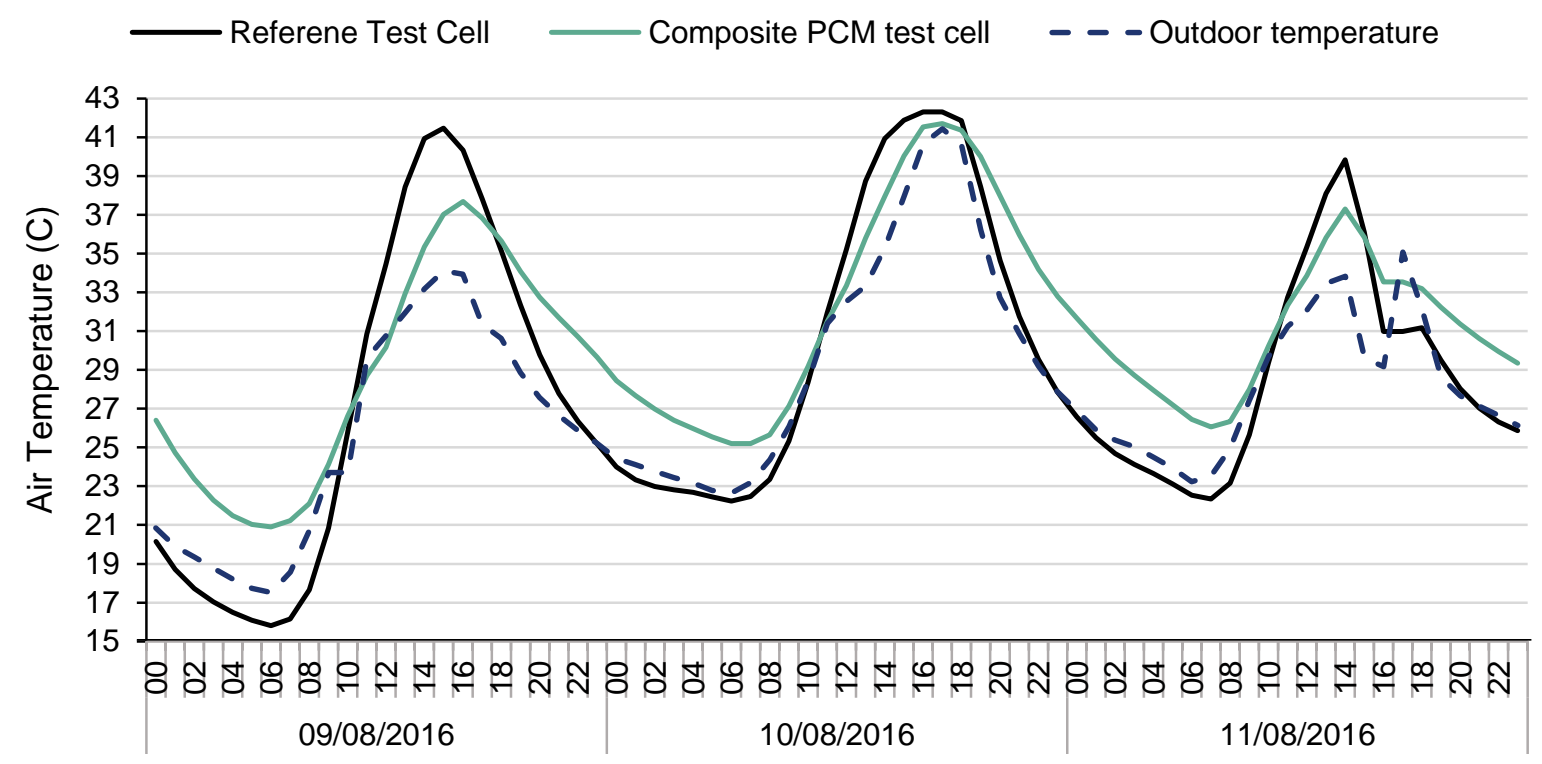

Figure 5.11- Hourly indoor room temperatures from August $9^{\text {th }}-11^{\text {th }}$

Average outdoor temperatures in August days are $2.9^{\circ} \mathrm{C}$ higher than the July days. The results show that with an incremental outside temperature rise of $8.2^{\circ} \mathrm{C}$ in August days, air temperature of reference test cell rises by $10.6^{\circ} \mathrm{C}$, while in the composite PCM cell, this temperature increase is limited to $7.8^{\circ} \mathrm{C}$. However, with $4.7^{\circ} \mathrm{C}$ increase in outdoor conditions in July days, indoor air of reference cell is increased by $9^{\circ} \mathrm{C}$ and indoor air of PCM cell rises by $7^{\circ} \mathrm{C}$.

The average indoor air temperature of the composite PCM test cells is $17.3 \%$ higher than the average daily ambient temperature. This difference drops to $11 \%$ in the composite cell as the temperature rise in the month of August shows how the outdoor and indoor conditions become closer.

\section{East Orientation}

Indoor temperatures start to increase as the sun rises from 6 am, but similar to the south orientation the high peak temperatures are reached in the afternoon. The in-depth analysis of the surface temperature and heat flow patterns in Figure 5.12 presents the detailed process of heat gain and heat release in the side walls.

Based on the parameters of the installed heat flux transducer and its position on the wall, negative heat flow values indicate heat gain in the wall which means heat loss from the room. Positive values show heat loss from the wall meaning heat gain in the room. As the graph shows a parallel relation exists between surface temperature variation and heat flow patterns in the side wall. As the surface temperatures increase surface heat gain values also rise, and the same procedure takes place for falling surface temperatures and heat loss from the surfaces.

Considering the sunrise hour in these days in July at 5:55 am, the sharp increase in surface temperatures of the reference wall could be explained. In the composite PCM wall, however, the 
temperature rise is more gradual until the maximum is reached approximately 2 hours after the maximum temperatures of the reference wall.

Heat flow transmission trough PCMs is a direct indication of the heat storage patterns in these materials which are dependant on their melting range. Regarding the melting temperatures of each PCM in the composite PCM system- Energain's $\mathrm{T}_{\mathrm{mp}}: 18-22{ }^{\circ} \mathrm{C}$; Bio PCM's $\mathrm{T}_{\mathrm{mp}}: 21.1-25$ ${ }^{\circ} \mathrm{C}$ - Figure 5.12 could be explained. For instance, starting from the night of July $9^{\text {th }}$, the surface temperatures start to drop from $5 \mathrm{pm}$ until they reach the temperature of $25^{\circ} \mathrm{C}$ in the composite $\mathrm{PCM}$ wall at $10 \mathrm{pm}$. As this declining trend continues overnight, the heat flow is increasing in both walls. The coldest surface temperatures are experienced early morning on July $10^{\text {th }}$, from 4 to $6 \mathrm{am}$, which is when the highest value for the heat release is also reached.

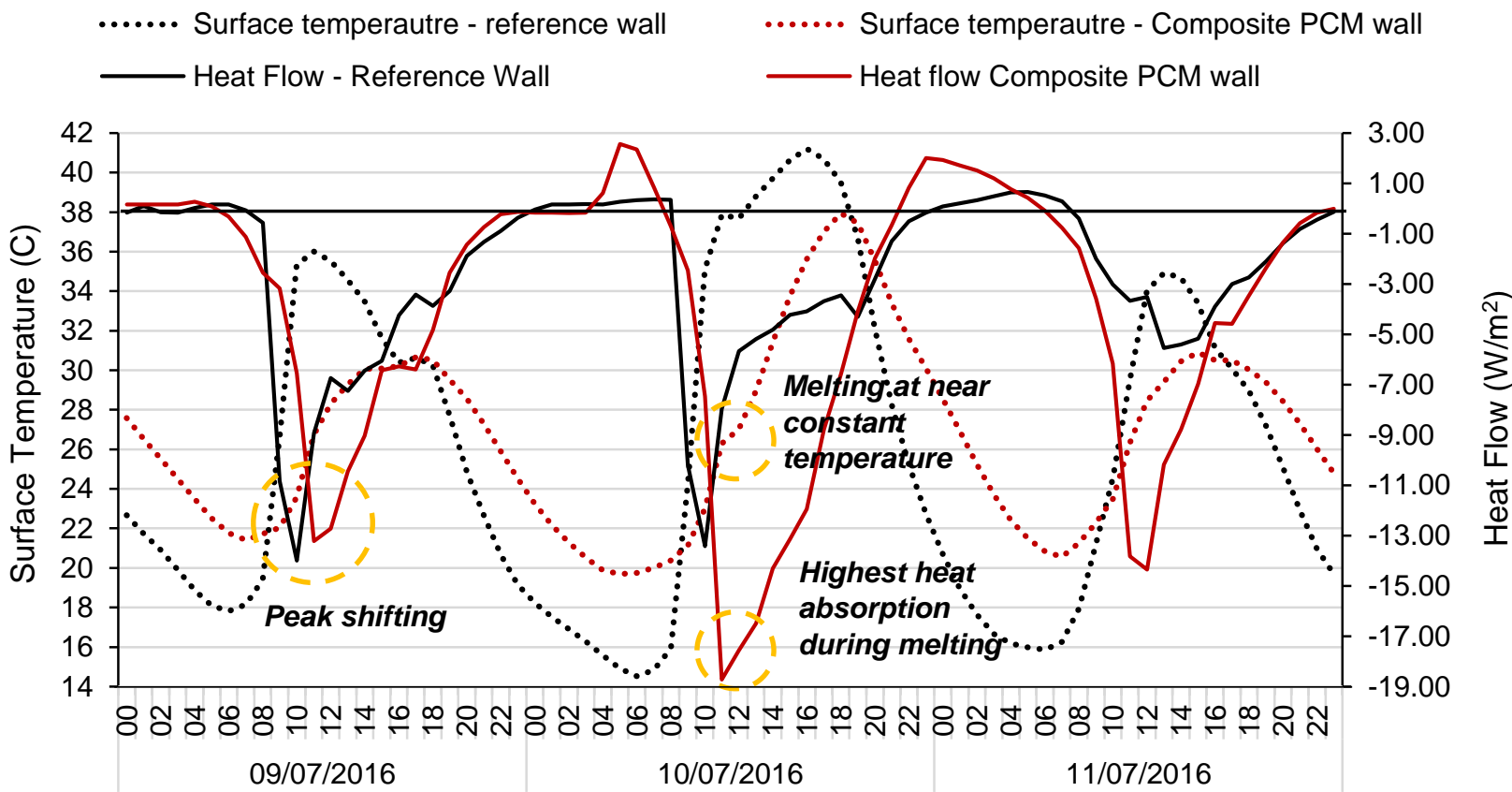

Figure 5.12- Hourly Surface temperatures for the side wall - East Orientation

At 6 am on July $10^{\text {th }}$, the surface temperature recorded for the composite PCM wall is $19.7^{\circ} \mathrm{C}$, which is $2^{\circ} \mathrm{C}$ below the freezing point of the Bio PCM layer, this explains the high heat release of $3 \mathrm{~W} / \mathrm{m}^{2}$ to the room. This high heat loss from the walls represents full solidification of Bio PCM layer. In comparison to the reference wall, a higher surface temperature is observed at night indicating the ability of the composite PCM system to maintain night temperatures close to the melting point of the PCMs for longer periods. In night of July $9^{\text {th }}$, with temperatures dropping to $25^{\circ} \mathrm{C}$ at $10 \mathrm{pm}$, the overall range of temperature fluctuations is $6{ }^{\circ} \mathrm{C}$ over 10 hours up to the start of next cycle in the next morning. In the same period at night, reference wall temperatures experience an $11^{\circ} \mathrm{C}$ temperature variations.

\section{West Orientation}

Changes in indoor room temperatures in this week follow the same trend as previous weeks, showing a better performance in the composite PCM test cell. However, significant changes 
were observed from July $15^{\text {th }}-22^{\text {nd }}$ as demonstrated in Figure 5.13. Unlike south and east facing orientations, highest temperatures in the test cells occur close to the sunset period from 5 to 7 $\mathrm{pm}$. On July $16^{\text {th }}$ and $18^{\text {th }}$, temperatures inside the reference cell reach as high as $50^{\circ} \mathrm{C}$ at 7 $\mathrm{pm}$. This figure demonstrates a higher solar heat gain impact on indoor temperatures in the west orientation considering a similar ambient temperature profile to previous weeks in south and east facing cases.

Another distinctive pattern in this week is the rapid transition of temperatures at night without solar radiation. In the east and south orientations, the night temperatures in both test cells decrease over time and at a slower rate. However, in the west orientation, the large swing observed on the $16^{\text {th }}$ and the $18^{\text {th }}$ are as much as $33^{\circ} \mathrm{C}$ in the reference test cell and $21^{\circ} \mathrm{C}$ in the composite PCM test cell through the night. This large temperature fluctuation could pose significant comfort problems in a building.

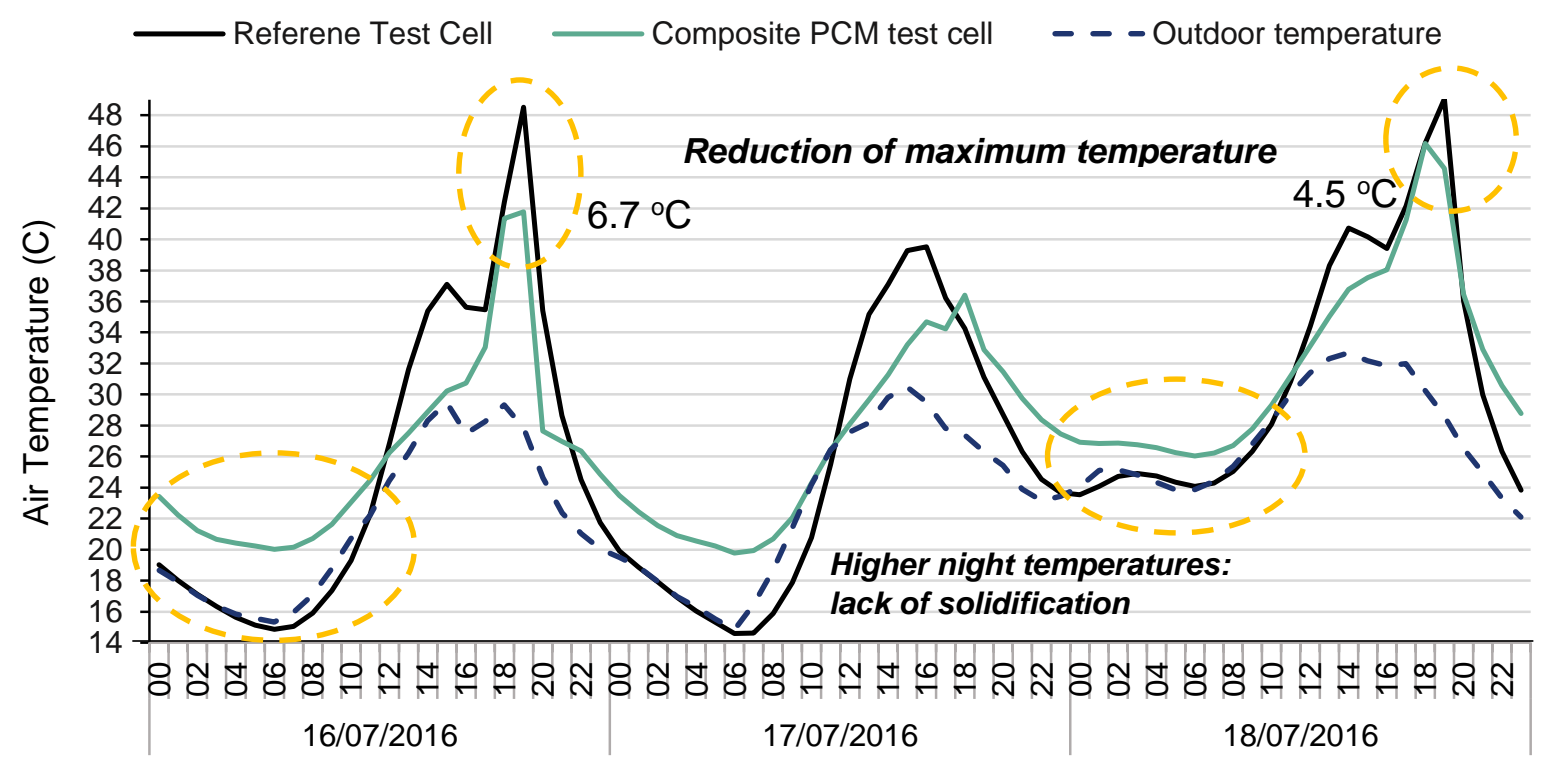

Figure 5.13- Hourly Indoor Room temperatures from July $15^{\text {th }}-22^{\text {nd }}$

Concerning the efficiency of the composite PCM, Figure 5.13 shows that on July $16^{\text {th }}$, the composite PCM's cell temperature is $41.7^{\circ} \mathrm{C}$ which is $7^{\circ} \mathrm{C}$ below the reference room's temperature. Nevertheless, one of the key problems associated with PCMs is the inability of full solidification process at night due to high night temperatures not reaching the melting point. This issue was identified in this research as well. For instance, on July $17^{\text {th }}$, outdoor night temperatures were nearly $9^{\circ} \mathrm{C}$ above the previous night's temperatures, to an average of 23.9 ${ }^{\circ} \mathrm{C}$. This increase also entails higher indoor cell temperatures greater than the melting point of the composite PCM system.

When PCMs do not discharge the stored energy at night, they lose their heat storage ability in the next cycle as they stay melted. This is evident on July $18^{\text {th }}$, with outside temperatures and indoor reference cell temperatures similar to those of July $16^{\text {th }}$. However, lack of PCM solidification at night of July $17^{\text {th }}$ degrades the performance of the composite PCM test cell in reducing the maximum temperature on the $18^{\text {th }}$ as illustrated in Figure 5.13. 
One of the prominent solution stated in reviewed studies is the inclusion of night cooling. Night cooling could facilitate the solidification process of PCMs preparing them for sufficient heat storage in the coming day. This factor has been investigated in test \#4 in section 5.2.4.

\section{Comparison of window facing and side wall}

Comparing the difference between the window facing wall and one side wall, the results show that in each week in test \#1 period, the surface temperature of the window facing wall in both reference and composite PCM test cell are higher than the monitored side wall. This could be a clear indication of the higher effect of solar radiation on the window facing wall. Thus to compare the impact of PCM in changing surface temperatures, Table 5.6 shows the rate of change in the composite PCM surfaces form the reference surfaces.

The integration of the composite PCM causes a $7.6^{\circ} \mathrm{C}$ decrease in the overall amplitude in the side wall and for the window facing wall, this decrease is $7.9^{\circ} \mathrm{C}$ considering the south facing orientation in July. The average temperatures of the window facing wall are particularly higher in when the unit is rotated to the east and west due to intense solar radiation. Table 5.6 presents that as the average temperatures are higher in the window facing wall, the impact of PCM in increasing low temperatures is higher on this surface. These outcomes are consistent with results of the study done by Kuznik et al. (2009a) which shows a higher PCM performance in window facing walls.

Table 5.6. Impact of the PCM system on different walls of the composite PCM test cell

\begin{tabular}{|l|c|c|c|c|c|c|}
\hline $\begin{array}{c}\text { Rate of Change } \\
\text { by composite } \\
\text { PCM }\end{array}$ & \multicolumn{2}{|c|}{$\begin{array}{c}\text { Average surface } \\
\text { temperatures }\left({ }^{\circ} \mathrm{C}\right)\end{array}$} & $\begin{array}{c}\text { Reduction of Max. } \\
\text { Surface temperatures } \\
\left({ }^{\circ} \mathrm{C}\right)\end{array}$ & $\begin{array}{c}\text { Increase of Min. } \\
\text { Surface temperatures } \\
\left({ }^{\circ} \mathrm{C}\right)\end{array}$ \\
\hline Orientation & Side Wall & $\begin{array}{c}\text { Window } \\
\text { Facing wall }\end{array}$ & Side Wall & $\begin{array}{c}\text { Window } \\
\text { Facing wall }\end{array}$ & Side Wall & $\begin{array}{c}\text { Window } \\
\text { facing wall }\end{array}$ \\
\hline South-July & $+1.5^{\circ} \mathrm{C}$ & $+1.8^{\circ} \mathrm{C}$ & $-1.8^{\circ} \mathrm{C}$ & $-1.6^{\circ} \mathrm{C}$ & $+5.7^{\circ} \mathrm{C}$ & $+6.3^{\circ} \mathrm{C}$ \\
\hline East & $+0.7^{\circ} \mathrm{C}$ & $+1.2^{\circ} \mathrm{C}$ & $-2^{\circ} \mathrm{C}$ & $-1.8^{\circ} \mathrm{C}$ & $+5.2^{\circ} \mathrm{C}$ & $+5.6^{\circ} \mathrm{C}$ \\
\hline West & $+0.5^{\circ} \mathrm{C}$ & $+0.9^{\circ} \mathrm{C}$ & $-7.8^{\circ} \mathrm{C}$ & $-6.7^{\circ} \mathrm{C}$ & $+6.2^{\circ} \mathrm{C}$ & $+6.6^{\circ} \mathrm{C}$ \\
\hline
\end{tabular}

\subsubsection{Test \#2 - Testing the ceiling}

In a one-week period the test cells are facing south and the ceilings in both cells are monitored. Figure 5.14 shows the sensor positioning on the ceilings for this testing period. The aim is to compare the incremental changes in the ceiling to the walls monitored in test \#1. Measured data on test cells' side walls recorded in a week in August during test \#1 in which test cells were facing south are compared to the recorded data on ceilings in this week of test \#2. In the week of test \#2 daily indoor temperatures vary on average between $21.9^{\circ} \mathrm{C}$ and $35.8^{\circ} \mathrm{C}$. The indoor temperature variations in the week of test $\# 1$ are from $23.6^{\circ} \mathrm{C}$ and $37.6^{\circ} \mathrm{C}$. 


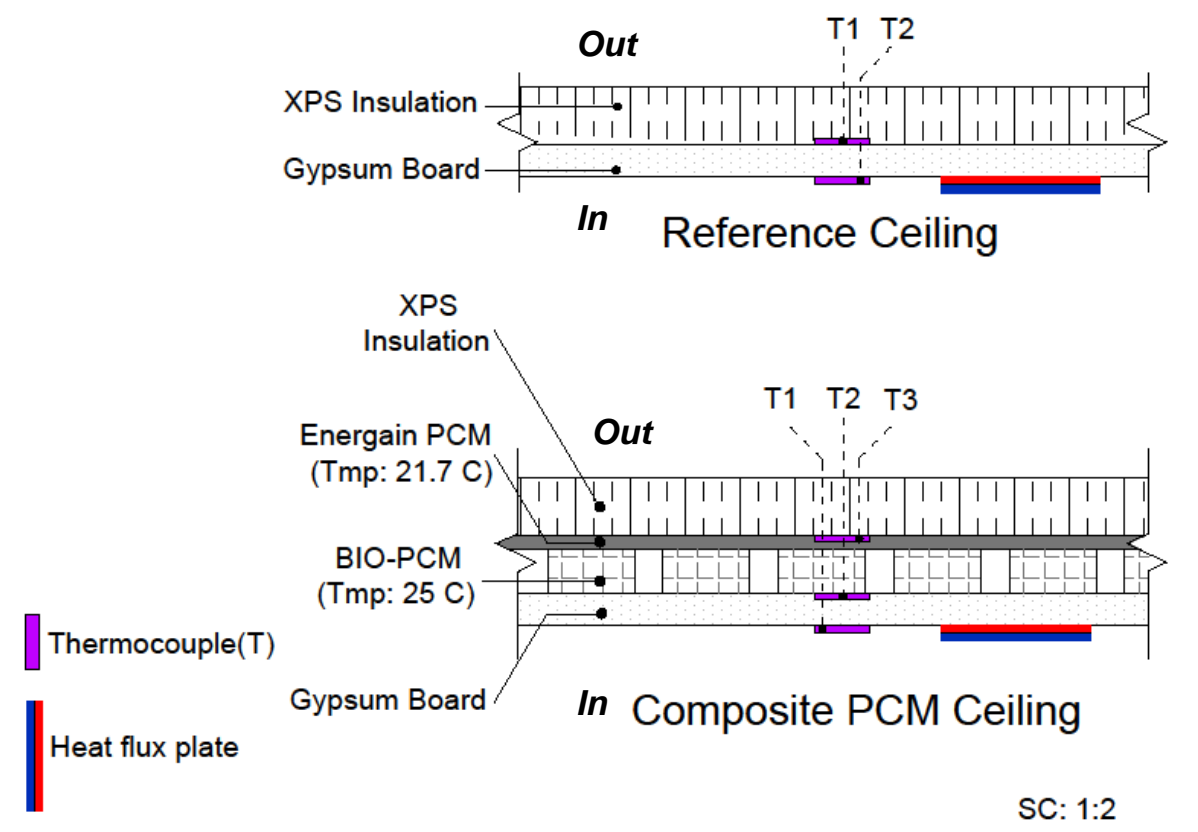

Figure 5.14- Sensor positioning on the ceilings in test \#2

Total average rate of daily heat transfer through both reference and composite PCM ceilings are noticeably more than the rate of heat transfer in the walls shown previously. The surface area of composite PCM ceiling is slightly larger than the surface area of the side composite wall. Correspondingly the change rate of heat transfer and surface temperature values are more significant in the composite PCM ceiling. Particularly, the composite PCM ceiling shows a greater rate of heat gain, $6.3 \mathrm{~W} / \mathrm{m}^{2}$ more on average than heat gain changes caused in the composite PCM wall.

The rate of increase in heat gain and heat loss in the PCM integrated wall and ceiling surfaces is compared in Figure 5.15. In the reference wall as temperatures drop, heat moves towards outwards. Heat release from the composite PCM wall to the room is clearly observed as it compensates for the heat loss from the room. However, this value is much smaller in the composite ceilings, as the average heat release to the room through the reference ceiling is also high at night entailing a smaller gap between the reference and the composite PCM ceiling.

In contrast, the great difference in heat gain capability of the ceiling is more notable. The overall conclusion is that PCMs integrated into the ceiling have better performance in absorbing and storing the excess heat which could be due to natural convection and nature of heat transfer. In a previous study done by Muruganantham, (2010) similar results were obtained by testing Bio PCM products, in which higher melting range products were selected for the ceiling application. The detailed graph representing heat flow values in the ceilings and the side walls in each week is presented in Appendix II.

From the results, it could be inferred that the integration of the proposed composite PCM in the ceiling is more effective, however, it is necessary to consider the surface area of the wall and ceiling applications. Moreover, to analyze the surface temperatures with regards to indoor temperature changes, both ceiling and walls need to be monitored at the same time. This factor is tested in test \#3 discussed in section 5.2.3. 


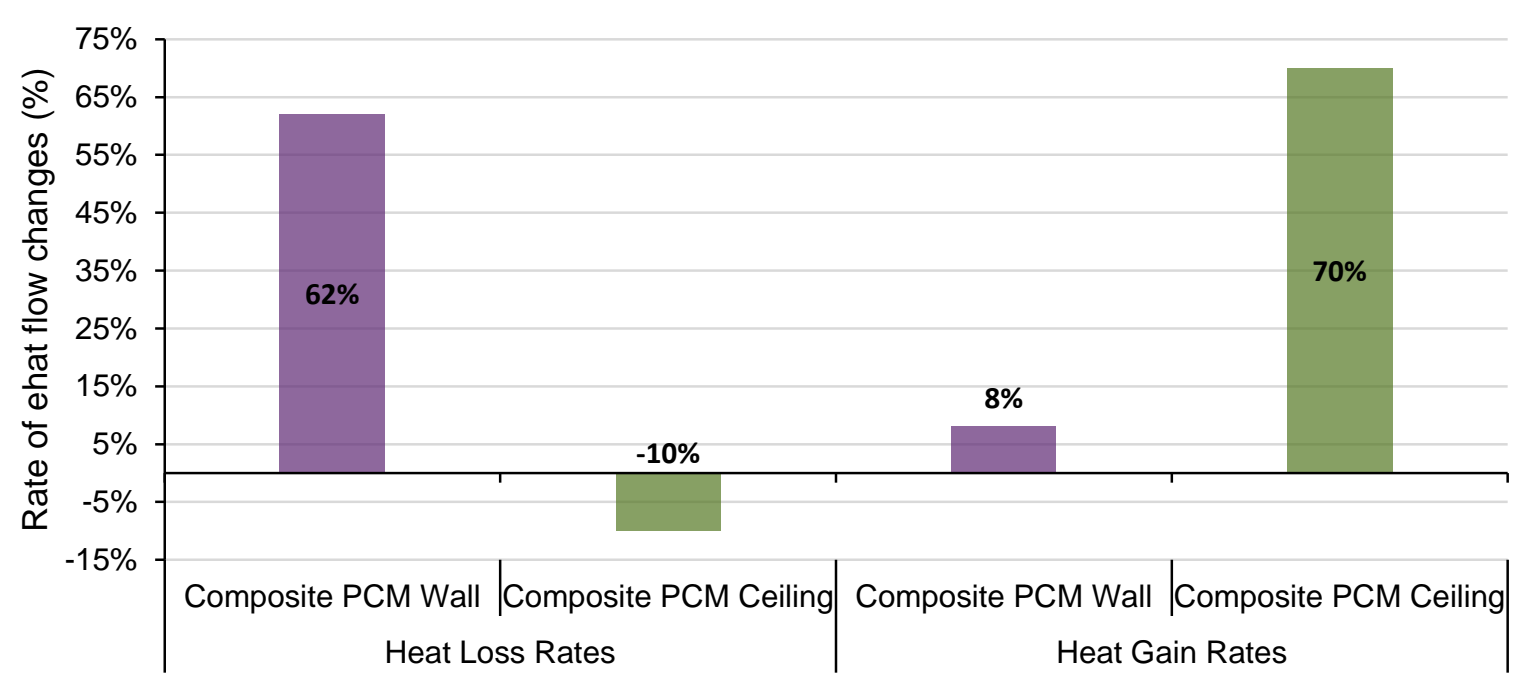

Figure 5.15- Rate of heat transfer change between composite PCM and reference surfaces

To analyze temperatures in each layer of the composite PCM ceiling and wall, measurements on three specific points in the composite PCM walls and ceilings are compared-sensor placements are shown Figures 5.8 and 5.15. Figure 5.16 shows that the incremental changes in between the ceiling layers are higher compared to the wall layer temperatures that are closer to each other. The trend shows more fluctuations in point T3, located between insulation and Energain in both composite applications, particularly in the composite PCM ceiling. It must be noted that the temperature profile shown in this figure is not directly comparable as the tests are conducted in two different periods. The focus is on the rate of change between inner surface layers of the composite PCM wall and ceiling.

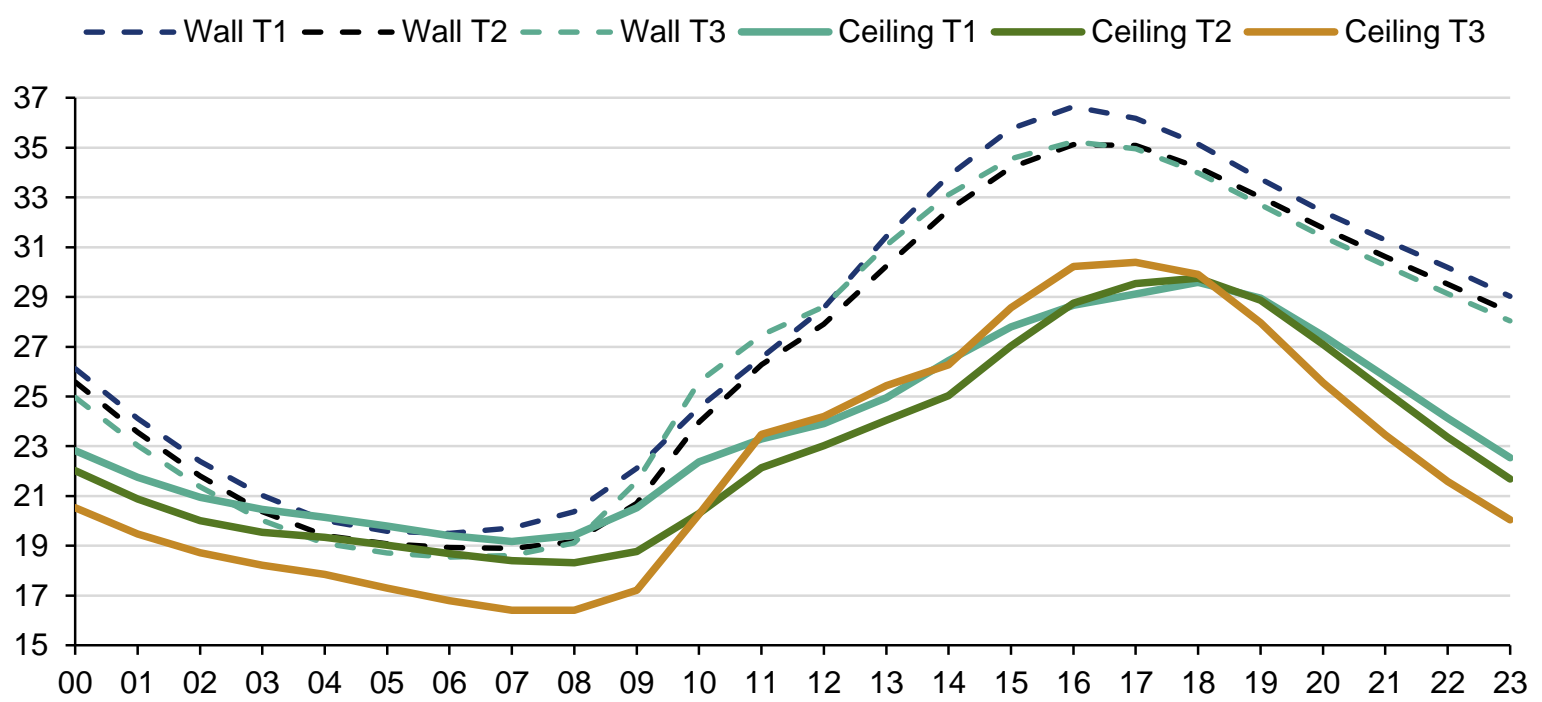

Figure 5.16- Layer temperatures in composite PCM wall and ceiling on August $9^{\text {th }}$ and $22^{\text {nd }}$ 
Comparing the overall fluctuations in T3 with T2 in the composite PCM walls and ceiling, shows that the effect of outdoor temperature is controlled in layer T2 as this layer shows constant temperature changes after phase change in the system. Furthermore, comparing the temperature variations across the composite PCM ceiling with the reference ceiling confirms this point. Temperature fluctuations across the reference ceiling are $20^{\circ} \mathrm{C}$, while on the composite PCM ceiling between $\mathrm{T} 3$ and $\mathrm{T} 2$ layers this fluctuation is $11.3^{\circ} \mathrm{C}$ respectively. The same pattern exists considering the indoor conditions, as the impact of the indoor room is controlled in layers T1 and T2 in the composite PCM surfaces.

\subsubsection{Test \#3 - Testing one wall and one ceiling}

The focus of this test is to simultaneously monitor ceiling and wall surface temperature variations. Thus, one side wall and the ceiling in both test cells are investigated. In addition to the south orientation, test cells are rotated to the east to examine the impact of solar radiation on the ceiling surface as well. The primary parameter of analysis in this section is the difference between the wall and ceiling surface temperature changes in relation to the room temperature. In addition, as test \#3 was conducted in September, the effect of weather variations is also a key parameter to be observed.

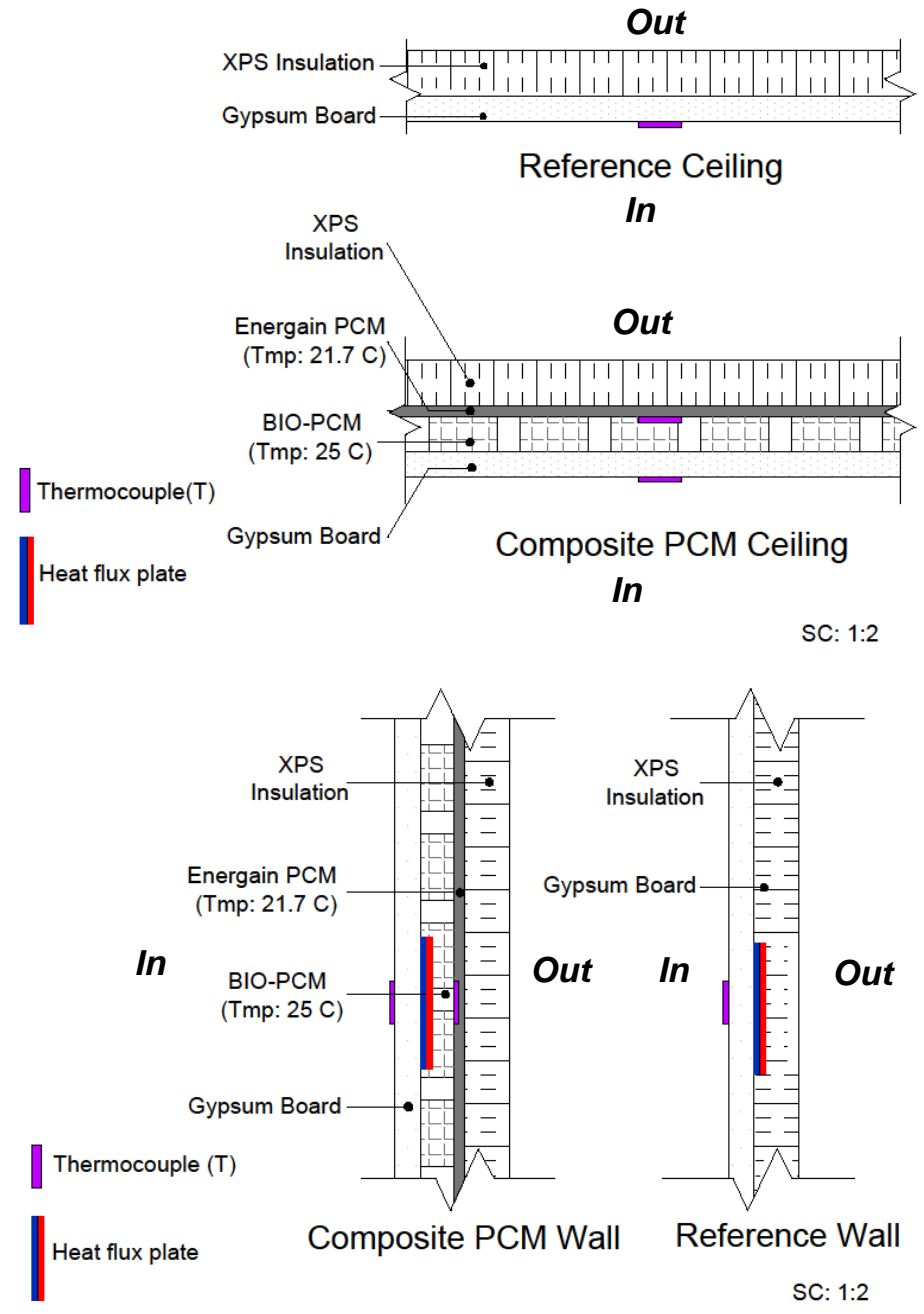

Figure 5.17- Sensor positioning on one wall and ceiling in test \#3 
The hourly surface temperatures in the composite PCM wall show a faster response to ambient and indoor room temperature variations. During the day, the wall heats up more rapidly and at night loses heat faster as temperatures start to decrease compared to the composite PCM ceiling. The thermal resistance of the composite PCM ceiling is $1.2 \mathrm{~m}^{2} . \mathrm{K} / \mathrm{W}$, while this value for the composite PCM wall is $0.9 \mathrm{~m}^{2} . \mathrm{K} / \mathrm{W}$. This higher resistance of the composite PCM ceiling retains the heat for a longer period at night preventing the ceiling's surface temperatures from losing heat at the same rate as the wall surfaces in the test cell. On average the composite PCM ceiling keeps surface temperatures higher for 3 hours at night.

Considering the phase transition, surface temperatures of both composite PCM ceiling and wall fall within the melting range of the composite PCM system at approximately the same time during the day. However, regarding the amount of PCM applied to each surface, a higher surface area for the Energain board accounts for $0.33 \mathrm{Kg} / \mathrm{m}^{2}$ in the ceiling which is slightly higher than the amount of Energain in the wall. Conversely, the amount of Bio PCM in the composite PCM ceiling is $0.24 \mathrm{Kg} / \mathrm{m}^{2}$ which is lower than the amount of this PCM in the side composite PCM wall. This slight difference is more pronounced after the surface temperatures exceed the melting threshold of both PCMs meaning that both PCM layers are melted. The sensible gain of the composite PCM ceiling is higher after the melting phase since the higher heat capacity of the Energain board leads to higher sensible storage and thus higher temperature rise after latent storage phase.

Assessing the effect of east orientation on the ceiling showed a different behavior in the early morning compared to the south orientation scenario. In the reference test cell in the mornings at 9 am on each day a sharp temperature rise is recorded in both reference wall and reference ceiling. However, the temperature of the reference ceiling is increased by nearly $5^{\circ} \mathrm{C}$ more than the reference walls at this time. Comparing the rate of changes and surface temperature stabilization between the PCM integrated surfaces, a higher impact of solar radiation is observed in the ceiling, particularly in morning periods. In the south orientation, however, no sharp temperature transition could be observed as the solar radiation is more diffused.

The frequency of PCM activation is assessed to evaluate how much each PCM layer undergoes phase change or stays in melted or solid phase. The activation of PCMs is referred to as the number of times the surface temperature of each PCM product in the composite PCM system falls between their corresponding PCM's melting range. Figure 5.18 presents the activation of both the composite PCM ceiling and wall when test cells are facing south and east orientations.

Since the south facing and east facing tests took place in different weeks, the effect of ambient temperatures must be discussed. In the first week when test cells were facing south, ambient weather ranged between $18.3^{\circ} \mathrm{C}$ and $35.6^{\circ} \mathrm{C}$. In the second week with test cells facing east, colder temperatures were observed as ambient conditions varied from $15.4^{\circ} \mathrm{C}$ to $34.2^{\circ} \mathrm{C}$. Results displayed in Fig. 5.18 point to the larger impact of weather on PCM performance compared to changes in solar radiation.

As the frequency of activation shows in the south orientation, the Energain PCM layer is mainly in liquid phase due to higher temperatures while the Bio PCM layer was activated $30 \%$ of the time. In the second week, as test cells were rotated to the east, lower outdoor temperatures lead to higher activation of the Energain layer in both ceiling and wall surfaces. As the temperature ranges were mostly applicable to the Energain layer, Bio PCM layer stayed in solid phase $44 \%$ of the time. Additionally, lack of direct solar radiation in the east orientation during 
the day might have also contributed to these patterns. Pertaining to lower surface temperatures of the ceiling compared to the composite PCM wall, the solid state for the Bio PCM layer in the ceiling is higher.

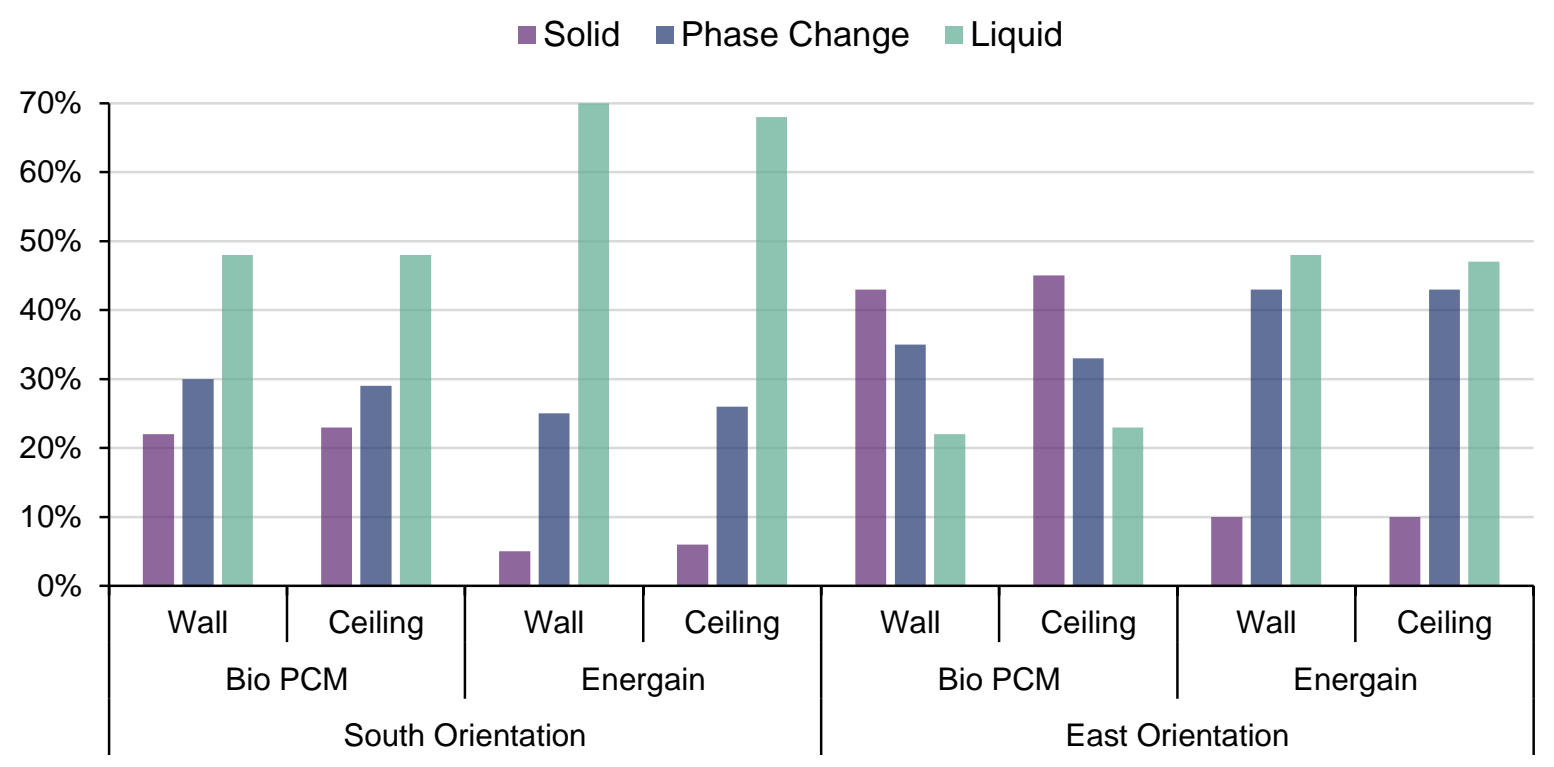

Figure 5.18- Frequency of activation for composite PCM ceiling and side wall in test \#3

Figures 5.19 and 5.20 show the hourly room (Ta) and surface temperature (Ts) variations in three consecutive days in September. Without PCM application the indoor room temperatures of the reference cell show a close proximity to the reference wall and ceiling's surface temperatures particularly in maximum peak periods during the day. Conversely considering the indoor air of the composite PCM cell and the composite PCM surface temperatures, a notable gap is observed. Even though the overall trend in both figures is very similar, the slight variation could be seen in the performance of the composite PCM system in the ceiling and walls.

Considering composite PCM wall and ceiling surfaces, their average surface temperatures are 4 ${ }^{\circ} \mathrm{C}$ lower than the indoor cell temperatures. The largest temperature difference between the composite PCM surfaces and their corresponding cell air temperature is reached on high peaks during the day. Whereas during the night, the surface temperatures get closer to the indoor room temperature as a result of heat release. Opposite behavior occurs in the reference test cell, at night the reference surface temperatures are lower than the room temperatures and lose heat rapidly. This is a clear indication of heat loss in the night hours while the radiant heat impact of the composite PCM is evident by keeping the air and surface temperatures approximately in the same range.

The gap between the composite PCM surface and room temperature is decreased during the night period, on the contrary, as early as 7 am with availability of solar radiation, this difference starts to rise. The room quickly starts to warm, while the surface temperatures are increased incrementally as a result of heat storage in the PCMs in the walls and ceiling that eliminates rapid thermal excitations the surfaces. 


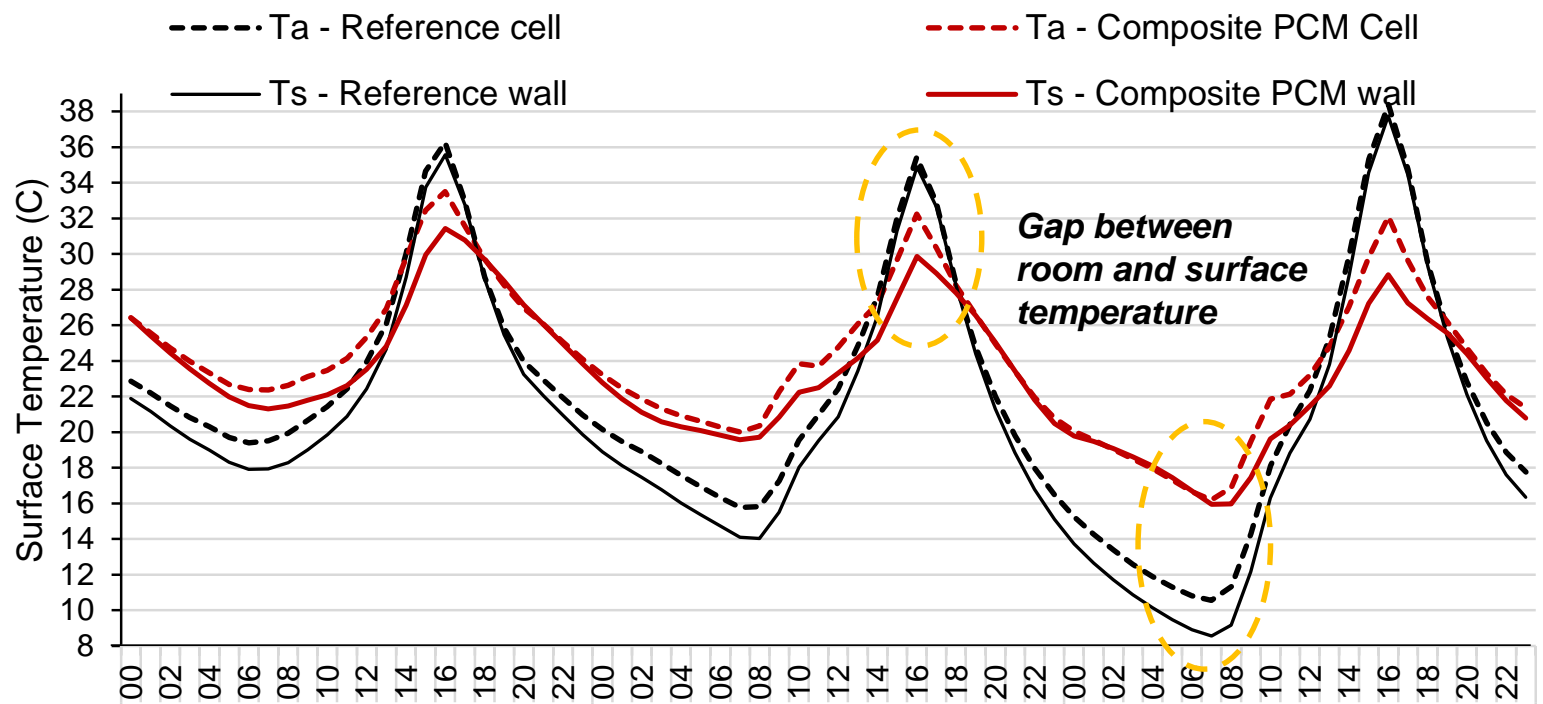
$10 / 09 / 2016$
$11 / 09 / 2016$
$12 / 09 / 2016$

Figure 5.19- Hourly Indoor Room temperature and Side wall surface temperature variations

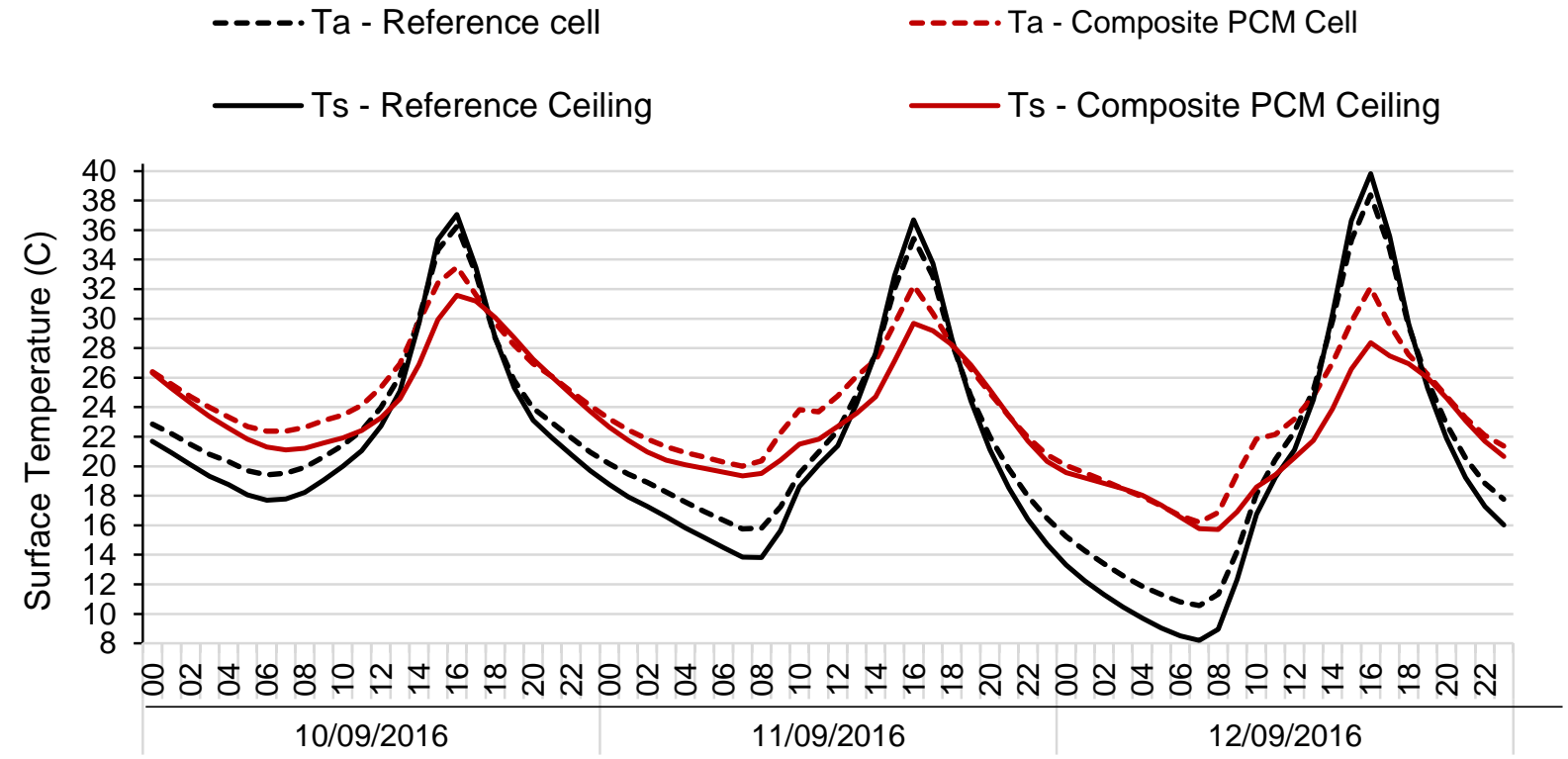

Figure 5.20- Hourly Indoor Room Temperature and Ceiling surface temperature variations

\subsubsection{Test \#4 - Testing the impact of shading and Natural ventilation}

Test cells are modified and the shading parts of the cells are removed. The same wall and ceiling as test \#3 are tested. The main variable of this test is shading to further assess the influence of solar radiation on PCM performance compared to the shaded situation by examining direct solar access to the cells. Moreover, as the indoor temperatures are expected to rise with no shading, natural ventilation is tested to check the potential of night cooling on heat release/storage process of the composite PCM system. 
Test \#4 is performed from September $24^{\text {th }}$ to October $12^{\text {th }}$ while the test cells face the south. Colder ambient conditions during this period led to a change of behavior in the composite PCM system. Average ambient conditions varied between 10 to $22^{\circ} \mathrm{C}$ with a full overcast period of 10 consecutive days with no solar radiation available.

Similar to previous results, the reference test cell is highly dependant on outdoor weather conditions ultimately leading to average colder indoor temperatures. Whereas in the composite PCM test cell, due to increased thermal inertia and storage capacity, indoor air temperatures are kept constantly above outdoor temperatures. On all days in this period, indoor temperatures of the composite PCM cell are higher than the reference cell even in high peak periods. This could be a direct relation to the greater solar availability in the cells, however, another factor is the colder ambient temperatures in this period affecting the large gap between the cells.

Comparing the average room temperatures and rate of change caused by the composite PCM surfaces with and without shading is presented in Figure 5.21. Removing the shading does not positively affect the PCMs' ability in reducing excessive heat gain in the spaces. In the no shading scenario, the reduction of high peak indoor temperatures in the composite PCM test cell is only $1 \%$. By removing the shading, the increase of low peak temperatures at night is $20 \%$ higher than when the composite PCM test cell is shaded. This suggests that excessive solar gain in the cells degrades the performance of the composite PCM, however more accurate results in one similar ambient conditions while testing the shading could show different results.

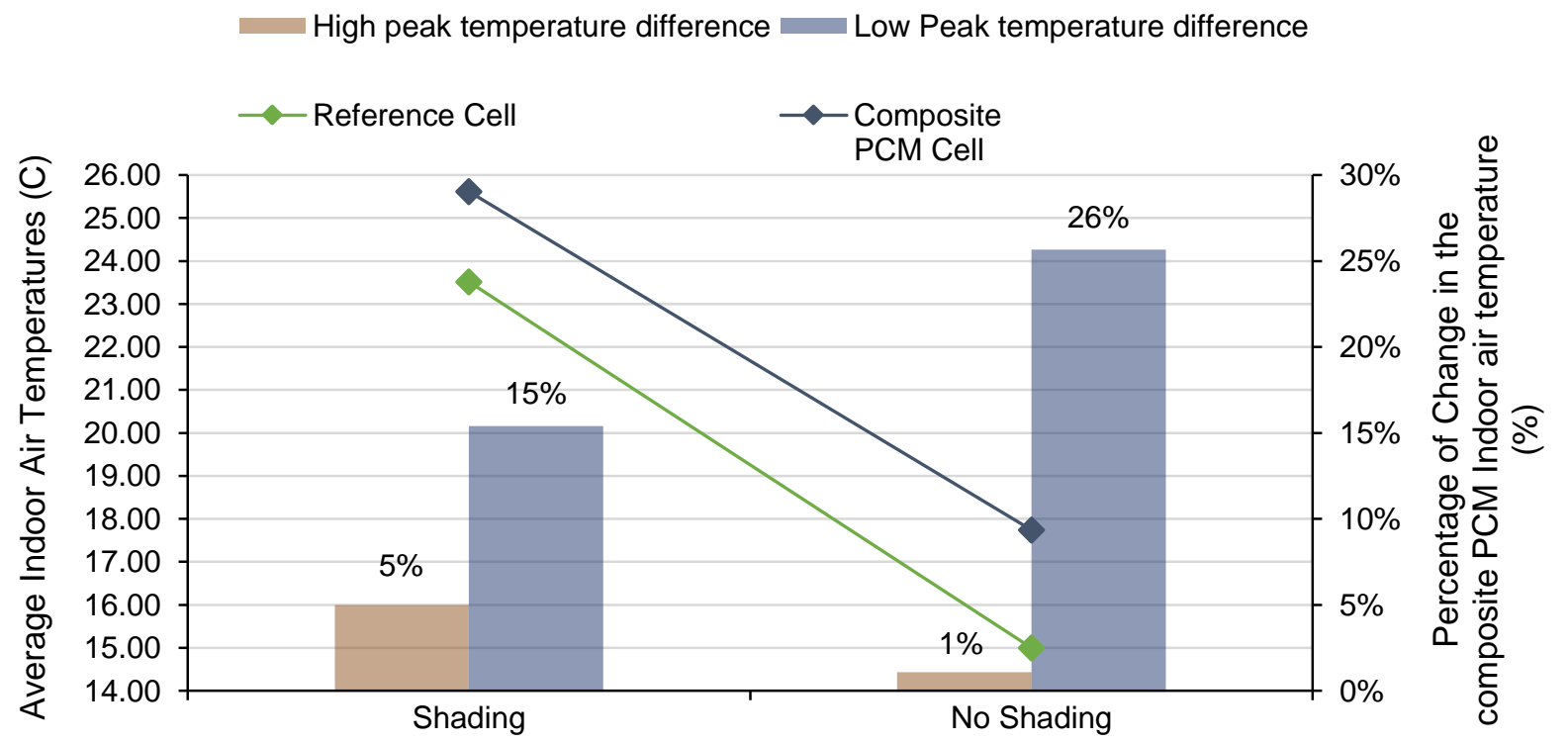

Figure 5.21- Correlation of indoor temperature changes with and without shading

A typical day in test period \#4 (no shading) with a daily outdoor temperature variation between 7 to $22.6^{\circ} \mathrm{C}$ in October and a typical September day in period \#3 (with shading) with outdoor temperatures between 11.4 and $37.6^{\circ} \mathrm{C}$ are compared. It should be noted that the sunshine period in October is 1 hour 30 minutes shorter than in September, thus less exposure to solar radiation is available. Even though in October days both temperatures and solar intensity are lower in the cells, indoor air temperatures of the composite PCM test cell rise to $32.6^{\circ} \mathrm{C}$ during the day. In the September day, however, the highest indoor air temperature recorded is $31.6^{\circ} \mathrm{C}$. 
Hourly ambient temperature variations in both September and October days occur gradually with an average $0.1^{\circ} \mathrm{C}$ change. Considering the rate of indoor air change in the composite PCM test cell in September with available shading, similar gradual temperature increase could be seen. Indoor temperatures in the composite PCM test cell rise slowly and reach the melting range of both PCM products in a 4-hour period. In contrast, on the October day in test \#4 with no shading, indoor air temperatures in the composite PCM test cell rises by $11^{\circ} \mathrm{C}$ from 17 to 28 ${ }^{\circ} \mathrm{C}$ at the peak of solar radiation in the south orientation. This sharp increase in the indoor air of the test cell leads to melting of both PCM layers in only one hour which moves to sensible gain after they are melted further increasing indoor temperatures. This is directly linked to solar radiation and the role of shading in controlling exposure.

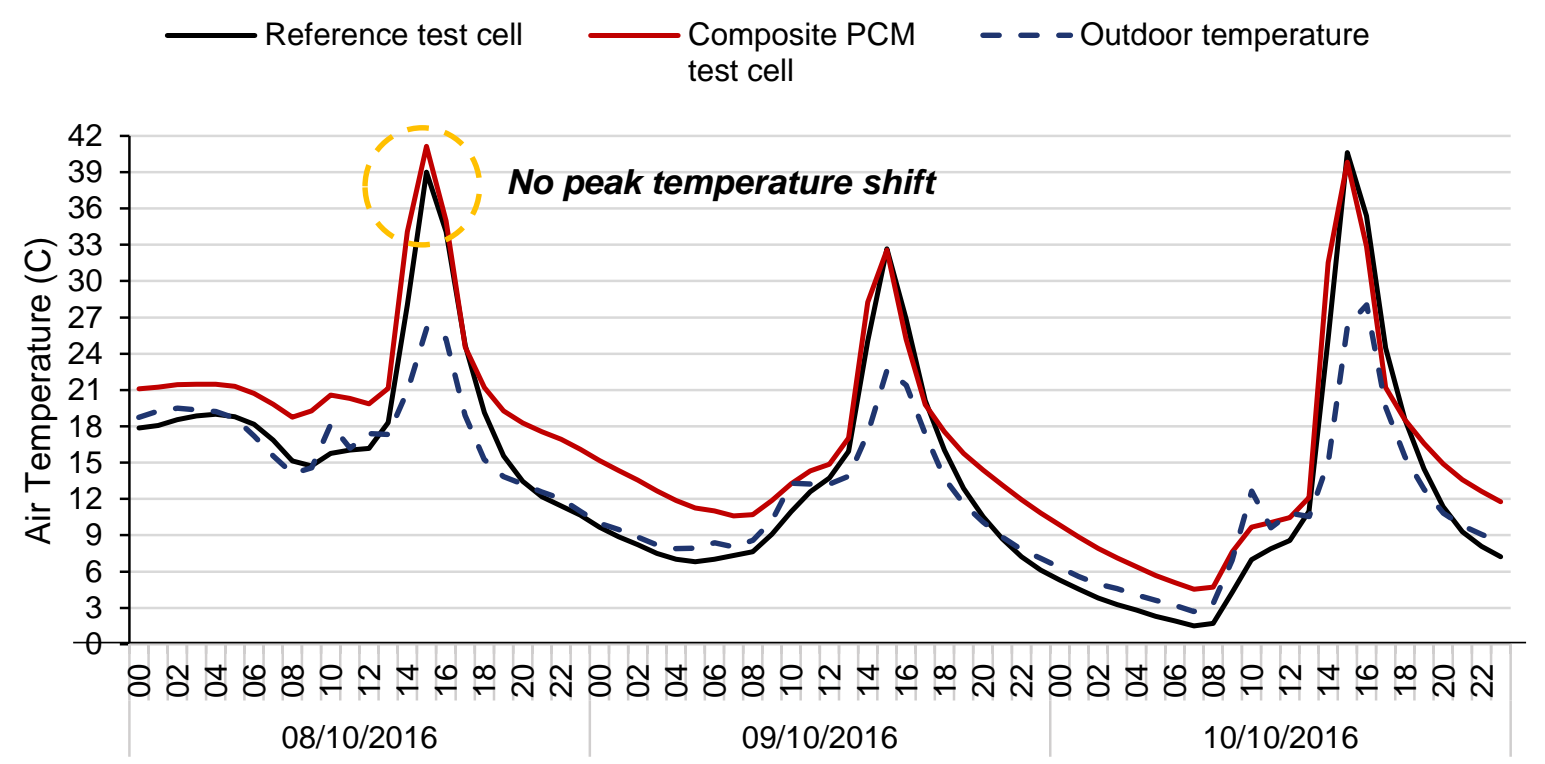

Figure 5.22- Hourly indoor room temperature variations from October $8^{\text {th }}-10^{\text {th }}$ - Test $\# 4$

In conclusion, the primary difference between the shaded and not shaded scenario is that by removing the shading the effect of solar radiation is visible in a specific period with sharp temperature rise in both test cells. A spot effect which causes the PCMs to melt quite fast and as the excessive heat exceeds the latent heat storage capacity of the PCMs their temperatures rise through sensible storage. This effect will be discussed in more detail in section 5.2.5.

Pertaining to the results, it is suggested that the influence of ambient weather conditions is more prominent than the direct solar gain in the cells, as temperature variations control the entire transition of the composite PCM systems during the day and night. Whereas solar radiation only affects specific periods and complements the ambient temperatures in influencing the phase change process. In addition, considering the first half of testing period \#4, with full rainy days, shows that the composite PCM system still works regardless of direct solar radiation.

One outcome of using the composite PCM is peak temperature shifting discussed in test \#1. This peak shifting as shown in Figure 5.22 does not occur during test \#4 and both test cells reach the high peak points at the same time. This graph shows a sharp temperature increase in the composite PCM cell of nearly $20^{\circ} \mathrm{C}$ as the indoor room temperatures reach the threshold of melting range of the Bio PCM at $1 \mathrm{pm}$ on these days. This factor is due to shorter sunshine 
period in the day compared to tests conducted in summer months. The longer period of sunshine hours entails a longer melting period in which the indoor temperatures are constant leading to a peak temperature shift. In contrast to fall months with lower sunshine hours and sharp ambient variations, the constant period achieved by PCMs is shorter.

Higher exposure to solar radiation without shading results in higher night temperatures in the composite PCM test cell which also affects room temperatures in the next cycle. However, lower specific heat values in the reference cell entail a slower heat gain and temperature rise in this cell as the temperatures are already quite low. Thus, a large difference exists between the two test cells on mornings.

\section{Natural ventilation}

Natural ventilation was added on two separate nights in October in test \#4. A $2 \mathrm{~cm}$ opening in the top part of the test cells was created to allow for airflow. Figure 5.23 shows the wall surface temperature variations for the same three days shown in Figure 5.22. Night ventilation was applied on October $9^{\text {th }}$ for 10 hours until 7:30 am on October $10^{\text {th }}$. The benefit of using natural ventilation is evident on reducing the high surface peak temperatures on October $10^{\text {th }}$. This is a reduction of maximum temperatures up to $7.8^{\circ} \mathrm{C}$ in the composite PCM wall from the peak in the reference wall. This value is $3.4^{\circ} \mathrm{C}$ more than the same change perceived on $8^{\text {th }}$ and $9^{\text {th }}$ considering a similar trend of surface temperature variation.

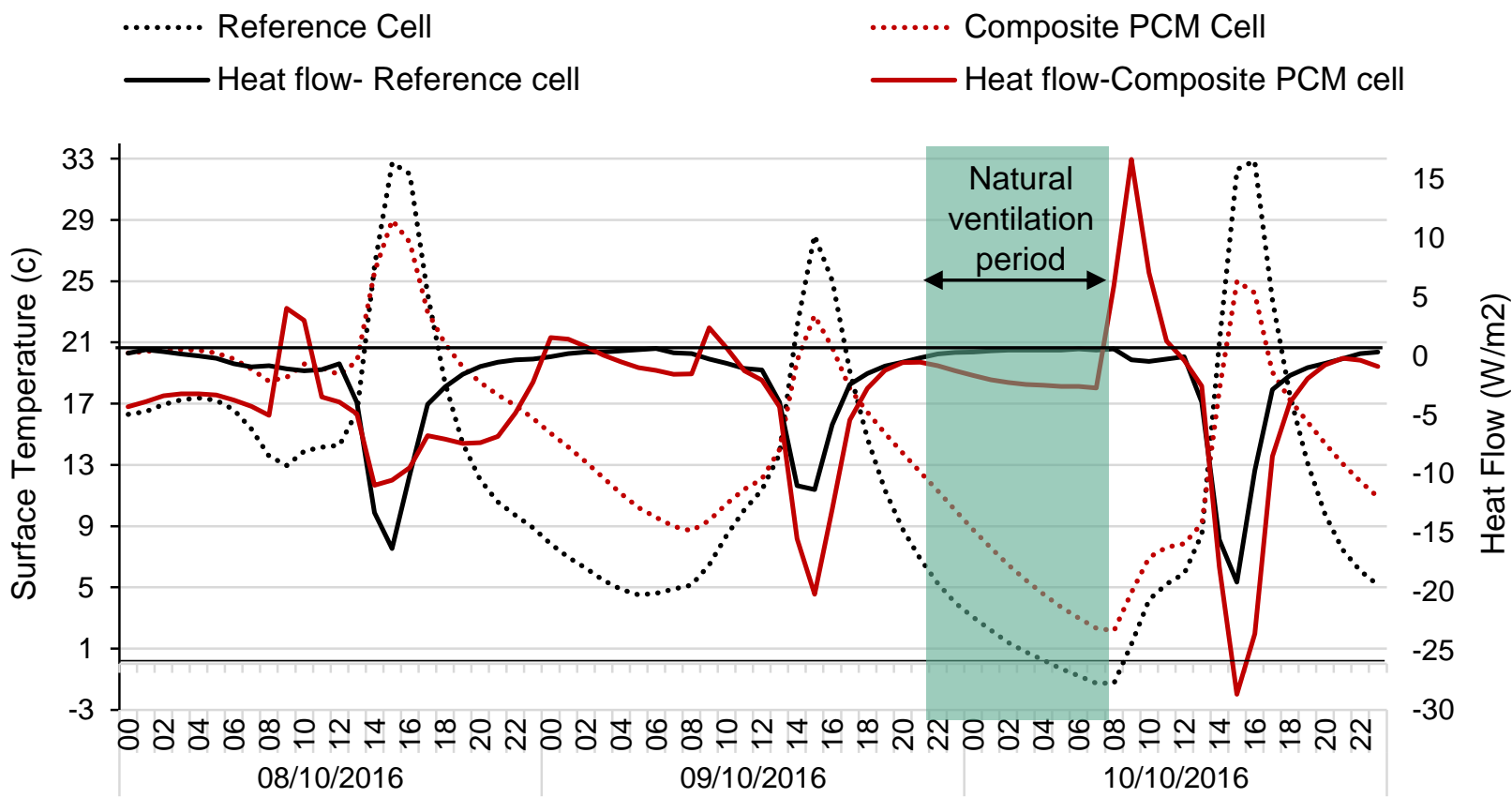

Figure 5.23- Hourly surface temperature and heat flow in the cells from October $8^{\text {th }}-10^{\text {th }}$

The heat flow graphs demonstrate the impact of natural ventilation in reducing the surface temperatures well below the melting range of both PCM products. This low temperature experienced at night results in the highest heat release from the wall to the room at 9 am on October $10^{\text {th }}$. Temperatures on prior nights are also lower than the required solidification range 
of both PCMs. Yet it seems that by accelerating this process through natural ventilation, the heat absorption process in the coming days is enhanced. The results obtained from Test \#1 and Test \#2 show that higher night temperatures delay the solidification process of the composite PCM layers to early morning periods to even after sunshine hours. However, in this test by including the natural ventilation to the test cell, a faster solidification and heat loss from the surfaces occurred that could show potential improvements in the summer period as well in reducing the recharge time for this composite PCM system.

\section{Surface analysis}

The impact of solar gain on the monitored ceiling and wall in shaded and not shaded situations is assessed. The basis of comparison is the influence of room indoor temperature on each surface and the average, maximum and minimum surface temperature changes. A primary assessment between Figures 5.22 and 5.23 points to a significant difference between the pattern of change in the composite PCM wall surface temperatures and the indoor room temperatures of the composite PCM cell. Particularly in reducing excessive heat gain, the wall surfaces show a considerable decrease while the peak room temperatures are not reduced.

As testing periods \#3 and \#4 are one month apart, the average surface temperatures also vary. In the presence of shading the surface temperatures are closer to the indoor room temperatures in both test cells. Whereas by removing the shading, the average surface wall and ceiling surface temperatures in the cells are $2.2^{\circ} \mathrm{C}$ below the room air temperatures. As the shading is removed, the excessive heat gain projected to the rooms considerably raises the cell temperatures resulting in a significant gap between the room and surface temperature values. In peak heat gain periods, the maximum room temperatures in the composite PCM test cell are 11 ${ }^{\circ} \mathrm{C}$ higher than the wall or ceiling surface temperatures. This gap in the shaded scenario is $2{ }^{\circ} \mathrm{C}$ between the maximum surface and the room temperatures in this cell.

Comparing the ceiling and the side wall in the not shaded scenario it is observed that the composite PCM in the ceiling is more effective in lowering the maximum surface temperatures by $8.1^{\circ} \mathrm{C}$ compared to the reference ceiling. The composite PCM ceiling is significantly more effective in decreasing high peak heat gain temperatures, this is consistent with previous results of Test \#3.

It is inferred from the analysis that by removing the shading, the effectiveness of the composite PCM's radiant heat is declined in affecting the room air temperatures. One of the factors observed in test \#4 in comparison to test \#3 is the rate of incremental temperature changes in a composite PCM surface after the melting point is reached. For instance, when the melting threshold of the Bio PCM is reached in test \#3 in the wall and the PCM is fully melted, the sensible temperature rise in the next hour is $2.6^{\circ} \mathrm{C}$. In test \#4 however, the Bio PCM melting range is rarely reached while the same analysis for the Energain layer shows that after the PCM is melted the hourly temperature rise is $6.3^{\circ} \mathrm{C}$.

A further investigation of the surfaces by analyzing frequency of activation for the PCM products in both shaded and not shaded situations points to the substantial impact of temperature changes in these two periods on the rate of PCM activation. Higher indoor temperatures in test period \#3 show a longer period in which the PCMs are melted, specially Energain PCM. While the largest percentage of phase change process is allocated to the Bio PCM in both ceiling and 
wall surfaces, the Energain stays liquid for nearly $68 \%$ of the time. In contrast, colder weather patterns experienced in test \#4 led to a longer period in which the PCMs stayed solid. The activation of the Bio PCM product in this test is only $6 \%$ on both surfaces compared to the $30 \%$ activation in test \#3 show a significant performance decline. Energain PCM is activated $31 \%$ of the time in test \#4, indicating the larger impact of this PCM layer in colder periods.

\subsubsection{Test \#5 - Testing individual PCM products}

This test was performed for eleven days from August $27^{\text {th }}$ to September $6^{\text {th }}$. The aim is to separate the PCM products used in the composite PCM application to assess their performance individually. Thus, the walls of one test cell are lined with Energain PCM and the other test cell with Bio PCM. The configuration is shown in Figure 5.24. In this analysis, only the side wall is monitored with sensors positioned in between all layers.

The average ambient temperature is $25^{\circ} \mathrm{C}$ in this period. Average indoor room temperatures of the Bio PCM test cell is $1.9^{\circ} \mathrm{C}$ higher than the air temperatures of Energain test cell. However, during the day the Energain test cell experience higher maximum temperatures, $1.2{ }^{\circ} \mathrm{C}$ more than the maximum air temperatures in the Bio PCM test cell.

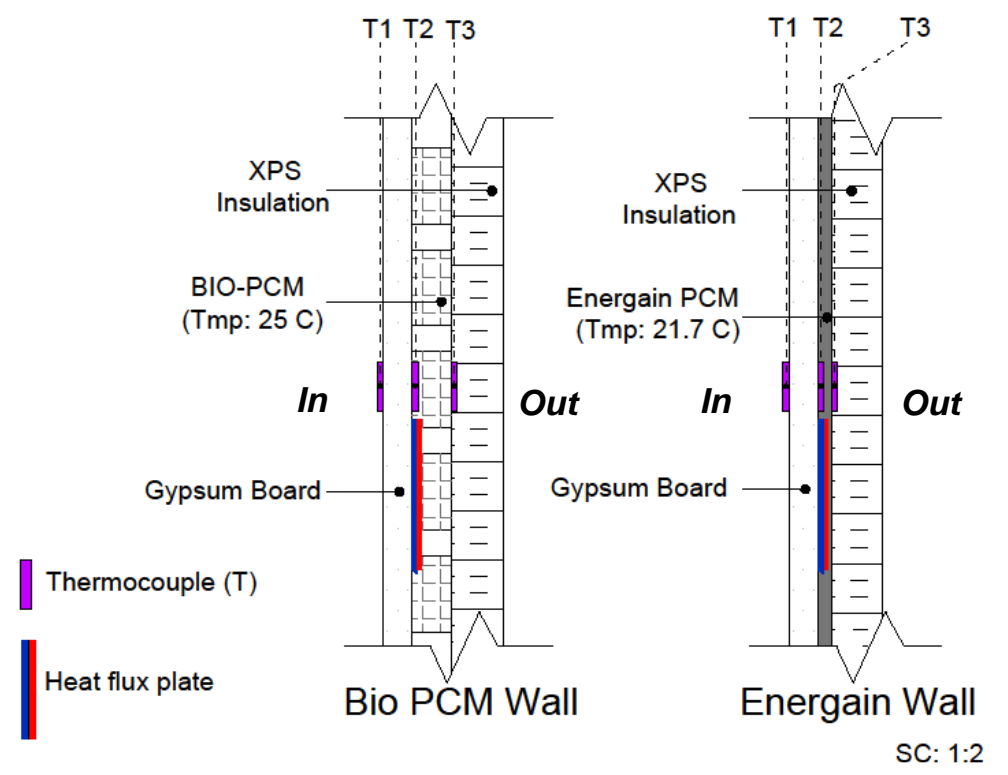

Figure 5.24. Individual PCM placements in one side wall in test \#5

As shown in Figure 5.25 overall cell temperatures during the night in both test cells are higher than the ambient temperatures. This shows that both PCMs are capable of moderating night temperatures individually when they start to solidify in their melting range. Evidently, due to different melting ranges Bio PCM test cell's night air temperatures are above the Energain test cell. One reason for the higher peak temperature in the Energain test cell could be related to the fact that in this test cell Energain is not applied to the ceiling and is only applied to walls. As discussed in test \#3, PCMs integrated into the ceiling surface store a considerable amount of heat with a higher rate of change compared to a PCM wall surface. Another reason for higher 
peak temperatures in the Energain test cell could be due to the higher specific heat of this product leading to higher sensible storage in the surfaces.

Detailed surface temperature and heat flow graphs presented in Figure 5.26 demonstrate a similar pattern and trend of change in heat flow and surface temperatures in both Energain and Bio PCM walls. The rate of heat release is $43 \%$ higher in the Bio PCM wall while the rate of heat absorption in both surfaces is quite similar. The higher heat discharge observed in the Bio PCM wall could be a due the conductivity of the Bio PCM which is marginally higher than the conductivity of the Energain PCM.

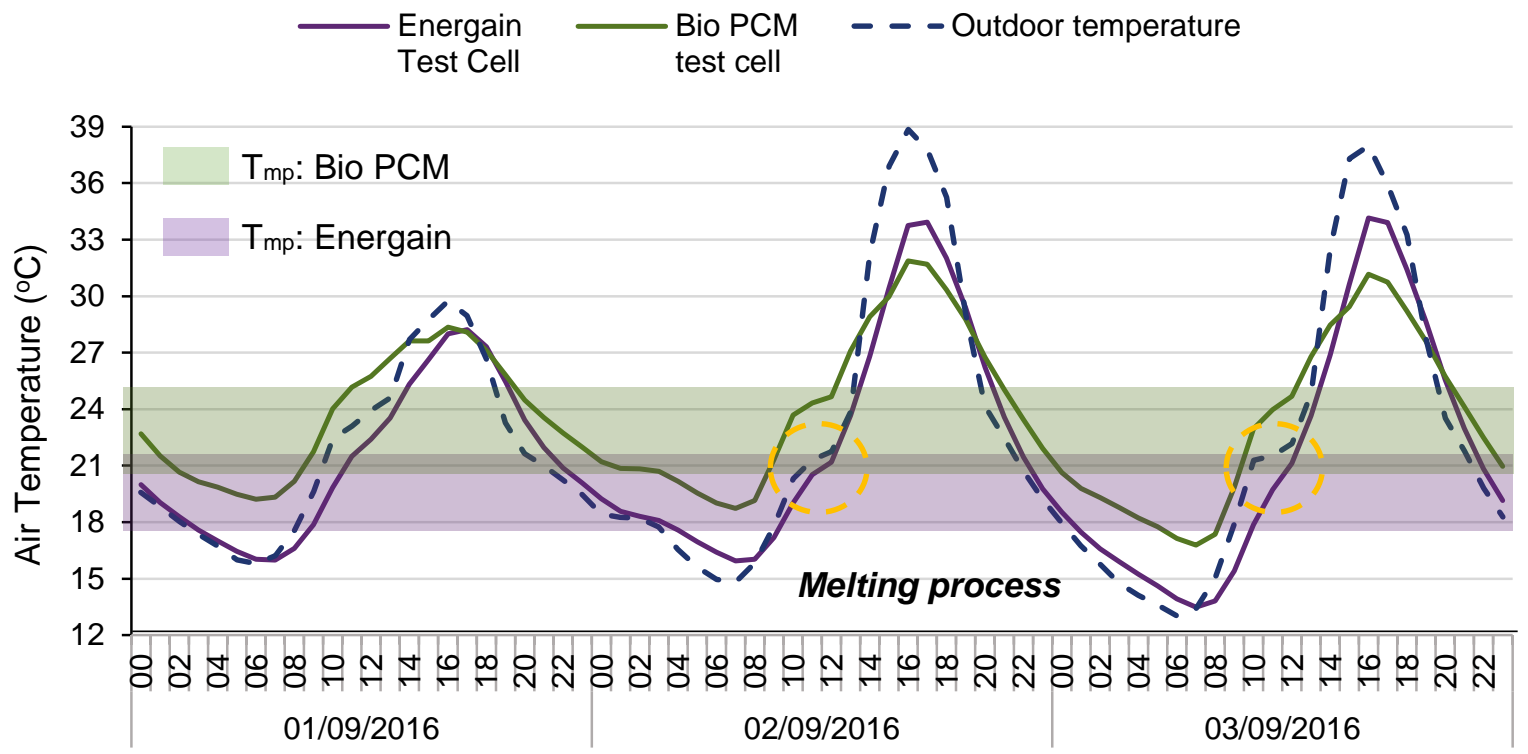

Figure 5.25- Hourly Indoor temperature changes from September $1^{\text {st }} 3^{\text {rd }}$

Due to the isothermal effect of PCMs, they maintain the surrounding temperatures within their melting range. This is evident in both the surface and indoor temperature graphs presented. A time difference for the melting and solidification was expected in each cell, for instance, an earlier melting and solidification was expected in the Energain surfaces as their melting range is from $18-22^{\circ} \mathrm{C}$. This is not the case as each test cell has an average temperature profile corresponding to the PCM integrated to its surfaces.

For a better illustration of daily fluctuations, temperature changes per minute are assessed on the first three days of September. Starting from September $1^{\text {st }}$, total daylight period is reduced to 13 hours starting from 6:45 am to 7:50 pm. Bio PCM layer starts to melt on these three days at approximately $10 \mathrm{am}, 1$ hour ahead of the Energain layer in the other test cell. The overall melting process of the Energain board is shorter than the Bio PCM, whereas the solidification process of Bio PCM on average in these three days takes only two hours. 


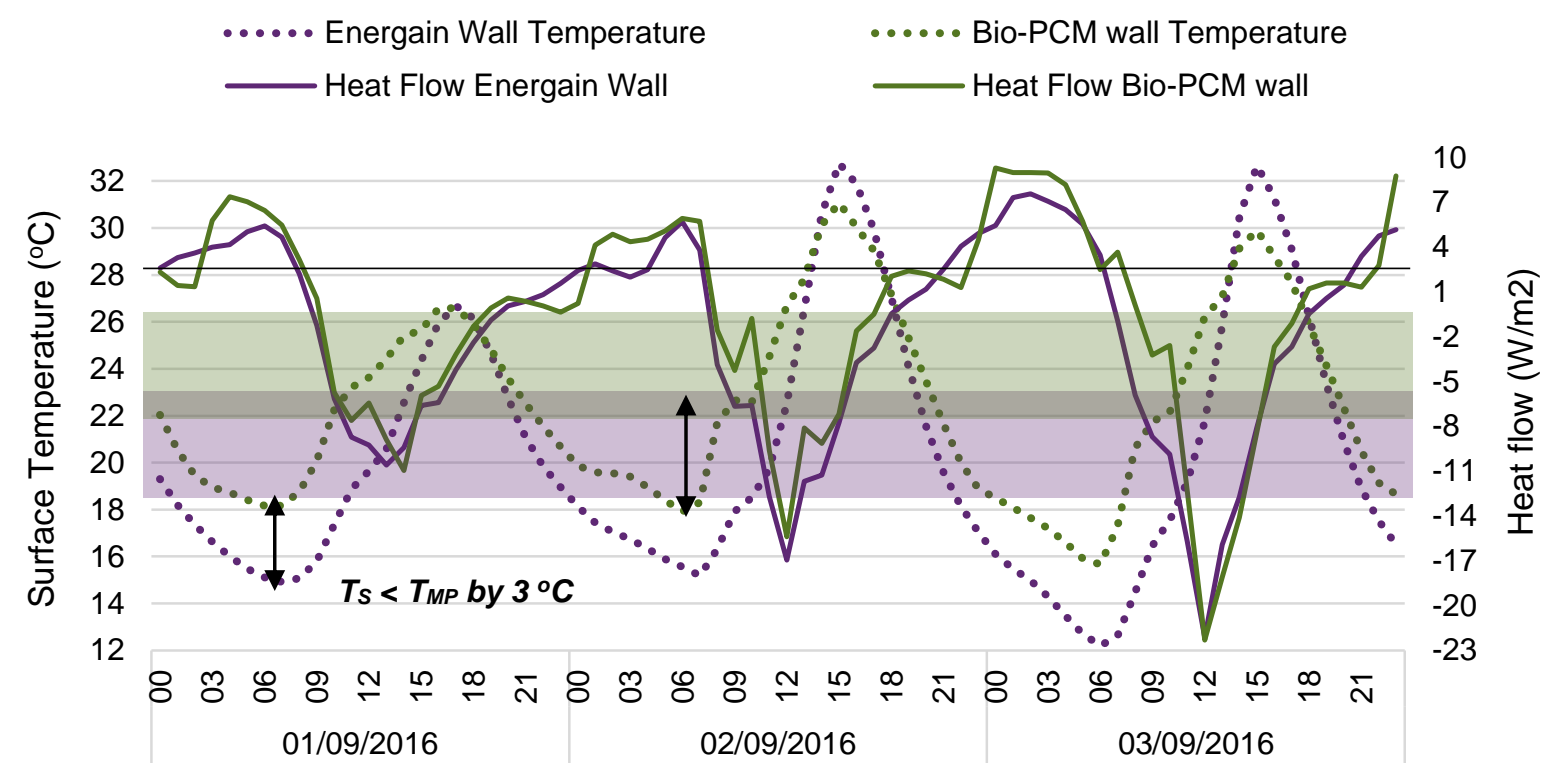

Figure 5.26- Surface temperature and heat flow variations in the side wall

After PCMs are fully melted, they are expected to undergo sensible heat storage or heat release depending on temperature variations. Considering the time frame between the fully melted state of PCMs and the start of solidification point, the overall rate of temperature increase in the Energain wall is considerably higher than the Bio PCM wall. For instance, on September $2^{\text {nd }}$ after both PCMs are melted at 2 pm, both Bio PCM and Energain side wall temperature reach $29^{\circ} \mathrm{C}$ at 3:44 pm. This considerable rise of temperature directly shows the impact of higher specific heat in Energain wall. In a period of 1: 45 hour, the Energain's wall surface is increased from 22 to $29^{\circ} \mathrm{C}$ whereas the Bio PCM wall reaches the $29^{\circ} \mathrm{C}$ with a rise of only $4{ }^{\circ} \mathrm{C}$ in its surface temperature. A similar observation is made in the solidification process after the PCMs are considered fully solidified. The coldest temperature experienced on the Bio PCM wall after it solidifies at $10 \mathrm{pm}$ on the $2^{\text {nd }}$ is $15.5^{\circ} \mathrm{C}$. In contrast, from $9 \mathrm{pm}$ on the $2^{\text {nd }}$ to the start of the next melting cycle, the Energain wall experiences an extreme temperature variation as the temperatures drop as low as $12^{\circ} \mathrm{C}$.

During the isothermal process of melting, however, the rate of surface temperature is slowed down as expected. During the melting of Bio PCM, the surface temperature of this wall is fixed at $22{ }^{\circ} \mathrm{C}$ from 10:16 am to $12: 37 \mathrm{pm}$. In the Energain, however, the process takes less time, thus shorter constant period for the surface temperatures. Nevertheless, on the same day as the Energain melts, surface temperatures are fixed to $18 \mathrm{C}$ from 11:10 am to $12: 48 \mathrm{pm}$. In general, considering the entire melting range of each PCM layer, the constant period for each temperature point is approximately 30 minutes.

Another main factor observed is the time lag caused by the PCMs. Even though this could be a positive factor specifically for peak temperature shifting and maintaining constant temperatures for longer periods, the time frame of the solidification period and sunshine hours may not match. For instance, in both test cells at night, air temperatures start to decrease rapidly in the room from $7 \mathrm{pm}$, but in August nights, the Energain wall reaches $18^{\circ} \mathrm{C}$ in early morning at $7 \mathrm{am}$. This factor is reduced completely in September days as temperatures are cooler. 
A linear correlation is found between wall surface temperatures and indoor room temperatures as presented in Figure 5.27. The difference between room and surface temperatures shows the time lag needed for the surfaces to reach the desired melting points to either melt or solidify. On average in the three days of September $1^{\text {st }}-3^{\text {rd }}$, the gap between indoor air and surface temperatures in Energain cell are more than the gap observed in the Bio PCM cell. In general, the room air temperatures, directly linked with ambient temperature changes start to rise in the morning, distancing from the surface temperatures until the melting point is reached. This difference is minimized during the phase transition, minimizing the gap between the two.

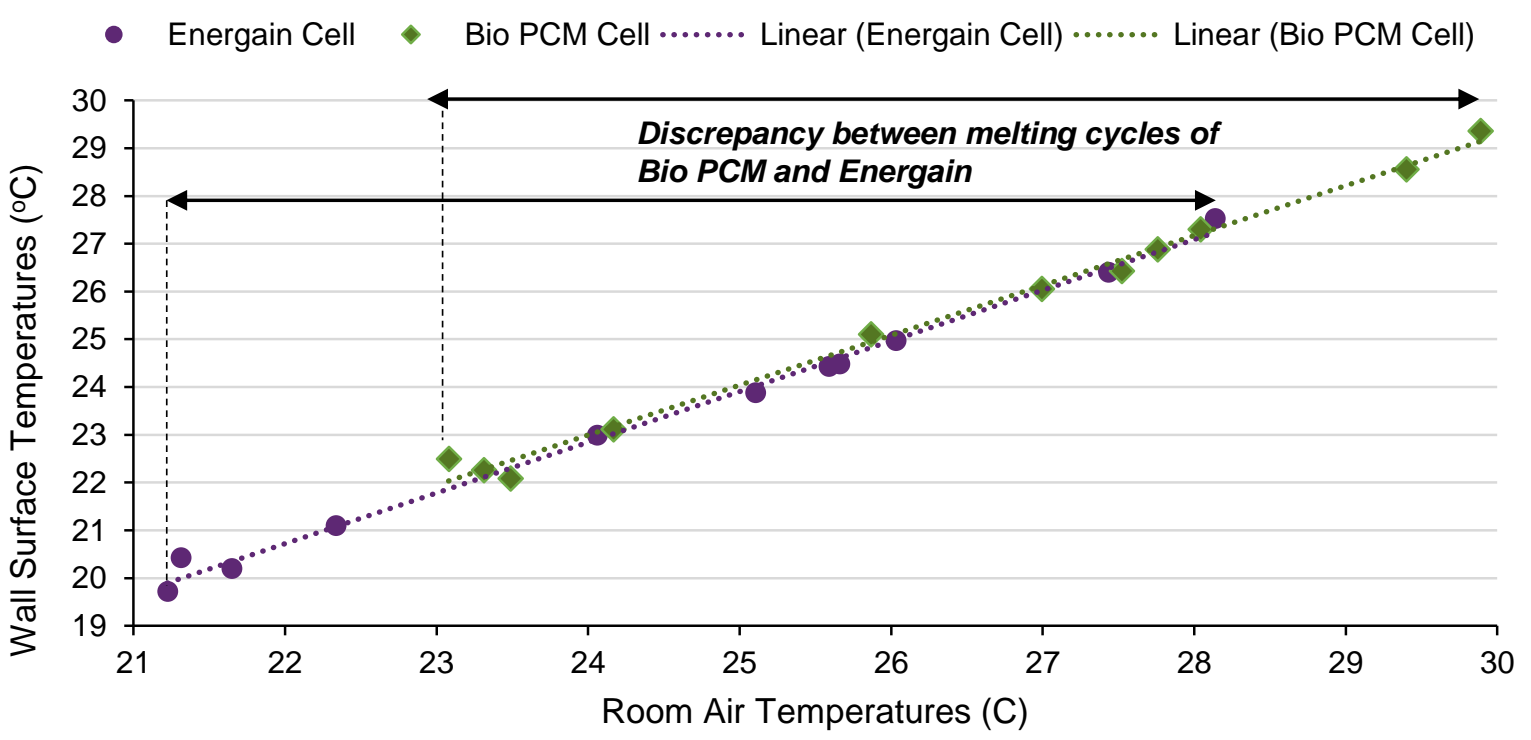

Figure 5.27- Correlation of average indoor air and surface temperatures in each test cell

The radiant heat transfer of the walls is visible during the night as wall surface temperatures are lower than the room air temperatures indicating the radiant heat release to the cell. Only after the PCM surfaces are melted and undergoing sensible heat gain, a higher surface temperatures compared to air temperatures is recorded.

Figures 5.28 and 5.29 represent the measured surface temperatures across three layers in each PCM wall with heat flow variations. It should be restated that the heat flow as all the previous tests is measured between the PCM layer and gypsum board. The maximum temperature and the maximum heat gain, as well as minimum temperature and maximum heat loss, clearly occur at the same period. Recorded temperature differences in the sensors positioned between all the wall layers show a negligible difference between temperatures at the front and back of the Energain PCM product.

However, in Figure 5.29 the drywall's surface temperature and the first layer's surface temperature are more aligned while the back of the Bio PCM perceived more irregular changes during the day. Moreover, the overall temperature profile shows that the Bio PCM temperatures are more sustained and limited to its temperature range, with $16{ }^{\circ} \mathrm{C}$ temperature swing in one day, while this swing is $20^{\circ} \mathrm{C}$ in the Energain PCM. 


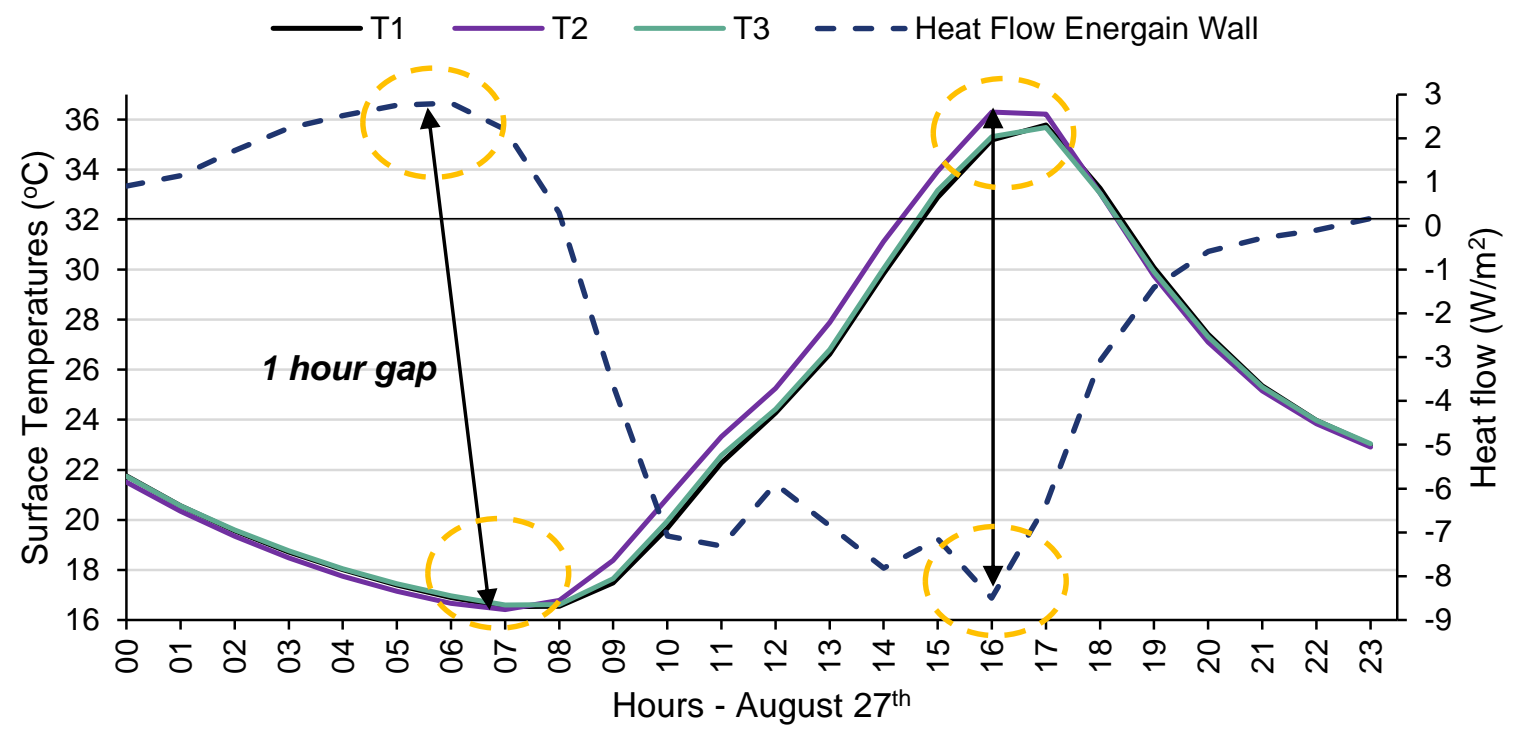

Figure 5.28- Inner wall layer temperature and heat flow in the Energain cell -August $27^{\text {th }}$

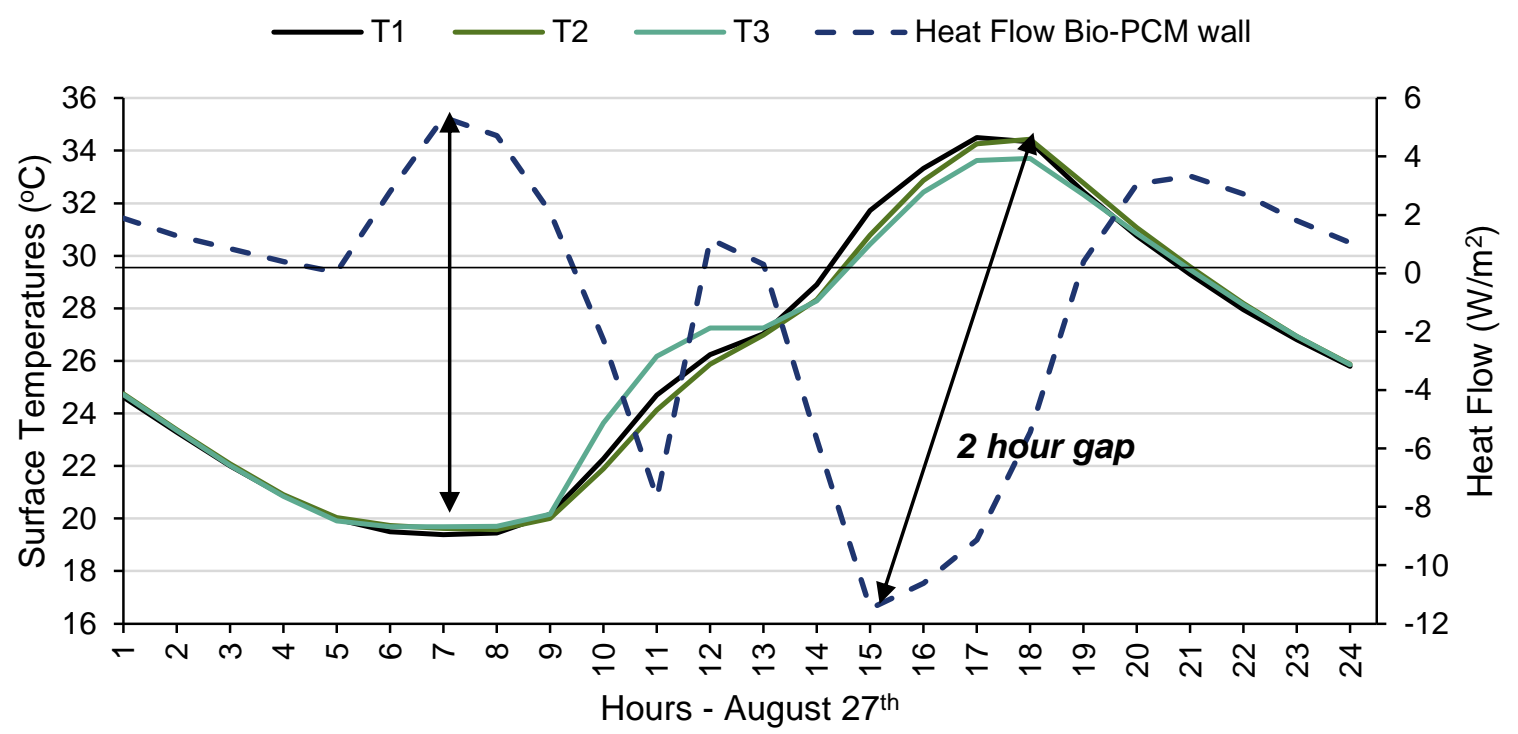

Figure 5.29- Inner wall layer temperature and heat flow in the Bio PCM cell -August $27^{\text {th }}$

The heat flow changes evidently show the higher heat gain rates in both walls on average by $69 \%$ compared to overall heat release to the space by both PCM products. As soon as the PCMs start to melt the heat flow values also change to negative indicating heat gain in the walls. Regarding the solidification process, both walls reach their peak heat release values when the surface temperatures are cooled down by $3^{\circ} \mathrm{C}$ below their minimum threshold of melting range (Figure 5.26). For instance, the minimum temperature of Energain wall which is synonymous with the highest heat release to the space is $15^{\circ} \mathrm{C}$, which is $3^{\circ} \mathrm{C}$ lower than $18^{\circ} \mathrm{C}$ the lowest threshold of freezing point for this product. The same trend is visible for Bio PCM, where the minimum temperatures and highest heat release occur at $18^{\circ} \mathrm{C}$ surface temperature. 


\subsubsection{Overview}

The overall impact of the composite PCMs demonstrates constant temperatures for longer periods, and slower transition times which resulted in peak shifting and reduction of extreme temperatures. The experimental tests show that the proposed composite PCM system could easily be activated in passive conditions when the cells are only exposed to solar radiation and ambient weather. Another positive outcome of this research proved that longer testing period is beneficial in showing how the PCMs' behavior changes with ambient temperature fluctuations. Specifically, as the proposed composite PCM system in this study is intended to perform in diverse yearly temperature variations.

The capability of this system is clearly displayed as each PCM targets the fall and summer months as expected, Energain layer addresses the temperature range of fall months while the Bio PCM is effective in reducing overheating in July and August. The composite PCM system undergoes one full cycle each day. This diurnal cycle consists of one full melting cycle in the day and a solidification cycle at night in the case of favorable low ambient temperatures.

Key results derived from the experimental tests:

- The main outcome of implementing the composite PCM to surfaces is the significant reduction in the vulnerability of the composite PCM test cell to ambient weather changes.

- Implementing natural ventilation at night is beneficial in accelerating the solidification process and leading to an earlier solidification before sunrise hours. However, more detailed analysis is required by measuring the amount of heat flow and time of exposure to find the most effective natural ventilation scenario for the effective discharge of PCMs.

- Comparison between ceiling and wall surfaces integrated with PCM showed a higher percentage of heat absorption in the ceiling compared to the composite PCM wall.

- With increased resistance of the enclosure by applying the composite PCM system, air temperatures are kept longer in the cell, in addition to the release of the stored energy from the PCM surfaces to the room which moderates the night temperatures.

- Observing the changes in the composite PCM side wall and window facing wall shows that the window facing wall experiences higher average temperatures, however, the impact of PCM is also marginally more in this wall than the side wall.

- The impact of PCMs in reducing high and low peak temperatures is higher in extreme conditions with sharp temperature changes.

\section{Relation of solar radiation and ambient weather on PCM performance}

The initial research focus in this study is regarding the impact of solar gain on PCM performance considering different orientations. The final consequence from the experimental tests is that the effect of ambient weather variations is the main driving factor for full PCM activation. Nevertheless, exposure to solar radiation enhances the melting process. The influence of solar radiation is periodical specifically at times of highest solar intensity yet this effect is not constant. 
Moreover, the number of sunshine hours was observed to be linked to the peak temperature shifting caused by PCMs. Comparing the indoor air temperature of the reference test cell and the composite PCM test cell a peak shifting in time could be seen for maximum temperatures. As the sunshine hours become shorter from July to October, the effect of the composite PCM in shifting maximum air temperatures in the cell also decreases due to shorter time for the melting of PCMs. In July and August days, an apparent peak shifting of at least one hour takes place.

Regarding different orientations, the experimental tests could not draw a direct link between the impact of solar gains from each direction as ambient conditions in each week when orientation was tested varied. The highest and sharpest fluctuations were experienced when the test cells were rotated to the west and furthermore high-peak temperatures in both cells coincided with the peak solar times. The behavior of composite PCM system in performing the phase transition and heat storage is more constant when test cells are facing the south.

Referring to previous studies done by Liu (1993) and Muruganantham (2010) which performed experimental tests in mechanically conditioned test cells shows that the effect of solar radiation becomes more prominent when the room has a constant temperature through active mechanical space conditioning. In contrast to this study which is conducted under passive conditions where outdoor temperatures are the primary driving factor for PCM activation.

Another parameter to assess the solar radiation's relation to PCMs was testing the effect of shading. Removing the shading even though occurred in colder month of October decreased the effect of the composite PCM system in reducing overheating. In contrast, higher average temperatures in the composite PCM test cell without shading led to higher night temperatures. Excess heat being exposed to the cells causes fast melting of PCMs. This excessive heat surpasses the latent heat storage capacity of the composite PCM system which turns into sensible temperature rise.

Thus, a direct link exists between sensible temperature rise and higher solar gains in the units. Finally, the availability of solar radiation is more important in fall months due to lower temperatures to ensure activation of the PCMs. Whereas in summer, the excessive heat could lead to a longer period in which the PCMs stay melted, thus having a shading would be beneficial. To better explain the impact of ambient weather on PCM performance, average data in each testing period in the span of four months are compared. The basis of this comparison is to identify by how much rate of change in outdoor conditions, the effectiveness of the composite PCM changes. Table 5.7 summarizes different parameters in each testing period where the test cells are facing the south orientation and the wall surface temperatures are recorded.

By looking at the trend of outdoor temperature variations and the PCM activation, the highest percentage of PCM's being activated is recorded in the month of July. Correspondingly in this month, the composite PCM system reduces indoor temperature swings and high peak temperatures significantly compared to other months. The effectiveness of having a hybrid PCM system with two melting points is evident as in August and July, the Energain PCM is mostly in liquid form. In contrast, the Bio PCM is often in the solid state in September and October. The low percent of decrease in maximum temperatures in October is due to the excessive heat gain in the cell with removal of shading. The higher rate of increase in minimum temperatures in October and September is a result of full solidification due to colder nights. 
Table 5.7. Average outdoor and indoor air temperatures and the impact of composite PCM

\begin{tabular}{|c|c|c|c|c|c|c|c|c|c|}
\hline \multirow[b]{2}{*}{ Parameters } & \multirow{2}{*}{$\begin{array}{c}\text { Ambient } \\
\text { Conditions } \\
\left({ }^{\circ} \mathrm{C}\right)\end{array}$} & \multirow{2}{*}{$\begin{array}{c}\text { Daylength } \\
\text { (Sunshine } \\
\text { hours) }\end{array}$} & \multirow{2}{*}{$\begin{array}{c}\text { Decrease } \\
\text { of } T_{\operatorname{Max}} \\
(\%)\end{array}$} & \multirow{2}{*}{$\begin{array}{c}\text { Increase } \\
\text { of } \mathrm{T}_{\mathrm{Min}} \\
(\%)\end{array}$} & \multirow{2}{*}{$\begin{array}{l}\text { Decrease in } \\
\text { Temperature } \\
\text { swings (\%) }\end{array}$} & \multicolumn{4}{|c|}{ Frequency of PCM activation } \\
\hline & & & & & & $\begin{array}{l}\text { PCM } \\
\text { Layer }\end{array}$ & Solid & $\begin{array}{l}\text { Phase } \\
\text { Change }\end{array}$ & Liquid \\
\hline \multirow{2}{*}{ July } & \multirow{2}{*}{$19.2-31.1$} & \multirow{2}{*}{15} & \multirow{2}{*}{$6 \%$} & \multirow{2}{*}{$18 \%$} & \multirow{2}{*}{$46 \%$} & Bio PCM & $29 \%$ & $28 \%$ & $43 \%$ \\
\hline & & & & & & Energain & $6 \%$ & $30 \%$ & $64 \%$ \\
\hline \multirow{2}{*}{ August } & \multirow{2}{*}{$19.9-35.7$} & \multirow{2}{*}{$13: 50$} & \multirow{2}{*}{$4 \%$} & \multirow{2}{*}{$16 \%$} & \multirow{2}{*}{$37 \%$} & Bio PCM & $7 \%$ & $18 \%$ & $74 \%$ \\
\hline & & & & & & Energain & $0 \%$ & $9 \%$ & $91 \%$ \\
\hline \multirow{2}{*}{ September } & \multirow{2}{*}{$15.2-31.1$} & \multirow{2}{*}{$12: 30$} & \multirow{2}{*}{$6 \%$} & \multirow{2}{*}{$19 \%$} & \multirow{2}{*}{$35 \%$} & Bio PCM & $57 \%$ & $18 \%$ & $25 \%$ \\
\hline & & & & & & Energain & $41 \%$ & $21 \%$ & $38 \%$ \\
\hline \multirow{2}{*}{ October } & \multirow{2}{*}{$11.2-25.6$} & \multirow{2}{*}{11} & \multirow{2}{*}{$1 \%$} & \multirow{2}{*}{$24 \%$} & \multirow{2}{*}{$18 \%$} & Bio PCM & $86 \%$ & $7 \%$ & $6 \%$ \\
\hline & & & & & & Energain & $60 \%$ & $28 \%$ & $12 \%$ \\
\hline
\end{tabular}




\section{Chapter 6 : Discussion}

The focus of this section is to provide an overview of the results obtained by the whole building simulation study and the detailed experimental analysis. The final step is to revise the initial research objectives and determine if the results effectively address the focus of the study.

\subsection{Correlation of simulation studies and experimental tests}

As discussed in section 3.1, due to simplifications in simulation software considering PCM behavior, numerous studies have conducted experimental tests to validate their numerical or simulation assessments. Experimental tests provide actual data which could be compared with the process of numerical calculations that might result in adjustments or clarification of results obtained from those numerical calculations. An important note about the validation of simulation model is to have similar or exact conditions in the experimental setup in order to compare the studies. In this thesis, the results of the experimental and simulation studies are not directly comparable as the configurations and test situations are not identical. Main factors that prevent a direct comparison between the two studies are presented in Table 6.1.

Table 6.1. Different factors of simulation and experimental study

\begin{tabular}{|c|c|}
\hline Simulation Study & Experimental Test \\
\hline $\begin{array}{c}\text { Concrete Structure: } \\
\text { Additional thermal mass in } \\
\text { the units }\end{array}$ & $\begin{array}{c}\text { Light weight structure: No } \\
\text { additional thermal mass }\end{array}$ \\
\hline $\begin{array}{c}\text { Adiabatic surfaces except for } \\
\text { one exterior wall with RSI: } 3.6 \\
\mathrm{~m}^{2} . \mathrm{K} / \mathrm{W}\end{array}$ & $\begin{array}{c}\text { All surfaces exposed to } \\
\text { outdoor environment with } \\
\text { average RSI: } 1.5 \mathrm{~m}^{2} . \mathrm{K} / \mathrm{W}\end{array}$ \\
\hline Active conditioning & Passive outdoor conditions \\
\hline $\begin{array}{c}\text { Double glazed windows in the } \\
\text { facade }\end{array}$ & $\begin{array}{c}\text { Single pane glass for the } \\
\text { exterior façade }\end{array}$ \\
\hline $\begin{array}{c}\text { Timeline: } \\
\text { Annual }\end{array}$ & $\begin{array}{c}\text { Timeline: } \\
\text { July to October }\end{array}$ \\
\hline
\end{tabular}

However, there are certain similarities between the test cell and the simulation unit including available shading. Test cell and unit size have a similar ratio. in fact, the test cells are 10 times smaller than the actual modeled unit with the same dimensional ratios. Furthermore, the entire enclosure of the walls and ceiling in the test cells resemble the finished interior enclosure in the simulation units as they both include gypsum board and the composite PCM system.

Even though the tests are not directly comparable, multiple similarities and connections could be made between their results, specifically as the detailed investigation of each individual layer in the composite PCM system is not possible in the simulation tests. Thus, the activation patterns of the composite PCM system in regards to solar gain and boundary condition 
variations in the experimental test could complement the findings from the simulation analysis. In fact, the initial focus of this study was to carry out whole building simulation to assess the impact of PCMs in interaction with other building systems and functions while the experimental test would be dedicated to the PCM investigation on a small scale. As the experimental results only provide temperature and heat transfer data, the results obtained for indoor temperature assessment in the simulation analysis is considered here.

\subsubsection{Effect of boundary conditions and solar gain on PCM effectiveness}

Regarding passive conditions in the experimental test cells and the actively controlled environment in the units, a different behavior is observed in PCM effectiveness in controlling indoor air temperature swings and peak temperature variations. In addition to differences between experimental test cells and simulation models, test variables are also different in each study. As the chart below shows, these variables have been tested differently in each study:
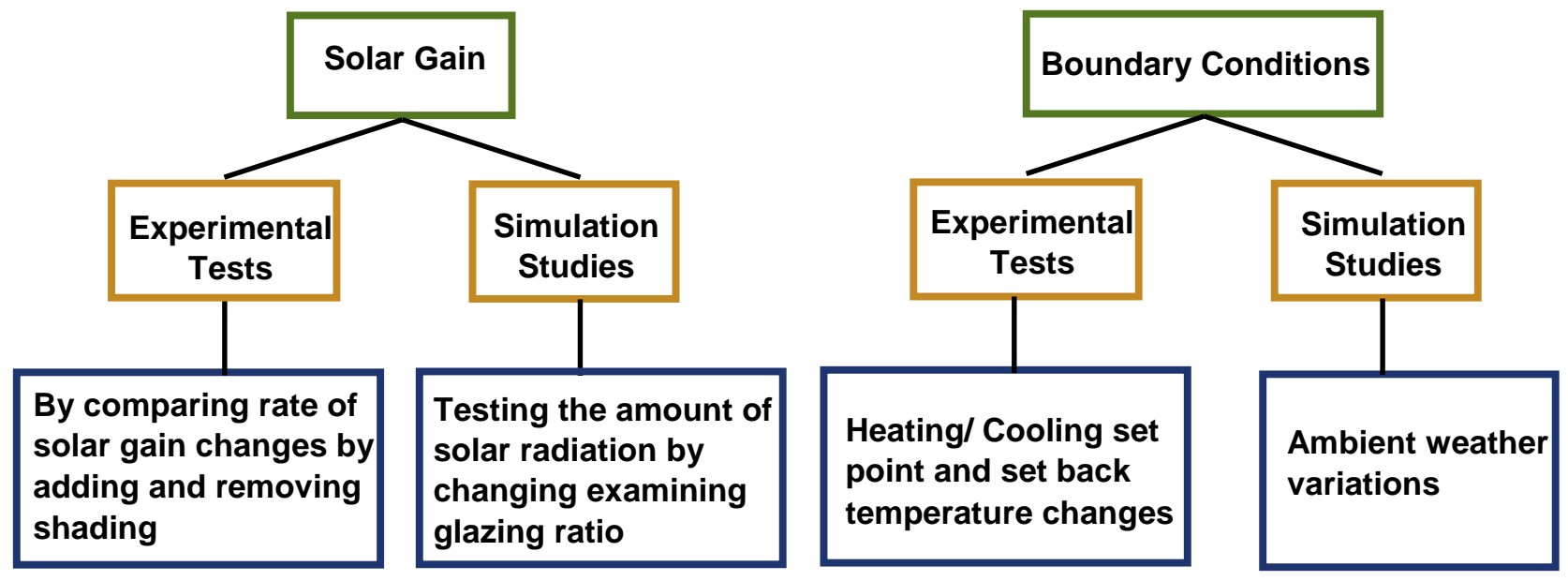

Figure 6.1. Testing solar gain and boundary conditions

The results obtained from the experimental tests clearly show that the performance of the composite PCM surfaces depends primarily on ambient weather variations. The vulnerability of the tests cells in direct contact with ambient weather has a large impact on indoor cell temperatures. However, this vulnerability is significantly reduced in the composite PCM test cell in which the indoor and surface temperatures are controlled by more than $6{ }^{\circ} \mathrm{C}$ in summer and fall months. In contrast, in the mechanically conditioned apartment units, in the simulation model, the impact of solar gain is the main driving factor for radiant temperature variations. Automatic heating and cooling systems control the indoor environment and reduce the vulnerability of indoor temperature to outdoor weather variations to some extent. However, the constant set point temperatures and indoor air temperatures do not correspond with the higher rate of change observed in radiant temperature values obtained by the simulation results, which impacted directly by solar gain changes.

This finding is consistent with the results of previous research done by Liu (1993) and Muruganantham (2010) which have performed experimental tests in outdoor unit with active and 
passive temperature control. Even though these studies were performed in different locations and periods, the first one in Montreal in winter, and the second study by Muruganantham in Arizona, they share similar observations.

In conclusion, regardless of discrepancies between the two tests, the composite PCM system showed that the highest rate of change in radiant temperatures occurs when the system is exposed to extreme temperature conditions. The definition of extreme temperature changes is different in each test, as in the experimental tests, large daily temperature swings in outdoor weather from day to night is considered extreme. In simulated units, extreme situations are observed in highly glazed units susceptible to high solar gain and heat loss.

Finally, to show the rate of change by using the composite PCM system monitored in passive and active conditions in the experimental and simulation study, a daily analysis is performed. Figures 6.2 and 6.3 show the rate of change in the indoor air and surface temperatures in relation to ambient weather variations in three days in July in Toronto. Shading is available in both experimental and simulation study and the surface temperature shown is for the window facing wall. Due to thermal capacity, indoor air temperatures in both figures are higher than outdoor temperatures. Yet considering the pattern of change in Fig. 6.2, an apparent trend is observed between indoor air and surface temperatures of the reference test cell with outdoor temperatures. In the composite PCM cell, a similar pattern is observed with more stable temperature range and lower peak temperatures. Furthermore, an apparent peak temperature shift is observed in the composite PCM test cell as a result of the thermal lag.

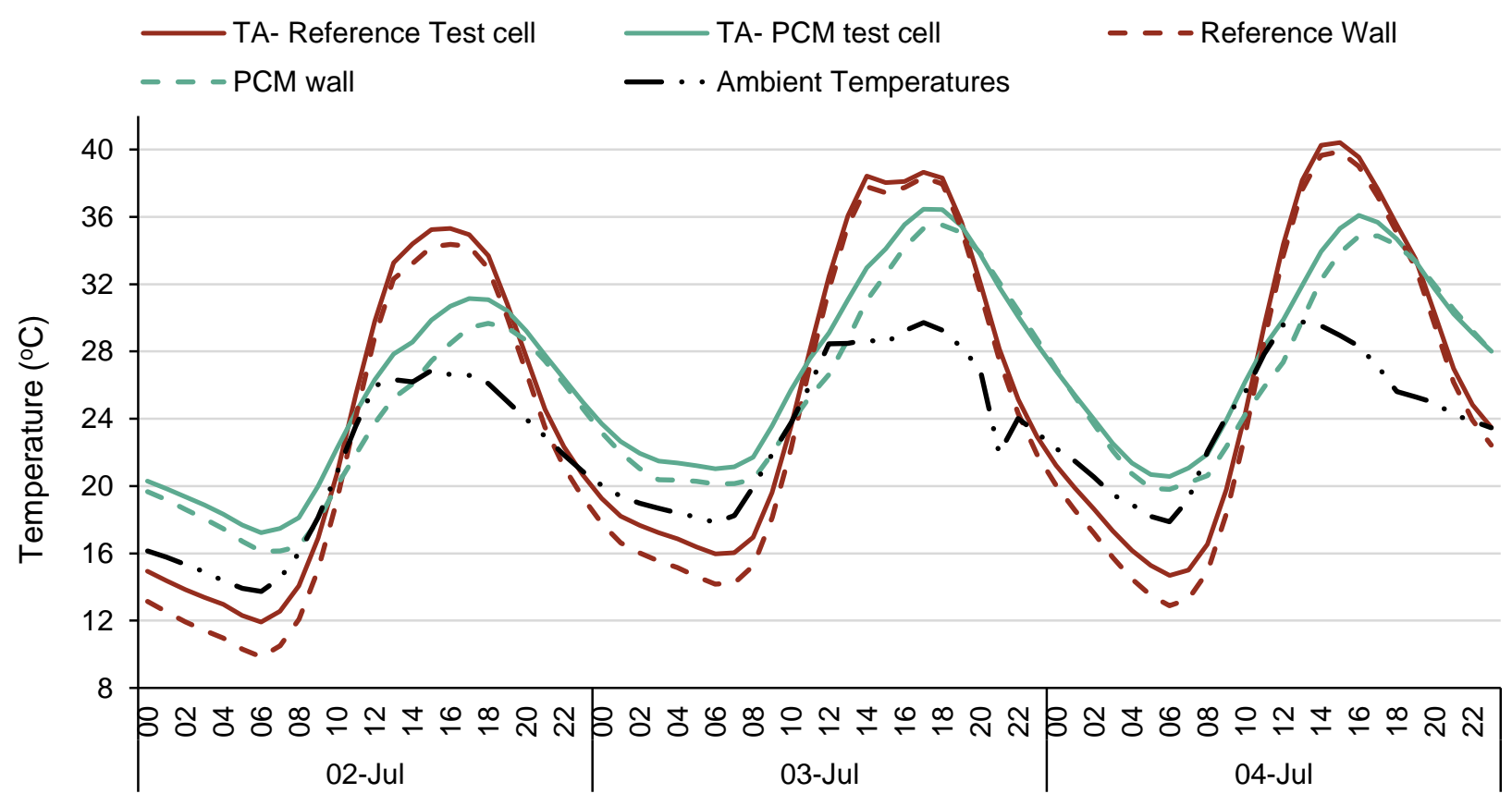

Figure 6.2. Indoor air, surface and outdoor temperature variations in experimental test cells 


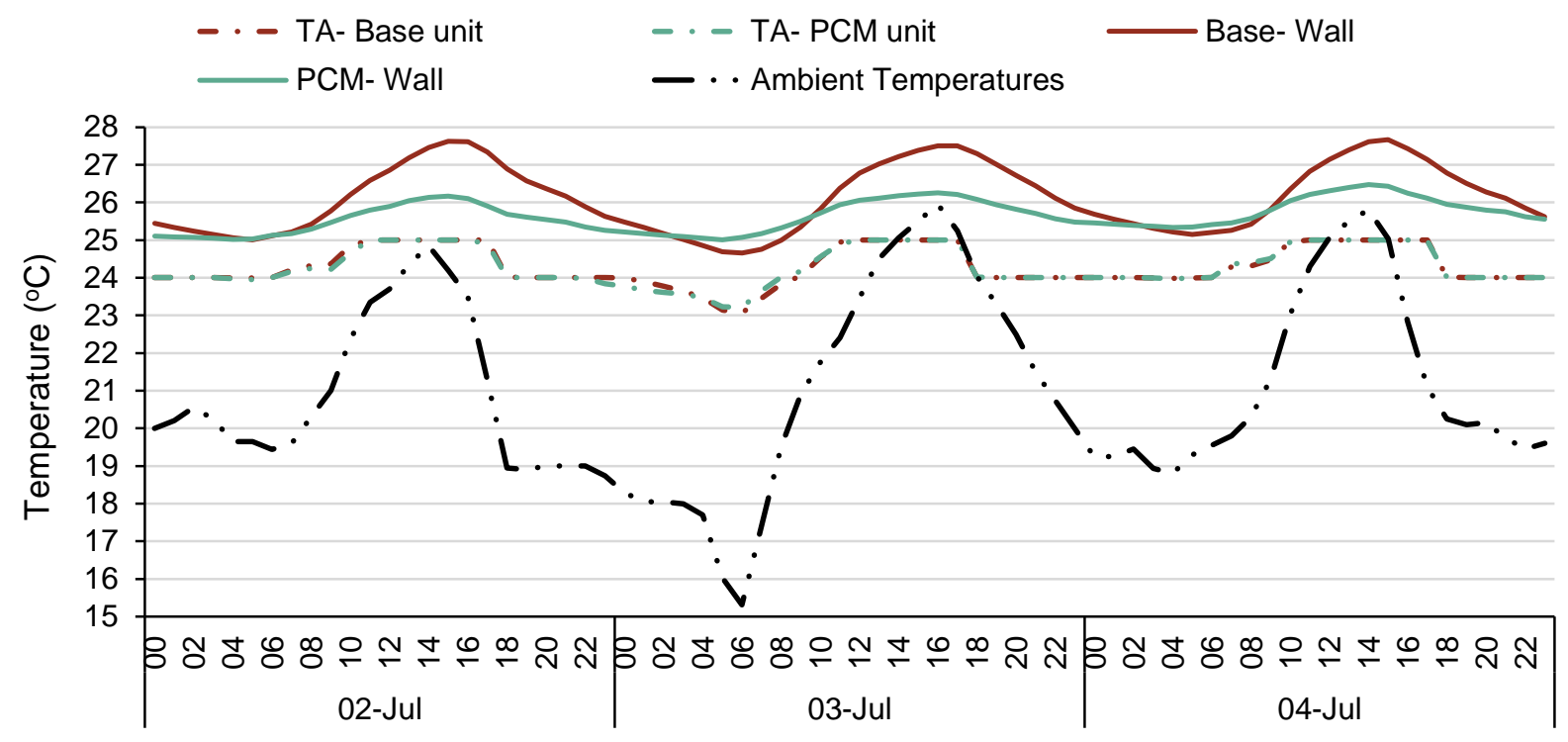

Figure 6.3. Indoor air, surface and outdoor temperature variations in the simulation model

On the same days in July, the simulation results in Fig. 6.3 show a distinct contrast to the results in Fig. 6.2. Indoor air temperature variations are constant in the range of cooling set point (24 ${ }^{\circ} \mathrm{C}$ ) and set back temperatures $\left(25^{\circ} \mathrm{C}\right)$. Surface temperatures are controlled in the PCM integrated unit and vary close to the melting range of layer one. The pattern of change in surface temperatures resembles the pattern of change in outdoor temperatures, however comparing the same $80 \%$ WWR unit with $60 \%$ and $40 \%$ WWR, the higher impact of solar gain on radiant temperatures is observed.

Comparing the exact activation patterns of each layer in the composite PCM system in the experimental tests shows a high activation for both layers in extreme high and low temperature and distinctly shows that the Energain layer is suitable for colder months, while the Bio PCM layer is intended for summer to reduce overheating. Lack of available data on a surface level in the simulation prevents direct comparison. However, comparing the rate of change observed in each study, the activation and impact of the composite PCM system are much higher in the experimental tests. The melting and solidification patterns are clearly visible in relation to ambient weather variations which shows how the surfaces in the test cell affect indoor air temperatures.

In conclusion, the overall range of PCM effectiveness on a whole building scale was shown using the simulation analysis, however considering the actual performance and activation of the composite PCM system, experimental tests are more reliable. The following issues in the simulation model might be the reason for such noticeable discrepancy between the experimental results and the simulation results on PCM activation.

* Availability of thermal mass with concrete in the simulation model:

Even though concrete has a high thermal storage capacity, large temperature swings and energy use in baseline units showed the vulnerability of the units to temperature fluctuations with existing concrete. The calculation of the sensible thermal energy storage for the 
concrete structure is not clear in the simulation mode. Therefore, the rate of available thermal storage in the unit and how it impacts the overall temperatures and energy use in the units are not known. It is therefore not possible to ensure if the lower activation of the composite PCM system in the modeled unit is due to available thermal storage. Further experimental tests using a large-scale testing set up resembling actual units with the exact ensure could be a better alternative in quantifying the sensible to latent ratio and how these two thermal storage systems affect each other and the indoor unit environment.

\section{Inaccurate PCM data inputs:}

PCM properties required for the simulation software were obtained by manufacturer data sheets and are nominal values, however, as previously mentioned in the literature review, inaccurate and simplified inputs into the simulation model leads to inaccurate results. This might be another factor leading to discrepancy in the simulation model, thus, it is necessary to perform thermal performance tests for the PCM panels using T-history or DHFMA tests to obtain the exact thermal properties for the composite PCM system to be correctly inputted into the system.

\section{* Melting and freezing cycles of PCMs:}

The inability of the software to consider the difference between the melting and freezing curves of the PCM has a clear impact on the cycle of PCM activation in the simulation model when compared to the experimental results. The simulation inputs for each PCM layer considered an average of melting and freezing curve of each PCM product as Energy Plus is unable to calculate two curves for the PCM. This might explain the results showing a lower capability of PCMs in affecting low peak temperatures. This is demonstrated as the results of the simulation study clearly showed the higher impact of this system on reducing high peak temperatures, while as shown in Table 5.7, the impact to the system in the experimental tests is recorded to be higher in increasing low peak temperatures.

The increase in minimum temperatures is directly linked to solidification. This explains the low rate of change observed in winter months in the simulation models. Considering surface temperature variations on winter nights, the impact of solidification in Energain layer to moderate indoor and surface temperatures and ultimately reduce cooling is minimal. In fact, the detailed results in the winter months suggest a total inactivation of Energain layer even though indoor temperatures are within its melting range. This could be an issue attributed to the simulation software that may not have accurately considered the second PCM layer in the enclosure.

In conclusion, it is assumed that by adjusting and studying the factors mentioned in the simulation model, the expected outcome might vary considerably. In fact, to reflect the actual capability of the composite PCM system in the simulation model based on the experiential test results, these steps are necessary. If the performance of the composite PCM system is quantified correctly using large scale test cells with actual building enclosure, better results in total energy use and thermal comfort could be observed in apartment units. By revising the simulation study using the above suggestions, better results could be obtained by applying this composite PCM system in high-rise apartment units. 
While upgrading the simulation model with accurate data inputs from DHFMA tests could lead to more accurate results, the quantification of both melting and freezing curves and the problem in assessing all the layers remains. Using a large-scale test setup is more preferred as the actual performance of the composite PCM system could be quantified resembling actual enclosure in apartment units and could further be actively conditioned. This type of experimental test is a more reliable method to expand on the findings of this research.

\section{Configuration of the composite PCM system}

Another similar result observed in both the simulation and the experimental analysis is that the PCM integrated ceilings perform better in reducing high peak temperatures. Thus an alternative configuration to a composite PCM concept is to apply one layer of PCMs with high melting temperatures- here the Bio PCM $\left(\mathrm{T}_{\mathrm{mp}}\right.$ of $\left.25^{\circ} \mathrm{C}\right)$ - to the ceiling and apply one layer of the PCM with lower melting temperature- here the Energain $\mathrm{PCM}\left(\mathrm{T}_{\mathrm{mp}}\right.$ of $\left.21.7^{\circ} \mathrm{C}\right)$ to the walls. With this possibility multiple other configurations could be designed, soldiering the better performance of the ceiling surfaces in higher temperatures.

\subsection{Results and research objectives}

The results of this research could effectively address the initial research focus. By targeting specific variables to address all the research objectives, appropriate results have been obtained. This section merely points to the most important metrics.

\section{Research focus:}

* The relation between solar heat gain in apartment units and the effectiveness of PCMs' thermal energy storage

The results clearly point to a high influence of solar gain in apartment units on PCM activation patterns and how the PCMs, in turn, affect indoor thermal environment and energy use. The influence of solar gain is more critical in shoulder and heating seasons. As the best results were observed in units with $80 \%$ WWR, the effect of high heat loss in addition to high heat gain becomes an important factor that must be considered. However, by relating the appropriate melting range to indoor conditions the extreme fluctuations in these situations are controlled.

By testing different orientations, it was concluded that the impact of solar gain though critical in impacting surfaces, is more periodical and has a direct relation to time of peak temperatures in apartment units. For instance, in both experimental and simulation tests, a significantly high temperature period was observed in west facing units as the sharpest solar gain was experienced. In contrast, south facing units experienced more balanced and stable conditions throughout the days.

It is assumed that by matching solar peak and solar period with the HVAC set points in each orientation, different results could be obtained. For instance, considering the west facing units near sunset periods which experience high temperatures, cooling systems could run on set back temperatures to allow for passive cooling as the PCMs store the energy. In heating 
seasons similar action could be performed as the heating could even be on set back for the entire night as the long thermal lag during the night and lower temperatures would facilitate a full solidification, leading to release of stored energy in the PCMs.

* The connection between indoor air temperatures with the melting temperature of PCMs by monitoring their performance and impact on energy use and indoor temperatures

While many factors such as internal gains and solar gains affect indoor temperatures, a difference of 1 to $2^{\circ} \mathrm{C}$ variation between main set point and PCM melting point is optimal. Considering the low set back temperatures in winter and pattern of PCM effectiveness, it could be inferred that the PCMs are not melted during the day with a low set back temperatures of $18{ }^{\circ} \mathrm{C}$, even though solar gains are high. Therefore, increasing set back temperatures in winter could be more beneficial in activating the PCM layers, and the savings in energy at night through PCM solidification could compensate for the higher set back operation.

However, in summer as expected solidification of PCMs at night is a problem that affects their heat storage capacity in the next cycle. While lowering cooling set points at night is an option, but increasing mechanical flow rate could be to facilitate the full night discharge of the composite PCM system.

Finally, it must be pointed that this research was not focused on finding an optimal or fixed solution for PCMs, rather find the relative factors that affect PCM integration in buildings. The outcomes of each test in relation to the main research focus have clearly identified that the dynamic performance of PCM systems in buildings depends on various interrelated factors. Ultimately an optimal solution is only achieved relative to each case specific condition when all parameters are in a relative balance. 


\section{Chapter 7 : Conclusions}

The potential of thermal energy storage using phase change materials was investigated in the retrofit of high-rise apartments in two cities of Toronto and Vancouver. A summary of the research and final conclusions drawn from each individual analysis is presented here to relate the findings to main research aims and how this research could contribute to future studies.

\section{Summary}

While urbanization is a shift of living conditions, it must be ensured that buildings also adapt with time and current construction principles to improve the quality of life and reduce their environmental footprints. High-rise apartments hold a significant share in existing residential stock in Toronto and Vancouver and their popularity continues to grow as a prominent choice of housing in urban areas. Thus, retrofit in this typology of buildings would have a high impact on total energy consumption and GHG emission reduction on an urban scale. Furthermore, addressing current challenges and adapting existing apartments to better performance standards is necessary to conserve the resources and assets of these buildings.

Space conditioning for maintaining indoor thermal comfort dominates the energy consumption share in residential apartments. Therefore, in this study thermal energy storage was proposed as a potential retrofit measure to address energy efficiency and indoor temperature regulations. Even though thermal energy storage measures have many implications in regulating indoor environments, their impact on reducing temperature extremes and daily temperature fluctuations is the most important aspect. Consequently, by mitigating these thermal comfort issues, the need for adjusting indoor environment conditions would also decrease which will influence the pattern of energy consumption.

Phase change materials as an innovative thermal energy storage approach were selected in this study primarily for their suitability and ease of application to retrofit projects. Additionally, the thermal capacity of PCMs compared to conventional thermal mass materials is higher in narrow temperature ranges showing more benefits in retrofit applications. An extensive literature review was provided to give an insight into PCM applications in buildings and the overall impacts of integrating these materials.

The aim of this research was to provide year-around latent thermal energy storage to regulate seasonal thermal comfort and decrease annual energy use in high-rise apartments in Toronto and Vancouver. As the most important characteristics of PCMs is their melting point which must correspond with indoor boundary conditions, two PCM products were selected to form a hybrid PCM system. The products used in this composite PCM system have two different melting points, each targeting heating and cooling seasons differently. This composite PCM system was applied to walls and ceiling surfaces of apartment units to maximize effectiveness, mainly by affecting indoor air temperatures through changing radiant temperatures in the units.

The research process involved two main stages, first, the design and optimization of a composite PCM system suitable for the climate and building typology. The second stage was to quantify the performance and impact of the designed PCM system on energy use and the overall thermal environment. A detailed overview of literature was conducted to find the optimal methodology to assess PCM integration to buildings. Finally, both numerical and experimental 
methodologies were adopted to investigate first the overall impact of PCMs in high-rise apartments, and second to examine the functioning of the composite PCM system in detail.

The main categorization factor for high-rise apartments in this study is the window to wall ratio to draw a correlation with solar radiation and PCM performance, which was further examined by studying the impact of building orientation in both simulation and experimental tests. Indoor boundary conditions were examined by variable set point temperatures for HVAC systems in the simulation study and passive outdoor weather variation in four months in the experimental tests.

\section{Main Findings}

The following points are a summary of main findings in this thesis:

- Integration of the composite PCM system is beneficial on an annual basis with considerable reduction in annual and monthly energy use in addition to reduction of daily temperature fluctuations;

- While using the composite PCM system has positive impacts in all building categories investigated, the highest rate of change was observed in highly glazed apartment units with $80 \%$ WWR units facing the south orientation;

- The compatibility of the composite PCM system in Canadian climate showed positive results. The effectiveness of the composite PCM system is higher in Vancouver units. Highest energy saving and indoor temperature regulations in Vancouver are observed in the summer season. In Toronto, highest percentage of saving and better temperature regulation occur in the shoulder season;

- The effectiveness of integrating the composite PCM system in high-rise apartment units with concrete structure shows the addition of thermal energy storage to already high mass concrete system;

- The negative performance of the PCM in the heating season on energy use specifically in Toronto units was concluded to be related to heat loss in highly glazed buildings at night. However, this study did not consider any prior retrofits or improvement in thermal resistance of the exterior enclosure. Therefore, enhancement of the exterior enclosure accompanied by the PCM system could show better performance of the composite PCM system in the heating season as well;

- Having two melting points in one zone is beneficial and the results of the experimental tests clearly demonstrated the activation of each layer in this hybrid system. Specifically, in shoulder seasons with high monthly temperature variations exists, the PCM system showed great performance in both experimental and simulation analysis. In units with four pipe fan coil system that automatically transition between heating and cooling based on temperature variations, both heating and cooling energy could be considerably saved by adopting this PCM system;

- Increased stability of indoor temperatures for longer periods during the day and specifically during the night elaborated the decreased vulnerability of the PCM integrated units or test cells to ambient weather variations. This factor is directly linked to the 
resiliency of these buildings to weather conditions in addition to the decrease of reliance on mechanical systems;

- Finally, analysis of the influence of research variables on PCM performance showed that passive design features in buildings such as glazing ratio, orientation, and shading have a significant impact on PCM activation. However, boundary conditions in contact with the PCMs have the highest influence ensuring PCM performance, while it must be considered that many of the mentioned passive features affect indoor boundary conditions to some degree.

\section{Perspective on high-rise residential buildings in Canada}

High-rise apartments with large glazing ratios showed the highest rate of energy and thermal comfort improvement with additional thermal energy storage using PCMs. This category of highrise apartments is relatively newer, frequently constructed after 1990. Large windows and sunlit spaces are attractive to potential buyers, moreover window wall system are a cheaper option for construction compared to conventional brick or concrete facades. Consequently, construction of highly glazed apartments is growing, while their performance and energy efficiency is deteriorating. According to CBC (2011) and Kesik (2011), this type of condo buildings has a short life-span of 25 years or less with poor energy performance compared to their counterparts from the 70's.

There are major defects with window wall systems in many high-rise apartments such as water and structural damages that have a priority for future retrofits, in fact, in many cases, the entire window system needs to be replaced and removed. Removing the entire envelope or even reducing the aperture size could show the most beneficial approach for an energy retrofit, yet it is very costly. Additionally, in such retrofits occupants are required to leave which also entails a compensation cost adding to the overall retrofit expense. Incorporating PCMs is an unobtrusive method that could complement the existing window to wall ratio to control the daily temperature swings in spaces. Furthermore, if overall façade repair occurs and the window systems are upgraded the PCMs might show better performance as the rate of extreme heat loss and heat gain would be eliminated.

Considering buildings with lower WWR which mostly represent older buildings, other factors such as older mechanical systems or low resistance enclosure is the main issues that must be addressed in retrofit projects. Even though Toronto and Vancouver are both heating dominated, higher comfort expectations and increasing temperatures due to climate change have lead to mass use of air conditioning systems in summer. As expected, the integration of PCMs in units reduces the vulnerability of the units to external temperature and solar loads. Longer stability of radiant temperature affecting air temperatures decreases active cooling as passive cooling is prolonged for a longer period. Peak energy load reduction which is another outcome of incorporating PCMs is an important benefit in addition to overall energy use reduction that could potentially reduce high operational costs in high-rise apartments. Maintenance fees are a huge part of expenses in high-rise buildings however with measures such as adding PCMs, the operational costs could be mitigated. Moreover, peak energy reductions at peak periods in these buildings which are large energy consumers would take the load off utilities. 


\section{Contribution to future studies}

As stated continuously throughout this thesis, performance and efficiency of PCMs vary in different situations and their design and performance are strictly case specific. Therefore, the findings of this thesis may not be directly applicable to other cases, although the design methods used in this thesis should be adopted and further expanded. The analytical overview of how variables are interrelated and how they affect PCMs was shown in this study and presented the challenging quantification of PCMs. Therefore, critical evaluation of factors that could affect the dynamism of these products must be considered.

The replicability of the methods and variables investigated in future studies targeting retrofit or new construction scenarios in different climates or building typologies could present a collective range of results in addition to the findings in this research on how a composite PCM system is a potential solution to increase thermal energy storage in buildings. The aim of this research was to create a model that could be used and extended in future studies as well. Starting from PCM design and optimization to assess PCM impacts and evaluation of what variables impact PCM performance, similar approaches in different cases studies could be conducted.

\subsection{Future works}

This research addressed the initial research focus and illustrated the performance of PCMs in high-rise apartments, however other factors and topics could also be studied in future research such as:

* Testing different variations of hybrid PCM systems using different PCM products with different melting point and latent heat ranges. Considering the approach in this study using two melting points in one system that was applied to all surfaces, a different approach is: to use single layer of PCMs with different melting points in ceiling and walls. For instance, using a higher melting point PCM in the ceiling and a lower melting point PCMs in the walls;

* Studying the potential of PCMs in combination with other retrofit measures, such as envelope enhancement or mechanical system improvements;

* Studying the impact of the same or similar composite PCM system on corner apartment units with 2 or more glazing areas;

* Only apartment units with existing balconies that act as shading have been tested in the simulation analysis, however as the experimental tests showed, shading has a notable impact on PCM performance. Thus, studying high-rise apartments without balcony is also necessary;

* The main categorization factor for high-rise buildings in this study was glazing ratio and the outcomes clearly showed the better performance of the composite PCM system in buildings with higher WWR. Even though using latent storage helped in regulating indoor environment and reducing energy use, comparing impacts of reducing glazing ratios with the results of this study could be beneficial to compare different retrofit measure; 
* This study considered typical high-rise buildings with existing thermal mass of concrete structures, however examining the performance of PCMs in high-rise buildings with steel structure should be done;

* In the experimental tests, further detailed measurements of solar irradiance and natural ventilation air flow could be beneficial in determining how much solar gain and air flow is needed for melting and solidification of the PCM layers;

* The main characteristic of PCMs analyzed in this thesis was PCM's melting temperature, however studying the influence of latent heat variation in high-rise apartments would provide useful information on how thermal capacity variations affect comfort and energy;

* It is well known that PCMs are mainly targeted for buildings with light weight structures to increase their thermal inertia. However, results of this study demonstrated the effectiveness of PCMs in concrete buildings. To ensure that balance in thermal energy storage and cost saving is maintained, a detailed study is necessary to compare the latent to sensible ratio in high-rise apartments with concrete structure;

* Finally, a comprehensive cost analysis of the proposed system cost saving from operational system and payback periods is required to fully outline the benefits of this PCM system as a retrofit measure.

\section{Final note:}

The focus of this thesis was to explore the impact of PCMs on indoor temperatures of apartment units, and how different factors such as solar gain could influence the performance of these products. Considering the more reliable outcomes from the experimental tests in quantifying the behavior of the composite PCM system, the full potential of this system in changing surface and indoor temperatures and ultimately the decrease vulnerability of the room it is applied to was demonstrated. However, the parametric evaluation of different factors influencing PCM performance in the simulation analysis is beneficial in showing the rate of change in PCMs and what needs to be considered for design and optimization of PCM applications.

The most notable outcome of this thesis is the evaluation and overview of commercial PCM products. Quantification of how market available PCM products perform in the Canadian context is important to show the reality of available PCM products and their benefits as opposed to possible PCM scenarios. Considering two different climates in Canada, extreme climate conditions in Toronto and mild conditions in Vancouver showed that including PCMs is beneficial in both climates as the additional thermal inertia allows for significant radiant and indoor temperature regulation.

The highest advantage of the composite PCM system in this study is first the inclusion of two different melting points in one system, second is the high latent heat storage capacity in a thin layer. With only $2 \mathrm{~cm}$ thickness which is a thin and unobtrusive addition, suitable for retrofit projects, significant thermal storage is provided that has the potential to considerably alter the indoor environment. In conclusion, hybrid PCM systems, using two or more PCM products with different melting points have a great potential in becoming a more prominent approach for PCM application in buildings. 


\section{Appendix}

\section{Appendix I: Simulation study additions}

\section{Section 4.1.}

\section{Data inputs in Design Builder simulation model:}

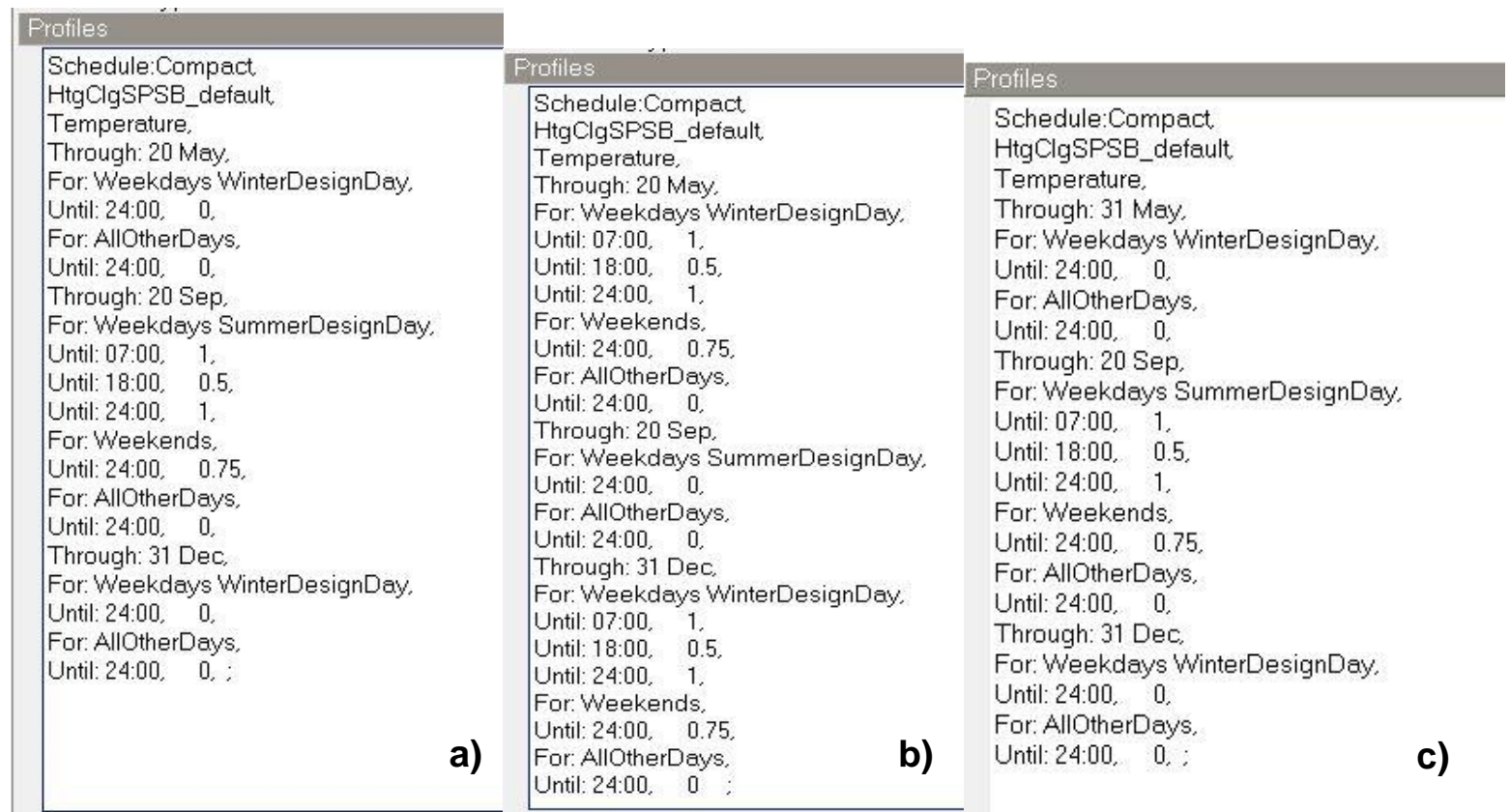

Figure 1. a) Cooling system schedules, b) Heating system schedule, c) Mechanical ventilation schedule

\begin{tabular}{|c|c|}
\hline Q HVACTemplate & $\approx$ \\
\hline InTemplate & CONDO - Fan Coil Unit (4-Pipe) with District He \\
\hline Q Mechanical Ventlation & 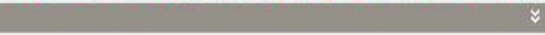 \\
\hline 四 On & \\
\hline Outside air definition method & 3-Min fresh air (Per area) \\
\hline Operation & 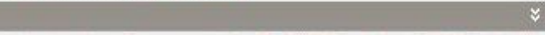 \\
\hline (iat Schedule & Ventilation Summer-HtgClgSPSB_default 6:00 - 18:00 \\
\hline Fans & \#) \\
\hline (5) Auxiliary Energy & $\bar{z}$ \\
\hline Pump etc energy $(\mathrm{W} / \mathrm{m} 2)$ & 0.0000 \\
\hline (iAd Schedule & Dwell_DomCommonAreas_Occ \\
\hline I Heating & 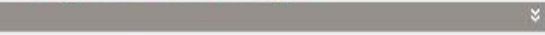 \\
\hline ఐ Heated & \\
\hline Fuel & 2-Natural Gas \\
\hline Heating system seasonal CoP & 1.000 \\
\hline Type & \#) \\
\hline Operation & $\approx$ \\
\hline [iid Schedule & WINTER-HtgClgSPSB_default 6:00 - 18:00 Mon - Fri \\
\hline *Cooling & $\approx$ \\
\hline 甲 Cooled & \\
\hline 嚅Cooling system & Default \\
\hline Fuel & 1-Electricity from grid \\
\hline Cooling system seasonal $\mathrm{CoP}$ & 1.000 \\
\hline Supply Air Condition & 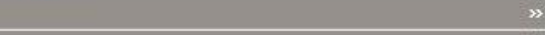 \\
\hline Operation & 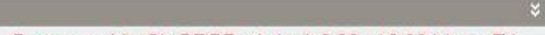 \\
\hline [iid| Schedule & Summer-HtgClgSPSB_default 6:00 - 18:00 Mon - Fri \\
\hline
\end{tabular}

Figure 2. HVAC data inputs in Design Builder model 
Tabular data inputs for enthalpy-temperature function in Design Builder (Energy Plus):

A range of $0.5^{\circ} \mathrm{C}$ of temperature change is considered in the software to show the rate of change after the PCMs nominal melting point is reached.

Bio PCM- $\mathrm{T}_{\mathrm{mp}}: 23^{\circ} \mathrm{C}$

\begin{tabular}{|r|r|r|}
\hline \multicolumn{1}{|c|}{ Points } & $\begin{array}{c}\text { Temperature } \\
\left({ }^{\circ} \mathbf{C}\right)\end{array}$ & Enthalpy (J/Kg) \\
\hline 1 & 0 & 0 \\
\hline 2 & 5 & 10620 \\
\hline 3 & 10 & 21240 \\
\hline 4 & 15 & 31860 \\
\hline 5 & 20 & 42784 \\
\hline 6 & 21 & 46960 \\
\hline 7 & 22 & 63908 \\
\hline 8 & 22.5 & 89930 \\
\hline 9 & 23 & 136537 \\
\hline 10 & 23.5 & 192819 \\
\hline 11 & 24 & 235404 \\
\hline 12 & 25 & 267806 \\
\hline 13 & 27 & 277259 \\
\hline 14 & 28 & 279460 \\
\hline 15 & 29 & 281594 \\
\hline 16 & 30 & 283719 \\
\hline
\end{tabular}

Bio PCM- $\mathrm{T}_{\mathrm{mp}}: 25^{\circ} \mathrm{C}$

\begin{tabular}{|r|r|r|}
\hline \multicolumn{1}{|c|}{ Points } & \multicolumn{1}{|c|}{$\begin{array}{c}\text { Temperature } \\
\left({ }^{\circ} \mathbf{C}\right)\end{array}$} & $\begin{array}{c}\text { Enthalpy } \\
(\mathbf{J} / \mathbf{K g})\end{array}$ \\
\hline 1 & 0 & 0 \\
\hline 2 & 5 & 10500 \\
\hline 3 & 10 & 21000 \\
\hline 4 & 15 & 31500 \\
\hline 5 & 21 & 44698 \\
\hline 6 & 23 & 58497 \\
\hline 7 & 24 & 87850 \\
\hline 8 & 24.5 & 116680 \\
\hline 9 & 25 & 154593 \\
\hline 10 & 25.5 & 194382 \\
\hline 11 & 26 & 227335 \\
\hline 12 & 26.5 & 249792 \\
\hline 13 & 27 & 263305 \\
\hline 14 & 28 & 275472 \\
\hline 15 & 29 & 280102 \\
\hline 16 & 30 & 282810 \\
\hline
\end{tabular}

Energain- $\mathrm{T}_{\mathrm{mp}}: 21.7^{\circ} \mathrm{C}$

\begin{tabular}{|r|r|r|}
\hline \multicolumn{1}{|c|}{ Points } & $\begin{array}{c}\text { Temperature } \\
\left({ }^{\circ} \mathbf{C}\right)\end{array}$ & $\begin{array}{c}\text { Enthalpy } \\
(\mathbf{J} / \mathbf{K g})\end{array}$ \\
\hline 1 & 0 & 4000 \\
\hline 2 & 5 & 24000 \\
\hline 3 & 10 & 44000 \\
\hline 4 & 15 & 64300 \\
\hline 5 & 17 & 73974 \\
\hline 6 & 19 & 88326 \\
\hline 7 & 20 & 98594 \\
\hline 8 & 21 & 111160 \\
\hline 9 & 22 & 125494 \\
\hline 10 & 23 & 140494 \\
\hline 11 & 24 & 145373 \\
\hline 12 & 25 & 148950 \\
\hline 13 & 27 & 154866 \\
\hline 14 & 28 & 157696 \\
\hline 15 & 29 & 160517 \\
\hline 16 & 30 & 163337 \\
\hline
\end{tabular}




\section{Study \#1:}

\begin{tabular}{|c|c|c|c|c|c|c|}
\hline \multirow{2}{*}{ Toronto Units } & \multicolumn{2}{|c|}{$80 \%$ WWR } & \multicolumn{2}{|c|}{$60 \%$ WWR } & \multicolumn{2}{|c|}{$40 \%$ WWR } \\
\hline & Difference & $\Delta E_{\text {Saving }}$ & Difference & $\Delta E_{\text {Saving }}$ & Difference & $\Delta E_{\text {Saving }}$ \\
\hline $\begin{array}{l}\text { Total Energy } \\
\left(\mathrm{kWh} / \mathrm{m}^{2}\right)\end{array}$ & 4.33 & $2.6 \%$ & 3.3 & $2 \%$ & 1.6 & $1.1 \%$ \\
\hline $\begin{array}{l}\text { Heating Loads } \\
\left(\mathrm{kWh} / \mathrm{m}^{2}\right)\end{array}$ & 1.2 & $1.1 \%$ & 0.5 & $0.5 \%$ & -0.2 & $-0.2 \%$ \\
\hline $\begin{array}{l}\text { Cooling Loads } \\
\left(\mathrm{kWh} / \mathrm{m}^{2}\right)\end{array}$ & 3.1 & $14.7 \%$ & 4.5 & $11.4 \%$ & 1.8 & $14.3 \%$ \\
\hline
\end{tabular}

\begin{tabular}{|c|c|c|c|c|c|c|c|c|c|c|c|c|}
\hline \multirow{2}{*}{$\begin{array}{l}\begin{array}{l}\text { Toronto } \\
\text { Units }\end{array} \\
\text { HVAC } \\
\text { Sizing }\end{array}$} & \multicolumn{4}{|c|}{$80 \%$ WWR } & \multicolumn{4}{|c|}{$60 \%$ WWR } & \multicolumn{4}{|c|}{ 40\% WWR } \\
\hline & $\begin{array}{c}\text { Basel } \\
\text { ine } \\
\text { Unit }\end{array}$ & $\begin{array}{c}\text { PCM } \\
\text { integr } \\
\text { ated } \\
\text { unit }\end{array}$ & $\begin{array}{l}\text { Differ } \\
\text { ence }\end{array}$ & $\begin{array}{c}\text { savin } \\
\mathbf{g}\end{array}$ & $\begin{array}{c}\text { Baseli } \\
\text { ne } \\
\text { Unit }\end{array}$ & $\begin{array}{c}\text { PCM } \\
\text { integr } \\
\text { ated } \\
\text { unit }\end{array}$ & $\begin{array}{l}\text { Differ } \\
\text { ence }\end{array}$ & saving & $\begin{array}{l}\text { Bas } \\
\text { eline } \\
\text { Unit }\end{array}$ & $\begin{array}{l}\text { PCM } \\
\text { integr } \\
\text { ated } \\
\text { unit }\end{array}$ & $\begin{array}{l}\text { Differ } \\
\text { ence }\end{array}$ & $\begin{array}{c}\text { savin } \\
\text { g }\end{array}$ \\
\hline $\begin{array}{l}\text { User } \\
\text { design load } \\
\text { per area- } \\
\text { Cooling } \\
\left(\mathrm{W} / \mathrm{m}^{2}\right)\end{array}$ & 44.1 & 38.8 & 5.33 & $12.1 \%$ & 39.8 & 35.3 & 4.5 & $11.4 \%$ & 31.4 & 31.6 & -0.24 & $-0.8 \%$ \\
\hline $\begin{array}{l}\text { Design } \\
\text { cooling } \\
\text { load (W) }\end{array}$ & 2344.1 & 2053.5 & 290.62 & $12.4 \%$ & 2112.4 & 1862.7 & 249.7 & $11.8 \%$ & $\begin{array}{c}1665 . \\
7\end{array}$ & 1672.2 & -6.5 & $-0.4 \%$ \\
\hline $\begin{array}{l}\text { User } \\
\text { design load } \\
\text { Per area- } \\
\text { heating } \\
\left(\mathrm{W} / \mathrm{m}^{2}\right)\end{array}$ & 154.8 & 151.3 & 3.4 & $2.2 \%$ & 142.1 & 138.7 & 3.3 & $2.4 \%$ & 130.8 & 127.2 & 3.6 & $2.8 \%$ \\
\hline $\begin{array}{l}\text { Design } \\
\text { heating } \\
\text { load (W) }\end{array}$ & 7560 & 7362.3 & 197.8 & $2.6 \%$ & 6938.9 & 6740.7 & 198.13 & $2.9 \%$ & $\begin{array}{c}6389 . \\
4\end{array}$ & 6186.8 & 202.5 & $3.2 \%$ \\
\hline
\end{tabular}

Table series 1. Extension of Table 4.5. 


\begin{tabular}{|c|c|c|c|c|c|c|}
\hline \multirow{2}{*}{$\begin{array}{l}\text { Vancouver } \\
\text { Units }\end{array}$} & \multicolumn{2}{|c|}{$80 \%$ WWR } & \multicolumn{2}{|c|}{$60 \%$ WWR } & \multicolumn{2}{|c|}{$40 \%$ WWR } \\
\hline & Difference & $\Delta E_{\text {Saving }}$ & Difference & $\Delta E_{\text {Saving }}$ & Difference & $\Delta E_{\text {Saving }}$ \\
\hline $\begin{array}{l}\text { Total Energy } \\
\left(\mathrm{kWh} / \mathrm{m}^{2}\right)\end{array}$ & 4.33 & $2.6 \%$ & 3.3 & $2 \%$ & 1.6 & $1.1 \%$ \\
\hline $\begin{array}{l}\text { Heating Loads } \\
\left(\mathrm{kWh} / \mathrm{m}^{2}\right)\end{array}$ & 1.2 & $1.1 \%$ & 0.5 & $0.5 \%$ & -0.2 & $-0.2 \%$ \\
\hline $\begin{array}{l}\text { Cooling Loads } \\
\left(\mathrm{kWh} / \mathrm{m}^{2}\right)\end{array}$ & 3.1 & $14.7 \%$ & 4.5 & $11.4 \%$ & 1.8 & $14.3 \%$ \\
\hline
\end{tabular}

\begin{tabular}{|c|c|c|c|c|c|c|c|c|c|c|c|c|}
\hline \multirow{2}{*}{$\begin{array}{c}\begin{array}{l}\text { Vancouve } \\
\text { r Units }\end{array} \\
\text { HVAC } \\
\text { Sizing }\end{array}$} & \multicolumn{4}{|c|}{$80 \%$ WWR } & \multicolumn{4}{|c|}{$60 \%$ WWR } & \multicolumn{4}{|c|}{$40 \%$ WWR } \\
\hline & $\begin{array}{c}\text { Basel } \\
\text { ine } \\
\text { Unit }\end{array}$ & $\begin{array}{c}\text { PCM } \\
\text { integr } \\
\text { ated } \\
\text { unit }\end{array}$ & $\begin{array}{l}\text { Differ } \\
\text { ence }\end{array}$ & $\begin{array}{c}\text { savin } \\
\mathbf{g}\end{array}$ & $\begin{array}{l}\text { Baseli } \\
\text { ne } \\
\text { Unit }\end{array}$ & $\begin{array}{c}\text { PCM } \\
\text { integr } \\
\text { ated } \\
\text { unit }\end{array}$ & $\begin{array}{l}\text { Differ } \\
\text { ence }\end{array}$ & saving & $\begin{array}{l}\text { Bas } \\
\text { eline } \\
\text { Unit }\end{array}$ & $\begin{array}{c}\text { PCM } \\
\text { integr } \\
\text { ated } \\
\text { unit }\end{array}$ & $\begin{array}{l}\text { Differ } \\
\text { ence }\end{array}$ & $\begin{array}{c}\text { savin } \\
\text { g }\end{array}$ \\
\hline $\begin{array}{l}\text { User } \\
\text { design load } \\
\text { per area- } \\
\text { Cooling } \\
\left(\mathrm{W} / \mathrm{m}^{2}\right)\end{array}$ & 28.7 & 22.7 & 6.1 & $21 \%$ & 25.1 & 20 & 5.1 & $25.4 \%$ & 21.1 & 16.9 & 4.2 & $19.9 \%$ \\
\hline $\begin{array}{l}\text { Design } \\
\text { cooling } \\
\text { load (W) }\end{array}$ & 1524.3 & 1199.3 & 325 & $21.3 \%$ & 1332.2 & 1056.7 & 275.4 & $26.1 \%$ & $\begin{array}{c}1119 . \\
6\end{array}$ & 893.6 & 226 & $20.2 \%$ \\
\hline $\begin{array}{l}\text { User } \\
\text { design load } \\
\text { Per area- } \\
\text { heating } \\
\left(\mathrm{W} / \mathrm{m}^{2}\right)\end{array}$ & 120.8 & 116.8 & 4 & $3.3 \%$ & 111.5 & 107.9 & 3.5 & $3.2 \%$ & 106.3 & 100.7 & 2.5 & $2.5 \%$ \\
\hline $\begin{array}{l}\text { Design } \\
\text { heating } \\
\text { load (W) }\end{array}$ & 5899.3 & $\begin{array}{c}5680.8 \\
9\end{array}$ & 218.4 & $3.7 \%$ & 5444.1 & 5243.5 & 200.6 & $3.7 \%$ & $\begin{array}{c}5043 . \\
4\end{array}$ & 4899 & 144.28 & $2.9 \%$ \\
\hline
\end{tabular}

Table series 2. Extension of Table 4.5.

Extreme temperature variations by integration of the composite PCM system:

\begin{tabular}{|l|r|r|r|r|r|r|r|r|r|}
\hline CHANGE & \multicolumn{9}{|c|}{ Number of hours with Operative temperatures <21 ${ }^{\circ} \mathbf{C}$} \\
\hline \multirow{3}{*}{ Toronto } & \multicolumn{3}{|c|}{$\mathbf{8 0 \%}$} & \multicolumn{3}{|c|}{$\mathbf{6 0 \%}$} & \multicolumn{3}{|c|}{$\mathbf{4 0 \%}$} \\
\cline { 2 - 11 } & $\begin{array}{l}\text { Baseline } \\
\text { Unit }\end{array}$ & $\begin{array}{l}\text { PCM } \\
\text { Unit }\end{array}$ & Difference & $\begin{array}{l}\text { Baseline } \\
\text { Unit }\end{array}$ & $\begin{array}{l}\text { PCM } \\
\text { Unit }\end{array}$ & Difference & $\begin{array}{l}\text { Baseline } \\
\text { Unit }\end{array}$ & $\begin{array}{l}\text { PCM } \\
\text { Unit }\end{array}$ & Difference \\
\hline APR & 155 & 278 & -123 & 279 & 274 & 5 & 269 & 280 & -11 \\
\hline JUL & 17 & 0 & 17 & 14 & 0 & 14 & 14 & 0 & 14 \\
\hline OCT & 88 & 56 & 32 & 92 & 67 & 25 & 117 & 103 & 14 \\
\hline FEB & 359 & 355 & 4 & 324 & 297 & 27 & 292 & 284 & 8 \\
\hline
\end{tabular}




\begin{tabular}{|l|r|r|r|r|r|r|r|r|r|}
\hline CHANGE & \multicolumn{9}{|c|}{ Number of hours with Operative temperatures $>26{ }^{\circ} \mathbf{C}$} \\
\hline \multirow{3}{*}{ Toronto } & \multicolumn{4}{|c|}{$\mathbf{8 0 \%}$} & \multicolumn{3}{|c|}{$\mathbf{6 0 \%}$} & \multicolumn{3}{c|}{$\mathbf{4 0 \%}$} \\
\cline { 2 - 11 } & $\begin{array}{l}\text { Baseline } \\
\text { Unit }\end{array}$ & $\begin{array}{l}\text { PCM } \\
\text { Unit }\end{array}$ & Difference & $\begin{array}{l}\text { Baseline } \\
\text { Unit }\end{array}$ & $\begin{array}{l}\text { PCM } \\
\text { Unit }\end{array}$ & Difference & $\begin{array}{l}\text { Baseline } \\
\text { Unit }\end{array}$ & $\begin{array}{l}\text { PCM } \\
\text { Unit }\end{array}$ & Difference \\
\hline APR & 41 & 0 & 41 & 5 & 0 & 5 & 0 & 0 & 0 \\
\hline JUL & 74 & 56 & 18 & 32 & 15 & 17 & 4 & 0 & 4 \\
\hline OCT & 111 & 63 & 48 & 78 & 20 & 58 & 38 & 0 & 38 \\
\hline FEB & 7 & 0 & 7 & 0 & 0 & 0 & 0 & 0 & 0 \\
\hline
\end{tabular}

\begin{tabular}{|l|r|r|r|r|r|r|r|r|r|}
\hline CHANGE & \multicolumn{9}{|c|}{ Number of hours with Operative temperatures $<21^{\circ} \mathbf{C}$} \\
\hline \multirow{3}{*}{ Vancouver } & \multicolumn{3}{|c|}{$\mathbf{8 0 \%}$} & \multicolumn{3}{c|}{$\mathbf{6 0 \%}$} & \multicolumn{3}{|c|}{$\mathbf{4 0 \%}$} \\
\cline { 2 - 11 } & $\begin{array}{l}\text { Baseline } \\
\text { Unit }\end{array}$ & $\begin{array}{l}\text { PCM } \\
\text { Unit }\end{array}$ & Difference & $\begin{array}{l}\text { Baseline } \\
\text { Unit }\end{array}$ & $\begin{array}{l}\text { PCM } \\
\text { Unit }\end{array}$ & Difference & $\begin{array}{l}\text { Baseline } \\
\text { Unit }\end{array}$ & $\begin{array}{l}\text { PCM } \\
\text { Unit }\end{array}$ & Difference \\
\hline APR & 155 & 143 & 12 & 180 & 176 & 4 & 235 & 231 & 4 \\
\hline JUL & 44 & 0 & 44 & 44 & 0 & 44 & 61 & 4 & 57 \\
\hline OCT & 151 & 80 & 71 & 136 & 94 & 42 & 141 & 114 & 27 \\
\hline FEB & 205 & 164 & 41 & 167 & 143 & 24 & 171 & 164 & 7 \\
\hline
\end{tabular}

\begin{tabular}{|l|r|r|r|r|r|r|r|r|r|}
\hline CHANGE & \multicolumn{9}{|c|}{ Number of hours with Operative temperatures $>\mathbf{2 6}{ }^{\circ} \mathbf{C}$} \\
\hline \multirow{3}{*}{ Vancouver } & \multicolumn{3}{|c|}{$\mathbf{8 0 \%}$} & \multicolumn{3}{|c|}{$\mathbf{6 0 \%}$} & \multicolumn{3}{|c|}{$\mathbf{4 0 \%}$} \\
\cline { 2 - 11 } & $\begin{array}{l}\text { Baseline } \\
\text { Unit }\end{array}$ & $\begin{array}{l}\text { PCM } \\
\text { Unit }\end{array}$ & Difference & $\begin{array}{l}\text { Baseline } \\
\text { Unit }\end{array}$ & $\begin{array}{l}\text { PCM } \\
\text { Unit }\end{array}$ & Difference & $\begin{array}{l}\text { Baseline } \\
\text { Unit }\end{array}$ & $\begin{array}{l}\text { PCM } \\
\text { Unit }\end{array}$ & Difference \\
\hline APR & 41 & 2 & 39 & 13 & 0 & 13 & 0 & 0 & 0 \\
\hline JUL & 2 & 0 & 2 & 0 & 0 & 0 & 0 & 0 & 0 \\
\hline OCT & 96 & 44 & 52 & 47 & 17 & 30 & 18 & 1 & 17 \\
\hline FEB & 56 & 15 & 41 & 27 & 2 & 25 & 5 & 0 & 5 \\
\hline
\end{tabular}

Table series 3. Extension of Figure 4.14 
Extension of Figure 4.21. Rate of energy saving compared to solar gain variations on July $3^{\text {rd }}$ and October $5^{\text {th }}$ in Vancouver.

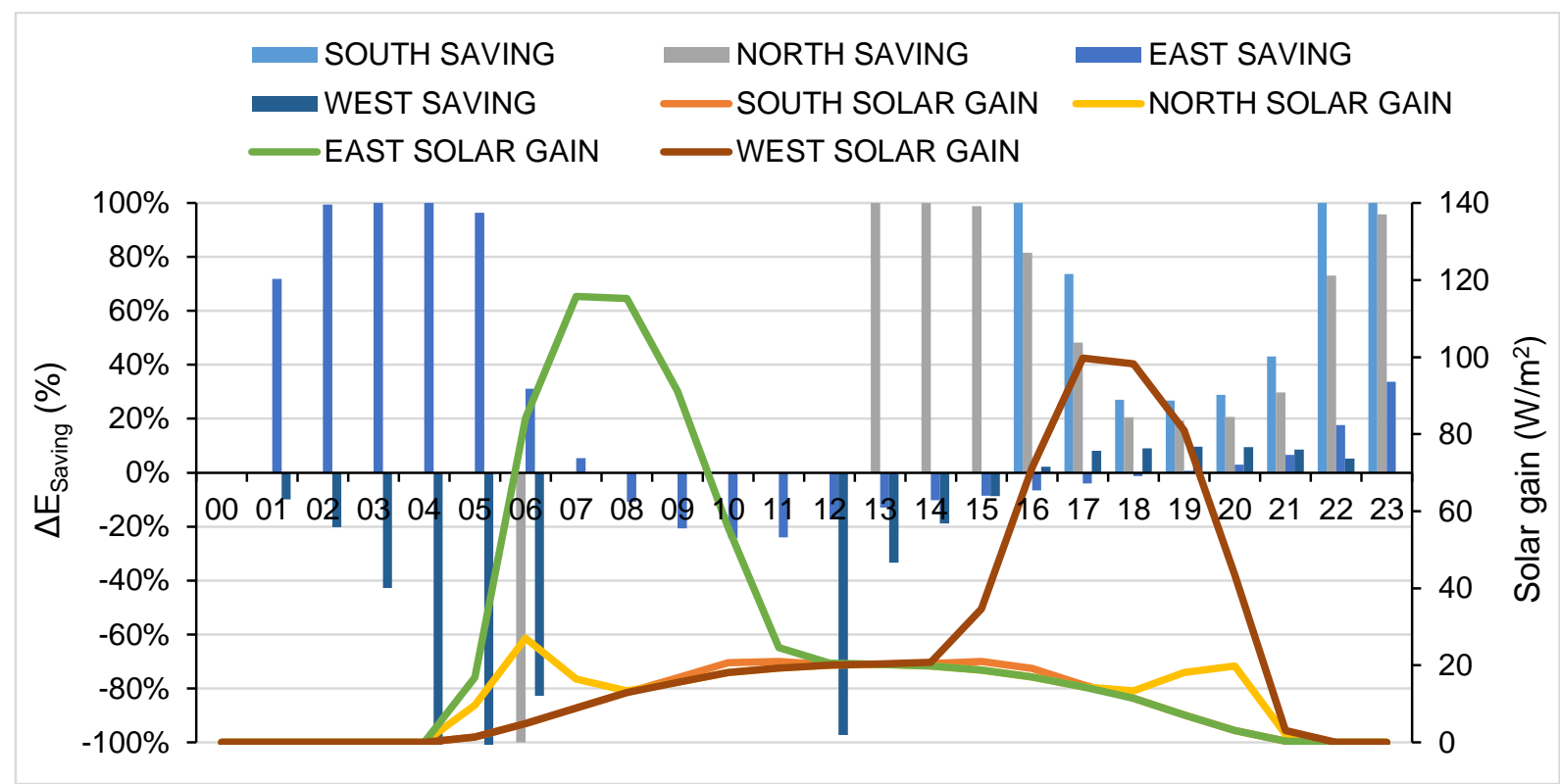

July $3^{\text {rd }}$

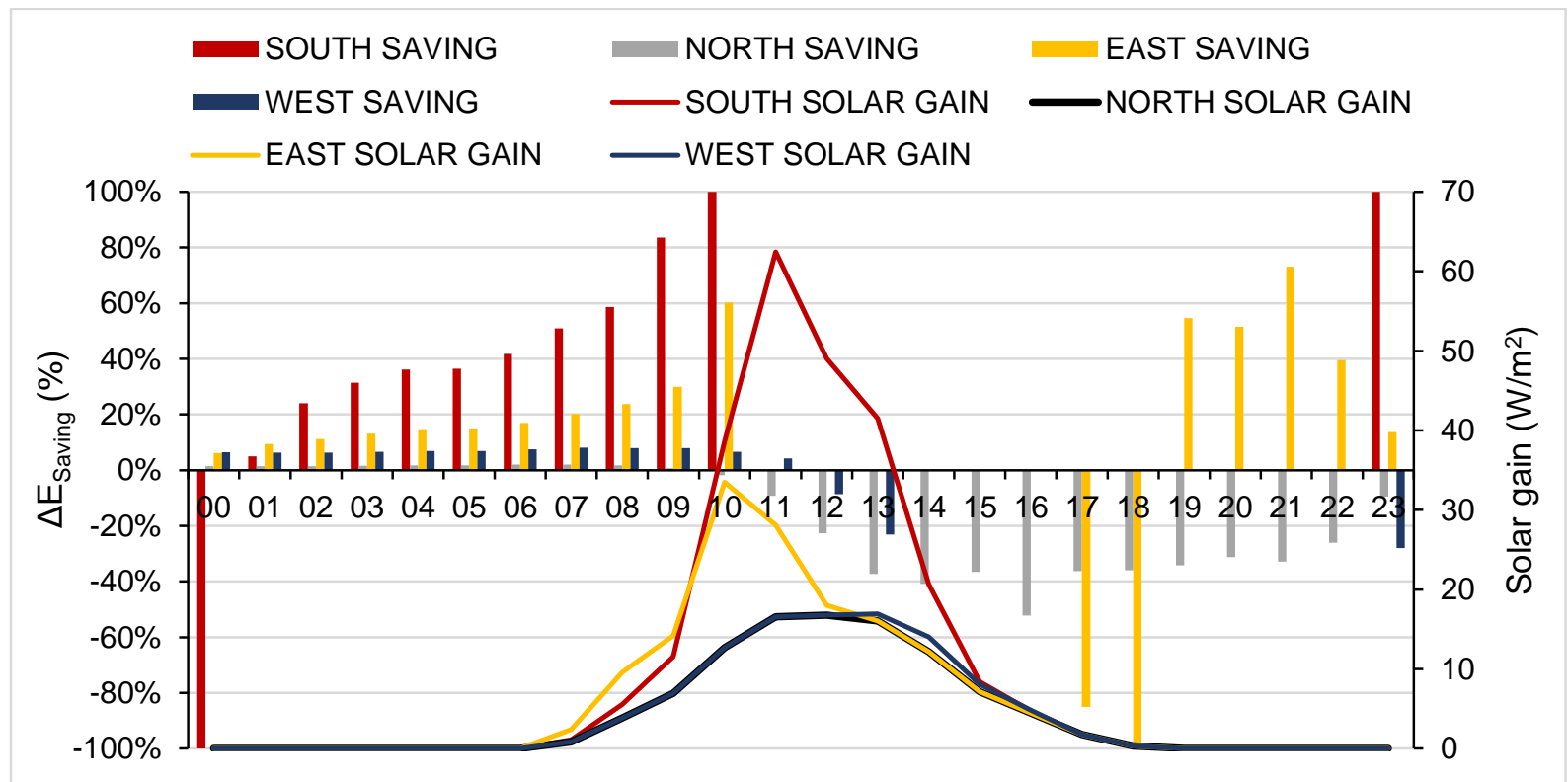

October $5^{\text {th }}$

Figure 1. Daily energy saving compared to solar gain variations 


\section{Simulation study \#5:}

Based on the results of simulation analysis, the amount of PCM in the space is linked with positioning of the PCM systems with regards to solar exposure. In addition, considering the melting range of the PCMs is also important as the position of PCMs in ceiling and walls show distinct behavior. The ceilings are better in reducing maximum temperatures and aborning heat while wall PCMs are necessary for shoulder seasons and winter.

It was shown that by increasing the number of PCM panels to interior partitions, better cooling and heating energy savings could occur. Ultimately, however, the justification of adding more PCMs is to observe the costs and weight of the entire system and compare them with the total savings. One option that could be studied in the future to address this issue further is to apply 1 layer of PCM with different melting points to surfaces.

As mentioned, a PCM layer with a higher melting point could be positioned on the ceiling while the PCM with lower melting point could be positioned on the walls. Many other combinations could be achieved to balance the weight, cost and performance of PCMs. This type of configuration to distribute the PCMs is a potential option to minimize the weight while maintaining the core concept of having two melting points in one zone. Another option is to adopt other PCM products for the composite PCM system with high latent heats. In this case, less surfaces would need to be covered while the heat storage capacity is increased.

\section{Appendix II: Experimental Tests Additions}

Presented below are additional images of the constructed test cells.

Figure 1. Additional images of the experimental test cell and composite PCM construction
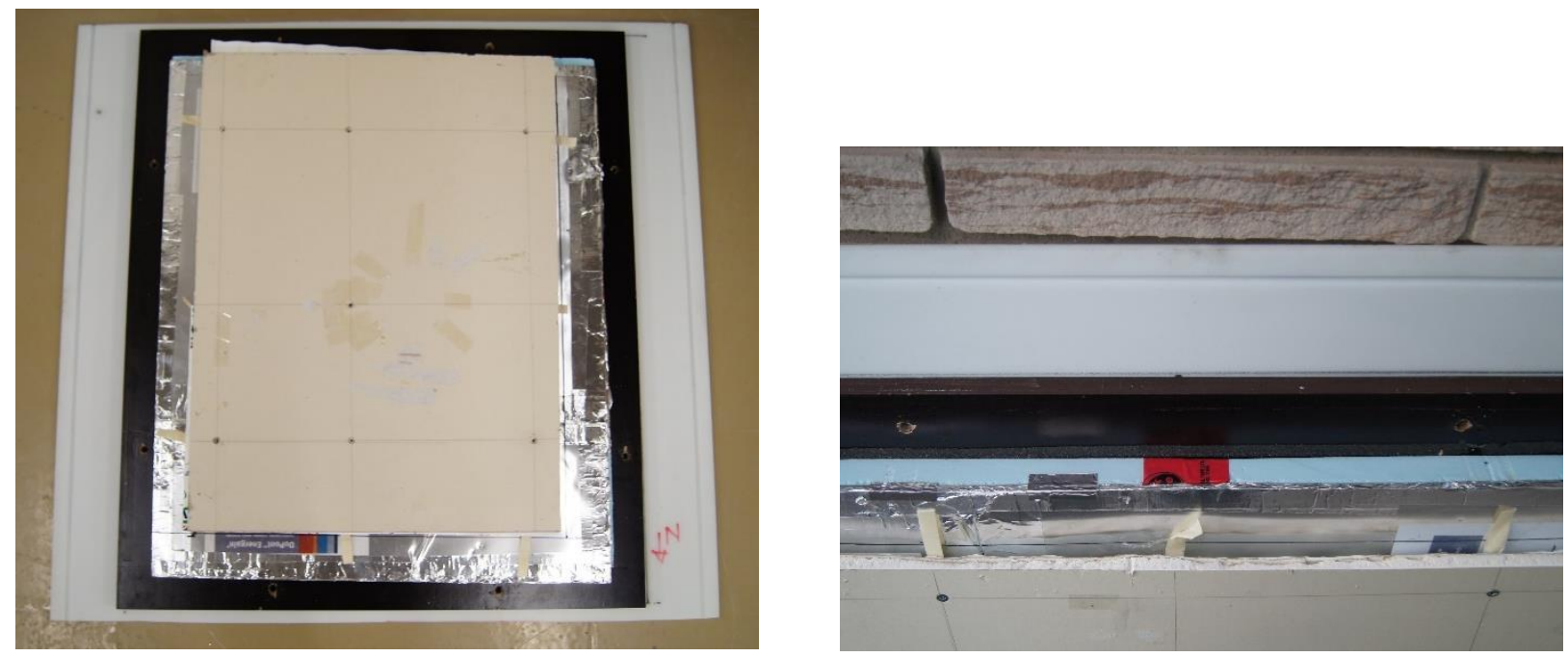

1) Ceiling structure of the composite PCM test cell 

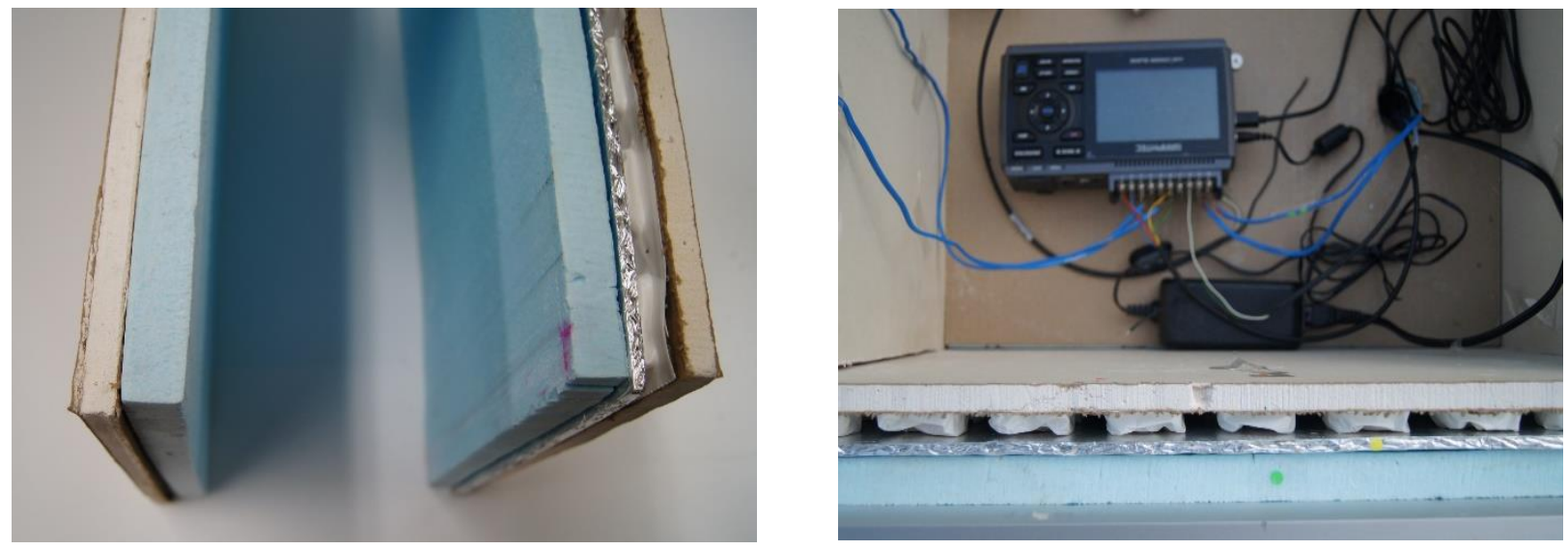

2) Wall assembly configuerations (Left) - Connection of sesnsors to the data logger (Right)
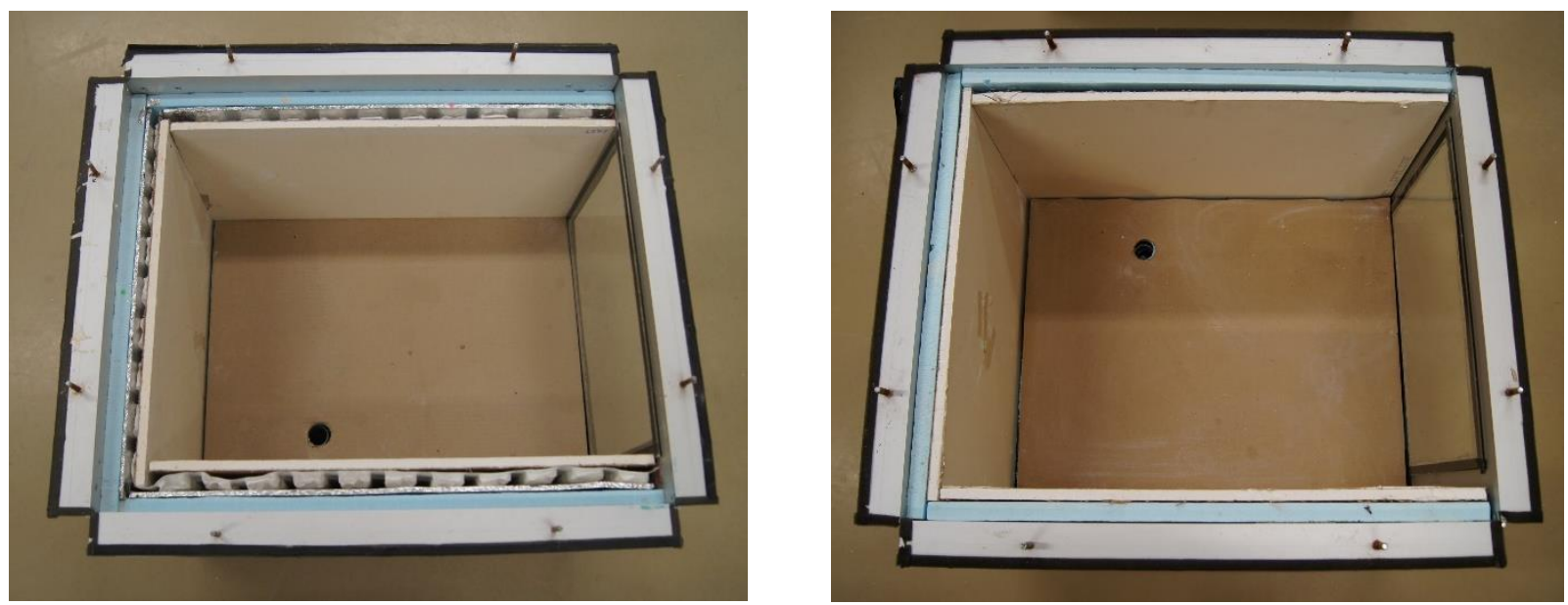

3) The composite PCM test cell (Left)- Reference test cell (Right) 
Table 1. Surface temperature variations with and without shading

\begin{tabular}{|c|c|c|c|c|c|c|c|c|}
\hline \multirow{2}{*}{ Categories } & \multicolumn{4}{|c|}{ Wall Surface Temperatures } & \multicolumn{3}{c|}{ Ceiling Surface Temperatures } \\
\cline { 2 - 9 } & Reference & $\begin{array}{c}\text { Shading } \\
\text { PCM }\end{array}$ & Reference & $\begin{array}{c}\text { Composite } \\
\text { PCM }\end{array}$ & Reference & $\begin{array}{c}\text { Composite } \\
\text { PCM }\end{array}$ & Reference & $\begin{array}{c}\text { Composite } \\
\text { PCM }\end{array}$ \\
\hline $\begin{array}{c}\text { Average } \\
\text { Temperatures } \\
\left({ }^{\circ} \mathrm{C}\right)\end{array}$ & 22.45 & 24.81 & 12.88 & 15.49 & 22.64 & 22.46 & 12.97 & 15.24 \\
\hline $\begin{array}{c}\text { Maximum } \\
\text { temperatures } \\
\left({ }^{\circ} \mathrm{C}\right)\end{array}$ & 35.22 & 31.04 & 31.56 & 25.50 & 36.67 & 30.91 & 33.10 & 25 \\
\hline $\begin{array}{c}\text { Minimum } \\
\text { temperatures } \\
\left({ }^{\circ} \mathrm{C}\right)\end{array}$ & 16.09 & 20.62 & 4.65 & 9.56 & 15.87 & 20.43 & 4.32 & 9.43 \\
\hline
\end{tabular}

A key result outlined earlier is the higher effectiveness of this composite PCM system is extreme temperatures. Table 2 shows the rate of change in the reference and the composite PCM test cell air temperature as the outdoor conditions change in three consecutive days in each month. For this analysis, temperature rise during the day from $6 \mathrm{am}$ to $6 \mathrm{pm}$, and temperature drop from $6 \mathrm{pm}$ to 6 am has been considered.

Table 2. Rate of change in outdoor air in relation to indoor test cell air temperature

\begin{tabular}{|l|c|c|c|c|c|c|}
\hline \multirow{2}{*}{} & \multicolumn{3}{|c|}{ Rate of temperature increase } & \multicolumn{3}{c|}{ Rate of temperature decrease } \\
\cline { 2 - 7 } & $\begin{array}{c}\text { Outdoor } \\
\text { Temperature } \\
\left({ }^{\circ} \mathrm{C}\right)\end{array}$ & $\begin{array}{c}\text { Reference } \\
\text { Cell } \mathrm{T}_{\text {Air }}\left({ }^{\circ} \mathrm{C}\right)\end{array}$ & $\begin{array}{c}\text { Composite } \\
\mathrm{PCM} \text { cell TAir } \\
\left({ }^{\circ} \mathrm{C}\right)\end{array}$ & $\begin{array}{c}\text { Outdoor } \\
\text { Temperatures } \\
\left({ }^{\circ} \mathrm{C}\right)\end{array}$ & $\begin{array}{c}\text { Reference } \\
\text { Cell } \mathrm{T}_{\text {Air }}\left({ }^{\circ} \mathrm{C}\right)\end{array}$ & $\begin{array}{c}\text { Composite PCM } \\
\text { Cell } \mathrm{T}_{\text {Air }}\left({ }^{\circ} \mathrm{C}\right)\end{array}$ \\
\hline July & $4.7^{\circ} \mathrm{C}$ & $9.9^{\circ} \mathrm{C}$ & $7.4^{\circ} \mathrm{C}$ & $-7.6^{\circ} \mathrm{C}$ & $-19.1^{\circ} \mathrm{C}$ & $-13.4^{\circ} \mathrm{C}$ \\
\hline August & $8.2^{\circ} \mathrm{C}$ & $10.6^{\circ} \mathrm{C}$ & $7.8^{\circ} \mathrm{C}$ & $-18.3^{\circ} \mathrm{C}$ & $-23.3^{\circ} \mathrm{C}$ & $-16.5^{\circ} \mathrm{C}$ \\
\hline September & $4.7^{\circ} \mathrm{C}$ & $6.2^{\circ} \mathrm{C}$ & $3.9^{\circ} \mathrm{C}$ & $-9.5^{\circ} \mathrm{C}$ & $-12.8^{\circ} \mathrm{C}$ & $-10.3^{\circ} \mathrm{C}$ \\
\hline October & $5.6^{\circ} \mathrm{C}$ & $7.6^{\circ} \mathrm{C}$ & $5.2^{\circ} \mathrm{C}$ & $-8.4^{\circ} \mathrm{C}$ & $-12.7^{\circ} \mathrm{C}$ & $-7.55^{\circ} \mathrm{C}$ \\
\hline
\end{tabular}

Temperatures start to rise in the morning noticeably from 6 am in all the months during the testing period. As evident from the table, rate of temperature increase in the composite PCM test cell is always lower than the temperature rise in the reference cell. The three days selected in August show an extreme temperature increase and decrease during the day, as shown in the table, on average in each day from 6 am to $6 \mathrm{pm}$, outdoor temperature is increased by $8.2^{\circ} \mathrm{C}$. The rate of increase in the reference test cell in the same period is $2.4^{\circ} \mathrm{C}$ higher than the outdoor temperature rise, in contrast to the composite PCM's air temperature which is increased by $0.4{ }^{\circ} \mathrm{C}$ lower than the outdoor temperature and $2.8^{\circ} \mathrm{C}$ below the rate in the reference cell. 
Overall the rate of increase in indoor cell temperatures was much higher in the month of July, while the lowest rate of temperature increase was experienced in the month of September.

A similar pattern is observed on the selected days from $6 \mathrm{pm}$ to 6 am when temperature drop during the night. Comparably, in July indoor cell temperature experience the highest rate of temperature decrease. With $7.6^{\circ} \mathrm{C}$ drop in outdoor temperatures, the reference test cell's temperature drops $11.3^{\circ} \mathrm{C}$ below this rate. The impact of PCM in regulating temperatures at night is shown to be positive in the three August days as the rate of temperature decrease is not as low as outside and is in fact $1.8^{\circ} \mathrm{C}$ higher. This fact points again to the better performance of the composite PCM system in extreme situations. 


\section{References}

Ahmed, T. (2012). Investigating the Impact of Thermal Mass Towards Energy Efficient Housing in Canada. Master's Thesis. Ryerson University, Toronto, Canada.

Almeida, F., Zhang, D., Fung, S, A., \& Wey, H, L. (2011). Comparison of corrective phase change material algorithm with ESP-r simulation. Proceedings from: $12^{\text {th }}$ Conference of International Building Performance Simulation Association, Sydney, Australia.

Alsaadani, S., Roque, M., Trinh, K., Fung, A., Straka, V. (2016). An overview of research projects investigating energy consumption in Multi-Unit Residential Buildings in Toronto. Proceedings from: The Asian Conference on Sustainability, Energy \& the Environment. Kobe, Japan.

Ascione, F., Bianco, N., De Masi, R. F., de' Rossi, F., Vanoli, G. P. (2014). Energy refurbishment of existing buildings through the use of phase change materials: Energy savings and indoor comfort in the cooling season. Applied Energy, 113, 990-1007.

American Society of Heating, Refrigeration and Air-conditioning Engineers (ASHRAE). (2013). ANSI/ASHRAE Standard 55-2013: Thermal Environmental Conditions for Human Occupancy. Ashrae, ASHRAE Sta, 58.

Athienitis, A. K., Liu, C., Hawes, D., Banu, D., Feldman, D. (1997). Investigation of the thermal performance of a passive solar test-room with wall latent heat storage. Building and Environment, 32(5), 405-410.

Baetens, R., Petter, B., Gustavsen, A. (2010). Phase change materials for building applications: A state-of-the-art review, 42, 1361-1368.

BASF, (2016). Climate control Micronal PCM. Retrieved from: http://www.micronal.de/portal/bast/ien/dt.jsp?setCursor=1_286688

Berardi, U. (2017). A cross-country comparison of the building energy consumptions and their trends. Resources, Conservation and Recycling. In press.

Berardi U, Manca M. (2017). The energy saving and indoor comfort improvements with latent thermal energy storage in building retrofits in Canada, Energy Procedia. 111, 462-471

Binkley, C., Touchie, M., Pressnail, K. (2012). Energy consumption trends of multi-unit residential buildings in the city of Toronto. Master's Thesis. University of Toronto. Retrieved from http://www.towerwise.ca/wp-content/uploads/2013/07/TAF-MURB-EnergyPerformance-Report-Phase-II.pdf

Bradshaw, V. (2006). Human comfort and health requirements. In, The Building Environment: Active and Passive Control Systems (Third, pp. 3-38). New York: John Wiley and Sons Ltd. 
Bruno, F., Belusko, M., Liu, M., Tay, N. H. S. (2015). 9 - Using solid-liquid phase change materials (PCMs) in thermal energy storage systems. (L. F. Cabeza, Ed.), Advances in Thermal Energy Storage Systems. (pp. 201-246). Woodehead Publishing Series in Energy

Canada Mortgage and Housing Corporation (CMHC). (2001). Healthy High-rise: A guide to innovation in the design and construction of high-rise residential buildings. Retrieved from: https://www03.cmhcschl.gc.ca/catalog/productDetail.cfm?cat=38\&itm=14\&lang=en\&sid=1vRr6lKmytEv6tgmb6 KLoqSdQLF3MDFbADkTZ5D3s1WFvgTupYVqbvzv6f9eyZRr\&fr=1489791210883

Cao, S., Gustavsen, A., Uvsløkk, S. (2010). The Effect of Wall-Integrated Phase Change Material Panels on the Indoor Air and Wall Temperature - Hot box Experiments. Zero Emission Buildings - Proceedings of Renewable Energy Conference 2010, 15, 15-26.

Cabeza, L. F., Barreneche, C., Martorell, I., Miro, L., Sari-Bey, S., Fois, M., ... Fernandez, A. I. (2015). Unconventional experimental technologies available for phase change materials (PCM) characterization. Part 1. Thermophysical properties. Renewable and Sustainable Energy Reviews, 43, 1399-1414.

Cabeza, L.F., and Mehling, H. (2008) Heat and Cold Storage with PCM: An Up to Date Introduction Into Basics and Applications. Springer. 95

Castell, A., \& Solé, C. (2015). Design of latent heat storage systems using phase change materials (PCMs). In L. F. Cabeza (Ed.), Advances in Thermal Energy Storage Systems (pp. 285-305). Woodhead Publishing Series.

Canadian Broadcasting Corporation (CBC). (2011). Throw-away buildings: Toronto's glass condos - Toronto - CBC News. Retrieved from http://www.cbc.ca/news/canada/toronto/throw-away-buildings-toronto-s-glass-condos1.1073319

Castellón, C., Nogués, M., Roca, J., Medrano, M., Cabeza, L.F. (2006). Microencapsulated phase changing materials (PCM) for building applications, in: L. Stiles (Ed.), Proceedings of the 10th International Conference on Thermal Energy Storage, Stockton, Yersey, pp. 1-9.

Cerón, I., Neila, J., \& Khayet, M. (2011). Experimental tile with phase change materials (PCM) for building use. Energy and Buildings, 43(8), 1869-1874.

Childs, K., Stovall, T. (2012). Potential Energy Savings Due to Phase Change Material in a Building Wall Assembly: An Examination of Two Climates. Prepared by Oak Ridge National Laboratory for the U.S. Department of Energy

Cianfrone, C., Roppel, P., Hardock, D. (2016). Holistic approach to achieving low-energy, highrise residential buildings. Journal of Building Physics, 522-41.

DesignBuilder (2016). DesignBuilder Software Ltd. Retrieved from: https://www.designbuilder.co.uk/ 
Di Turi, S., Stefanizzi, P. (2015). Energy analysis and refurbishment proposals for public housing in the city of Bari, Italy. Energy Policy, 79, 58-71.

Diaconu, B. M., \& Cruceru, M. (2010). Novel concept of composite phase change material wall system for year-round thermal energy savings. Energy and Buildings, 42(10), 1759-1772.

Entrop, A. G., Brouwers, H. J. H., Reinders, A. H. M. E. (2011). Experimental research on the use of micro-encapsulated Phase Change Materials to store solar energy in concrete floors and to save energy in Dutch houses. Solar Energy, 85(5), 1007-1020.

Evola, G., Marletta, L., Sicurella, F. (2014). Simulation of a ventilated cavity to enhance the effectiveness of PCM wallboards for summer thermal comfort in buildings. Energy and Buildings, 70, 480-489.

Favoino, F., Goia, F., Perino, M., Serra, V. (2014). Experimental assessment of the energy performance of an advanced responsive multifunctional facade module. Energy and Buildings, 68, 647-659.

Fiorito, F. (2014). Phase-change materials for indoor comfort improvement in lightweight buildings. A parametric analysis for Australian climates. Proceedings from: 2013 ISES Solar World Congress, Energy Procedia, 5, Mexico.

Fleischer, A. S. (2015). Fundamental Thermal Analysis. In Thermal Energy Storage using Phase Change Materials Fundamentals and Applications (Pages. 75-85). Springer.

Fraser, M. (2009). Increasing thermal mass in lightweight dwellings using phase change materials - a literature review, Built Environment Research Papers, 2(2), 69-83.

Gilbert, J., Koster, U. (2010). Phase Change Materials New thermal mass solution for low inertia buildings. Retrieved from http://www.energain.dupont.com

Government of Canada. (2016). Historical weather data. Retrieved on September 2016 from: http://climate.weather.gc.ca/historical_data/search_historic_data_e.html

Günther, E., Hiebler, S., Mehling, H., \& Redlich, R. (2009). Enthalpy of phase change materials as a function of temperature: Required accuracy and suitable measurement methods. International Journal of Thermophysics, 30(4), 1257-1269.

Guruprasad, A., Lin, Y., Liu, L., Fang, G. (2017). Synthesis, characterization and applications of microencapsulated phase change materials in thermal energy storage : A review. Energy and Buildings, 144, 276-294.

Hanam, B., Finch, G., Ricketts, D. (2014). Deep Energy Retrofits of High-Rise Multi-Unit Residential Buildings. ACEEE Summer Study on Energy Efficiency in Buildings, 109-120.

Heier, J., Bales, C., Martin, V. (2015). Combining thermal energy storage with buildings - A review. Renewable and Sustainable Energy Reviews, 42, 1305-1325. 
Heim, D., \& Wieprzkowicz, A. (2016). Positioning of an isothermal heat storage layer in a building wall exposed to the external environment. Journal of Building Performance Simulation, 9(5), 542-554.

Hoes, P., \& Hensen, J. L. M. (2016). The potential of lightweight low-energy houses with hybrid adaptable thermal storage: Comparing the performance of promising concepts. Energy and Buildings, 110(November), 79-93.

Jain, V., Garg, V., Mathur, J., \& Dhaka, S. (2011). Effect of operative temperature based thermostat control as compared to air temperature based control on energy consumption in highly glazed buildings. Proceedings from: 12th Conference of International Building Performance Simulation Association (pp. 14-16). Sydney, Australia.

Kaushik, B., Childs, P., Atchley, J. (2013). Field Testing of Low-Cost Bio-Based Phase Change Materials as Energy Storage Medium in Building Envelopes. Oak Ridge National Laboratory.

Kendrick, C., \& Walliman, N. (2007). Removing Unwanted Heat in Lightweight Buildings Using Phase Change Materials in Building Components: Simulation Modelling for PCM Plasterboard. Architectural Science Review, 50(3), 265-273.

Kenisarin, M., Mahkamov, K. (2005). Actual Problems in Using Phase-Change (pp. 1-36). Proceedings from: NATO ASI TESSEC, Cesme, Izmir, Turkey.

Kenisarin, M., Mahkamov, K. (2016). Passive thermal control in residential buildings using phase change materials. Renewable and Sustainable Energy Reviews, 55, 371-398.

Kesik, T., Saleff, I. (2009). Tower Renewal Guidelines: For the comprehensive retrofit of MultiUnit residential buildings in cold climates. Design. Daniels Faculty of Architecture, Landscape and Design, University of Toronto.

Kesik, T. (2011). The Glass Condo Conundrum. Report prepared for: University of Toronto, John H. Daniels Faculty of Architecture, Landscaping and Design. Retrieved from http://www.cbc.ca/toronto/features/condos/pdf/condo_conundrum.pdf

King, J. (DuPont). (2010). Hydrocarbon-based PCM Applications In Proceedings of: Thermal performance of the exterior envelopes of whole buildings XI international conference. Florida, USA.

Kosny, J., Yarbrough, D. W., Miller, A, W. (2007). Use of PCM Enhanced Insulation in the Building Envelope. Report to: Oak Ridge National Laboratory

Kosny, J., Stovall, T., Shrestha, S., Yarbrough, D. (2010). Theoretical and Experimental Thermal Performance Analysis of Complex Thermal Storage Membrane Containing BioBased Phase-Change Material (PCM). Thermal Performance of the Exterior Envelopes of Whole Buildings XI International Conference. 
Kosny, J., Kossecka, E., Brzezinski, A., Tleoubaev, A., Yarbrough, D. (2012). Dynamic thermal performance analysis of fiber insulations containing bio-based phase change materials (PCMs). Energy and Buildings, 52, 122-131.

Kosny, J., Shukla, N., Fallahi, A. (2013). Cost Analysis of Simple Phase Change MaterialEnhanced Building Envelopes in Southern U.S. climates. Prepared for U.S. Department of Energy.

Kośny, J., Kossecka, E. (2013). Understanding a potential for application of phase-change materials (PCMs) in building envelopes. ASHRAE Transactions, 119(PART 1), 3-13.

Kośny, J., Fallahi, A., Shukla, N., Kossecka, E., \& Ahbari, R. (2014). Thermal load mitigation and passive cooling in residential attics containing PCM-enhanced insulations. Solar Energy, 108, 164-177.

Kosny, J. (2015a). Overview of basic solid-liquid PCMs used in building envelopes - Packaging methods, encapsulation and thermal enhancement. In PCM-Enhanced Building Components (pp. 61-106). Springer.

Kosny, J. (2015b). Thermal and energy modelling of PCM-enhanced building envelopes. In PCM-Enhanced Building Components (pp. 167-223). Springer.

Kosny, J. (2015c). Examples of full-scale field experiments- Test huts and whole buildings containing PCM-enhanced envelope components. In PCM-Enhanced Building Components (pp. 143-167). Springer.

Kuznik, F., Virgone, J. (2009a). Experimental investigation of wallboard containing phase change material: Data for validation of numerical modeling. Energy and Buildings, 41(5), 561-570.

Kuznik, F., Virgone, J. (2009b). Experimental assessment of a phase change material for wall building use. Applied Energy, 86(10), 2038-2046.

Kuznik, F., David, D., Johannes, K., Roux, J. J. (2011). A review on phase change materials integrated in building walls. Renewable and Sustainable Energy Reviews, 15(1), 379-391.

Kuznik, F., Johannes, K., David, D. (2015). 13 - Integrating phase change materials (PCMs) in thermal energy storage systems for buildings. In Advances in Thermal Energy Storage Systems (pp. 325-353).

Kuznik, F., Johannes, K., Franquet, E., Zalewski, L., Gibout, S., Tittelein, P., ... Lassue, S. (2016). Impact of the enthalpy function on the simulation of a building with phase change material wall. Energy and Buildings, 126, 220-229.

Lee, K. O., Medina, M. A., Raith, E., Sun, X. (2015). Assessing the integration of a thin phase change material (PCM) layer in a residential building wall for heat transfer reduction and management. Applied Energy, 137, 699-706. 
Liddle, B., Lung, S. (2010). Age-structure, urbanization, and climate change in developed countries: Revisiting STIRPAT for disaggregated population and consumption-related environmental impacts. Population and Environment, 31(5), 317-343.

Liu, C. (1993). Thermal performance of a room with wall latent heat storage. Master Thesis, Concordia University, Canada.

McKeen, P., Fung, A. (2014). The Effect of Building Aspect Ratio on Energy Efficiency: A Case Study for Multi-Unit Residential Buildings in Canada. Buildings, 4(3), 336-354.

Muruganantham, K. (2010). Application of Phase Change Material in Buildings: Field data vs. Energy Plus Simulation. Master Thesis, Arizona State University, USA

Muruganantham, K., Phelan, P., Horwath, P., Ludlam, D., Mcdonald, T. (2010). Experimental investigation of a bio-based phase change material to improve building energy performance (pp. 1-6). In Proceedings of: ASME $20104^{\text {th }}$ International Conference on Energy Sustainability. Phoenix, Arizona, USA.

Narain, J., Jin, W., Ghandehari, M., Wilke, E., Shukla, N., Berardi, U., ... Van Dessel, S. (2016). Design and Application of Concrete Tiles Enhanced with Microencapsulated PhaseChange Material. Journal of Architectural Engineering, 22(1),

National Resources Canada (NRCan), (2016). Energy Efficiency Trends in Canada: 1990-2013. Retrieved from:

https://www.nrcan.gc.ca/sites/www.nrcan.gc.ca/files/energy/pdf/trends2013.pdf

Nikoofard, S., Ismet Ugursal, V., \& Beausoleil-Morrison, I. (2014). Technoeconomic assessment of the impact of window shading retrofits on the heating and cooling energy consumption and GHG emissions of the Canadian housing stock. Energy and Buildings, 69, 354-366.

Noren, A., Akander, E., Isfalt, E., \& Soderstrom, O. (1999). The effect of thermal inertia on energy requirements in a Swedish building-Results obtained with three calculation models. International Journal of Low Energy Sustainable Buildings, (1), 1-16.

Ozkan, A., Kesik, T., \& O'Brien, W. (2016). the Influence of Passive Measures on Building Energy Demands for Space Heating and Cooling in Multi-Unit Residential Buildings. In Proceedings of: eSim 2016 Building Performance Simulation Conference, Hamilton, Canada.

Pasupathy, A., Velraj, R., \& Seeniraj, R. V. (2008a). Phase change material-based building architecture for thermal management in residential and commercial establishments. Renewable and Sustainable Energy Reviews, 12(1), 39-64.

Pasupathy, A., Athanasius, L., Velraj, R., \& Seeniraj, R. V. (2008b). Experimental investigation and numerical simulation analysis on the thermal performance of a building roof incorporating phase change material (PCM) for thermal management. Applied Thermal Engineering, 28(5-6), 556-565. 
Pasupathy, A., \& Velraj, R. (2008). Effect of double layer phase change material in building roof for year round thermal management. Energy and Buildings, 40(3), 193-203.

Pedersen, C. O. (2007). Advanced zone simulation in EnergyPlus: Incorporation of variable properties and phase change material (PCM) capability. Building Simulation 2007, 13411345.

Phase Change Energy Solutions. (2016). Retrieved from: http://www.phasechange.com/

Pisello, A. L., Castaldo, V. L., \& Cotana, F. (2015). Dynamic thermal-energy performance analysis of a prototype building with integrated phase change materials. Proceedings of: $69^{\text {th }}$ Conference of the Italian Thermal Machines Engineering Association, ATI 2014, Milan, Italy, Energy Procedia, 81, 82-88.

RDH Building Engineering Ltd. (RDH). (2013). Air Leakage Control in Multi-Unit Residential Buildings. Prepared for Canada Mortgage and Housing Corporation (CMHC).

RDH Building Engineering Ltd. (RDH). (2012). Energy Consumption and Conservation in Midand High-Rise Residential Buildings in British Columbia. Report prepared for: CMHC, HPO BC housing, City of Vancouver, BC Hydro and Fortis BC.

Rodrigues, L., Sougkakis, V., Gillott, M. (2015). Investigating the potential of adding thermal mass to mitigate overheating in a super-insulated low-energy timber house. International Journal of Low-Carbon Technologies, 1-12.

Rodriguez-Ubinas, E., Arranz, B. A., Sánchez, S. V., González, F. J. N. (2013). Influence of the use of PCM drywall and the fenestration in building retrofitting. Energy and Buildings, 65, 464-476.

Schossig, P., Henning, H. M., Gschwander, S., Haussmann, T. (2005). Micro-encapsulated phase-change materials integrated into construction materials. Solar Energy Materials and Solar Cells, 89(2-3), 297-306.

Seong, Y. B., \& Lim, J. H. (2013). Energy saving potentials of phase change materials applied to lightweight building envelopes. Energies, 6(10), 5219-5230.

Sharma, A., Tyagi, V. V., Chen, C. R., Buddhi, D. (2009). Review on thermal energy storage with phase change materials and applications. Renewable and Sustainable Energy Reviews, 13(2), 318-345.

Shilei, L., Neng, Z., Guohui, F. (2006). Impact of phase change wall room on indoor thermal environment in winter. Energy and Buildings, 38(1), 18-24.

Shrestha, M. (2012). PCM Application-Effect on Energy Use and IA Temperature. Master's Thesis, Norwegian University of Science and Technology, Norway.

Shrestha, S., Miller, W., Stovall, T., Desjarlais, A., Childs, K., Porter, W., ... Coley, S. (2011). Modeling PCM-enhanced insulation system and benchmarking EnergyPlus against 
controlled field data. 12th Conference of International Building Performance Simulation Association, (2006), 14-16.

Shukla, N., Fallahi, A., Kosny, J. (2012). Performance characterization of PCM impregnated gypsum board for building applications. Energy Procedia, 30, 370-379.

Soares, N., Costa, J. J., Gaspar, A. R., Santos, P. (2013). Review of passive PCM latent heat thermal energy storage systems towards buildings' energy efficiency. Energy and Buildings, 59, 82-103.

Straube, J, F., Burnett, E. (2005). Building Science for Building Enclosure Design. Building Science Press. Westford, Massachusetts

Tabares-Velasco, P. C., Christensen, C., \& Bianchi, M. (2012b). Verification and validation of EnergyPlus phase change material model for opaque wall assemblies. Building and Environment, 54, 186-196.

Tabares-Velasco, P., Christensen, C., Bianchi, M., Booten, C. (2012a). Verification and Validation of EnergyPlus Conduction Finite Difference and Phase Change Material Models for Opaque Wall Assemblies. Building and Environment.

Tabares-Velasco, P. (2012d). Energy impacts of nonlinear behavior of PCM when applied into building envelope. ASME 2012 6th International Conference on Energy Sustainability \& 10th Fuel Cell Science, Engineering and Technology Conference San Diego, California

Talyor, R. A., Miner, M. (2014). A metric for characterizing the effectiveness of thermal mass in building materials. Applied Energy, 128, 156-163.

ThermaCool (2016.). GeoBlue ${ }^{\mathrm{TM}}$. Retrieved from: http://therma.cool/products/geoblue/

Touchie, M. F., Pressnail, K. D., Tzekova, E. S. (2014a). Energy Savings by Retrofitting MultiUnit Residential Buildings: Case Studies. In 3rd Building Enclosure Science and Techonology (BEST3) Conference. Atlanta, Georgia, USA.

Touchie, M. F., Pressnail, K. D., \& Tzekova, E. S. (2014b). Assessing Potential Energy Retrofits of Multi -Unit Residential Buildings in the Greater Toronto Area. Proceeding of: 14th Canadian Conference on Building Science and Technology (pp. 1-13). London, Ontario.

Tyagi, V. V., Buddhi, D. (2007). PCM thermal storage in buildings: A state of art. Renewable and Sustainable Energy Reviews, 11(6), 1146-1166.

Van Straaten, A, R., Straube, F, J., \& Lukachko, A, C. (2016). Increasing the durability and resilience of tall buildings with precast concrete enclosure systems. Proceedings from: Resilient Infrastructure. London, England.

Vautherot, M., Marechal, F., Farid, M. M. (2015). Analysis of energy requirements versus comfort levels for the integration of phase change materials in buildings. Journal of Building Engineering, 1, 53-62. 
Virgone, J., Noel, J., \& Residorf, R. (2009). Numerical Study of the Influence of the Thickness and Melting Point on the Effectiveness of Phase Change Materials: Application to the Renovation of a Low Inertia School. Proceedings of: Eleventh International IBPSA Conference (pp. 408-413). Glasgow, Scotland.

Zalba, B., Marin, J.M., Cabeza, L.F., Mehling, H. (2003). Review on thermal energy storage with phase change: materials, heat transfer analysis and applications, Appl. Therm. Eng. 23 (3) 251-283

Zhang, Y., Du, K., He, J. P., Yang, L., Li, Y. J. (2014). Impact Factors Analysis of the Enthalpy Method and the Effective Heat Capacity Method on the Transient Nonlinear Heat Transfer in Phase Change Materials (PCMs). Numerical Heat Transfer, Part A: Applications, 65(1), 66-83.

Zhu, N., Ma, Z., Wang, S. (2009). Dynamic characteristics and energy performance of buildings using phase change materials: A review. Energy Conversion and Management, 50(12), 3169-3181.

Ziskind, G. (2015). 12 - Modelling of heat transfer in phase change materials (PCMs) for thermal energy storage systems. (L. F. Cabeza, Ed.), Advances in Thermal Energy Storage Systems (pp. 325-353). Woodhead Publishing Series in Energy 